\title{
Városi területek megújítása - különös tekintettel a szabadterekre
}

\author{
doktori értekezés
}

Gábor Péter

Budapest 2013.

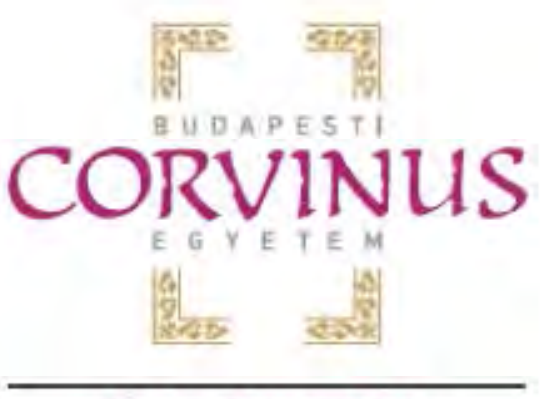

Tájépitészeti Kar 


\section{Budapesti Corvinus Egyetem \\ Élettudományi Területi Doktori Tanácsa}

Doktori Iskola:

Tudományág:

Szaktudomány:

Doktori Iskola vezető:

Témavezető:
Tájépítészeti és Tájökológiai Doktori Iskola

Agrármúszaki

Településépítészet, településrendezés

Dr. Csemez Attila

egyetemi tanár, tanszékvezető

Budapesti Corvinus Egyetem, Tájépítészeti Kar

Tájtervezési és Területfejlesztési Tanszék

Dr. Schneller István

egyetemi tanár, tanszékvezető

Budapesti Corvinus Egyetem, Tájépítészeti

Településépítészeti Tanszék

A jelölt a Budapesti Corvinus Egyetem Doktori Szabályzatában elöírt valamennyi feltételnek eleget tett, az értekezés mühelyvitájában elhangzott észrevételeket és javaslatokat az értekezés átdolgozásakor figyelembe vette, azért az értekezés nyilvános vitára bocsátható.

\section{ÜJ SZÉCHENYITERV}


A Budapesti Corvinus Egyetem Élettudományi Területi Doktori Tanácsának 2013. 12. 26-ki határozatában a nyilvános vita lefolytatására az alábbi bíráló Bizottságot jelölte ki:

Bíráló Bizottság:

EInök: $\quad$ Csemez Attila, DSc, BCE

Tagok: $\quad$ Alföldi György, DLA, BME

Gerzanics Annmária, CSc, ny.

Jámbor Imre, CSc, DLA, habil., BCE

Szirmai Viktória, DSc, habil., MTA, Szociológiai Kutatóintézet

Opponensek: Mezősné Szilágyi Kinga, CSc, habil.,BCE

Pallai Katalin, PhD, Nemzeti Közszolgálati Egyetem

Titkár: $\quad$ Balogh Péter István, PhD, DLA, BCE 


\section{Köszönetnyilvánítás}

A dolgozat nem jöhetett volna létre az interjúalanyaim;

Aczél Gábor, Alberch Ute, Alföldi György, Andaházy László, Andor Anikó, Bardóczi Sándor, Baross Pál, Berényi András, Berényi Mária, Cselovszky Zoltán, Csete Zoltán, Füle Gábor, Dr. Gerzanics Annamária, Gyulai István, Koszorú Lajos, Dr. Hajnal István, Magyar Mária, Dr. Nagy Béla, Nagy Elemér, Pados Gábor, Radványi Gábor, Dr. Sersliné Kócsi Margit, Dr. Schneller István, Schuchmann Péter, Szabó Ottó, Szakács Barnabás, Szloszjár Gyögy, Tóth Sándor, Török Noémi,

önzetlen segítsége nélkül. A dolgozat kutatási anyagának értékét, az Ö több évtizedes településfejlesztési, településrendezési szakmai tapasztalatuk, a fejlesztési projektekkel kapcsolatos közvetlen ismereteik alkotja, valamint az a szellemi munka, ahogy az egyes feltett kérdések kapcsán sokszor hosszas töprengés vagy hangos eszmefuttatás után adtak átgondolt válaszokat.

Segítségüket ezúton is köszönöm.

Köszönöm Radnóczi Péternek Budapest Főváros Főpolgármesteri Hivatal Városüzemeltetési Főosztály csoportvezetőjének, és Kövér Editnek a Főkert Zrt. Margitsziget Alközpontvezetőnek a stratégia tervek megvalósulásával kapcsolatos információkat.

Köszönöm dolgozatom mühelyvita verziója opponenseinek, Dr. M Szilágyi Kingának és Dr. Alföldi Györgynek, valamint témavezetőmnek Dr. Schneller Istvánnak a kritikai észrevételeit, melyek sokban segítették a dolgozat mühelyvitát követő továbbfejlesztését, a hiányosságok pótlását, a túlburjánzások visszametszését.

Köszönöm a munkahelyi vezetőmnek, Helembai Mihálynak, XIII. Kerületi Közszolgáltató Zrt. Közterületi Divízió vezetőjének, hogy kutatásom két intenzív utolsó évében támogatott.

Köszönettel tartozom továbbá BCE Tájépítészeti Karának valamint a TÁMOP-4.2.1/B-09/1/KMR2010-0005 programnak, melyek ösztöndíjjal segítették kutatásomat.

Gábor Péter 


\section{Tartalom}

Bevezetés, a téma jelentősége és a megoldandó feladat ................................................................................ 2

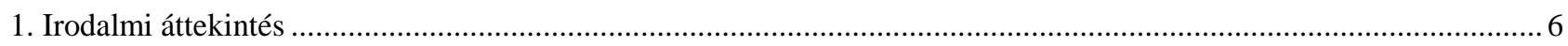

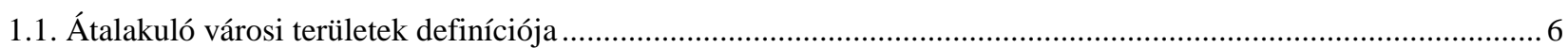

1.2. A városi területek megújulásának intézményi modelljei ..................................................................... 8

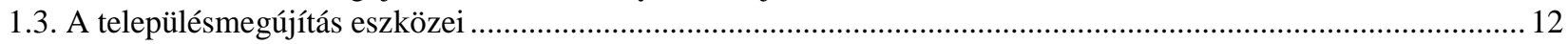

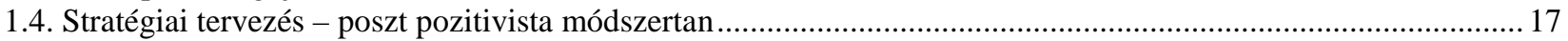

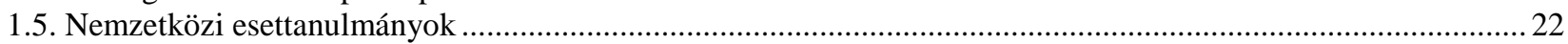

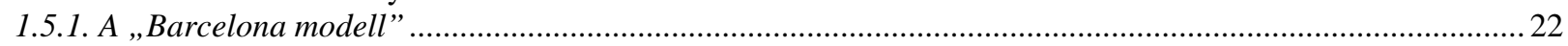

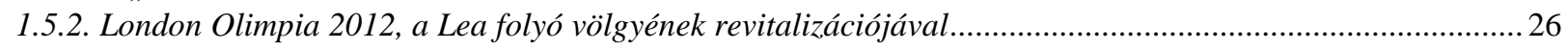

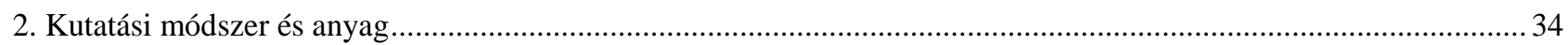

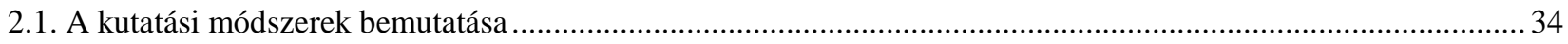

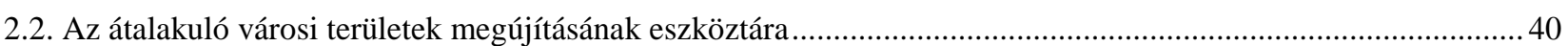

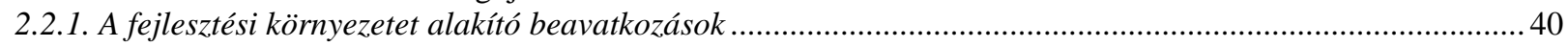

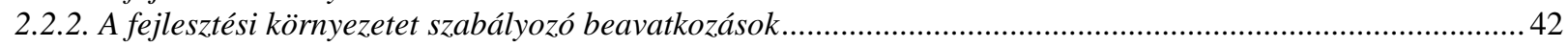

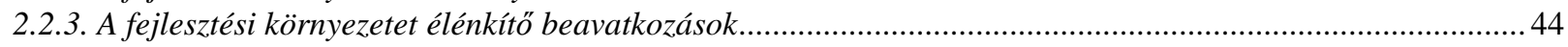

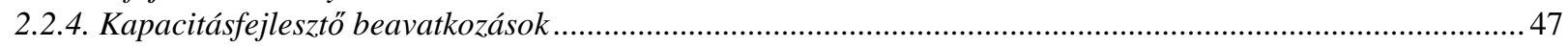

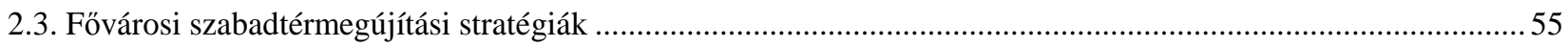

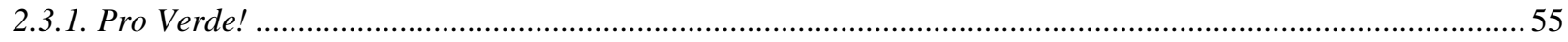

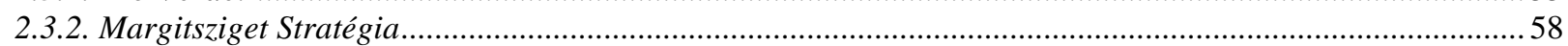

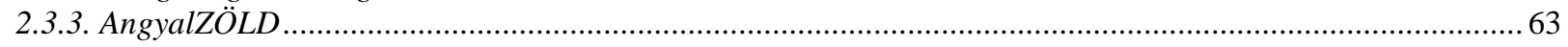

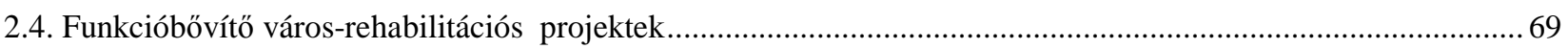

2.4.1. Budapest Szivve Program - Reprezentatív kaputérség kiépítése, I. ütem......................................................72

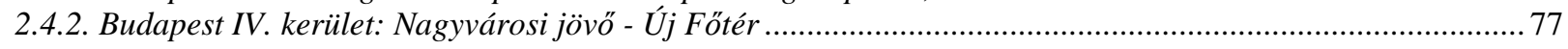

2.4.3. "Kultúra utcája" Budapest, Erzsébetváros funkcióbővítö rehabilitációja .................................................. 82

2.4.4. Budapest Európa Belvárosa Kulturális-gazdaság Fejlesztési Program, Józsefváros Palotanegyed..............88

2.4.5. Sashalom városközpont komplex városrehabilitációja ....................................................................... 94

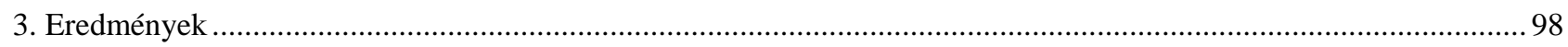

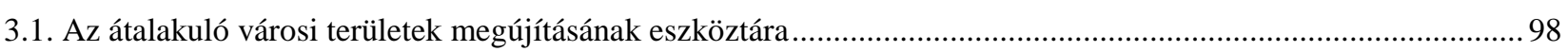

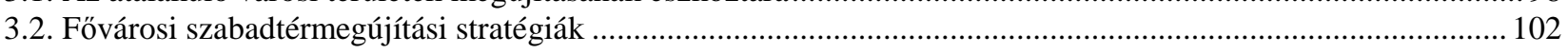

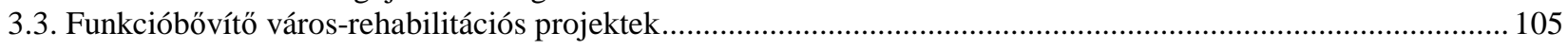

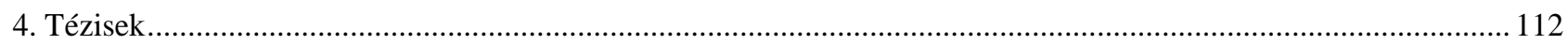

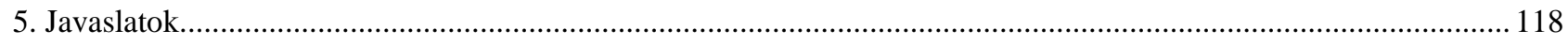

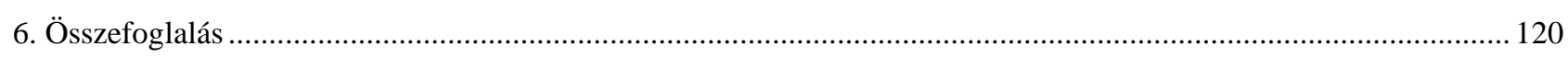

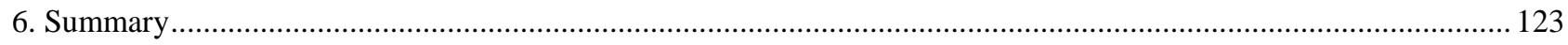

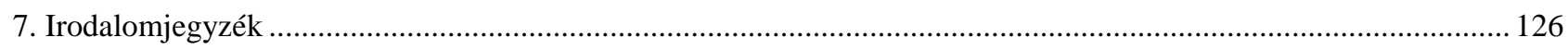

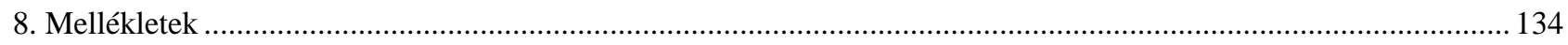

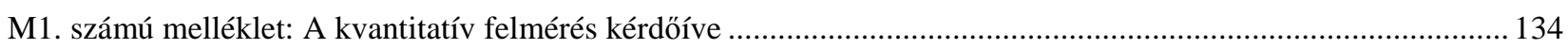

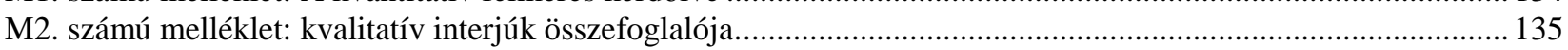

M3. számú melléklet: A szabadtérfejlesztési stratégiákban megfogalmazott projektek .......................................150

M4. számú melléklet: A vizsgált KMOP projektek akcióterületei ................................................................160

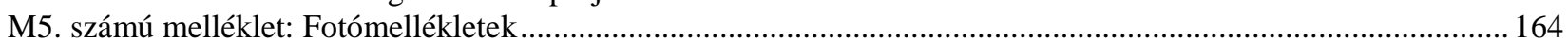




\section{Bevezetés, a téma jelentősége és a megoldandó feladat}

A dolgozat Budapest példáján keresztül vizsgálja a városi területek megújításának eszköztárát. A kutatás során az átalakuló városi területekre fókuszálok, hiszen Budapest esetében (is) ezek jelentős településfejlesztési kihívást és egyúttal lehetőséget jelentenek. A doktori iskola profiljához igazodóan kiemelt hangsúllyal vizsgálom a szabadterekkel kapcsolatos beavatkozásokat, közöttuik is a szabadtérépítészeti stratégiákat és az önkormányzati közterület megújítási projekteket.

„Európának erös és élhető városokra és városi régiókra van szüksége.” jelenti ki a Lipcsei Karta, az Európai Unió (EU) Tanácsának német elnöksége idején, 2007. májusában a miniszterek informális találkozóján kihirdetett dokumentumában. Ennek érdekében kiemelt feladatként jelöli meg a „kiváló minőségü közterületek létrehozását és fenntartását” az európai városok versenyképességének növelése céljából. A magas színvonalú építési kultúra mellett az élhető települési környezet létrehozatala és fenntartása jelenik meg követelményként a dokumentumban. A Karta hangsúlyozza, hogy az önkormányzatoknak kiemelt figyelmet kell fordítaniuk, a települési hatékonyság, az épített környezet minősége és a fenntarthatóság szempontjaira.

Az EU Tanácsának spanyol elnöksége alatt 2010. júniusában tartott informális miniszteri találkozón került megfogalmazásra a Toledói Dekrétum, mely több szempontból a Lipcsei Kartában foglaltak megerősítésének tekinthető. Alapvető célként az Európa 2020 Stratégia keretében intelligens, fenntartható és befogadó városfejlesztést tüz ki, és ennek részeként az integrált megközelítést, a település regenerációt ${ }^{1}$ és a fenntarthatóságot emelik ki. A dokumentum kijelenti, hogy a városias térségek $^{2}$ azok, melyekben a legjelentősebb kihívások, de ugyanakkor legnagyobb lehetőségek találhatók a versenyképes és élhető EUurópa megteremtése érdekében. Célként fogalmazza meg a dokumentum az elhagyott, használaton kívüli területek újrahasznosítását a városi szétterülés mérséklése érdekében. Feladatként jelenik meg a települési ${ }^{3}$ kutatások ösztönzése, összehasonlító elemzések és statisztikák készítése, a legjobb gyakorlatok bemutatása, az urbanizációs ismeretek terjesztése. A Toledói Dekrétum célja között szerepel „új városi szövetség” életre hívása az integrált település rehabilitáció segítése céljából. Ebben az újfajta szövetségben a városépítés folyamatában érintett valamennyi szereplő bevonása szükséges. Közülük a dokumentum az

\footnotetext{
${ }^{1}$ A dokumentum angol szövegében integrateed urban regeneration, míg a magyar fordításban integrált városfejlesztés szerepel , a szerző véleménye szerint hibásan.

${ }^{2}$ A dokumentum angol szövegében cities and towns kifejezés szerepel, míg a magyar fordításban ez városok-ként jelenik meg, a szerző véleménye szerint hibásan.

${ }^{3}$ A dokumentum angol szövegében urban topics kifejezés a magyar fordításban városi témákként szerepel, a szerző véleménye szerint hibásan.
} 
ingatlanfejlesztési és finanszírozási szektor, a helyi lakosság, önkormányzatok és az érintett szakmák képviselőit nevesíti.

Az Urbanisták Európai Tanácsa (European Council of Spatial Planners - Conseil Européen des Urbanistes) által 2003-ban elfogadott „Új athéni karta” elnevezésű jövőkép fogalmazza meg az európai urbanisztikai szakma hitvallását a településfejlesztés 21. századi céljait illetően. Az urbanisták lobbi anyagának is tekinthető dokumentum a településtervezésben résztvevő tervezők szerepkörének változására, kiszélesedésére hívja fel a figyelmet. A jövőben a tér-tervezőknek (spatial planners) kutatói, jövőkép meghatározói, objektum tervezői, politikai tanácsadói, mediátori és város menedzseri feladatokra egyaránt készen kell állniuk a dokumentum szerint. Ez a tervezői feladatok jelenleginél lényegesen szélesebb értelmezését jelenti.

Ezekkel az európai szintű urbanisztikai elhatározásokkal párhuzamosan a magyarországi urbanisztikai közbeszédben megjelentek a urbanisztikai paradigmaváltást szükségességét jelző vélemények. Ezen vélemények szerint, a szükülő külső gazdasági források és a gyorsuló társadalmi változások szükségessé teszik, hogy a településfejlesztés korábbi eszközrendszerét megújítsuk (Kuslits 2013: 7).

A fenti Európai Uniós, valamint urbanisztikai szakmai szempontokat figyelembe véve Budapest átalakuló városi területeit vizsgálva mutatom be és elemzem előbb a településmegújítás lehetséges teljes eszköztárát, majd konkrét esettanulmányokon keresztuil két, az élhető városi környezet megteremtésében fontos településfejlesztési eszközt; a zöldhálózat fejlesztési stratégiákat és az önkormányzati (részben) közterület megújítási projektek jelentőségét a településmegújításban. Ehhez az 1. fejezetben a releváns szakirodalom áttekintését végzem el, majd a 2. fejezetben a szakirodalom hasznosításával, saját kutatásaimat ismeretem.

Az 1.1. fejezetben az átalakuló városi területek fogalmát definiálom, ami az alulhasznosított városi területek értelmezésének a hazai és nemzetközi irodalomban való eltérése miatt indokolt. A dolgozat a fejezetben meghatározott definíció szerint értelmezi az átalakuló városi területek fogalmát. A kutatás hangsúlyos eleme a városi területek megújításának intézményi modelljeinek bemutatása, amire a 1.2. fejezetben kerül sor. Véleményem szerint az intézményi modellek a városrehabilitációs tervezési és kivitelezési folyamatok megértéséhez, a szereplők érték és érdekrendszerének elemzéséhez, a szereplők közötti interakciók feltárásához jelentős segítséget nyújtanak. A dolgozat ezeket az intézményi modelleket használva vizsgálja a későbbiek során a településmegújítás komplex eszköztárát, illetve elemzi a vizsgálatába vont stratégiákat és 
projekteket. A dolgozat 1.3. fejezetben tekintem át irodalmi források alapján átalakuló városi területek megújításának eszközeit. Az irodalmi kutatás a későbbi eszköz tipizáláshoz nyújt segítséget. Az 1.4. fejezetben a stratégia tervezés poszt-pozitivista módszertanát foglalom össze annak érdekében, hogy a kutatási rész a stratégiát vizsgáló kutatási egysége számára értékelési keretet biztosítson. Az 1.5. fejezetben két nemzetközi esettanulmányt mutatok be. A szabadtér rehabilitáció jelentősége kapcsán ikonikussá vált „Barcelona modell” a térségi fejlesztési stratégiákra épülő közterület megújítási projektek kapcsán releváns a kutatás számára. A londoni olimpia rehabilitációs beruházás pedig volumene, illetve frissessége mellett azért fontos, mivel arra példa, hogy egy barnamező megújítási projekt hangsúlya - átmeneti intenzív hasznosítást követően - hogyan tolódhat el a szabadtér megújítás, a zöldhálózati fejlesztés irányába.

A dolgozat második fejezetében kerül sor a kutatás során használt módszerek, majd az önálló kutatási egységek bemutatására.

A 2.2 fejezetben Budapestre fókuszálva áttekintem az átalakuló városi területek megújításának lehetséges állami és önkormányzati eszközeinek teljes tárát. Ehhez az 1.3. fejezetben bemutatott, Adams és társai által készített (Adams et al 2003: 53-59), majd Tiesdell és Allmendinger által továbbfejlesztett (Tiesdell \& Allmendinger 2005: 63-76) tipológiát használom és ültetem át budapesti környezetbe. A Toledói Dekrétumban megfogalmazott „új városi szövetség” jegyében a településmegújítási folyamatok bemutatásához a településmegújítási folyamatokat alakító szereplök széles spektrumának reprezentatív képviselöit vontam be vizsgálata látókörébe, megjelenítve közöttük az településrendezési, tájépítészeti tervezés, önkormányzati és államigazgatási szféra résztvevőin felül az ingatlanfejlesztői szakma képviselőit is. A kutatás 2.3. fejezetében a három települési szabadtérmegújítási stratégiák vizsgál, arra keresve választ, hogy az adott stratégiai tervek mennyiben voltak valóban hasznos eszközei a bennük megfogalmazott célok megvalósításának. ${ }^{4}$ A kutatás 2.4. fejezetében, önkormányzati beruházásként megvalósuló, részben szabadtér megújítási projekteket vizsgál. Név szerint az Új Magyarország Fejlesztési terv KözépMagyarországi Operatív Program (KMOP) keretében kiírt 5.5.2/B „Funkcióbővítő rehabilitáció, Budapesti integrált városfejlesztési program, Budapesti kerületi központok fejlesztés” pályázat keretében megvalósuló beruházások közül ötöt.

\footnotetext{
${ }^{4}$ Ez a kutatási rész az Élhető Települési Táj, BCE 2012. szerk. Jámbor Imre, Szilágyi Kinga, kiadványban került publikálásra. pp 175-192
} 
A dolgozat keretében az alábbi hipotéziseimet tesztelem:

Az hazai urbanisztikai gondolkodás paradigmaváltó korszakba érkezett. A korábbi

1. hipotézis pozitivista személet helyett a poszt-pozitivista megközelítés válik általánossá a XXI. század elsö évtizedének végétöl.

2. hipotézis A településfejlesztési stratégiák a településfejlesztés kulcsfontosságú eszközei.

A városi szabadterek megújítási projektek a városmegújítások fontos katalizáló

3. hipotézis elemei.

A településfejlesztési szabadtérépítészeti stratégiák céljainak megvalósítása akkor

4. hipotézis lehet hatékony, ha létezik vagy létrejön a megvalósításáért felelös operatív szervezet.

5. hipotézis $A$ fövárosi átalakuló területekhez kapcsolódó kerületközpont rehabilitációs pályázatokban döntö súllyal jelent meg a szabadtér rehabilitáció.

A KMOP funkcióbövitö pályázatok révén - a kiíró szándékával összhangban - az

6. hipotézis integrált városmenedzsment új szervezeti eszköze jött létre az érintett önkormányzatoknál. 


\section{Irodalmi áttekintés}

\section{1. Átalakuló városi területek definíciója}

Az MTA Regionális Kutatások Központjának a barnamezős területek megújulási esélyeit vizsgáló 2004-es publikációjában a barnamezős területek definíciója a következőképpen szerepel:

„A barnamezös terület kisebb hatékonysággal hasznosított (alulhasznosítottság), esetenként kiürült volt ipari terület. De ide soroljuk a rosszul hasznosított, vagy elhagyott vasúti és már kiürült katonai területeket is.” (Bartha 2004: 10)

Ugyan ebben a kiadványban, a rozsdaövezet a „modern ipari termelési korszak végén létrejött, nagyobb kiterjedésü, funkciójukat vesztett, részben vagy teljesen használaton kívüli ipari, gazdasági célú területeket. Ide sorolhatók azok a területek is, ahova olyan tevékenység települt, mely nem érdekelt, vagy nem képes a terület megújításában részt venni.” (Koszorú 2004: 326)

Angol irodalomban a barnamezős területeket ennél lényegesen átfogóbban definiálják. Az English Partnership $^{5}$ nemzeti barnamezős stratégiájában kijelenti, hogy nincs formális definíciója a barnamező fogalmának, sőt a fogalom használata félrevezető lehet. Ezért helyette a „korábban már beépített terület" (previously developed land PDL) kifejezést használja. A meghatározása szerint a PDL olyan:

„mely korábban be volt építve, vagy jelenleg is beépített állandó szerkezetekkel (ide nem értve a mezögazdasági vagy erdészeti építményeket) és az ezekhez kapcsolódó rögzített infrastruktúrával. A definíció az érintett terület környezetére is vonatkozik. A "korábban már beépített" terület elhelyezkedhet urbánus és rurális környezetben egyaránt. A definícióba bele tartoznak a honvédelem, bányászat, hulladéklerakás területei is ahol a terület rehabilitációja [restoration] nem valósult meg. A definíció kizárja a mezögazdasági és erdögazdaság használatban lévö építményeit, illetve az urbanizált területek korábban be nem épített területeit (parkok, rekreációs területek, kiskertek) ... , (English Partnership 2003:3-4)

\footnotetext{
${ }^{5}$ Az „English Partnership” Anglia település megújítási (regeneration) ügynöksége volt, mely regionális jelentőségű fejlesztésekkel foglalkozott a miniszterelnök helyettes (környezetvédelmi miniszter) megbízásából. 2008-tól szerepét az „Otthon és Közösség Ügynökség” (Homes and Communities Agency) vette át.
} 
A fenti definíció természetesen a közlekedési, vasúti területekre is vonatkozik, melyek ugyancsak korábban beépített területek. ${ }^{6}$ Timoty Dyxton a barnamezős területek rehabilitációjával foglalkozó cikkében jelzi, hogy Nagy-Britanniában a barnamező fogalma alatt a településpolitika a korábban már beépített területeket ért, belefoglalva ebbe az alulhasznosított és a használaton kívüli területeket, akár szennyezettek azok, akár nem. A barnamező megújítás jelentőségét a beépített területek további terjedésének mérséklésében, a zöldmezős beruházások elkerülésében határozza meg (Dixton 2007: 2381). A Richard Rodgers által vezetett Városi Akciócsoport jelentése a „Városi Reneszánszról” három kategóriát határoz meg a barnamezős területeken belül (Rodgers 1999: 178):

Lepusztult területek (derilict land): melyeket az ipari vagy egyéb hasznosítás oly mértékben károsított, hogy kármentesítés nélkül nem alkalmas újrahasznosításra.

Kihasználatlan területek (vacant land): Olyan jelenleg kihasználatlan területek, melyek kármentesítés nélkül újrahasznosíthatók.

Hasznosítatlan épületek (vacant buildings): Olyan használaton kívüli épületek, melyek szerkezetileg épek és elfogadható állapotban vannak.

Amerikában az US Environmental Protection Agency értelmezése szerint a barnamezőnek olyan területeket tekintenek jogszabályi definíció szerint, melyek újrahasznosítását környezeti szennyezés nehezíti. ${ }^{7}$ Németországban a barnamező definíciójaként olyan elhagyott területeket értelmeznek, melyek jellemzően települések belső részein találhatók, és környezeti vagy gazdasági kockázataik miatt el vannak zárva az újrahasznosítás elől (Frier 1998:4 quoted in Alker et al 2000:55). A Francia Környezetvédelmi Minisztérium definíciója szerint olyan terület, mely átmenetileg vagy tartósan elhagyott a rajta folyó tevékenység megszünését követően, és melynek az újrahasznosításához beavatkozás szükséges (Darmendrail 1999: 1 quoted in Alker et al 2000:55)

Alker és társai nemzetközi irodalmat áttekintő kutatásukban a barnamező fogalmával kapcsolatban jelzik, hogy az értelmezés nem egységes, a lepusztult, használaton kívüli, korábban beépített és szennyezett terület fogalma mentén definiált. Alkerék a tanulmányuk végén a következő definíciót adják a barnamezős területeknek: Barnamezös területnek számít minden olyan földrészlet vagy épület, mely korábban hasznositás alatt állt és jelenleg nincsen teljes mértékben hasznosítva, még akkor is, ha részleges hasznosítás alatt áll is. Ez lehet használaton kívüli, elpusztult vagy szennyezett terület. Ennek következtében a barnamezös területek nem alkalmasak beavatkozás nélkül, azonnali hasznosítására. (Alker et al 2000: 64)

\footnotetext{
${ }^{6}$ Itt a hazai településrendezési fogalom használat félrevezető lehet, ahol a közlekedési területek a beépítésre nem szánt területek közé tartoznak. Az angol definíció az építést nem csak az épület építésre értelmezi.

${ }^{7} \mathrm{http}: / /$ epa.gov/brownfields/overview/glossary.htm accessed on 2012-10-27
} 
A barnamezős területeket Doak és Karadimitiriou alulhasznosítottságuk alapján definiálja. Véleményük szerint a barnamezős területek ,olyan területek melyek a termelés és fogyasztás fö hálózataiból kikerültek és amelyek ennek következtében jelentös (szervezeti, pénzügyi) forrásokat igényelnek annak érdekében, hogy ismét piacképessé és a hálózatok számára hasonithatóvá váljanak.” (Karadimitriou 2007:37)

A fentiekből látható, hogy a barnamező fogalmának definíciója nem egzakt. A magyarországi értelmezés szükebb, a volt ipari területekre koncentráló, míg a nemzetközi meghatározás szélesebb körben, az alulhasznosítottságra és a beavatkozás szükségességére koncentrálnak.

Jelen dolgozatban az ,átalakuló települési területek” meghatározást a barnamezős területek szélesebb definíciójának szinonimájaként használom, alattuk azokat az építéssel érintett ${ }^{8}-$ akár közlekedési célú - területeket értve, melyek eredeti funkciójukat már nem, vagy csak részben töltik be, és átalakításuk, megújításuk a településfejlesztés vérkeringésébe való bekapcsolásuk állami/önkormányzati beavatkozást igényel.

Az eltérő megnevezés használatával célom a barnamező fogalmának Magyarországon elterjedt értelmezésétől való eltérés a hangsúlyozása.

\subsection{A városi területek megújulásának intézményi ${ }^{9}$ modelljei}

A városi területek megújításának gazdasági és társadalmi indítékait, az átalakulásokat elemző tanulmányokat Karadimitriou két kategóriába sorolja; az ingatlanpiaci értékeket alapul vevő (rent based) és a fejlesztési folyamatokat vizsgáló (development process) elemzésekre (Karadimitriou 2007: 44). Az előbbi csoportba tartoznak az urbanisztikai folyamatok gazdasági hátterét alapul vevő neo-klasszikus elméletek, melyek jellemzően befektetői szempontból elemzik makro szinten az ingatlanpiaci kereslet-kínálat alakulását és a piaci szabályozók ezekre való hatását. Ezen modellek értelmében egy terület hasznosításának módját végső soron a hasznosítás profit termelő képessége határozza meg, melynek a kifejeződése a bérleti díjfizetési képesség, vagyis az adott területhasználat által megtermelni képes bevétel. Egy településben megvalósuló területhasználati

\footnotetext{
${ }^{8}$ Az ,építéssel érintett” kifejezést itt az angol „,built up” kifejezés szinonimájaként használom. A kézenfekvő „,beépített területek” kifejezés a magyar településrendezésben használt „beépítésre szánt területek” kifejezés miatt lehet félrevezető. Az építéssel érintett területek tartalmazzák ugyanis a közlekedési területeket, melyeket a magyar nomenklatúra a „beépítésre nem szánt” területek közé sorol.

9 A dolgozatban az ,intézményi” kifejezést az institutional angol kifejezés fordításaként használom. Az kifejezés alternatívájaként még institucionalista kifejezés jöhet szóba, amit magyartalan hangzása miatt kerülök.
} 
szerkezetet a különböző területhasznosítási módok versenye határozza meg, mely révén minden területen az ott legmagasabb bérleti díjat termelni képes használat kap helyet (Ratcliff, 1949. quoted in Karadimitriou, 2007: 46).

Az urbanisztikai folyamatok piaci érték alapú megközelítésének kritikusai szerint a megközelítések alapvető gyengesége, hogy racionálisan, az információk teljességének birtokában döntő szereplöket feltételeznek, valamint azt, hogy az árak módosulása azonnal visszaállítja a piacon megjelenő egyensúlyi zavarokat. További problémája az elméleteknek, hogy az ingatlanfejlesztés folyamatát alapvetően problémamentes folyamatnak tekinti. (Van der Krabben 1993: 1383-34). Hodgson megítélése szerint a modellek hibái, hogy racionális, profit-maximalizáló tevékenységet tételeznek fel olyan szereplőktől, akiknek a prioritásai adottak és állandóak, akik törekszenek az egyensúlyi állapot elérésére, valamint rendelkeznek minden releváns piaci információval. (Hodgson 1999: 102 quoted in Adams et al 2005:20) Gore és Nicholson véleménye szerint a neo-klasszikus megközelítés több tényezőt is figyelmen kívül hagy (Gore \& Nicholson, 199: 705 quoted in Karadimitriou 2007:65):

- a különböző típusú keresletek közötti különbségek (használó vagy beruházó),

- a nem profit termelési célú, szociális vagy környezeti indíttatás,

- a várható haszonnal kapcsolatos bizonytalansági tényezők,

- az ingatlan értékbecslésének hatása az ingatlanárra,

- a folyamatban részt vevő szervezetek és intézmények komplex hálózatának a kölcsönhatásai a beruházás folyamán.

Az ingatlanpiaci értékeket vizsgáló kutatások hiányosságainak kiküszöbölése céljából jöttek létre az ingatlanfejlesztési folyamatokat vizsgáló, „intézményi urbanisztikai” tanulmányok. Az ezzel foglalkozó kutatók a társadalomtudományok eltérő - közgazdasági, urbanisztikai, szociológiai, politológiai - oldaláról közelítik meg a folyamatokat. Általános definícióként, az intézmény kifejezés alatt az urbanisztikai folyamatok ,játékszabályai” értendők. (Adams 2005: 39). Hodgson definíciója szerint az intézmények: „az egyéni szokások összességét jelentik, melyek, amennyiben mások által is vallottak és megerösítettek egy adott társadalmi közegben meghatározzák annak szocio-gazdasági intézményeit ... nem a formális szervezetek szüken értelmezett formájában, hanem a társadalmi viselkedési normák széles értelmezésében" (Hodgson 1997: 679 quoted in Tiesdell, Allmendinger 2005:61)

Healey szerint az urbanisztikai folyamatoknak intézményi megközelítése elengedhetetlen a folyamatok komplexitása miatt és azért, hogy érthetővé váljanak az egyes fejlesztések 
kulcsfontosságú elemei. (Healey 1992: 34-38) Healey értelmezésében az ingatlanfejlesztés nem más, mint: „egy terület és/vagy épület fizikai megjelenésének, a kapcsolódó jogoknak - anyagi és szimbolikus értékének - a megváltoztatása egy adott állapotból egy másikba. A folyamat résztvevöi a források megszerzésében és használatában érdekekkel és célokkal rendelkezö szereplök [agents], melyek szabályokhoz igazodnak, célokat és értékeket fogalmaznak meg és alkalmaznak.,,

Healey a definícióját ingatlan fejlesztésre használja, de megítélésem szerint ugyan ez a definíció a településfejlesztésre is alkalmazható, azzal a különbséggel, hogy a vizsgált szereplő itt az állam (önkormányzat) aki nem csak igazodik a szabályokhoz, de szabályozhat is. David Adams ${ }^{10}$ az állam feladatának és lehetőségeinek megfogalmazására használja az intézményi urbanisztikát. Megfogalmazásában „az intézmények politikai gazdaságtana” (political economy of institutionalism) az állam-piac viszonyának sokkal részletesebb elemzésére kínál lehetőséget, mint arra a föáramlati gazdasági elméletek képesek. (Adams 2005:45). A piaci folyamatokat szabályozó intézmények célja - miközben tükrözik az adott társadalom erőviszonyait - az, hogy biztonságot és stabilitást nyújtsanak a nem egyensúlyi, tökéletlen és irracionális gazdasági viszonyok között (Amin 2003: 366 quoted in Tiesdell, Allmendinger 2005:69).

Ball a brit szakirodalmat áttekintő munkájában az urbanisztika intézményi szemléletű kutatásairól három megközelítést különít el. Ezek között az első az általa az intézmények hatalmi szempontú megközelítése" (Power Approaches to Institutions) nevet viselö tanulmányok. Közös jellemzőjük, hogy ezekből hiányzik a tudatos módszertan, így inkább csak kiegészítői, mint helyettesítői lehetnek a gazdasági elemzéseknek. Három csoportot nevez meg ezen a kategórián belül:

a) Ad hoc intézményi elemzés (Ad hoc intitutional analysis): Ezek jellemzően valamilyen ingatlan, vagy szervezet történetét bemutató tanulmányok. Ezek az egyedi esetek alapján ad hoc magyarázatokkal szolgálnak konkrét urbanisztikai folyamatokra, fókuszuk inkább a szereplőkre, mint az átfogó gazdasági háttérre irányul.

b) Konfliktus intézményi elemzések (Conflict institutionalism): Ingatlanfejlesztési folyamatok során megjelenő konfliktusokat bemutató elemzések, melyek között gyakoriak egy adott helyi közösségi csoport és az ingatlanfejlesztő közötti konfliktust bemutató tanulmányok. Általánosságban megfigyelhető ezeknél az alacsony jövedelmi csoportok iránti elfogultság, ami nem meglepő annak fényében, hogy a szerzők sokszor ezeknek a csoportoknak a

\footnotetext{
${ }^{10}$ Prof. David Adams az University of Glasgow Property and Urban Studies elnöke, Research in Urban Studies igazgatója. Fő kutatási területe a várospolitika és regeneráció. Főbb publikációi Urban Planning and the Development Process (1994), Land for Industrial Development (1994), Greenfields, Brownfields and Housing Development (2002) Planning, Public Policy and Property Markets (2005) Urban Design in the Real Estate Development (2011). Shaping Places: Urban Planning, Design and Developmen (2012)
} 
szószólóik. Ugyancsak általános a konkrét események általánosításának, a tágabb környezet elemzésének hiánya.

c) Viselkedési intézményi elemzések (Behavioural institutionalims): A kutatások jellemzően egy adott ingatlantulajdonos, ingatlanfejlesztő, finanszírozó tevékenységét vizsgálva elemzik, hogy van-e valamilyen sajátos, a piaci bevétel maximalizálás általános érdekét felülíró jellegzetességük. Ezeknél a kutatásoknál is jellemző, hogy nem kellően alapos az adott szervezet és a piac többi szereplöjének az összevetése, az egyedi viselkedési preferenciák átfogó hatásainak bemutatása.

Ball elemzésének második csoportjába a struktúra-szervezet intézményi kutatások (Structure Agency Institutionalims) tartoznak, amely döntő részben Patsy Healey ${ }^{11}$ által kidolgozott ingatlanfejlesztés elemzési tematikát mutatja be. Struktúra alatt azok az anyagi erőforrások (tulajdon- és építési jog, munkaerő, finanszírozás, információ és tapasztalat), intézményi szabályok, és elképzelések értendők Healey szerint, amelyeket a folyamatot megvalósító ügynökségek elfogadnak. A folyamatban érintett szervezetek száma potenciálisan rendkívül nagy lehet, Healey ezeket (pl. ingatan értékbecslők, ingatlanfejlesztő társaságok, helyhatóságok) magától értetődőnek tekinti, így nem is nevesíti őket részletesen. (Healey 1992: 34-38) Healey négy lépést határoz meg a beruházási folyamat részletes elemzése során:

1. A folyamat, az események és a szervezetek részletes bemutatása;

2. A szervezetek szerepének és kapcsolatának bemutatása a fejlesztésben és az értékesítésben;

3. A résztvevők stratégiájának és érdekeinek elemzése, a folyamat kontextusának elemezése;

4. Átfogó kép megalkotása a folyamatról, tanulságok levonása.

Michael Ball a saját elméletét szintén kiemelten említi meg. A közel húsz éves kutatómunka során többször módosult intézményi elméletét az épület előállítás struktúráinak (Structures of Building Provision SoP) nevezi. (Ball 1998: 1513-1515):

Az intézményi urbanisztikai megközelítés azonban nem csak ingatlanfejlesztési beruházások leírására, hanem tervezési folyamatok részletes tanulmányozására is alkalmazható. Ennek egyik hazai példája Tosics Iván tanulmánya, amelyben a Budapest Városfejlesztési Koncepciója és Középtávú Városfejlesztési Programja kidolgozásának folyamatát mutatja be a résztvevő intézmények (tervező-megbízó) által képviselt célok-érdekek-értékek ütköztetésének és

\footnotetext{
${ }^{11}$ Prof. Patsy Healey a Newcastle Uinversity, School of Architecture, Planning and Lanscape professzor emeritusza. Kutatási témaköre a tervezés intézményi és szabályozói környezete. Főbb publikációi Re-enchanting democracy as a mode of governance (2012), Planning Theroy (2011), Making Better Places: the planning project in the 21st century.(2010), The treatment of space and place in the new strategic spatial planning in Europe. (2004) Planning, Governance and Spatial Strategy in Britain: an institutionalist analysis (Planning, Environment, Cities).(2000)
} 
egyeztetésének folyamataként. (Tosics 2004: 327-346). Ugyancsak intézményi megközelítést használ Pallai Katalin, amikor a stratégiai tervezési folyamatok kapcsán mutatja be, hogy az elméleti, lineáris tervezési folyamattal szemben milyen tervezési és újratervezési folyamatok valósultak meg az 1990-es évek Budapestjén. (Pallai 2010: 121-134)

A fentiekben leírt szakirodalmi források alapján használom a kutatási fejezetekben az intézményi urbanisztika eszközeit. A 2.2 fejezetben a Tiesdell és Allmendinger által kidolgozott ingatlanpiacot befolyásoló tervezési eszköz tipológiáját alkalmazom budapesti viszonyok között. A 2.3., 2.4. fejezetekben intézményi urbanisztikai modellel mutatom be a fővárosi szabadtérrehabilitációs stratégiák és funkcióbővítő rehabilitációs projektek megvalósulásának hátterét.

\subsection{A településmegújítás eszközei}

A településmegújítási állami és önkormányzati beavatkozások célja az épített környezet fizikai átalakításán túlmenően az adott területen érdekelt ingatlanfejlesztések egyéb szereplöi döntéseinek befolyásolása. Magyarországon a rendszerváltást megelőző időszakban a településmegújítás, -korszerüsítés, -átalakítás, -rekonstrukció kifejezésekkel leírt tevékenységeken ennél lényegesen szükebben definiált feladatot értett a szakirodalom. Faragó Kálmán Városrekonstrukció címü könyvében úgy definiálja a könyv tárgyát, hogy

„,beletartoznak mindazok a tervszerüen elöirányzott és végrehajtott müveletek, amelyek a városfejlödés által felvetett mennyiségi és minöségi követelmények kielégítését célozzák” (Faragó 1986: 9). Városrekonstrukcióval foglalkozva pedig „a tervezés és a megvalósítás számára egyidejüleg, egymással kölcsönhatásban kell irányelveket, utasításokat meghatározni.” (Faragó 1986: 11) A tervutasításokkal müködtetett, magán szektort nem ismerő szocialista rendszer logikájából következő definíció és feladat meghatározás jelzi; hogy a városrekonstrukció feladata a központosított tervezés keretében összehangolni valamint megvalósítani az építési beruházásokat. A tervezés az építési tevékenységek lebonyolításának megtervezését jelenti.

A rendszerváltást követően kialakuló piacgazdasági környezetben a magán beruházók aktív és meghatározó szereplőivé váltak a településfejlesztési folyamatoknak. A központosított állami tervezést kiszolgáló, szabályozás fókuszú urbanisztikai szakma gyakran a tervszerü fejlesztés és a spontán, beruházói tőke által diktált fejlesztések dialektikájával próbálta magyarázni a fővárosi urbanizációs folyamatokat.(Meggyesi 2005: 76). Meggyesi egész odáig megy, hogy a 
bevásárlóközpontok vonatkozásában a folyamatokat a jó és rossz harcaként írja le, ahol a „,a bevásárlóközpont valójában a mennyei Jeruzsálem diabolikus paródiája”. Schneller István is a város tudatos alakítása és a spontán fejlődés kettősségéről ír, azonban a városalakítás eszközei között már a városépítészeti keretszabályzat mellett a városrehabilitációs program, illetve a városfejlesztési koncepció eszközei is megjelennek. (Schneller 2004: 212) De a nyugat-európai irodalomban is megjelenik a piac vezette - tervezett fejlesztés dialektikája. Alexander éppen ezért hívja fel a figyelmet, hogy a tervszerü városfejlesztés és a piaci (spontán) ingatlanfejlesztés szembeállítása hibás megközelítés mely túlhaladott gazdasági elméleten alapszik. A kettő valójában egy egymástól el nem választható rendszer részeként müködik (Alexander 2001: 1). A korábbi dialektikus megközelítéssel szemben Tiesdell és Allmendinger a piaci folyamatokat ismerő tervezés (market aware planning) fontosságát hangsúlyozza. (Tiesdell, Allmendinger 2005: 56) Alexander véleménye szerint annak felismerése, hogy a tervezés nem egyenlő a közszféra beavatkozásaival, segítheti a tervezés-kutatást a piaci folyamatokat figyelembe vevő és azokat szabályozó eszközök kidolgozásában. (Alexander 2001: 17)

Szabó Julianna a tervezést és a szabályozást két olyan „társadalom-technikának” nevezi, melyek céljai nem fedik egymást. Definíciója értelmében a „A társadalmi szintü tervezés célja ... a jövő tudatos alakítása, amely feltételezi, hogy a tudatos alakítással egy - az adott értékrend szerint jobb eredmény érhetö el, mint pusztán 'kivárással', vagy a nem tudatosan a jövőre irányuló meggondolással.” (Szabó 2007: 57). Ez inverze a nem kívánatos folyamatok megakadályozását szolgáló szabályozásnak. A városirányítási rendszerek problematikáját - a magyarországi helyzetet elemző dolgozatában - abban látja, hogy az szétválasztja a rendezési és a fejlesztési eszközöket (Szabó 2007: 53).

A településregeneráció fogalma, tartalma és célja az urbanisztika különböző korszakaiban, eltérő földrajzi helyeken más és más tartalmat hordozott. Roberts és Sykes Nagy-Britannia urbanisztikai korszakai alapján kísérli meg a rekonstrukció, revitalizáció, megújítás, újjáépítés, regeneráció kifejezések differenciálását (Robert \& Sykes 2004:14). Ongjerth Richárd a városrehabilitációs tevékenységek ${ }^{12}$ Budapest korszakainak vonatozásában a három szakaszt különít el; az 1970-es évek végétől kibontakozó „kísérleti szakaszt”, az 1980-as években induló, a ferencvárosi rehabilitációkat megalapozó „folytatást” és a máig tartó „kiteljesedést”. (Ongjerth 2008: 21-26). A településmegújítási típusok szabatos definíciójával a magyar szakirodalom még adós, és furcsa bár magyar viszonyokra jellemző - módon erre jogszabály, az OTÉK (253/1997. [XII.20.] Korm.

\footnotetext{
${ }^{12}$ Ongjerth a városrehabilitáció alatt a korábbi városszerkezet, utcahálózatot lehetőség szerint megőrző, felújításra, „korszerüsítésre” fókuszáló tevékenységet ért (Ongjerth 2008:21)
} 
rendelet 2013.03.09-től hatályos verzió) 1. számú melléklete tesz - tudományosnak semmiképpen sem nevezhető - kísérletet: ${ }^{13}$

116. Település rehabilitáció: elavult, de értéket képviselö településrész, tömb olyan felújítása, amely során az úthálózat, az épületállomány és a növényzet erre érdemes elemeinek megtartásával, korszerüsítésével, az alkalmatlan épületek, épületrészek elbontásával, esetleg azok új épületekkel történö pótlásával történik az érintett terület értékeinek és minöségének a kornak megfelelö színvonalra emelése.

117. Település rekonstrukció: zömében elavult településrész olyan korszerüsítése, amelynél az épületek nagy része bontásra kerül, és szükség szerint az úthálózat és a tömbosztás is módosul a jelen igényszintnek megfelelö állapot elérése érdekében.

118. Település revitalizáció: a különösen értékes, elsősorban számos müemléki értékkel rendelkezö, elavult, élettelen településrész „újraélesztése” a történeti érték megtartásával, minimális kiegészítö, nagyrészt helyreállító beavatkozással, szükség szerint rendeltetésmódosítással.

Nagyon karakteres az eltérés a brit szakirodalmi és a magyar jogszabályi megközelítés között. Az előbbi az urbanisztikai korszakok eltérő paradigmáira, a település fejlesztés céljainak, eszközeinek változására kíván rávilágítani, míg az utóbbi pusztán az épület megújítás és az új építés aránya alapján differenciálva határozza meg a fogalmakat.

Több kutató is foglalkozik a közszféra ingatlanpiaci beavatkozási eszközeinek tipizálásával. A magyar szakirodalomban Lukovich Tamás adja meg a várostervezés egyik komplex eszközrendszerét. Lukovich szerint ezek az eszközök:

1. Totális városépitészet, amikor a városépítész a teljes együttes tervezése felett ellenőrzést gyakorol

2. Infrastruktúra tervezés: amikor a városépítész csak az épített környezet legmaradandóbb (!) elemeit, mint a fejlödés kereteit alakítja (utak, tömegközlekedés, közmürendszerek, közterületek, közparkok, közintézmények)

3. Szabályozók tervezése: amikor a városépítész indirekt módon különféle szabályozásokon keresztül formálja az építészek, mérnökök által tervezendö környezetet (tervezési

\footnotetext{
${ }^{13}$ A definíciók szerepeltetése az OTÉK-ban jogszabályi szempontból indokolatlan, hiszen a rendelet szövegében egyszer sem használja a fenti definíciókat. A jogszabály természetesen alkalmatlan arra, hogy a különböző építészet korszakok paradigmáit és településmegújítási megközelítés módját határozza meg a rehabilitáció, rekonstrukció, revitalizáció jelentését Mint jogalkotói kinyilatkoztatás a definíciók tudományos szempontból legalábbis megkérdőjelezhetőek. Véleményem szerint az OTÉK ezen passzusa már megalkotásakor is megérett a „rekonstrukcióra”.
} 
programok, megbízások, pályázati kiírások, tervezési útmutatók, különféle szabályzatok stb.) (Lukovich 2001: 76)

Csanádi és munkatársai a településrészek „slumosodását” vizsgálva vonják le azt a következtetést, hogy ez a városok spontán fejlődésének következménye, melyen „központi, hatósági beavatkozás révén lehet segíteni” (Csanádi et al 2010: 73). Ezeknek a városrehabilitációs beavatkozásoknak három csoportját különböztetik meg a szerzők:

- drasztikusabb, slum clearance típusö „dózeres”, dzsentrifikcióval járó,

- bontást és felújítást vegyesen alkalmazó, értékmegörző,

- komplexebb, csak kisebb felújításokat megvalósító, viszont kimondottan a lakosság megtartását célzó, szociális város-rehabilitációs beavatkozásokat.

Locsmándi Gábor a településtervezés három a fentiekkel összecsengő eszköztípusát különíti el (Locsmándi 1999: 145):

a) tervezési funkció, mely alatt a stratégiai és koncepcionális urbanisztikai tervezés szintjét érti

b) fejlesztési funkció, mely alatt a fejlesztési területek fejlesztésre való fizikai előkészítését határozza meg

c) rendezési funkció, ide a szabályozási eszközök tartoznak.

Adams, illetve később Tiesdell és Allmendinger az eszközöket abból a szemszögböl rendszerezi, hogy azok milyen hatással vannak a piaci szereplőkre. (Adams et ál 2003: 53-59, Tiesdell \& Allmendinger 2005: 63-76) Az eszközök tárát pedig kiegészítik a Nagy-Britanniában a 2004-évet követő építésügyi jogszabályváltozásokat követően megjelent új eszközökkel. (Ratcliffe et al 2009:46-49). Az ingatlanfejlesztésbe való beavatkozás eszközeit a tipológiák szintén négy fö kategóriába sorolják.

1. Piac alakító eszközök: Az ingatlanpiac kontextuális környezetének alakításával gyakorolnak hatást a beruházási környezetre. Ezek az eszközök alapvetően információ tartalmukkal befolyásolják a beruházókat, előre jelezve a közszféra vagy a piac más szereplőinek fejlesztési szándékait, fejlesztési igényeit és elképzeléseit.

2. Piac szabályozó eszközök: Az ingatlanpiaci folyamatok szabályozását és ellenőrzését célzó eszközök célja a közjavak fenntartásának, költségeinek, illetve a társadalmi szempontok beépítése a piaci tranzakciókba. Ezek az eszközök, egy adott területtel kapcsolatos építési jogok gyakorlását a tulajdonviszonyoktól függetlenül engedélyek adása, illetve megtagadása révén befolyásolják 
3. Piac élénkítő eszközök: A piac élénkítő eszközök az ingatlanpiaci szereplők aktivitásának növelését szolgálják bizonyos, az eszközkészítők által szükségesnek/hasznosnak ítélt célok elérése érdekében. Az élénkítést a piaci kereslet vagy a kínálat bővítésével érhetik el.

4. Kapacitásfejlesztő eszközök: Ezek az eszközök az ingatlanfejlesztési piac szereplőinek hatékony müködésének képességét növelik, információs források elérhetővé tételével, kapcsolati hálózatok kiépítésével, mobilizáció segítésével. Ezek az eszközök lehetnének a piac alakító, illetve az élénkítő eszközök részei is, azonban Tiesdell és Allmendinger inkább új csoportba sorolja őket. Az ebbe a csoportba tartozó eszközök közös jellemvonása, hogy a másik három eszközcsoport működését segítik elő.

A szerzők egy táblázatban foglalják össze a „tervezési eszközök” rendszerét és megemlítik az egyes típusokhoz tartozó jellemző példákat. A tipológiát készítők természetesen Nagy-Britannia tervezési gyakorlatából merítik példáikat, aminek a hazai szakmai gyakorlatban nem mindig található megfelelője. Az alábbiakban megkísérlem az egyes csoportokhoz tartozó példák „magyarítását”, a budapesti településfejlesztési gyakorlat analóg eszközeinek bemutatásával.

1. táblázat: Tervezési eszközök típusai (Adams et al. 2003: 64/ 4.1 táblázat alapján)

\begin{tabular}{|c|c|c|}
\hline $\begin{array}{c}\text { Tervezési eszközök } \\
\text { típusai }\end{array}$ & $\begin{array}{c}\text { Tipikus példa } \\
\text { Nagy-Britannia }\end{array}$ & $\begin{array}{c}\text { Tipikus példa } \\
\text { Budapest }\end{array}$ \\
\hline \multirow{3}{*}{$\begin{array}{l}\text { Piac alakítás } \\
\text { (a döntési környezet } \\
\text { és kontextus alakítása }\end{array}$} & $\begin{array}{c}\text { Infrastruktúra fejlesztési tervek, } \\
\text { programok }\end{array}$ & \multirow{3}{*}{$\begin{array}{c}\text { Települési jövőképek, koncepciók, } \\
\text { stratégiák }\end{array}$} \\
\hline & Fejlesztési tervek & \\
\hline & $\begin{array}{c}\text { Nem kötelezö érvényü tervek, } \\
\text { politikai elhatározások, stratégiák, } \\
\text { útmutatások }\end{array}$ & \\
\hline \multirow[t]{3}{*}{ Piac szabályozás } & \multirow[b]{2}{*}{ Állami építés szabályzás } & $\begin{array}{l}\text { Településrendezés, szabályozási } \\
\text { tervkészítés }\end{array}$ \\
\hline & & $\begin{array}{c}\text { Müemlékvédelmi, } \\
\text { természetvédelmi területek } \\
\text { kijelölése }\end{array}$ \\
\hline & $\begin{array}{c}\text { Telek értékesítéssel kapcsolatos } \\
\text { szerzödésekben történö } \\
\text { szabályozás }\end{array}$ & Településrendezési szerződések \\
\hline \multirow{7}{*}{$\begin{array}{l}\quad \text { Piac élénkítés } \\
\text { (a döntési környezet } \\
\text { kereteinek } \\
\text { módositása) }\end{array}$} & Állami támogatások & Pályázati támogatások \\
\hline & Adókedvezmények & Adókedvezmények \\
\hline & $\begin{array}{c}\text { Beruházást könnyítő szabályozási } \\
\text { eszközök }\end{array}$ & $\begin{array}{l}\text { Az építéshatósági engedélyezés } \\
\text { egyszerüsítése }\end{array}$ \\
\hline & Közúthálózati fejlesztések & $\begin{array}{l}\text { A terület megközelíthetőségét } \\
\text { javító beruházások }\end{array}$ \\
\hline & Közterületek fejlesztése & Közterületek megújítása \\
\hline & $\begin{array}{l}\text { Kisajátítással járó } \\
\text { ingatlanfejlesztések }\end{array}$ & $\begin{array}{c}\text { Állami, önkormányzati ingatlan } \\
\text { beruházások megvalósítása }\end{array}$ \\
\hline & Közös ingatlan-beruházások & PPP beruházások \\
\hline
\end{tabular}




\begin{tabular}{|l|c|c|}
\hline \multirow{2}{*}{$\begin{array}{l}\text { Kapacitásfejlesztés } \\
\text { (a szereplök }\end{array}$} & Kapcsolati háló fejlesztése & $\begin{array}{c}\text { Ingatlanpiaci információáramlás } \\
\text { segítése }\end{array}$ \\
\cline { 2 - 3 } $\begin{array}{l}\text { alkalmassá tétele a } \\
\text { legjobb megoldások } \\
\text { kidolgozására) }\end{array}$ & 'Társadalmi töke' & $\begin{array}{c}\text { Társadalmi konszenzusteremtés a } \\
\text { fejlesztési célokról }\end{array}$ \\
\cline { 2 - 3 } & A szakmai rutin kereteiböl való \\
'kitekintés' & $\begin{array}{c}\text { Megújítást koordináló szervezet } \\
\text { létrehozatala }\end{array}$ \\
\hline
\end{tabular}

A fenti tipológia megítélésem szerint jól használható a településfejlesztési, településrehabilitációs állami és önkormányzati beavatkozások teljes skálájának számbavételére. A dolgozat 2.2. fejezete ennek a tipológiának alapján rendszerezi és értékeli az urbanisztikai beavatkozások eszközrendszerét.

\subsection{Stratégiai tervezés - poszt pozitivista módszertan}

Az angolszász nyelvterületeken a stratégiainak nevezett tervezés az 1980-as évekig alapvetően az üzleti szektor tevékenységére korlátozódott, mely alól a honvédelmi stratégiák jelentettek egyedül kivételt. Az első kiadvány, ami a stratégiai tervezést a közszféra intézményei szempontjából értelmezte az J.B. Olsen és D.C Eadie 1982-es könyve „The Game Plan: Governance with Foresight” volt (Bryson 2004: 8). A stratégiai tervkészítés népszerü eszközzé vált a környezeti tervezés kapcsán. Segítségével meghatározhatja és ki is nyilváníthatja egy adott szervezet, hogy mi a viszonya a környezetéhez, hogyan kívánja céljait elérni. (Dale 2004: 15). A stratégiai tervezésnek ugyancsak feladata lehet a kommunikációk és a közösségi részvétel elősegítése, eltérő érdekek és értékek befogadása, bölcs és a lehetőségekhez mérten megfelelő információkon alapuló döntéshozatal elősegítése. Dale munkájában fejlesztési célú stratégiai tervezésről (Stragegic Planning for Development) beszél abban az esetben, amennyiben a stratégia olyan szervezetet érint, melynek célja a fejlesztés. Ezekben az esetekben a szervezet müködésének eredményességét annak alapján értékelhetjük, milyen mértékben képes befolyásolni az adott szempontból az életminőséget. (Dale 2004: 15). A stratégiai tervezés feladata lehet valamilyen közösségi tevékenység, közszolgáltatási funkció is. Ebben az esetben a feladat az, hogy a tervezést, a megvalósítást és a tanulságok közös levonását hogyan lehet eredményesen működtetni olyan környezetben, ahol egyik résztvevő sem kontrolálja a folyamatokat teljes mértékben, azonban sok szervezetet és egyént érint a tevékenységgel és sokaknak van ráhatása a folyamatokra. Egy ilyen megosztott hatalmi és felelősségi viszonyokban a stratégiai tervezés megvalósítása nehezebb feladat (Bryson 2004: 9). 
A Bryson szerint a stratégiai tervezés több hasznot is ígér a stratégiai készítője számára:

1. A stratégiai gondolkodás, cselekvés és tanulás elősegítése.

2. A döntéshozatal javítása, a döntések várható következményeinek számbavétele, a döntéshozatal koherens és védhető alapjainak megteremtése, a döntések koordinálása a különböző szervezeti szinteken keresztül.

3. A szervezeti müködés hatékonyságának javítása, a szervezeti müködés és menedzsment rendszer áttekintése, a feladatok világosabb meghatározása révén.

4. A szervezeten kívüli, társadalmi együttmüködési rendszer hatékonyságának növelése.

5. Az érintett szervezetek a stratégiai tervezés eredményeként demonstrálhatják, hogy milyen jelentős közösségi értéket teremt tevékenységük.

A stratégiatervezést általában, mint útvonal tervezését szokták modellezni, ahol a jelenlegi helyzet meghatározását, majd cél kitüzése követi a jövőkép és a küldetés segítségével. Ezt követően a stratégia alkotás és megvalósítás eszközeinek segítségével tudjuk a kitűzött pontok közötti távolságot áthidalni. (Bryson 2004: 9). Ennél a hagyományos diagram modellnél plasztikusabban szemlélteti a stratégai tervezés folyamatának bizonytalanságait és komplexitását az Adams és társai által, a tervezés ingatlanpiaci hatásait bemutató modellje.

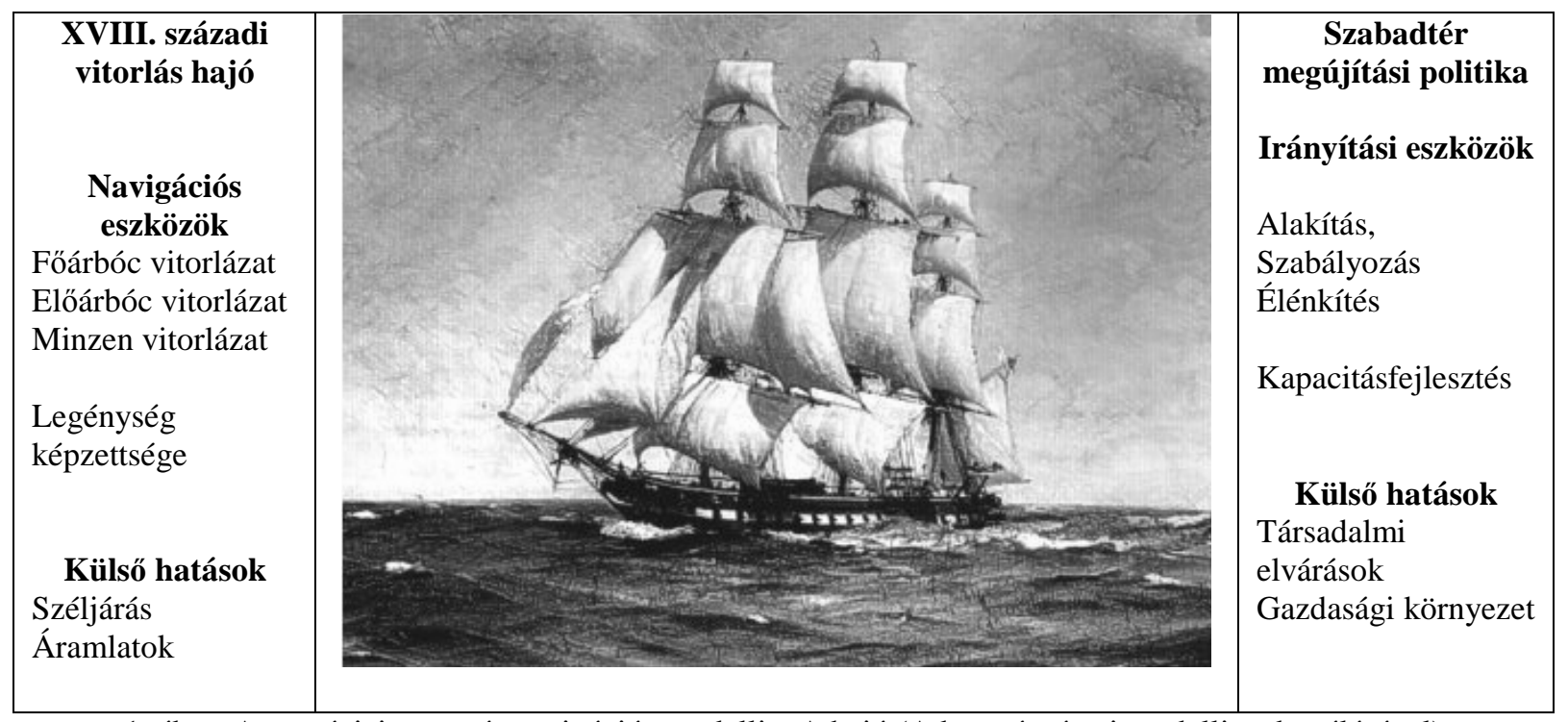

1. ábra: A stratégiai tervezés navigációs modellje. A hajó (Adams és társai modellje adaptálásával)

Ebben a fejlesztési környezetet egy XVIII. századi vitorlás hajóhoz hasonlítják. (Adams et al. 2003: 66). A modell megítélésem szerint adaptálható a települési szabadtér megújítási stratégiákra. Az adaptált modellben a hajó szimbolizálja a településpolitika rendszerét, mely vitorlázata segítségével (irányítási eszközök), az áramlatok és a széljárás (társadalmi elvárások és gazdasági környezet) figyelembevételével, illetve felhasználásával igyekszik kitüzött úti célja felé. 


\begin{tabular}{|c|c|c|}
\hline Navigáció & & $\begin{array}{l}\text { Szabadtér megújítási } \\
\text { stratégiaalkotás és } \\
\text { megvalósítás }\end{array}$ \\
\hline $\begin{array}{l}\text { Indulás helyének } \\
\text { idejének (A) megjelölése }\end{array}$ & & Helyzet meghatározás \\
\hline Úti cél kitűzése (B) & se & Jövőkép meghatározás \\
\hline Útvonal tervezése & & $\begin{array}{l}\text { Intézkedések } \\
\text { megtervezése, }\end{array}$ \\
\hline Utasítások kiadása & & $\begin{array}{l}\text { Programok, projektek } \\
\text { megvalósítása }\end{array}$ \\
\hline $\begin{array}{l}\text { Rendszeres helyzet- } \\
\text { meghatározás }\end{array}$ & & Monitoring \\
\hline Szereplők & 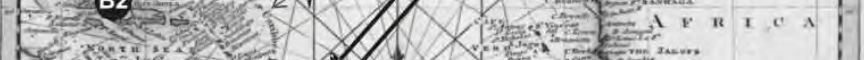 & Szereplők \\
\hline Utasok & & Lakosok, választó polg. \\
\hline Tulajdonos & 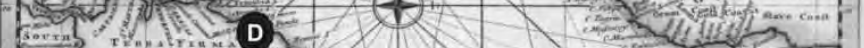 & Politikai döntéshozó \\
\hline Kapitány & 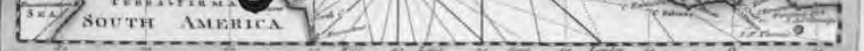 & Menedzsment szervezet \\
\hline Legénység & & Operatív irányítók \\
\hline Navigátor & & Szakértő/tervező \\
\hline Rakomány & & $\begin{array}{l}\text { Zöldhálózat, zöldfelületi } \\
\text { rendszer }\end{array}$ \\
\hline
\end{tabular}

2. ábra: A stratégiai tervezés navigációs modellje: Navigáció (Adams és társai modelljének adaptálásával)

A cél meghatározását a hajó tulajdonosa (politikai döntéshozó) végzi figyelembe véve az utasok (lakosság, választópolgárok) igényeit, illetve a rakomány (települési zöldhálózat) jellegét. A XVIII. századi térképészet pontatlansága miatt a cél (jövőkép) csak hozzávetőlegesen határozható meg. A célhoz vezető útvonal a változó külső körülmények (gazdasági, társadalmi környezet) nem egyenes vonalú. A hajózás során a rendszeresen végzet navigáció (monitoring) segíthet annak megállapításában, hogy a vitorlázatunk beállításai (irányítási eszközeink) a kitüzött cél irányába viszi-e hajónkat. A hajó kapitányának (menedzsment szervezet) feladata, hogy a navigátor (szakértő/tervező) helyzet meghatározása alapján, a külső körülmények felmérésével megfelelő utasítást adjon a legénységnek (operatív irányítók, végrehajtók). Mennél viharosabbak a külső körülmények, annál fontosabb a kapitány és a legénység képzettsége a hajó irányban tartásához. Ha a kapitány képzetlen, a jó legénység nem tudja helyette irányítani a hajót. Amennyiben a legénység képzetlen, akkor a kapitányi parancsok nem megfelelő módon vagy időben érvényesülnek és a hajó eltér ideális útvonaláról. Érdekes gondolatmenete Adams és társainak, hogy a hajó rossz kapitányi döntések és alkalmatlan legénység mellett is elérheti úti célját szerencsés széljárás és áramlatok esetén. Bár ugyan ezek a széljárások és áramlatok zátonyra is sodorhatják a hajót.

A fenti modell szemléletesen mutatja be a stratégiai tervezés poszt-pozitivista módszertanát, ahol az A-ból, B-be vezető út kijelölésekor tisztában vagyunk vele, hogy útvonalunkat - a tölünk független körülmények illetve intézkedéseink nem kalkulált hatásai miatt - nem tudjuk előre pontosan 
meghatározni. Tisztában vagyunk azzal, hogy intézkedéseink eredményeit, a változó külső körülményeket folyamatosan figyelnünk, azokhoz alkalmazkodnunk kell, sőt az is várható, hogy végső célunk elér az eredetileg kijelölttől.

Mára a stratégia tervezés bevett gyakorlattá vált a non profit szervezetek körében is. NyugatEurópában ma már sok szervezet van túl a költség-haszon elemzések, tervezés-programozásköltségelés, célokhoz rendelt menedzsment, folyamatos megújítás és ki tudja hány egyéb már-már bevettnek tekinthető technika alkalmazásával készült tervezési folyamaton. És sok szervezet vezetője volt már tanúja annak, hogy hogyan fogy el a tervezési folyamat során a kezdeti lendület. Ebböl a szempontból a magyarországi tervezési gyakorlat kezdi utolérni nyugati társait. Magyarországi településtervezési gyakorlatban a „Stratégia terv” kifejezése az Integrált Városfejlesztési Stratégia fogalmának kormányzati bevezetését követően, a minisztériumi kézikönyv „útmutatásainak” figyelembevételével vált általánossá. (NFGM 2009: 4), olyannyira, hogy ma már, Integrált Településfejlesztési Stratégia néven az építési törvény alapján a településrendezés és -fejlesztés tervezésének kötelező elemévé vált (314/2012.[XI.8.] Kor. rendelet $\S 6-\S 7)$.

Allisson és Kahye felhívja a figyelmet, hogy a stratégiai tervezés nem egy jól kiszámítható lineáris folyamat. Arra sem alkalmas, a jövőt megjósolja, hiszen olyan témakörökkel foglalkozik, melyek jellemzően konfliktust okoznak a különböző érdekcsoportok között, és olyan helyzetekkel, ahol több lehetséges jó (és még több rossz) megoldás létezik. A folyamat lényege éppen a meglévő konfliktusoknak a feloldása olyan döntésekkel, melyek, ha teljes konszenzust nem is teremthetnek, de elfogadhatóak a felek számára. (Allison \& Kahye 2005: 4) Pallai Katalin véleménye szerint DélKelet-Európában a stratégiai tervezés egyik fontos feladata a korábbi település menedzsment gyakorlatának felváltása olyan rendszerrel, mely „segíti az információn alapuló, átlátható és hatékony döntéshozatalt”. Budapest Városfejlesztési Koncepciójának 1991-2001 közötti alakításának tanulságai alapján, a kiszámítható és megbízható együttmüködés kialakítását tartja a stratégiai tervezés egyik kulcselemének. (Pallai 2008: 7). Ennek alapján a fejlesztési stratégiaalkotás a közösségi tervezés egyik formája, és így a poszt pozitivista tervezéselméletek közé sorolható (Allmendinger 2002: 16). A stratégiai tervezés, mint a közösségi tervezés egyik formája, olyan eszköz, mely a segítheti a közösség részvételét a döntéshozatalban, és segítheti konszenzus kialakítását társadalmi vitán keresztül. Azonban van a közösséginek nevezett tervezésnek egy sötét oldala is. A kritikusok állítása szerint eszköze lehet a vélemény manipulálásának, az érintettek egyes csoportjának kizárásának és végső soron a döntéshozói akarat közösségre való kényszerítésének is. (Harris 2002: 31-32). Azok az alkalmak, amikor a közösségi 
tervezés fogalmát a közösség véleményének manipulálására használják, nem csak a tervezők, hanem a tervezési módszer hitelességét is aláássák. (Bartha 2008: 57.) Mindezek a veszélyek ellenére egyetértés látszik mutatkozni abban, hogy a közösségi tervezés eszközei jelentős mértékben hozzájárulhatnak az irányítás eszközeinek a kormányzás eszközeivel való felváltásához ${ }^{14}$ és ezzel „demokrácia elmélyítéséhez” (Fung \& Wright 2001: 5.)

Észre kell vennünk, hogy a témakört vizsgáló tanulmányok a stratégiai tervezést egy adott szervezet tevékenységére fókuszálva értelmezik. Ez jelzi a stratégia tervezés nem érték-független, poszt pozitivista jellegét. Azzal, hogy kijelentjük a stratégiai tervezés poszt-pozitivista tervezési módszer, egyúttal azt is kijelentjük, hogy túllép a pozitivista tervezésnek azon megközelítésén, mely szerint fejlesztési célok meghatározását tervezőre kell bízni, mivel a tervező szaktudása révén tisztában van a döntési helyzettel, és így jobb döntéseket tud hozni, mint a megbízója, vagy a laikus lakosság. (Chadwick 1971:21) A poszt-pozitivista megközelítés a tervezőt ezzel szemben egy esendő tanácsadónak látja egy komplex világban, ahol nincsenek egyértelmű válaszok, csak diverz és bizonytalan lehetőségek. A poszt-pozitivista szemléletben a tervezési folyamatok meghatározó tényezői a fragmentáció, a többszörösség, a szubjektivitás, és az interpretáció. (Allmendinger 2002a: 88) Talán nem meglepő, ha a korábban szakértői szerephez hozzászokott tervezői társadalom, valamint az egyszerü és gyorsan megadható válaszokra éhes kuncsaftjaik egyaránt fenntartásokkal fogadják az új eszközt és lehetőség szerint továbbra is pozitivista tervezés módszereket használnak a településfejlesztési tervezésben.

A Integrált Településfejlesztési Stratégia tartalmi követelményeit meghatározó magyar jogszabály a fentiekkel összhangban van. 314/2012. (XI.8.) kormány rendelet 2. mellékletében felsorolt tartalmi követelmények között az önkormányzat a célok elérését szolgáló nem beruházás jellegü tevékenysége, a megvalósítás szervezeti kereteinek meghatározása, valamint a megvalósulás monitoringja egyaránt szerepel. A jogszabály ugyancsak hosszan, 28-48. paragrafusok között részletezi a településfejlesztési dokumentumok „partnerségi egyeztetésének” szabályait. A dokumentumból kivezető, a jogalkotó szándéka a poszt-pozitivsta tervezési módszertan elterjesztésében. Amint azonban a későbbi kutatási fejezetekben látni fogjuk, a jogszabályalkotás nem a leghatékonyabb eszköze a sem a szervezetfejlesztésnek, sem az új tervezési módszerek meghonosításának.

${ }^{14}$ az irányítás-kormányzás kifejezéseket a government-governance kifejezések fordításaként használom. 


\subsection{Nemzetközi esettanulmányok}

Nemzetközi esettanulmányok között két olyan városmegújítási beavatkozást vizsgál a dolgozat, melyek keretében a szabadterek megújításának döntő szerepük volt. Az első esettanulmány a Barcelonában az 1970-es években elindult, az 1992-es olimpián leginkább intenzívvé váló, de azt követően is folytatódó rehabilitáció folyamata. Itt másodlagos irodalmi forrásokat (szakmai publikációkat) vizsgálva tekinti a dolgozat át, hogy milyen településmegújítási stratégia mentén valósult meg a beruházás. A második esettanulmány London 2012. évi olimpiai helyszínének a megújítási projektje. Ennek kapcsán elsődleges irodalmi források (tervdokumentumok, internetes és hagyományos publikációk, a projekthez kapcsolódó honlapok) alapján veszi a tanulmány sorra, hogy milyen települési problémákra ad a megvalósuló projekt választ, milyen szervezeti struktúrában valósul meg a beruházás, és milyen eredményeket várnak a szereplők.

\subsubsection{A „Barcelona modell”}

Az 1990-es évek óta a „Barcelona modell” fogalma, mint a közterületi dizájnra alapozott önkormányzati városmegújítás mintája került be a szakmai köztudatba. (Newman és Thornley 2005: 180) Mások a Barcelona modellt, mint a globalizáció kihívásaira és lehetőségeire adott adaptációs válaszként tekintik. (Marshall 2000: 299) A megújítás az 1992-es olimpiai játékok kapcsán vált széles körben ismertté, azonban Barcelona közterületi alapú megújítása lényegesen korábbra datálódik, mint az olimpia rendezési jogának elnyeréséről szóló döntés. Monclús hangsúlyozza, hogy a településtervezésnek Barcelona esetében különleges szerepet biztosít az, ahogy az 1970-es évek friss demokráciájában a tervezési folyamat a demokrácia egyik megtestesítőjévé vált. (Monclús 2003: 401) A várospolitika alakulása nyomon követhető a 1980-as évektől a 1990-es évek végéig tartó stratégiai tervek során keresztuil. Az olimpia megrendezésére irányuló törekvés a város átfogó fejlesztési stratégiájának részét képezte, mely a környezetminőség és település arculat javítását és kulturális fejlesztések megvalósítását tủzte zászlajára. Barcelona esetében a közterületek megújítása nem az olimpiai projekt kapcsán kezdődött meg, hanem már az 1980-as években. A 1970-es éveket követően Európa szerte kezdték a funkcionalista várostervezés bírálataként a közterületeket többnek tekinteni, mint az épületek közti üres térnek. (Gehl 2001: 6) Ezen túlmenően a 1970-es évek recessziója is szerepet játszott abban, hogy viszonylag alacsony költségvetésü és könnyen menedzselhető közterületi rehabilitációs projekteket valósított meg a barcelonai önkormányzat. „Lépjünk túl a szabályozás korlátain, hogy teret kaphasson az építészet” volt a korszak jelmondata. (Monclús 2003: 405.) 
Az 1979-es első demokratikus önkormányzati választásokat követően kezdődtek el a kisebb közterületek ütemezett felújításai Barcelonában, melyek között voltak új közterek (placa Sóller, placa del Paisos Catalans) és megújított közterek is (placa Reial, placa de la Mercé). Ezek a kisléptékü felújítások kezdetben nagy intenzitással folytak, azonban az olimpiai pályázat sikere után a nagy volumenü beruházások elszívták ezektől a fejlesztési forrásokat. Az 1982-92 közötti időszakban több mint 200 ha parkterület létesült legtöbbször egykori ipari területek helyén. A közterület felújítás eredményeképpen számos szomszédsági egység megújult, de ami ennél is fontosabb, magas presztízsủ közterületek születtek, hála a színvonalas közterület építészetnek. Permanyer a felújítások jelentőségét abban látja, hogy „,ezzel a [település]politikával nem pusztán a városi táj gazdagodott, de általa számos olyan kulcsfontosságú helyszín is identitást nyert, melyek ez idáig nem rendelkeztek karakterrel és [érzékelhetö] helytörténetiséggel”. (Benach 2004: 154). Oriol Bohigas, a polgármester városfejlesztési tanácsadója, aki az építészeti koncepció kidolgozását nagyrészt koordinálta, a megújítás koncepcióját a következő módon foglalta össze:

„Célkitüzéseink világosak. A közterületek megújítását kezdjük két ok miatt: egyrészt hogy a minőség közterületeit megteremtsük, másrészt, hogy a fejlesztés fókuszait kialakítsuk, melyek a későbbiekben segíthetik a területek spontán transzformációját. Egészen egyértelmü, hogy amikor egy lepusztult lakókörzetben felújítunk egy közterületet, az egy nagyon koncentrált, jól érzékelhetö beavatkozás mely, mint a környezet regenerációjának motorjaként szolgál majd” (Benach 2004: 155)

Barcelonában a stratégiai tervezés ugyancsak jelentős hatással volt a településfejlesztésre. A 1990ben és 1994-ben készült stratégiai tervekben, ahol a készítést közgazdászok vezették, a célkitűzés a Barcelonai agglomeráció Európa vezető, és versenyképes térségévé való alakítása volt. A fejlesztések fókuszában az információs technológia, egészség, egyetemek és a turizmus „minőségi hálózatainak" létrehozása állt. A stratégiai tervezés folyamatában jelentős számban vettek részt az érintettek (2-3 ezer fő), mindazonáltal a tervezés alapvetően a vezető elitek (városházi képviselők és szakértők) dominanciájával valósult meg. Az 1998-ban készített harmadik stratégiai terv úgy definiálja Barcelonát, mint „,metropolisz térség, mely a világ vérkeringésére kötött, mely innovatív és tudás alapú, melynek intézményi kapacitásai lehetőségeket biztosítanak lakosainak a gazdasági fejlődésre” (Associacio’ Pla Estrategic Barcelona quoted in Marshall 2000: 308). A stratégiai tervezés a városi léptéknél nagyobb összefüggésekre koncentrál. Barcelona egykori polgármesterhelyettese Jordi Borja, könyvében azt állítja - minden bizonnyal a barcelonai gyakorlatára alapozva -, hogy a stratégiai tervezés átveheti a hagyományos területhasználati vezértervek szerepét, és a részvételi módszertanával egy dialektikus tervezési módszert valósíthat meg a nagyléptékü fejlesztési beruházásokkal összefonódva. (Borja és Castells 1997: 172 quoted in Marshall 2000: 
315) A stratégia tervezés sikerességét illetően azonban vannak kételyek. Barcelona 1981 és 1996 között 250000 lakost vesztve 1,5 millió lakossal bírt. Ezzel párhuzamosan exponenciális növekedés volt megfigyelhető a gépjármühasználatban. ,1988-ban még 600000 volt a közigazgatási határt naponta átlépő személygépkocsik száma, ami 1998-ra a duplájára növekedett. (Monclús 2003: 414.) Kérdéses tehát, hogy a központi területek megújítását célzó fejlesztések eredményesen mérsékeltéke a szuburbanizációs folyamatokat.

Részben a stratégiai tervezés folyamata teremtette meg azt a sajátosságot, hogy a tervezési folyamatok nyitottá váltak a lakosság számára. Ebben elsősorban a jelentős befolyással bíró Barcelona Szomszédsági Egyesületek Szövetsége (Federació d'Associacions de Veïns de Barcelona FAVB) volt jelentős súllyal képviseltetve. Az 1990-es évek a városi önkormányzat által kezdeményezett nagyszámú közösségi tervezési programot Marshall véleménye szerint lehet, hogy pusztán politikai populizmus, de az is lehet, hogy valódi nyitási szándék motiválta. Minden esetre a kormányzás [governance] alapú önkormányzati modellre való áttérés Barcelona esetében csak részleges, befejezetlen és bizonytalan alapokon nyugvó (Marsahall 2000: 314). Benach kritikájában azt fogalmazza meg, hogy az olimpiai projekt során az emberek, akikre oly sokszor hivatkoztak a politikusok, inkább statisztái és nem aktív szereplői voltak a folyamatoknak. (Benach 2004: 150).

A Barcelona modell másik jellegzetességeként tartják számon azt, ahogy a PPP beruházások meghatározó elemeivé váltak a fejlesztéseknek. (Newman és Thornley 2005: 182) A gazdaságélénkítő fejlesztések során általános recept volt a látványos zászlóshajó beruházások megvalósítása, mely a város, esetleg a régió egészének az imidzsét átalakítja, és amely következtében a magán beruházók is bátorságot nyernek a befektetésre. A barcelonai olimpia ezen zászlóshajó fejlesztéseknek egyik iskolapéldájaként értékelhető. (Hall 1996: 343) A beruházás fókusza a város tengerparti területén lévő ipari helyszínek valamint a kikötő területének a revitalizációja volt. Ezzel párhuzamosan azonban további jelentős beruházások valósultak meg az „Új Középpontok” (Nova Centralitat) helyszínein. Ezek a projekthelyszínek nem új települési alközpontokként voltak értelmezhetők, hanem új központi funkciókkal bíró helyszínekként. Kettő ezek közül olimpiai színhelyként is szerepel, kettő jelentős közúti csomóponthoz kötődött, kettő további pedig a vasúti hálózat csomópontjai mellett helyezkedett el. A területek közös jellemzője volt, hogy nagy volumenű új funkció befogadására voltak alkalmasak, részben a meglévő szabad területek beépítése, részben a már beépített, de degradálódott területek átépítése révén. (Esteban 2004: 126) Monclús megítélése szerint a Barcelona revitalizációs programjai a város belső területeinek sikeres megújulását eredményezték, a magas színvonalú dizájn és a funkciók bővítése hozzájárult a város vitalitásának növeléséhez. Azonban hibájaként rója fel, hogy az urbanizált 
területek perifériáinak szétterülését nem volt képes kellő kontrol alá helyezni. A projekt kapcsán megvalósult nagy volumenű kereskedelmi beruházások (Maremagnum, La Maquinista) igen sikeres kombinációi a köz- és magánszférának, melyek üzleti szempontból nagy sikert értek el. Ezen bevásárlóközpontok sikere azonban a város közterületeinek funkcióival konkurál. A Diagonal Mar ${ }^{15}$ komplex bevásárló és szabadidő központ valamint luxus ingatlan projektje számos kritikát váltott ki, alacsony beépítési intenzitása, szociális izoláltsága, az általa okozott közlekedési problémák, valamint a helyi lakosság igényei helyett a turisták igényeit kiszolgáló szolgáltatások miatt. ${ }^{16}$ Marshall kritikája szerint a barcelonai fejlesztések során a magán beruházók forrásaitól való erős fügés okozott problémát, ahol a beruházások forráshiány miatt többször leálltak. Ez éles ellentétben áll az 1980-as évek költségvetési finanszírozású fejlesztéseivel. (Marshall 2000: 313) Monclús megítélése szerint ezzel némiképpen ellentmondásban, Barcelona esetében sikerült elkerülni a szegregációt mely számos piac vezette fejlesztés esetében problémát okoz. (Monclús 2003: 417) A program eredményének tekinthető, hogy az egykori ipari területek egyes részein közparkok és rekreációs intézmények létesültek, míg az olimpiai falu területén piaci beruházók által megvalósuló ingatlanfejlesztéseket, amelyek a későbbekben magas ingatlanárakat eredményeztek, és a szegregációt erősítő elemként írhatjuk le. (Marshall 2000: 304)

Pasqual Maragall, Barcelona egykori polgármestere a városi megújulásról szóló kiadvány előszavában hangsúlyozza: „fontos megértenünk, hogy a közterületek minőségének javítása fontos szerepet játszik a társadalmi és gazdasági nehézségek megoldásában” Állítása szerint, Barcelona „trükkje” a minőségnek a mennyiség elé helyezése, illetve a város megújulásának a sikerének a záloga a városháza és az Építészeti Egyetem együttmüködése volt. (Rodgers 1999: 5) Mások, kritikus éllel, a befolyásos elit városának hívják Barcelonát, ahol a fejlesztések során nem fordítottak kellő figyelmet a szociális szempontokra. Az olimpia időszakának eufóriájában nem jelent meg, vagy legalábbis nem hallhatóan a fejlesztést kritizálók hangja. Az azóta eltelt időszakban azonban már objektívebbé vált a program megítélése, elismertté váltak a dzsentrifikáival okozott hibák. (Newman és Thornley 2005: 183) A modellt azonban több európai város is mintának tekintette, és megpróbálta, több-kevesebb sikerrel adaptálni.

\footnotetext{
${ }^{15} \mathrm{http} / / / \mathrm{www}$. diagonalmar.com/ accessed on 2011-02-10

${ }^{16} \mathrm{http} / / /$ www.pps.org/great_public_spaces//one?public_place_id=623 accessed on 2011-02-10
} 


\subsubsection{London Olimpia 2012, a Lea folyó völgyének revitalizációjával}

A londoni olimpiai játékok központi helyszíneként ${ }^{17}$ a Lee-folyó völgyének torkolati szakaszán, London belső, keleti városrészei mellett elterülő, mintegy $2,5 \mathrm{~km}^{2}$ kiterjedésű területe szolgál. (ODA 2006) A Big Bentől légvonalban mindössze mintegy 10 km-es, a Temzétől 4,5 km-es távolságra lévő, több mint száz éven át ipari valamint hulladéklerakó zárvány terület volt. A terület meg volt, illetve részben még ma is meg van ,áldva” a rozsdamezős térségek összes jellemző ismérvével; szennyezett talaj, rossz állapotú épületállomány, hiányos, illetve rehabilitációt gátló közműellátottság, közlekedési kapcsolatok hiánya a szomszédos városrészek felé. ${ }^{18}$

A Lea-folyó alsó völgyének rehabilitációja olyan revitalizációs projekt, mely a térség, illetve London egésze számára, az olimpia megrendezésétől függetlenül, régóta deklarált célkitűzése. Az olimpia „elkötelezettség a fenntartható megújítás mellett” címü Olympic Delivery Authority (Olimpia Megvalósítási Hatóság ODA) kiadványa szerint: „... A játékok sikeressége az Alsó-LeaVölgy [Lower Lea Valley] mentén a megújulás átütő ereje alapján is meghatározásra kerül. A London 2012 Játékok egy soha vissza nem térö lehetőséget jelentenek az Alsó Lea Völgy regenerációjában, új otthonok, munkahelyek, iskolák, egészségügyi és közösségi - és természetesen világszínvonalú sportolási intézmények megteremtésében. Célunk, hogy az Olimpiai Park a Leavölgy színvonalas, jól tervezett és átfogó regenerációjának kiindulópontjává váljon.” (ODA - LDA 2007: 3) A 246 ha összterületủ beruházás a legnagyobb építési projekt Európa történetében, állítja az ODA tervezési programját ismertető kiadvány. A fejlesztés révén, mely 21. századi minőségi városi területek kialakítását tervezi, katalizálni fogja a térség társadalmi, környezteti és fizikai megújulását.

A beruházás várható eredményeket az ODA által kiadott „Befektetés a jövőbe” népszerüsítő kiadvány mutatta. A kiadvány fö üzenete, hogy a beruházás nem „csupán” egy sport és kulturális célú világrendezvényről szól, hanem London hátrányos helyzetü, keleti területrészének a regenerációjáról, a térség megújulásának elindításáról.

- Minden befektetett fontból 75 penny hosszú távú regenerációs célokra fordítódik.

- A beruházásban résztvevők között legalább 9\% lesz a korábban munkanélküliek aránya.

- Az egykori ipari területen lévő 1,8 millió köbméter erősen szennyezett talajt ártalmatlanítják, helyén nagykiterjedésü zöldfelületek létesülnek. Talajmosó berendezések segítségével 70000 köbméter ipari és háztartási hulladékkal szennyezett talajt tisztítanak meg és hasznosítanak újra.

- $\quad$ A területen lévő 52 nagyfeszültségü vezetéket kiváltják és 6 km-es kábel-alagutat alakítanak ki.

\footnotetext{
${ }^{17} \mathrm{http}: / / \mathrm{maps}$. google.com/maps/ms?ie=UTF8\&hl=hu\&msa=0\&ll=51.540036,$0.007553 \& \mathrm{spn}=0.07367,0.153809 \& \mathrm{t}=\mathrm{h} \& \mathrm{z}=13 \& \mathrm{msid}=108329671842255437187.000462515 \mathrm{e} 5 \mathrm{faee} 0 \mathrm{~d} 80 \mathrm{e} 2$

${ }^{18} \mathrm{http}$ //www.london2012.com/press/media-releases/2007/10/low-level-radium-contamination-from-10cm-gauge-dialfound-on-site.php
} 
- A területen az elavult kábel és vezetékhálózat felszámolásával párhuzamoson a hosszú távú fejlesztéseket megalapozó high-tech vezetékhálózatot létesítenek.

- $\quad$ A területen 1,8 km hosszúságú szennyvízcsatorna hálózat épül.

- A terület energiaigényének 20\%-át megújuló energiaforrásból biztosítják.

- A játékok után több, mint 100 hektáros új közhasználatú rekreációs szabadteret adnak át a környék lakosainak.

- $\quad$ A park területéből 45 hektáron rehabilitálják a természetes élőhelyeket.

- $\quad 8$ km hosszúságban revitalizálják a Lee-folyó medrét, új zöldfolyosót alakítva ki a város területén.

- $\quad$ London tömegközlekedéssel rosszul ellátott területén jelentős közlekedési fejlesztések történnek a metró vonalakon és a Docklands magas vasúton, és Stratford állomáson, amely regionális vasúti csomóponttá alakul.

- Több mint 30, többségében gyalogos híd létesül a területen, amelyek a játékokat követően a térség ez idáig egymástól elválasztott területrészeit kapcsolják majd össze.

- A világszínvonalú sportlétesítmények a játékokat követően a profi sportolókon kívül a helyi közösség rekreációs igényeit is szolgálják, egyúttal inspirációt biztosítanak a jövő bajnokai számára.

- Az olimpiai falu területén 3000 magas színvonalú lakás épül, vegyesen a különbözö jövedelmü lakossági rétegek számára.

- A terület fejlesztési szerves részét képzi Stratford városrész, és a Temze Kaputérség regenerációs programjának. (ODA 2008: 2-5)

A 2012 Londoni Olimpia Játékok beruházásának és program lebonyolításának szervezeti keretében $^{19}$ két kulcsfontosságú szereplője volt. Az egyik az Olimpiai Játékok Londoni Szervezőbizottsága (London Organising Committee of the Olympic Games LOCOG), mely a játékok szerezéséért felelős üzleti finanszírozású szervezet. 2 mrd GBP nagyságú költségvetését az üzleti szektor segítségével tervezi megteremteni. Forrásait a Nemzetközi Olimpiai Bizottságtól kapott támogatások mellett a jegyeladásból, termékértékesítésből és döntő részben szponzori bevételekből szerzi. ${ }^{20}$ Az Olimpia Megvalósítási Hatóság (Olympic Delivery Authority ODA) a kormány 2006-os olimpiai törvénye által létrehozott szervezett. Ez az állami szervezet volt felelős a létesítmények határidőre történő elkészítéséért. A finanszírozását a Kulturális Média és Sport minisztérium, Nagy London Önkormányzata, London Fejlesztési Ügynökség és az Olimpiai Lottóalap végzte. Ez a finanszírozás biztosította az anyagi hátteret a fejlesztési beruházásokhoz. Az ODA az Olimpiai Park megvalósításán felül felelt az egyéb helyszíneken (Weymouth , Portland, Broxbourne, Eton Dorney) zajló építésekért is. Az ODA illetékességi területén átvette az érintett önkormányzatoktól az építés hatósági jogkört. A hatóság a hozzá beérkező építési engedélykérelmeket online adatbázisában tartotta nyilván és tette elérthetővé a nyilvánosság számára. ${ }^{21}$ Az olimpiai játékok lezárultát követően a 2012 áprilisában megalakított London Örökség Fejlesztési Társaság (London Legacy Development Coorparation LLDC) folytatja a terület rehabilitációjának koordinálását. ${ }^{22}$

\footnotetext{
${ }^{19} \mathrm{http}: / / \mathrm{www}$. london2012.com/funding-the-games

${ }^{20} \mathrm{http} / / / \mathrm{www}$. london2012.com/about-us/the-people-delivering-the-games/the-london-organising-committee/

${ }^{21} \mathrm{http}: / / \mathrm{www}$. london2012.com/planning/planning-register.php

$22 \mathrm{http} / / / \mathrm{www}$. londonlegacy.co.uk/about-us/what-we-aim-to-achieve/
} 
A projekt megvalósításában számos egyéb szervezett is aktív részt vállalt: A Nemzeti Lottó (National Lottery) az eredeti tervek szerint 2,2 mrd GBP összeggel támogatta az olimpiai fejlesztéseket. ${ }^{23}$ A Kulturális, Média és Sport Minisztérium (Department for Culture, Media and Sport DCMS) a kormányzatot képviselte a projekt megvalósítása során. (DCMS 2011: 3) Nagy London Önkormányzata (Greater London Authority GLA) a város polgármesterének olimpiára vonatkozó célkitüzéseinek megvalósításában müködött közre. ${ }^{24}$ A London Fejlesztési Ügynökség (London Development Agency LDA) egyike a kormány által felállított kilenc regionális fejlesztési ügynökségnek. GLA tanácsadójaként segítette London polgármesterét a térség fenntartható fejlesztését szolgáló programok megalkotásában. Az olimpia kapcsán a szervezet felelőssége volt, hogy „biztosítsa azt, hogy London tartós társadalmi, fizikai, gazdasági és kulturális eredményeket kap örökül a 2012-es játékokat követöen”. ${ }^{25}$.

Az olimpia beruházás költsége természetesen élénken foglalkoztatta a közvéleményt. A megvalósítás becsült költsége jelentős mértékben emelkedett a rendezés jogának megszerzését követően.

2. táblázat: Londoni Olimpia 2012 költségvetésének változása (forrás: House of Commons 2007, DCMS 2011)

\begin{tabular}{|l|c|c|c|}
\hline \multicolumn{1}{|c|}{ Költségek } & $\begin{array}{c}\text { Olimpiai pályázat } \\
\mathbf{( 2 0 0 4 )} \\
\text { m GBP }\end{array}$ & $\begin{array}{c}\text { 2007-es } \\
\text { költségvetés } \\
\text { m GBP }\end{array}$ & $\begin{array}{c}\text { 2011-es } \\
\text { költségvetés } \\
\text { m GBP }\end{array}$ \\
\hline ODA költségvetés & 3650 & 4754 & 6127 \\
\hline $\begin{array}{l}\text { Egyéb projekt- } \\
\text { költségek (nem ODA) }\end{array}$ & 386 & 388 & 1226 \\
\hline Egyéb szolgáltatások & - & 3683 & - \\
\hline Tartalék & - & 2747 & 1972 \\
\hline \multicolumn{1}{|c|}{ Összesen } & $\mathbf{4 0 3 6}$ & $\mathbf{9 3 2 5}$ & $\mathbf{9 3 2 5}$ \\
\hline
\end{tabular}

2008-ban a hiányzó állami források biztosítása céljából a parlament költségvetési bizottsága a projekt költségvetésének 5,9 millió fontos növeléséről rendelkezett. Ebböl a költségvetés 4,9 millió, a GLA 300 millió, a Nemzeti Lottó 675 millió fontot állt. (House of Commons 2008: 8) A DCMS mind 2009, mind 2011 években kiadott éves jelentéseiben a beruházás végösszege a 2007-es parlamenti határozathoz igazodott. Azonban ezek a költségek nem tartalmaztak számos egyéb járulékos költséget, mint a terület kisajátítását (766 mGBP), az olimpia utáni területrendezési költségeket (826 mGBP) és az OPLC müködtetésének költségét (300 mGBP). Ezekkel a tételekkel együtt a beruházás költsége a 12 milliárd GBP nagyságrendhez közelít, amely költségek még nem

\footnotetext{
${ }^{23}$ http://www.olympiclotterydistributor.org.uk/docs/home.php

${ }^{24} \mathrm{http}: / / \mathrm{www}$. london.gov.uk/

${ }^{25} \mathrm{http}: / / w w w . l d a . g o v . u k /$
} 
tartalmazták a közbiztonság, terrorelhárítás és a kapcsolódó tömegközlekedési fejlesztések tetemes költségeit. (Hervey \& Chennaoui 2012)

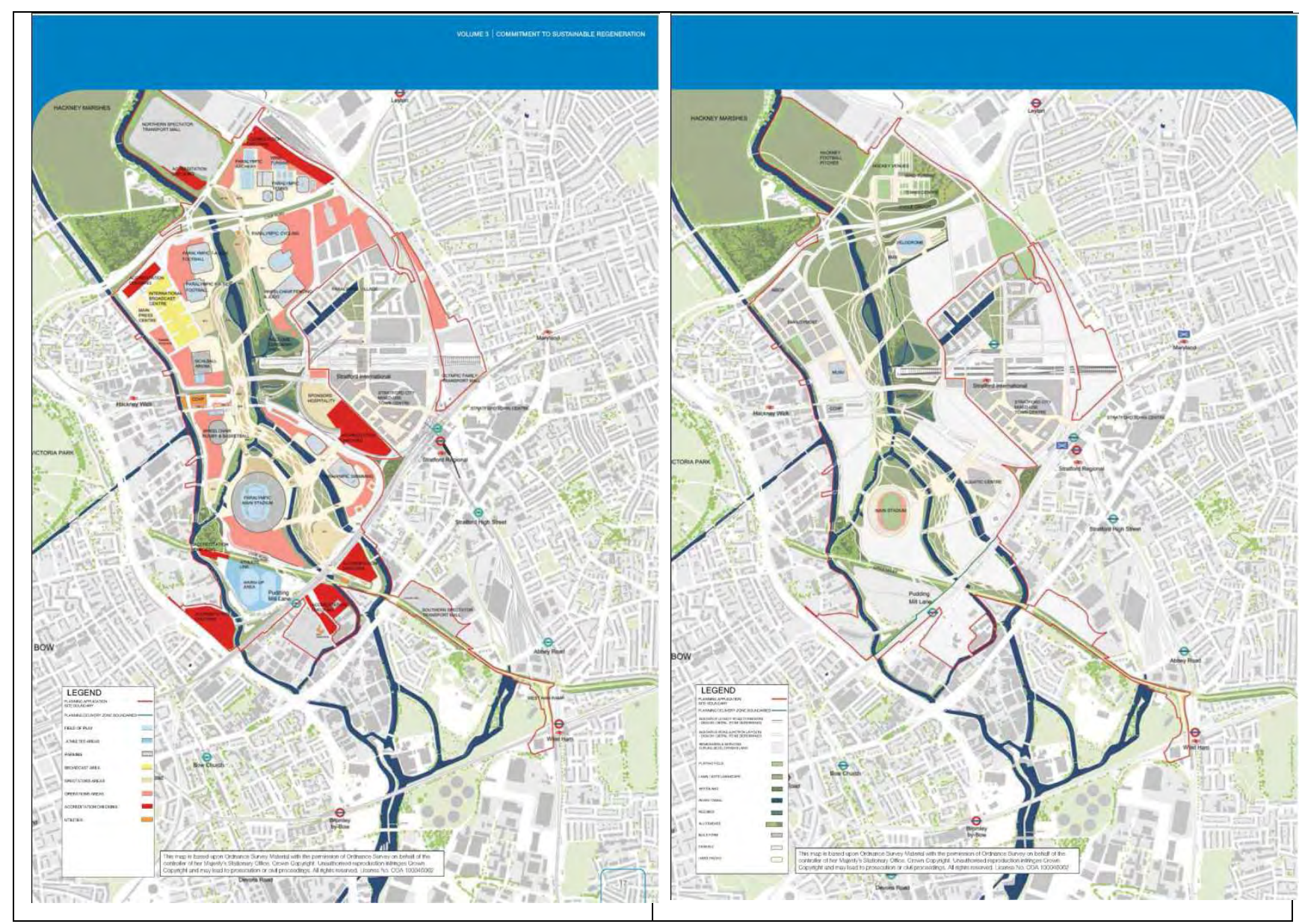

3. ábra: London 2012 Olimpia helyszíne az a játékok idején és a „túlhasznosítást” követően. (forrás ODA-LDA 2007: 17-18).

A londoni olimpia beruházás több szempontból is szabadtér rehabilitáció fókuszú projektnek tekinthető. Míg az olimpia megrendezése idején a területen az épületek domináltak, az Erzsébet Királynő Olimpiai Park néven történő 2013. júliusában való megnyitását követően a terület rekreációs, szabadterek által dominált rendezvénytérré vált.. ${ }^{26}$

3. táblázat: London 2012. olimpiát követően az Erzsébet Királynő Olimpiai Park területén tervezett fejlesztések ${ }^{27}$

\begin{tabular}{|l|r|}
\hline \multicolumn{1}{|c|}{ Beruházási elem } & \multicolumn{1}{c|}{ Becsült mennyiség } \\
\hline Új lakások & $8000 \mathrm{db} 480000 \mathrm{~m}^{2}$ \\
\hline Új kereskedelmi terület & $910000 \mathrm{~m}^{2}$ \\
\hline Új zöldfelület [greenspace] & 357 focipálya, $560 \mathrm{acre}$ \\
& $2265760 \mathrm{~m}^{2}$ \\
\hline
\end{tabular}

\footnotetext{
${ }^{26} \mathrm{http}: / / \mathrm{www}$. londonlegacy.co.uk/

${ }^{27} \mathrm{http}: / /$ noordinarypark.co.uk/
} 


\begin{tabular}{|l|r|}
\hline Felszíni vízfolyás & $6,5 \mathrm{~km}$ \\
\hline Gyalogos és kerékpáros út & $35 \mathrm{~km}$ \\
\hline
\end{tabular}

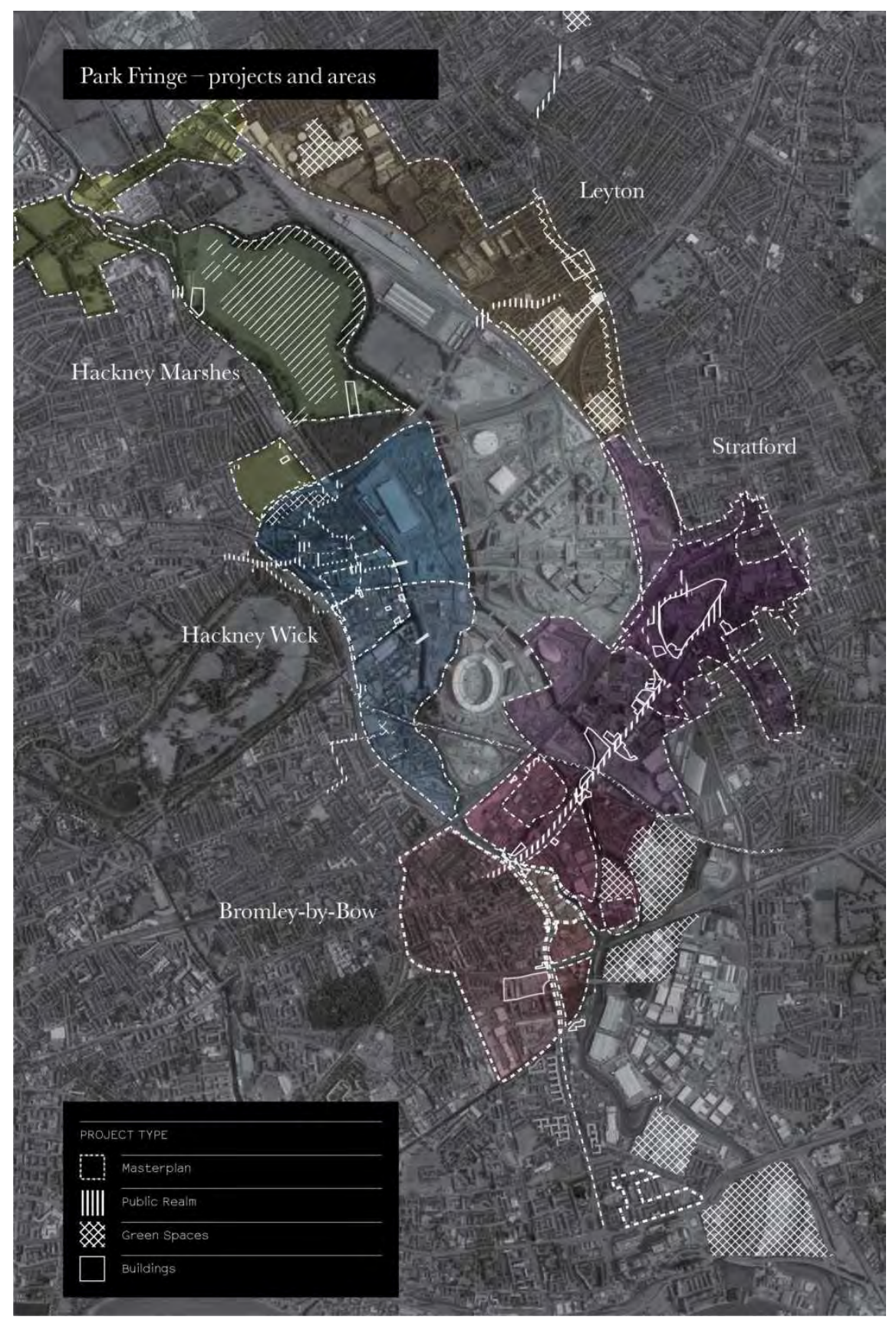

4. ábra: London 2012. olimpiát követően az Erzsébet Királynő Olimpiai Park szomszédságában tervezett fejlesztések (forrás LLDA 2007: 33).

Ezen felül, London polgármestere, Boris Johnson által elnökölt LLDC feladatának tekinti, hogy az olimpiát követően a park szomszédságában lévő területeken a felújítások folytatódjanak annak érdekében, hogy az olimpiai játékok kapcsán véghezvitt átalakulás teljessé váljon és ezzel KeletLondon egy sikeres új kerülete szülessen meg. (LLDC 2012:3). Ennek szellemében az LLDC fejlesztési programot határozott meg az olimpia utáni időszakra, az olimpia parkkal szomszédos területek fejlesztésére. A Peremterületek Összefüzése (Stiching the Fringe) nevet viselő program 
keretében mintegy 100 projektet hirdettek meg az Olimpia Parkkal szomszédos területeken, melyeket a fejlesztési társaság finanszíroz, koordinál, vagy véleményez. A dokumentum tanulsága alapján, ezek a projektek között dominálnak a közterület fejlesztési és zöldterület fejlesztési beruház ások, bár az egyes területrészek közötti arányok jelentős mértékben eltérnek.

4. táblázat: A Stiching the Fringe program keretében tervezett fejlesztések

\begin{tabular}{|l|c|c|c|c|c|}
\hline \multirow{2}{*}{ Helyszín } & \multicolumn{5}{c|}{ Beavatkozás típusa } \\
\cline { 2 - 6 } & $\begin{array}{c}\text { Vezérterv } \\
\text { készítés }\end{array}$ & $\begin{array}{c}\text { Közterület } \\
\text { fejlesztés }\end{array}$ & $\begin{array}{c}\text { Zöldterület } \\
\text { fejlesztés }\end{array}$ & $\begin{array}{c}\text { Épület } \\
\text { létesítés }\end{array}$ \\
\hline Leyton & 2 & 4 & 4 & 1 & $\mathbf{1 1}$ \\
\hline Stratford & 5 & 6 & 2 & 3 & $\mathbf{2 2}$ \\
\hline Hackney Marshes & 4 & 3 & 5 & 5 & $\mathbf{2 5}$ \\
\hline $\begin{array}{l}\text { Hackney Wick } \\
\text { Fish Island }\end{array}$ & 3 & 13 & 4 & 5 & $\mathbf{2 4}$ \\
\hline Bromley-by-Bow & 11 & 6 & 2 & $\mathbf{2 4}$ & \\
\hline Összesen & $\mathbf{2 5}$ & $\mathbf{3 2}$ & $\mathbf{1 7}$ & 5 \\
\hline
\end{tabular}

Az esettanulmányokról összefoglalóan az állapítható meg, hogy Barcelona esetében a településmegújításra tett erőfeszítések széleskörü társadalmi támogatottságra támaszkodhattak, mely jelentős részben a Franco uralmat követő demokratikus korszak közös eredményének tekintette a tervezés, majd később a megvalósítás folyamatát. Ez a tervezési folyamat Barcelonát és agglomerációját érintő stratégiatervezés, illetve a városon belüli kisléptékü szabadtér rehabilitációkkal indult, majd az 1992-es olimpiai játékok kapcsán megvalósult felújításban csúcsosodott ki. Barcelona esetében a stratégia szintű tervezés és a kisléptékü szabadtérépítészeti projektek egyaránt karakteres és fontos elemei voltak a városfejlesztési tevékenységeknek. A településfejlesztési programok kidolgozásában fontos szempontként jelent meg az érintettek bevonása. Azzal kapcsolatban azonban megoszlanak a vélemények, hogy ezek a participációs folyamatok valóban kétirányú kommunikációt jelentettek a lakosok és a városvezetés között, vagy csak látszólagos volt az érintettek bevonása a döntéshozatalba. Barcelona esetében a PPP beruházások ugyancsak jellegzetes elemei voltak a város átalakulásának. Ezek a fejlesztések nagy volumenü és jelentős építészeti átalakulásokat produkáltak degradálódott, alulhasznosított területeken. Kritika azzal kapcsolatban éri a „Barcelona modell” ezen elemét, hogy a fejlesztések a területen élők igényeit és szempontjait sokszor figyelmen kívül hagyták.

London 2012-ben megrendezett olimpiai helyszíne a Lea-folyó völgyében lévő mintegy 2,5 km²-es területe a város keleti, külvárosi városrészében lévő egykori rozsdamezős terület. A korábban ipari és hulladéklerakó hasznosítású rozsdaövezeti terület, mely a város szegényebb, keleti részén található zárványként ékelődve a környező kerületek közé. Az olimpia megvalósításához a kormányzat egy önálló olimpiai hatóságot (Olympic Delivery Authority) alakított, mely az építéshatósági feladatok mellett a beruházás lebonyolítását is végezte. Az olimpiával kapcsolatos 
kommunikáció fontos eleme volt az olimpia hagyatéka (Olympic Legacy), mely alatt azokat a társadalmi, gazdasági, környezeti hasznokat értik, melyek az olimpiai beruházás révén a megvalósítás során, illetve azt követően realizálóadnak. A Lea-folyó völgyének regenerációja a tágabb térség zöldhálózat fejlesztési programjaihoz szervesen kapcsolódik a Thames Gateway Parklands térségi együttmüködési programon keresztuil. A kormányzat az Olimpiai Park területének utóhasznosítása kapcsán egy projekt társaságot (Olympic Park Legacy Company) hozott létre. Ennek lesz feladata a terület olimpia utáni átalakulásának irányítása, a területen „21. századi kertváros kialakítása, mely integrációt, megújulást és jólétet eredményez a kelet-londoni térségben."

Figyelemre méltó elképzelés, hogy az olimpia ideje alatt „túlhasznosított” állapothoz képest a terület beépítettségének csökkentésére, az ideiglenes épületek lebontására kerül sor. Ezt követően a folyó menti megújított közterületek mentén felszabaduló építési helyszínek piaci alapú, fokozatos beépítése előtt nyílik meg a lehetőség. A kritikusok is elismerik, hogy a terület korábbi állapotánál az olimpiát követően egy lényegesen kedvezőbb állapot alakult ki. Kritika azzal kapcsolatban fogalmazódik meg, hogy a beruházás előkészítése során nem vizsgáltak egyéb revitalizációs alternatívákat az olimpia rendezés rendkívül költséges opciójával párhuzamosan. Így nem derülhetett ki, hogy a terület megújításának lett-e volna egyéb, az adófizetők pénztárcáját jobban kímélő alternatívája.

Tanulságos eredménnyel szolgál, ha Adams-ék az 1.3. fejezetben bemutatott településmegújítási tipológiája szerint csoportosítjuk a két mintaprojekt során használt városmegújítási eszközöket.

5. táblázat: A külföldi esettanulmányokban használt rehabilitációs eszközök típusai (Adams et al. 2003: 64/ 4.1 táblázat alapján)

\begin{tabular}{|c|l|l|}
\hline $\begin{array}{c}\text { Településmegújítási } \\
\text { eszközök típusai }\end{array}$ & \multicolumn{1}{|c|}{ Barcelona } & \multicolumn{1}{c|}{ London Olimpia 2012. } \\
\hline \multirow{4}{*}{ Piac alakítás } & $\begin{array}{l}\text { Stratégia tervezés 1990 teljes } \\
\text { agglomerációra európai } \\
\text { versenyképes térség }\end{array}$ & $\begin{array}{l}\text { A projekt hatásainak } \\
\text { továbbgyürüzését biztosító } \\
\text { stratégia terv (Stiching the Fringe) }\end{array}$ \\
\cline { 2 - 3 } $\begin{array}{l}\text { (a döntési környezet } \\
\text { és kontextus alakítása }\end{array}$ & $\begin{array}{l}\text { Stratégia tervezés 1994 teljes } \\
\text { agglomerációra európai } \\
\text { versenyképes térség }\end{array}$ & $\begin{array}{l}\text { Thames Gateway Parklands térségi } \\
\text { stratégia }\end{array}$ \\
\cline { 2 - 3 } & $\begin{array}{l}\text { Stratégia tervezés 1998 teljes } \\
\text { agglomerációra, innovatív } \\
\text { világváros }\end{array}$ & \\
\hline
\end{tabular}




\begin{tabular}{|c|c|c|}
\hline $\begin{array}{l}\quad \text { Piac szabályozás } \\
\text { (a döntési környezet } \\
\text { paramétereinek } \\
\text { meghatározása) }\end{array}$ & - & $\begin{array}{l}\text { Építés hatósági jogkörök az ODA } \\
\text { számára való delegálása. }\end{array}$ \\
\hline \multirow{8}{*}{$\begin{array}{l}\text { (a döntési környezet } \\
\text { kereteinek } \\
\text { módosítása) }\end{array}$} & $\begin{array}{l}\text { Kisléptékü közterület felújítások az } \\
\text { önkormányzat finanszírozásában } \\
\text { '80-as évek elején }\end{array}$ & $\begin{array}{l}\text { Megújítást koordináló szevezet } \\
\text { létrehozása (ODA, majd LLDC) }\end{array}$ \\
\hline & $\begin{array}{l}\text { Nagyléptékü közparki fejlesztések } \\
\text { az önkormányzat finanszírozásában } \\
\text { '80-as évek közepétől }\end{array}$ & $\begin{array}{l}\text { Környezeti kármentesítés az } \\
\text { egykori ipari területen, } \\
\text { légvezetékek kábelalagútba } \\
\text { helyezése, szennyvízcsatorna építés }\end{array}$ \\
\hline & $\begin{array}{l}\text { PPP beruházások, zászlóshajó } \\
\text { projektek }\end{array}$ & $\begin{array}{l}\text { A terület megközelíthetőségének, } \\
\text { tömegközlekedési kapcsölatok } \\
\text { javítása }\end{array}$ \\
\hline & Barcelona Olimpia beruházás 1992 & $\begin{array}{l}100 \text { ha-os közparki fejlesztés } \\
\text { megvalósítása }\end{array}$ \\
\hline & & Lee-folyó rehabilitációja \\
\hline & & $\begin{array}{l}\text { Ingatlanfejlesztéshez terület } \\
\text { előkészítése magán beruházók } \\
\text { részére }\end{array}$ \\
\hline & & $\begin{array}{l}\text { Világszínvonalú } \\
\text { sportlétesítmények }\end{array}$ \\
\hline & & $\begin{array}{l}\text { Közterületi fejlesztések a } \\
\text { peremkerületekben az olimpiát } \\
\text { követően }\end{array}$ \\
\hline \multirow{3}{*}{$\begin{array}{l}\text { Kapacitásfejlesztés } \\
\text { (a szereplők } \\
\text { alkalmassá tétele a } \\
\text { legjobb megoldások } \\
\text { kidolgozására) }\end{array}$} & $\begin{array}{l}\text { Közösségi tervezés a Franco éra } \\
\text { utáni időszak társadalmi } \\
\text { konszenzusának kihasználásával }\end{array}$ & $\begin{array}{l}\text { Állami, regionális, városi és helyi } \\
\text { intézmények kooperációja }\end{array}$ \\
\hline & $\begin{array}{l}\text { Társadalmi részvétel a stratégiai } \\
\text { tervezésben (FAVB) }\end{array}$ & \multirow{2}{*}{$\begin{array}{l}\text { Peremkerületek együttmüködésére } \\
\text { (Leyton, Sratford, Hackeny, } \\
\text { Bromley by Bow) }\end{array}$} \\
\hline & $\begin{array}{l}\text { A Városháza és az Építészeti } \\
\text { Egyetem együttmüködése }\end{array}$ & \\
\hline
\end{tabular}

Az összevetésböl az látható, hogy a két mintaprojektben egyformán a piac élénkítési eszközök dominálnak. Barcelona esetében azonban ezzel közel azonos súllyal jelennek meg a kapacitásfejlesztés eszközei is. A piac alakítás eszközeit, a stratégia tervezést, ugyancsak mindkét mintaprojekt használta. A táblázat azt is karakteresen megerősíti, hogy a Barcelona modell megvalósításában, de talán még annál is erőteljesebb mértékben a 2012. évi londoni olimpia beruházás kapcsán a szabadtérmegújítási projektelemek nagy hangsúllyal jelentek meg.

A következő fejezet első kutatási egységében azt vizsgálom meg, hogy Budapest esetében mely eszközöket látják az interjúban megkérdezett szakemberek leginkább hasznosnak az átalakuló városi területek megújításában. 


\section{Kutatási módszer és anyag}

\subsection{A kutatási módszerek bemutatása}

A dolgozat több kutatási módszert alkalmaz a hipotézisek teszteléséhez. A 2.2. fejezetekben a vizsgálat kvantitatív felmérés és kvalitatív interjúkészítés módszerével történik, a 2.3. fejezetben elsődleges szakirodalmi források (tervdokumentumok) elemzését és kvantitatív interjúkat alkalmazok, a 2.4. fejezetben pedig az elsődleges források elemzését ismét kvalitatív interjúkkal egészítem ki.

Bryman véleménye szerint a kvantitatív kutatás a kutató által meghatározott problémákra koncentrál, míg a kvalitatív kutatás az alanyok nézőpontjait vizsgálja. Míg az előző statikus képet nyújt, a struktúrákat mutatja be, az utóbbi a folyamatokra összpontosít (Bryman 2004: 378). A kvalitatív kutatások segítséget nyújtanak ahhoz, hogy a mérhető adatok közötti kapcsolatokat, összefüggéseket feltárjuk. „Kvalitatív Interjúzás: Az információk meghallásának müvészete” címü könyvükben Herbert és Irene Rubin a módszert úgy írják le, mint olyan beszélgetést, mely során az interjúkészítő finoman irányítja a beszélgetés fonalát annak érdekében, hogy a kutatáshoz szükséges mennyiségű és mélységű információ birtokába jusson. A kvalitatív felmérés keretében készített interjúk egyediek, az adott interjúalany ismereteihez igazodnak, illetve ahhoz, hogy ismereteiböl mennyit hajlandó megosztani. (Rubin 2005:4). A kvalitatív interjúkészítési technika társadalomtudományi alapja nem a pozitivista társadalomelmélet modellt követik. A Rubinék által leírt módszer az interpretív társadalomfilozófiai megközelítést és a feminista interjúkészítési gyakorlatot hasznosítja. Az interpretív megközelítésekhez hasonlóan nem elöre meghatározott struktúrához igyekszik az eredményeket hozzárendelni, hanem rendszerét az interjúkészítés során felmerült gondolatok határozzák meg. A módszer, a feminista kutatási módszerekhez hasonlóan, nem engedi, hogy az interjúkészítő dominálja a beszélgetés fonalát. (Rubin 1995: 38). Az interjúkészítő szerepe az, hogy kellő empátiával hallgassa meg az alanya által közölni kívánt mondanivalót és rugalmasan igazítsa ehhez a beszélgetés kérdéskörét. Ennek a rugalmasságnak a biztosításához az interjúkészítőnek nem szabad visszariadnia a kutatás menetének bizonytalanságától, kellően kíváncsinak kell lennie ahhoz, hogy saját prekoncepcióit megváltoztassa a kapott válaszok alapján, és más irányba vezesse a kérdésfeltevéseit. (Rubin 1995: 41). 
Kvalitatív és kvantitatív interjúkészítés természetesen nem újdonság urbanisztikai kutatásokban. Barnamező regeneráció kapcsán ezt a módszert használja például Timothy Dixton a Temze kaputérség illetve Nagy-Manchester térségeinek projektjeit vizsgálva. (Dixgton 2007: 2379-2400). BCE Tájépítészeti doktori iskolájában is több, az utóbbi időben készített PhD dolgozat használta az interjúkészítés módszereit (Dömötör Tamás 2008., Karlócainé Bakay Eszter 2012.)

A kutatási módszer hitelességét - Rubinék ajánlása alapján - az alábbi eszközökkel igyekszik a tanulmány garantálni:

- Szakmai hitelesség: A kutatási eredmények szakmai hitelességét az interjúalanyok személye, szakmai tapasztalataik, az adott témában való kompetenciájuk garantálják.

- Átláthatóság: A felmérés alapjául szolgáló interjúk hangrögzítésre kerületek, azokról összefoglaló transzkriptek készültek, melyeket az M2-es mellékletben közlök. . Az elemzés megírása során azonban szempont volt, hogy az elemzés hangsúlya nem az interjút adó személyeken, hanem a véleményeken legyen. A 2.2. fejezetben döntően nincs hivatkozás az adott véleményt adó személyek kilétére, csupán a szakmai ágazatra, amelyben a válaszadó tevékenykedik. A 2.4. fejezetben a projektek megvalósításáról egy-egy vezető munkatársat kérdeztem meg, így ebben a fejezetben egyértelmü, hogy a válaszok kitől származnak.

- Konzisztencia: A 2.2. fejezetben kutatási eredmények értékelése és bemutatása során fontos szempont volt az egyes témakörök esetén a nem illeszkedő válaszok és vélemények áttekintése, az ellentmondások jelzése. A 2.4. fejezetben az elsődleges irodalmi forrásokban szereplő információk és az interjúk során elhangzott válaszok összevetése történt meg. Az interjúk összefüzésénél célkitűzés volt egy bizonyító erővel ható logikai rendszer összeállítása, mely az egyes véleményektől a következtetések levonásáig ível.

- Közölhetőség: A interjúkat elemző szöveg a terjedelmi korlátok figyelembevételével igyekszik kellő részletgazdagsággal, interjúk során elhangzottak esetenkénti idézésével az -----olvasmányosság és a közvetlenség szempontjainak megfelelni.

A tanulmányban alkalmazott harmadik kutatási módszer az irodalmi források elemzése. Ennek keretében elsődleges források (tervdokumentumok, internetes és hagyományos publikációk, a projekthez kapcsolódó honlapok) elemzését végeztem el a 2.3. és 2.4. Ezt a kutatási megközelítést budapesti fejlesztési dokumentumok készítésének bemutatása kapcsán már több publikáció használta (Tosics 2004: 327-346, Pallai 2010: 121-135), melyekben a szerzők egy-egy tervezési folyamatot, a folyamat szereplöit és a tervezési döntéseket mutatták be. 


\section{I. kutatási egység: Az átalakuló városi területek megújításának eszköztára.}

A településmegújítás eszközrendszerét vizsgáló interjúk alanyai a budapesti településrendezési és fejlesztési folyamatokat, a szakmagyakorlás jogszabályi és gazdasági körülményeit jól ismerő, azt meghatározó szakemberek voltak. Kiválasztásuk során fontos szempont volt, hogy az urbanisztikai folyamatok szereplöinek széles spektrumát felölelje a megkérdezettek köre. Az interjú alanyok között ezért a kormányzati intézmények vezető munkatársai (Belügyminisztérium, Budapest Főváros Kormányhivatala), önkormányzati föépítészek, településfejlesztési társaságok vezetői képviselik a közszféra szempontjait. Az ingatlanfejlesztési szektort a fővárosban jelentős beruházásokat megvalósító ingatlanfejlesztő társaságok vezető munkatársai képviselik. A tervezői szempontokat pedig a szabadtér építészettel, illetve településrendezési, településfejlesztési tervezéssel foglalkozó tervezőirodák vezetői fejtették ki. ${ }^{28}$

6. táblázat: Interjúalanyok jegyzéke a 2.2. fejezet (Hogyan ösztönözheti az állam vagy az önkormányzatok a főváros átalakuló területeinek megújulását?)

\begin{tabular}{|c|c|}
\hline Név, titulus & Munkakör \\
\hline Aczél Gábor & $\begin{array}{l}\text { Igazgatósági elnök, Városfejlesztés Zrt., MUT elnök, korábban } \\
\text { SEM IX. Vezérigazgató és igazgatósági tag, Ybl díjas építész }\end{array}$ \\
\hline Albrecht Ute & Ügyvezető igazgató, Budapest Főváros Városépítési Tervező Kft. \\
\hline $\begin{array}{l}\text { Alföldi György } \\
\text { DLA }\end{array}$ & $\begin{array}{l}\text { VIII. Kerületi Polgármester városfejlesztési tanácsadója, RÉV } 8 \\
\text { Zrt. igazgatósági tag, korábban a társaság ügyvezető igazgatója, } \\
\text { BME egyetemi docens }\end{array}$ \\
\hline Andaházy László & Ügyvezető Igazgató Panda-Pont Mérnöki Iroda Kft. \\
\hline Andor Anikó & $\begin{array}{l}\text { Müteremvezető, Land-A Táj- és Környezettervezési Müterem Kft., } \\
\text { Ybl-díjas tájépítész, }\end{array}$ \\
\hline Bardóczi Sándor & Szakújságíró, tájépítész,településrendező tervező \\
\hline $\begin{array}{l}\text { Baross Pál } \\
\text { FRICS, CRE }\end{array}$ & $\begin{array}{l}\text { BFFH Önkormányzati Vagyongazdálkodási Tanácsadó, korábban } \\
\text { ING Magyarország Fejlesztési Igazgató, RICS Magyarország } \\
\text { Elnök, egyetemi oktató BME, CEU }\end{array}$ \\
\hline Berényi András & Föépítész, Budapest IV. kerület Újpest \\
\hline Berényi Mária & Ügyvezető igazgató, Urbanitás Tervező és Tanácsadó Kft. \\
\hline Cselovszki Zoltán & Főépítész, Budapest V. kerület Belváros-Lipótváros \\
\hline $\begin{array}{l}\text { Gerzanics Annamária } \\
\text { dr. }\end{array}$ & $\begin{array}{l}\text { Főosztályvezető helyettes, BM Területrendezési és Településügyi } \\
\text { Főosztály }\end{array}$ \\
\hline
\end{tabular}

\footnotetext{
${ }^{28}$ Az interjúalanyoknak önzetlen közremüködése nélkül jelen kutatás nem készülhetett volna el. A táblázatban szereplő munkakör az interjúalanynak az interjúkészítés idején (2011. október - 2012. január) betöltött munkakörét jelzi.
} 


\begin{tabular}{|l|l|}
\hline Gyulai István & Föépítész, Budapest XIX. került Kispest \\
\hline Koszorú Lajos & Ügyvezető igazgató, Város-Teampannon Kft. \\
\hline $\begin{array}{l}\text { Hajnal István } \\
\text { MagICS }\end{array}$ & Vezérigazgató, Biggeorge's NV Zrt \\
\hline $\begin{array}{l}\text { Nagy Béla } \\
\text { dr. }\end{array}$ & Föosztályvezető, BM Építésügyi Főosztály \\
\hline Pados Gábor & Vezérigazgató, Mü-Hely Tervező és Tanácsadó Zrt. \\
\hline Radványi Gábor & Projektmenedzser, Skanska Magyarország Ingatlan Kft. \\
\hline $\begin{array}{l}\text { Sersliné Kócsi Margit } \\
\text { dr. }\end{array}$ & Fóépítész, Futureal Csoport \\
\hline $\begin{array}{l}\text { Schneller István } \\
\text { dr, CSc, }\end{array}$ & $\begin{array}{l}\text { Tanszéépítész, Budapest Főváros Kormányhivatala } \\
\text { Budapesti Főépítész }\end{array}$ \\
\hline Schuchmann Péter & Ügyvezető igazgató, Pestterv Kft. \\
\hline Szakács Barnabás & Ügyvezépítészeti Tanszék, korábban \\
\hline $\begin{array}{l}\text { Szloszjár György } \\
\text { Ügyvezető igazgató, Garten Stúdió Táj- és Kertépítész Iroda Kft. }\end{array}$ \\
\hline
\end{tabular}

Kvantitatív felmérés keretében a településmegújítás eszközeit értékelték az interjúalanyok. A felméréshez használt kérdőív az 1. számú mellékletben szerepel. A kvantitatív elemzés alapja a szerző által készített kérdőív, melyben az Adams-ék által használt eszközök „,magyarított”, a hazai urbanisztikai gyakorlatban értelmezhető konkrét példái szerepelnek. A kérdőívben 15 beavatkozási típust sorolhattak a megkérdezettek négy kategóriába. A táblázat kitöltését követően a véleményezők kiválaszthatták azt a legfeljebb három intézkedést, melynek megvalósítása esetén Budapest átalakuló területeinek megújítása terén látványos eredmények születhetnének. A kategóriák és a hozzájuk rendelt pontérték a következőek voltak:

7. táblázat: A kvantitatív értékelés pontrendszere

\begin{tabular}{|c|l|l|l|l|l|}
\hline $\begin{array}{l}\text { Mennyire segít az átalakuló } \\
\text { városrészek színvonalas } \\
\text { megújításában az alábbi } \\
\text { eszközök alkalmazása? }\end{array}$ & $\begin{array}{l}\text { Hátráltató } \\
\text { hatása van }\end{array}$ & $\begin{array}{l}\text { Nincs } \\
\text { hatása }\end{array}$ & $\begin{array}{l}\text { Kismérték } \\
\text { ben }\end{array}$ & $\begin{array}{l}\text { Jelentős } \\
\text { mértékben }\end{array}$ & $\begin{array}{l}\text { A 3 leg- } \\
\text { jelentősebb } \\
\text { beavatkozás }\end{array}$ \\
\hline ... beavatkozás & -2 pont & 0 pont & 1 pont & 2 pont & 4 pont \\
\hline
\end{tabular}

A kérdőívek értékelése során a válaszok összességének értékelése mellett, a kutatás igyekszik feltárni, hogy az urbanisztika különböző területein dolgozó szakemberek véleménye között 
kimutatható-e valamilyen karakteres véleménykülönbség. Ezért az interjúalanyok válaszait a következő csoportosításban elemzem:

8. táblázat: A kvantitatív interjúk alanyainak szakmai csoportjai

\begin{tabular}{|c|c|c|c|c|c|}
\hline $\begin{array}{c}\text { Kormányzati } \\
\text { tisztviselök }\end{array}$ & $\begin{array}{c}\text { Önkorm. } \\
\text { föépítészek }\end{array}$ & $\begin{array}{c}\text { Önkorm. } \\
\text { fejlesztési } \\
\text { társaság } \\
\text { vezetői }\end{array}$ & $\begin{array}{c}\text { Szabadtér- } \\
\text { tervezők }\end{array}$ & $\begin{array}{c}\text { Település- } \\
\text { rendezők }\end{array}$ & $\begin{array}{c}\text { Ingatlan- } \\
\text { fejlesztök }\end{array}$ \\
\hline 3 fő & 4 fö & 2 fö & 5 fö & 5 fö & 4 fö \\
\hline
\end{tabular}

A kérdőívben felsorolt beavatkozások a szerző szakmai ismereteire támaszkodva sorolták fel a városmegújítást befolyásoló eszközök meglévő és elképzelhető tárát. Ennek megfelelően a felsorolás nem tekinthető teljesnek. Létezhetnek - és amint erre a kvalitatív kutatási rész rámutatott, léteznek is - egyéb, fontos és hasznos intézkedések. Ezek számbavételét a kvalitatív interjúrész segítette. A kutatás koncepcionális eleme volt, hogy a kvalitatív felmérésre (a strukturált interjú készítésére) a kérdőív kitöltését megelőzően került sor. Így a kérdőívben foglaltak, illetve annak szerkezete nem befolyásolta az interjúalanyokat a városmegújítás eszközeinek számbavétele és rendszerezése során.

\section{II. kutatási egység: Fővárosi szabadtérmegújítási stratégiák}

Dolgozatomban a 1.2. fejezetben vázolt intézményi urbanisztikai módszerek segítségével a 2.3. fejezetben három szabadtérmegújítási stratégiának az összehasonlítását végezem el egységes szempontrendszerü, a tervezési folyamat négy kulcsfontosságú témakörére fókuszáló vizsgálattal:
a) A munka indításának háttere, a tervezés deklarált célja
b) Programalkotás módszertana
c) A társadalmi egyeztetés, a dokumentum jóváhagyása
d) Eredmények számbavétele

A Healey-féle beruházási folyamatelemezés (Healey 1992: 34-38) adaptálásával készült módszer, tervkészítés folyamatának egységes feldolgozását és ezzel összehasonlíthatóvá tételét segíti. Az vizsgált stratégiai projektek eredményeit kvantitatív interjúkkal mértem fel. A stratégia tervek projektjeinek megvalósulását a ProVerde! esetében Radnóczi Péterrel a Budapest Főváros Főpolgármesteri Hivatal Zöldfelületi Csoportvezetőjével, a Margitsziget Stratégia esetében Kövér Edit Főkert Zrt. Zöldfelület-fenntartási Igazgatóság alközpontvezetővel egyeztettem. Az AngyalZÖLD esetében a XIII. Kerületi Közszolgáltató Zrt. Környezetgazdálkodási Ágazatvezetőjeként teljes rálátásom van. 


\section{III. kutatási egység: Funkcióbővítő város-rehabilitációs projketek}

A 2.4. fejezet a KMOP 5.2.2/B pályázati kiírás keretében megvalósult beruházásokat vizsgálja tervdokumentumok felhasználásával, illetve strukturált kvalitatív interjúkkal. A vizsgálat keretében a főváros területén a pályázati kiírás keretében megvalósuló projektek közül egy kiemelt és négy nem kiemelt közterület megújítási beruházás elemzésére kerül sor az alábbi szempontok szerint:
a) Az akcióterület helye az IVS-ben
b) Az akcióterületi tervben megfogalmazott célok és elért eredmények
c) A projekt megvalósításának szervezeti kerete

A funkcióbővítő rehabilitációs projektek megvalósításával kapcsolatos interjúk alanyai a projekt megvalósítását koordináló szervezetek vezető munkatársai, illetve a projekt megvalósítás folyamatában résztvevő önkormányzati munkatársa voltak. ${ }^{29}$ Kutatásom ezen fejezetében a hangsúlyt a projekt fizikai eredményeinek vizsgálata mellett, a megvalósítás szervezeti keretére fektetem.

9. táblázat: Interjúalanyok jegyzéke a 2.4. fejezet (Funkcióbővítő város-rehabilitáció ÚMFT pályázat keretében)

\begin{tabular}{|l|l|}
\hline \multicolumn{1}{|c|}{ Név, titulus } & \multicolumn{1}{c|}{ Munkakör } \\
\hline $\begin{array}{l}\text { Berényi András } \\
\text { Nagy Elemér }\end{array}$ & $\begin{array}{l}\text { Főépítész, IV. ker. Önkormányzat } \\
\text { Müszaki ellenőr IV. ker. Önkormányzat Városüzemeltetési Főoszt. }\end{array}$ \\
\hline $\begin{array}{l}\text { Tóth Sándor } \\
\text { Török Noémi }\end{array}$ & $\begin{array}{l}\text { Kommunikációs igazgató, Budapest Szíve Kft. } \\
\text { Projektmenedzser, Budapest Szíve Kft. }\end{array}$ \\
\hline Füle Gábor & Projektmenedzser, Erzsébetváros Kft. \\
\hline Csete Zoltán & Európa belvárosa, projekt menedzser, Rév8 \\
\hline Szabó Ottó & Polgármesteri kabinet pályázati referens, XVI. ker. Önkormányzat \\
\hline
\end{tabular}

\footnotetext{
${ }^{29}$ Az interjúalanyoknak önzetlen közremüködése nélkül jelen kutatás nem készülhetett volna el. Az munkakör az interjúalanyoknak az interjú készítésekor (2012. november - 2013 május) betöltött munkakörét jelzi.
} 


\subsection{Az átalakuló városi területek megújításának eszköztára}

A 2013. évi XIX. Hild János urbanisztikai konferencia a „változás és alkalmazkodás az urbanisztikában" alcímet viselte és arra kereste a választ, hogy az utóbbi években jelentős változásokon átment magyarországi közigazgatás, az elhúzódó gazdasági válság következtében prognosztizálható külső forrásszűkülés milyen urbanisztika válaszokat tesz szükségessé, hogyan változhat, hogyan kellene változnia a hazai urbanisztika eszköztárának. (Kuslits 2013: 7).

A dolgozat jelen fejezete a fentiek szellemében, kvantitatív és kvalitatív elemzések felhasználásával kísérli meghatározni az átalakuló városi területek megújításának lehetséges eszközeit, meghatározni, hogy melyek lehetnek közülük a leginkább hatékonyak. A kvantitatív elemzés során az Adams és társai (Adams et al. 2003: 53-59) által kidolgozott, az eszközöket az ingatlanpiacra való hatásuk alapján rendszerező csoportosítást használja az elemzés.

A kvalitatív interjúk leiratai alapján készített teljes kutatási összefoglalót a dolgozat 2. számú melléklete tartalmazza. A 23 neves hazai urbanisztikai szakember megkérdezésével készült interjúsorozat összefoglalója a kutatás fontos eredményeit tartalmazza, melyek további urbanisztikai kutatásokhoz jól hasznosítható alapadatokkal szolgálnak. A dolgozat törzsanyagában ebből csak szűkebb kutatási téma szempontjából releváns, a települési stratégiákra, EU finanszírozású, illetve szabadtérrehabilitációs projektekre, valamint a rehabilitáció szervezeti kereteire vonatkozó részeket ismertetem.

\subsubsection{A fejlesztési környezetet alakító beavatkozások}

A településfejlesztés kontextuális környezetének alakítását célzó beavatkozások a kvantitatív kérdőívben egyetlen címszó alatt, települési jövőképek, koncepciók, stratégiák megalkotása szerepelt. A válaszok alapján a többség az eszközt fontosnak tartja a települési átalakuló területek megújításában (á 2,87) ${ }^{30}$ sőt, sokan a legfontosabb három eszköz közé sorolták. „Egy külföldi fejlesztö számára nem a fejlesztési kedvezmény teszi vonzóvá a területet, hanem az, ha lát egy olyan stratégiát, amihez ö illeszkedni tud” hangozott el településrendezői oldalról. Az ingatlanfejlesztők (á 1,75) ezt az eszközt kisebb jelentőségünek ítélték, bár a válaszadók véleménye megoszlott a

\footnotetext{
${ }^{30}$ A szövegben zárójelben a kvantitatív interjúk adott kérdéseire vonatkozó átlag (á), és szórás (sz) értékeket jelzem. Az adatok természetesen csak relatív összehasonlítást tesznek lehetővé. A 2 fölötti (á) értékek a jelentős, az 1 alatti (á) értékek a kevésbé jelentős beavatkozásokat jelzik a megkérdezettek véleménye szerint. A szórások esetében az 1,5 fölötti (sz) értékek jelzi az adott kérdésben erősen megoszló válaszokat, míg az 1,0 alatti (sz) értékek a kérdéssel kapcsolatos válaszok egységességére utalnak. A kérdőív eredményeinek számszerüsített összefoglalóját a 9. számú táblázat tartalmazza.
} 
jelentős hatású és a hatástalan minősítések között. Az egyik ingatlanfejlesztő szakember azt jelezte, hogy ö már belefáradt a 3-4 évente változó, ötletbörze jellegü anyagok nyomon követésén, melyekből nehezen hámozható ki karakteres fejlesztési elképzelés. Ugyancsak ingatlanfejlesztői oldalról érkező kritika volt a fejlesztési elképzelések kellő megalapozásának hiánya. De a karakteres, jól érthető és konkrétumokat tartalmazó jövőkép megfogalmazása több másik válaszadó csoport részéről is fontos, a jelenlegi dokumentumok hiányzó elemeként került említésre. A főváros „partraszállás” programjával kapcsolatban például, az egyik fóépítész riportalany annak pontos tartalmi meghatározását hiányolta. A célok megjelölése mellett az indikátorok meghatározása, melyek alapján a változások mérhetővé válnak ugyancsak felmerült szempontként. A válaszadók véleménye azonban megoszlott arról, hogy a határozott jövőkép, vagy a stratégia mögötti konszenzus - egymásnak ellentmondani tủnő - szempontjai a meghatározóbbak.

A válaszok azt jelzik, hogy a hosszútávú fejlesztési dokumentumok nem töltik be azt a funkciójukat, hogy a fővárosi településfejlesztés kontextusát meghatározzák, egyértelműsítve a település irányítás alapvető prioritásait.

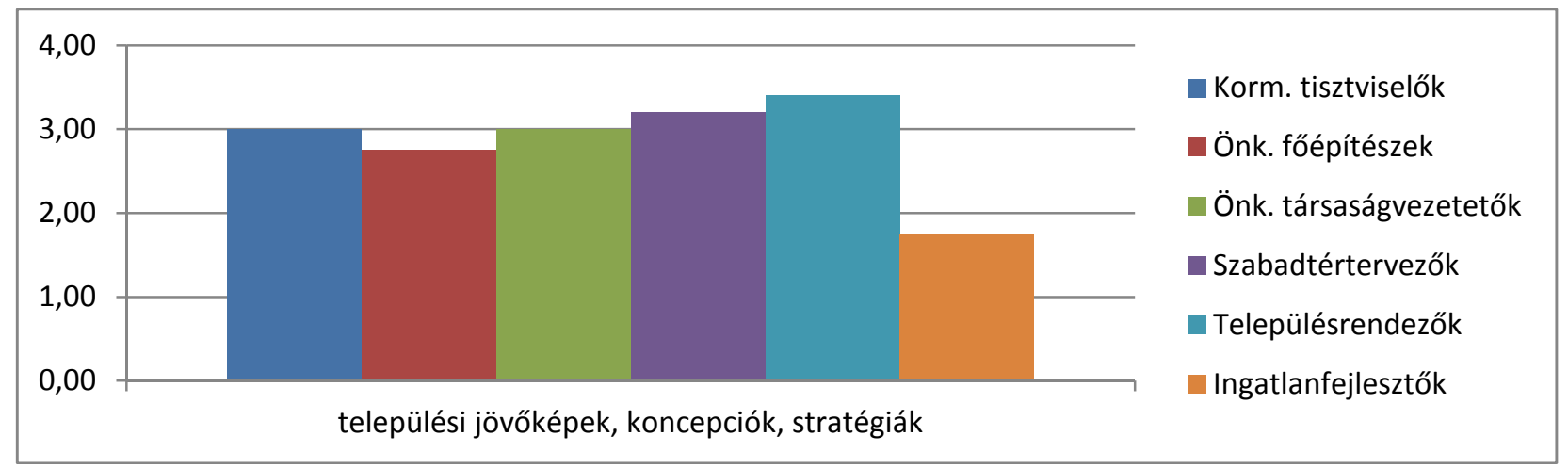

5. ábra: A fejlesztési környezetet alakító beavatkozások jelentősége interjúalanyok csoportjai szerint.

A tudatos településpolitika kialakítását a legtöbb riportalany elsődleges eszközként említette a településmegújításban. Az Integrált Városfejlesztési Stratégiák (IVS) kapcsán többen is jelezték, hogy az önkormányzatok többsége, mint az EU-s támogatások megszerzéséhez szükséges pályázati dokumentumnak tekintik. „Tíz önkormányzatból csak másfél fogja fel, hogy milyen célt szolgál valójában a városfejlesztési stratégia. A többi megcsinálja, mert ezt kérik a pályázathoz, hangzott el az egyik szabadtértervező részéről.

Ez utóbbi megállapítás rendkívül jelentős, mivel azt jelzi, hogy az építési jogszabályok által időközben a településrendezési tervezés kötelező részévé vált IVS készítése valódi célját nem tudja betölteni. Ez az eredmény a dolgozat 1. számú, a poszt-pozitivista tervezési módszerek általánossá válására vonatkozó hipotézisének ellentmond. 
A munkahelyteremtést ösztönző településpolitika, az ennek szempontjait elsődleges szempontként kezelő városfejlesztési stratégia, nagyon sok beszélgetés során szóba került, mint a városmegújítás sikerének záloga. Ennek megvalósításához volt, aki a nagy munkáltatók valamint az innovatív, kitörési pontot jelentő ágazatok bevonását hangsúlyozta a települési stratégiakészítésbe. A stratégia készítésének közigazgatási szintjét illetően többségi vélemény volt, hogy ez fővárosi szintű feladatnak kell lennie. Felvetődött azonban helyi gazdaságfejlesztési koncepció (local economy development plan) müfajának hasznossága is. Ezzel párhuzamosan nyugat-európai példákra hivatkozva, a szociális fejlesztési koncepció (social development plan) ugyancsak egy újszerü és fontos eszközként került említésre. Többen felhívták a figyelmet a fővárosi lakásállományon belül a bérlakások problematikájára. Volt vélemény, mely a szociális bérlakásokon felül, a középrétegek számára elérhető állami-önkormányzati bérlakások jelentősen csökkenthetnék a lakosság hitelállományát és növelhetnék mobilitását. Ehhez koncepcióra lenne szükség a közösségi bérlakásszektor kialakításáról, jelezte az egyik interjúalany. Egy másik megkérdezett ezt annyival toldotta meg, hogy az egész lakásszektor felújítását és fejlesztését szolgáló koncepció készítése is sürgető feladat. $^{31}$

A válaszok azt jelzik, hogy az urbanisztikai szakemberek a településfejlesztési ágazati stratégiákat és hosszú távú programokat a városi területek megújításának fontos eszközének tekintik (megerősítve a 2. számú hipotézist), elsősorban külföldi minták alapján. Természetesen a külföldön bevált példák arra nem adnak garanciát, hogy a magyarországi intézményrendszerre ezek sikeresen átültethetők.

\subsubsection{A fejlesztési környezetet szabályozó beavatkozások}

A szabályozási eszközök közül hármat említett a kérdőív. A szabályozási tervek készítését az államigazgatási munkatársak (á 2,33), illetve a fejlesztési társaságok vezetői (á 2,50) jelölték meg fontos eszközként az átalakuló területek megújításában. Az utóbbi csoportban azonban jelentős eltérés mutatkozott a két szakember véleménye között (sz 2,12). Talán meglepő módon a településrendezők voltak azok, akik a legkevésbé ítélték a szabályozási tervkészítést hasznos eszköznek (á 0,60), és ráadásul itt a vélemények szórása is igen alacsony volt (sz 0,50). De a

\footnotetext{
${ }^{31}$ Nagy-Britanniában a pénzügyminisztérium megbízásából készítette el a Kate Barker által vezetet bizottság 2004-ben a Housing Supply (Otthonteremtés) címü tanulmányt. Ennek 36 javaslata között többek közt az állami finanszírozás, adószabályozás, építésszabályozás kérdéseit érintő átfogó javaslatok szerepelnek. (Barker 2004: 1-157)
} 
fóépítészek (á 1,25), szabadtértervezők (á 1,40) és az ingatlanfejlesztők (á 0,75) is viszonylag kisebb jelentőséget tulajdonítottak ennek az eszköznek.

A kérdőív másik kérdése a müemlékvédelmi, illetve természetvédelmi területek kijelölésének eszközét vizsgálta az átalakuló területek megújítása érdekében. Ezt az eszközt a fóépítészek (á 0,75), illetve a szabadtér tervezők (á 0,40$)$ csoportja értékelte úgy, hogy kisebb mértékben segítheti a megújulási folyamatokat. A másik négy vizsgált csoport véleménye azonban az volt, hogy az eszköz kifejezetten rontja egy adott terület megújulási esélyeit. Tehát, egy terület megújítása kapcsán a meglévő értékek védelme és az beruházási költségek alacsony szinten tartása szempontjai közül a megkérdezett csoportok többségénél a költségcsökkentés bírt nagyobb jelentőséggel.

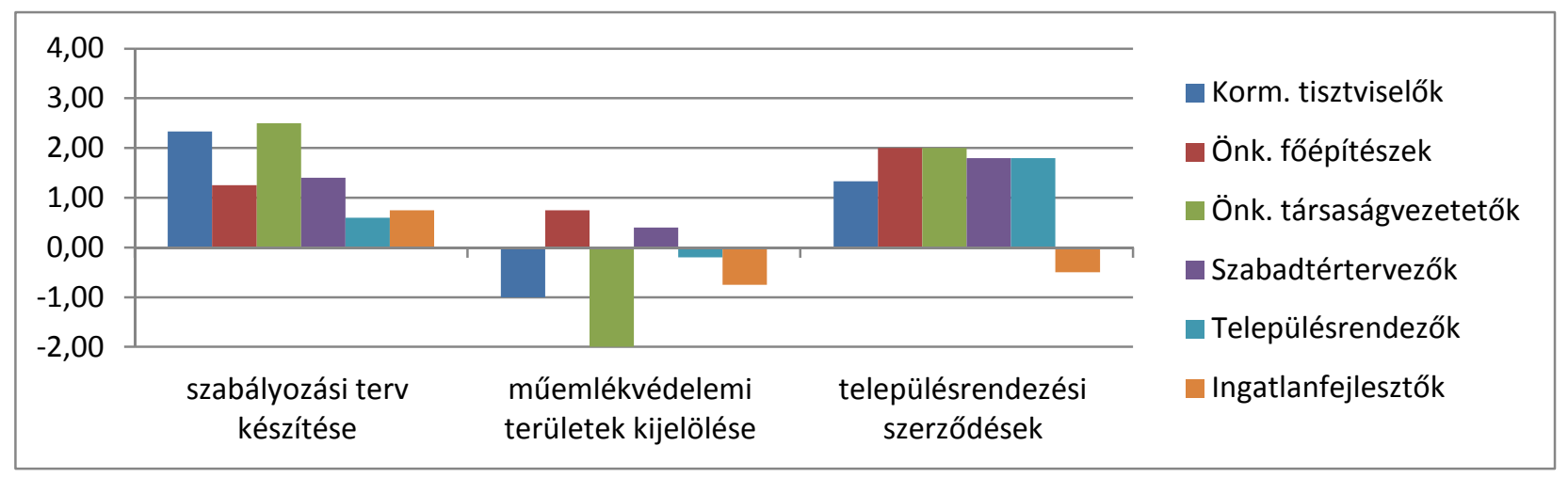

6. ábra: A fejlesztési környezetet szabályozó beavatkozások jelentősége interjúalanyok csoportjai szerint.

A kérdöív harmadik kérdése a településrendezési szerződések hasznosságára vontakozott az átalakuló területek megújításában. Ezt az eszközt az önkormányzati főépítészek (á 2,00), a fejlesztési társaságvezetők (á 2,00), a szabadtértervezők (á 1,80) és a településrendezők (á 1,80) egyaránt nagyon hasznos eszköznek tartották. Az megkérdezett ingatlanfejlesztők (á -0,50) ezzel szemben a területek megújulását hátráltató eszközként írták le. Ez utóbbi csoportnál azért azt meg kell említeni, hogy a megkérdezett négy szakemberből kettő jelezte, hogy az eszköz kifejezetten nehezíti a területek megújulását, míg másik két véleményező azt jelezte, hogy kisebb mértékben hozzájárulhat a megújuláshoz.

Számos javaslat elhangzott a kvalitatív interjúk során a szabályozási tervezés megújítására (lásd 2. számú melléklet). Ezek közöl közterületi vonatkozásai kapcsán kettőt emelek itt ki. Az egyik interjú során felmerült a szabályozási terv megvalósíthatósági tanulmánnyal történő kiegészítése. Ennek a tanulmánynak a szabályozásban meghatározott szintterületi mutatókból, beruházási költségmutatókból és a térségre jellemző ingatlanárakból kellene igazolnia, hogy a szabályozásban szereplő paraméterek racionálisak. A közterületek kialakítása kapcsán többen felvetették a közterület fejlesztési vagy közterület szabályozási terv müfaji megteremtésének kérdését. A 
közterületek kialakításának ez az eszköze a szabályozási tervek és a kivitelezési tervek közötti eszközként jöhetne létre. ${ }^{32}$

\subsubsection{A fejlesztési környezetet élénkitö beavatkozások}

A fejlesztési környezetet élénkítő eszközök közül nyolcat vizsgált a kvalitatív kérdőív. A településrehabilitációs pályázati támogatásokat az önkormányzati fóépítészek (á 0,75$)$ kivételével valamennyi megkérdezett csoport jellemzően a fontos eszközként értékelt. Leghasznosabbnak ezen belül az államigazgatásban dolgozó interjúalanyok tartották (á 2,67), míg az ingatlanfejlesztők valamivel kisebb jelentőségünek értékelték (á 1,88). Az interjúk során azonban sok kritika fogalmazódott meg a jelenleg aktuális EU forrásokra épülő pályázatokat illetően. Leginkább a pályázati keretek merevsége, bürokratikusságát említették negatívumként a válaszadók. A pályázati kiírás követelményei miatt olyan elemek is bekerülnek a pályázatokba, amiket az adott helyszín nem igényelne. „Nem a gombhoz kellene a kabátot igazítani”, utalt az egyik megkérdezett arra, hogy átgondolt fejlesztések helyett az aktuális pályázatok határozzák meg a településfejlesztési célokat. Ugyanakkor voltak vélemények, melyek szerint a pályázati kiírások az Európai Unió irányelveihez igazodva kerülnek kiírásra, és így olyan fejlesztési szempontokat is érvényesíthetnek, melyeket maguktól az önkormányzatok kevésbé tartanának fontosnak. A pályázat elbírálása során hiányzik a szakmaiság, döntően bürokratikus szempontok érvényesülnek, hangzott el egy másik kritika. Problémának jelezték, hogy engedélyezési dokumentum alapján beállított mutatókhoz ragaszkodnak mereven a pályázatértékelők. Többen jelezték, hogy nagyon fontosak a sokszor „nem kellöen produktívnak” titulált szabadtér megújítási pályázatok, hiszen járulékos hasznuk városrészre, esetenként a város egészére kiterjedő lehet. Problémaként fogalmazódott meg, hogy ezek a járulékos hasznok (új vendéglátóhelyek megjelenése, bérleti díjak emelkedése, turisztikai vonzerő növekedés) nehezen számszerüsíthetök.

A fent jelzett probléma felvetések nagyrészt visszaköszönnek a 2.4. EU-s funkcióbővítő pályázatokat bemutató fejezetben. A fejezet arra is alkalmat ad majd, hogy komplex rehabilitációs beruházások kapcsán vizsgálja (az 5. hipotézist tesztelve), hogy mennyire tartotta az adott önkormányzatok prioritásnak a szabadterek megújítását.

\footnotetext{
32 Az időközben megszületett 314/2012.(XI.8.) Korm. rendelet a településfejlesztési koncepcióról, az integrált településfejlesztési stratégiáról és a településrendezési eszközökről $27 \S$ bevezette a közterület-alakítási terv fogalmát, melynek részletes tartalmi követelményei is meghatározásra kerületek a rendelet mellékeltében.
} 
Egy adott átalakuló terület megközelíthetőségét javító beruházások valamennyi megkérdezett csoport szerint hasznos eszközei a megújításnak. A hasznosság mértékéről azonban megoszlottak a vélemények. Az ingatlanfejlesztők (á 3,50) voltak, aki leginkább, az önkormányzati főépítészek (á 1,00) azok, akik legkevésbé „szerették” ezt a beavatkozás típust. Az interjúk során többen kiemelték, hogy a Váci úti irodafolyosó létrejöttének a legfontosabb oka az út alatt haladó metróvonal. Ingatlanfejlesztői oldalról hangzott el az a kritika, hogy attól hogy egy „csomóponti terület fejlesztését bedobja [a szakmai közbeszédbe] stratégia néven az önkormányzat”, attól az még nem válik befektetésre vonzó területté. Ehhez elsősorban az adott terület megközelíthetőségét kellene megoldani.

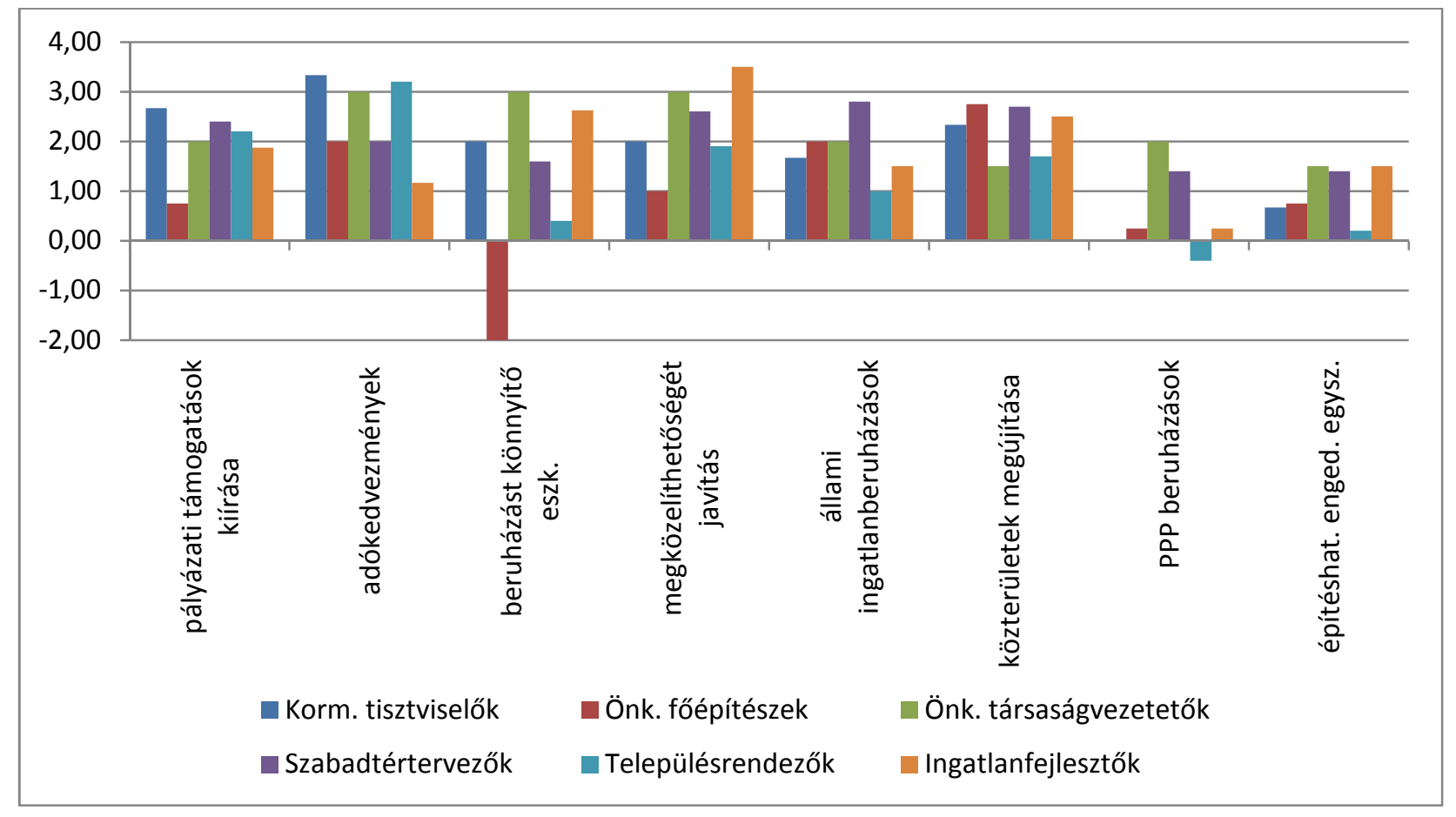

7. ábra: A fejlesztési környezetet élénkítő beavatkozások jelentősége interjúalanyok csoportjai szerint.

Az állami, önkormányzati ingatlanberuházásokat ugyancsak egyöntetủen hasznos eszköznek tartották a megkérdezettek, jelentőségük azonban megítélésük szerint kisebb. Ezt az eszköz a szabadtértervezők (á 2,80) tartották a leginkább és a településrendezők (á 1,00) a legkevésbé jelentősnek, míg az államigazgatásban dolgozó megkérdezettek véleménye között jelentős eltérések voltak (sz 2,08). Volt közülük aki ezt a típust a legjelentősebb három eszköz közé sorolta, míg másik interjúalany véleménye szerint, a fővárosi - válság időszakon kívüli - ingatlanfejlesztések arányát tekinte ezeknek nincs számottevő hatása.

A szabadterek megújítása az összes megkérdezett körében jelentős mértékben támogatott eszközként szerepelt (á 2,30). Az önkormányzati társaságvezetők (á 1,50) és a településrendezők (á 
1,70) voltak, akik valamivel kevésbé tarották az eszközt hatékonyank. Az egyik ingatlanfejlesztő riportalany jelezte, hogy a belső városrészek forgalomcsillapítási, valamint a közpark-fejlesztési beruházások olyanok, melyek egyértelmüen felértékelnek egy adott területet. Ezt a BelvárosLipótváros jelenlegi és Ferencváros volt föépítésze egyaránt megerősítette. Az előbbi a Kossuth Lajos utcát, az utóbbi Lenhossék parkot hozva fel példának arra, ahol a közterületi felújítás az ingatlanok értékét illetve a bérleti díjakat jelentős mértékben növelték. Más főépítész arra hívta fel a figyelmet, hogy a szabadtér felújítás eszköze a jelentős mértékben lepusztult területeken önmagában nem hatékony. A forgalomcsillapítás eszközével kapcsolatban a járulékos beruházások elmaradását jelölte meg problémának az egyik megkérdezett. A forgalomcsillapítás kapcsán csökkenő parkolóhelyek pótlása (parkolóházban, mélygarázsban) része kellene legyen ezeknek a felújításoknak. A közterületi felújítások előnyeként emelték ki többen, hogy az ingatlanfelújítáts összegének töredékéért megvalósítható, és eredménye a terület identitásának megerősítése révén a környező területek számára is érzékelhető változást eredményez. Több megkérdezett is jelezte, hogy a közterületi felújítások közvetetett hatásainak mérése fontos, de nem könnyü feladat. Az egyik szabadtértervező interjúalany a Green City mozgalomra hívta fel a figyelmet, mely ezeknek a közvetett hatásoknak a mérésére megpróbál objektív eszközöket kidolgozni. ${ }^{33}$ Ingatlanfejlesztő oldalról az interjúk során jelezték, hogy létezik a településmegújításnak egy kisléptékü, mozaikos verziója, amikor a területen lévő tulajdonosok újjítják meg a saját ingatlanaikat. Ezt felújítási támogatásokon kívül, kisléptékü szabadtér megújításokkal ösztönözheti az önkormányzat. Főépítészi oldalról az egyik interjúalany szintén a kisléptékü közterületi felújítások fontosságát emelte ki annak érdekében, hogy folyamatosan mozgásban legyen a településmegújítás „lennkereke”, arra utalva, hogy ezek a beavatkozások biztosíthatják, hogy a fejlesztési folyamatokban ne legyen leállás.

A kvalitatív interjúban elhangzott állítások alátámasztják a dolgozat (5. számú) hipotézisét, miszerint a szabadtérmegújítási projektek a városmegújítási folyamatok fontos katalziáló elemei lehenek.

A Public Private Partnership (PPP) a legkevésbé támogatottnak bizonyult az élénkítési eszközök között. A településrendezők (á -0,40) összességükben hátrányosnak tartották ezt az átalakuló területek megújítása szempontjából, bár a válaszok erősen megosztottak voltak (sz 1,73). Az államigazgatási munkatársak (sz 2,00), fóépítészek (sz 1,71) és ingatlanfejlesztők (sz 1,71á)

\footnotetext{
${ }^{33}$ A Green City mozgalom a Plant Pulbicity Holland, faiskolai szervezet által létrehozott lobbi mozgalom, melynek a célja a zöldfelületi fejlesztések népszerüsítése. Honlapjukon, számos kiadvánnyal igyekeznek érveket felsorakoztatni amellett, hogy a zöldfelületi fejlesztésekének milyen társadalmi, gazdasági, környezeti hasznai vannak. http://www.thegreencity.eu/ Magyar szervezettel is rendelkező hálózat akkreditációs pontrendszer kidolgozását készíti elő, ahol projektek és települések is minősíthetik magukat ökológiai szempontokból. http://www.green-city.hu/
} 
ugyancsak jelentős megosztottságot mutattak a kérdéssel kapcsolatban. Ezzel szemben a fejlesztési társaságvezetők (á 2,00, sz 0,00) egyöntetűen jelentősebbnek, a szabadtértervezők (á 1,4, sz 0,55) egyöntetủen kisebb jelentőségűnek minősítették az eszközt.

Az építési engedélyezési eljárás gyorsítása ismét olyan kérdés volt, melyet minden megkérdezett csoport hasznosnak talált, azonban jelentőségét kisebb mértékünek tartották. Az ingatlanfejlesztők (á 1,50) és az önkormányzati társaságvezetők (á 1,50) tartották az eszközt leginkább hasznosnak, míg a településrendezők (á 0,20) megítélése szerint volt ennek a legkisebb jelentősége.

\subsubsection{Kapacitásfejlesztö beavatkozások}

A kvantitatív felmérés során három kapacitásfejlesztéssel kapcsolatos eszköz szerepelt a kérdőíven. Az ingatlanpiaci információ áramlás segítését a megkérdezettek csoportjai olyan eszköznek tartották ami kisebb mértékben segíti a települések átalakuló területeinek megújulását. A főépítészek csoportja volt, amely az átlagosnál lényegesen nagyobb jelentőséget tulajdonított ennek az eszköznek (á 3,00). Itt többen a legjelentősebb három intézkedés közé sorolták az információáramlás segítését.

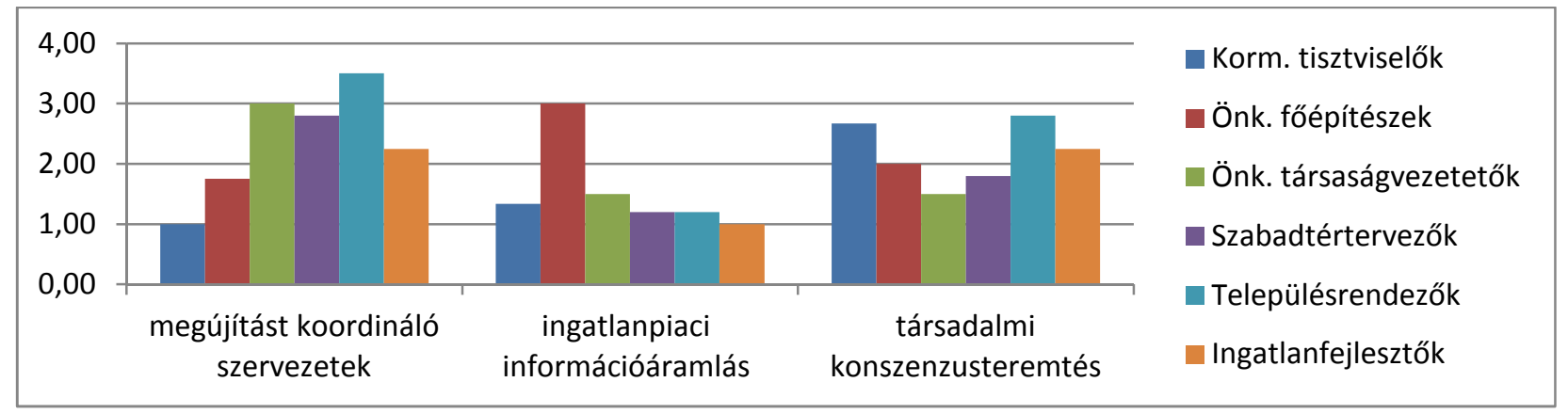

8. ábra: A kapacitásfejlesztő beavatkozások jelentősége interjúalanyok csoportjai szerint.

A következő kérdés a társadalmi konszenzusteremtésre vonatkozott a településfejlesztési célokról. A megkérdezett csoportok közül ezt leginkább a településrendezők (á 2,80) és a kormányzati tisztviselők (á 2,67) tartották fontos eszköznek. Közülük több megkérdezett a három legfontosabb intézkedés közé sorolta a konszenzusteremtést. Az eszköznek az önkormányzati társaságvezetők (á 1,50) és a szabadtértervezők (á 1,80) kisebb jelentőséget tulajdonítottak. Több megkérdezett jelezte, hogy teljes konszenzus elérése még egyszerü ügyekben is nehéz, így a teljes konszenzusra való törekvés ellehetetleníthet fejlesztéseket. Ingatlanfejlesztői oldalról az a vélemény fogalmazódott 
meg, hogy a világos és határozott településfejlesztési irány kijelölése a döntéshozók által fontosabb a társadalmi konszenzusteremtésnél.

Az adott terület megújítást koordináló szervezet létrehozása egy általánosan támogatott eszköznek bizonyult. Leginkább a településrendezők (á 3,50) tartották hasznosnak, de a fejlesztési társaságvezetők (á 3,00) és a szabadtértervezők (á 2,80) ugyancsak a legjelentősebb eszközök kategóriájába sorolták. Az ingatlanfejlesztők átlagosan ugyancsak fontos eszköznek ítélték a fejlesztéseket koordináló szervezetek létrehozását, azonban itt az eszköz hasznosságának mértékét illetően a vélemények közötti eltérés jelentős volt (á 2,25; sz 2,06). Az államigazgatási munkatársak (á 1,00) és az önkormányzati föépítészek (á 1,75) kisebb jelentőségünek tartották az eszközt. Az interjúk során azonban kiderült, hogy azok a válaszolók, akik nem tartották fontosnak ilyen szervezet létrehozását, azok közül többen úgy gondolták, hogy az önkormányzaton belül kellene ezt a feladatot ellátni. Abban egyetértés mutatkozott, hogy az önkormányzatok jelenlegi szervezeti struktúrájukban nem képesek településfejlesztés menedzsmenti feladatok hatékony ellátására. Volt azonban olyan vélemény is, hogy az önkormányzat által létrehozott szervezetekben általában a „Peter elv és a Parkinson törvény kezd müködni”. ${ }^{34}$ Volt aki Studio Metropolitánát nevezte meg, mint olyan szervezetet, ami forrás és világos felhatalmazás híján nem tudott hatékony településmenedzsmenti szervezetté válni. Más megkérdezett a Budapesti Közlekedési Központot említette, mint jó példát fővárosi szinten stratégiaalkotásra és integrálásra képes szervezetre, mely „,hivatalnokok és üzemeltetők közé visz be stratégiai gondolkodást”. A Józsefvárosi Rehabilitációs és Városfejlesztési Zrt (RÉV 8) kapcsán az a vélemény hangzott el, hogy annak hatékony müködését a vele szorosan együttmüködő ingatlanfejlesztő tette lehetővé. A Ferencvárosi Városfejlesztő Zrt. (SEM IX.) volt ezzel szemben, amely többek részéről, mint pozitív példa került bemutatásra. Az egyik ingatlanfejlesztő szerint ez a szervezet a ferencvárosi beruházási környezetet kiszámíthatóbbá tette, illetve gazdaként törekedett a felmerülő problémák megoldására. Másik válaszadó szerint az ilyen településfejlesztési szervezet az önkormányzati döntéshozatali folyamatot teszi gyorsabbá, egyszerübbé. Több válaszadó is azt jelezte, hogy professzionális városfejlesztő társaság létrehozatala fővárosi szinten lenne szükséges. A szervezet feladatait elég hasonlóan írták le a megkérdezettek. A szervezetnek a településfejlesztés irányítása lenne a fő feladata, ami azonban nem zárná ki a profit generálását, ami visszaforgatható a városfejlesztésbe. Más azt emelte ki, hogy ennek a nonprofit szervezetnek a feladata az ingatlanfejlesztések elindításának segítése lenne hangsúlyosan olyan helyszíneken, ahol a piaci szereplök segítéség nélkül nem kezdenének

\footnotetext{
${ }^{34}$ Peter elv értelmében egy szervezetben, ahol az előléptetés a sikerességen múlik, egy az alkalmazott általában azon a poszton marad leghosszabb ideig, amely ellátására már nincs kellő kompetenciája.

http://en.wikipedia.org/wiki/Peter_Principle

Parkinzon törvénye értelmében egy adminisztratív szervezetben a munkához szükséges idő kitölti az elvégzésre maximálisan rendelkezésre álló időtartamot http://en.wikipedia.org/wiki/Parkinson\%27s_law
} 
fejlesztésbe. Más válaszadó azt húzta alá, hogy az ilyen társaság segíthetné az önkormányzat és a fejlesztők közötti együttmúködést és párbeszédet, megváltoztatnák azt a gyakorlatot, hogy „,az ingatlanfejlesztő diktál”. Volt, aki ennek kapcsán azt hangsúlyozta, hogy „a településfejlesztés nem egyenlö az ingatlanfejlesztéssel”. Többen fontosnak tartották megjegyezni, hogy egy ilyen szervezetben mind tulajdoni arányban mind döntési kompetenciával az önkormányzatnak megfelelően képviseltetnie kell magát. Volt interjúalany, aki felhívta a figyelmet, hogy a köztér megújítási pályázatok kapcsán több kerület létrehozott projektmenedzsment társaságot. Az, hogy ezek mennyire látnak el átfogó stratégiaalkotó és menedzsment szervezetté, az az adott önkormányzat egyedi döntéseitől függ. Ahhoz, hogy egy ilyen szervezet tartós eredményeket érjen el, ahhoz nem projektlebonyolító, hanem hosszútávon gazdálkodó szervezetként kell müködnie, vélte az egyik megkérdezett.

A számszerüsített eredmények minden esetre alátámasztják a dolgozat (4. számú) hipotézisiét a településmenedzsment szervezet jelentőségéről a városmegújítási folyamatok megvalósításában. A 2.4. fejezet pedig részletesen vizsgálja majd azt, hogy a funkcióbővítő rehabilitációk kapcsán létrehozott társaságok mennyire váltak komplex településmenedzsment szervezetté és mennyire ágyazódtak be az önkormányzatok müködésébe.

Az interjúk során több, a kapacitásfejlesztés eszközrendszeréhez sorolható intézkedés merült fel. A javaslatok között a településrendezéssel és -fejlesztéssel kapcsolatos kompetenciák Fővárosi Önkormányzathoz történő rendelése, illetve a kibővített hatáskörü Agglomerációs Tanács létrehozása egyaránt felmerült. Elhangzott javaslat a Közmunkák Tanácsához hasonlóan, a fővárosi, állami és EU-s fejlesztési források összekapcsolására. Más vélemény szerint a Közmunkák Tanácsa helyett a mai körülményekhez igazodó, 100 ezres lakosságszámú területrészek üzemeltetésével és fejlesztésével foglalkozó menedzsment szervezetetek tudnák a proaktív tervezés feladatát ellátni. Egy másik javaslat egy összvárosi szintü és önkormányzathoz kapcsolódó tervezőiroda, kutató intézet vagy, ahogy az egyik interjúalany nevezte „agytröszt” létrehozása. Ez az intézmény nem csak a stratégiák készítésében, konkrétumokra bontásában vállalna operatív szerepet, de feladata lenne a megvalósulás nyomon követése, „a jövőkép és a valóság összevetése”. Volt, aki Bécs önkormányzatának 300 főt foglalkoztató tervezőirodáját említette mint jó példát. Főépítész részről főépítész, főmérnök, városigazgató szerepkör hármas kidolgozásában látta az egyik megkérdezett a hatékony önkormányzati menedzsment biztosítását. Más válaszadó az előző két javaslat együtteseként egy föépítész, főmérnök, főkertész és menedzser által koordinált, vétó joggal rendelkező tanácsadó testület irányítása alá szervezett tervezőirodát javasolt. Többen illették 
kritikával a kétszintü budapesti önkormányzati rendszert, mely 23 település laza szövetségeként értelmezi a várost. Volt azonban olyan vélemény is, hogy a kétszintű önkormányzati rendszer az nem ok, hanem okozat, amely a politikai megosztottságot képezi le. Ez a megosztottság, és nem a közigazgatási rendszer akadályozza, hogy a város területeinek megújításához a meglévő potenciálját kihasználja.

A témával kapcsolatos válaszok nagy száma és változatossága azt jelzi, a hazai urbanisztikai szakemberek fontos kérdésnek tekintik, hogy amilyen szervezeti struktúra segíti a településfejlesztési célok megvalósítását. A válaszok ugyancsak jelezték, hogy a városfejlesztés és a városgazdálkodás esetében a két fogalom különválása, és önkormányzati szinten szervezeti különválasztása jelenti az önkormányzatiság egyik jelentős problémáját. Hiba a fenntartási és a fejlesztési feladatok merev szétválasztása.

A lakossággal való partnerség fontossága több interjú során felmerült, mint fontos, a település megújítást segítő eszköz. Ingatlan fejlesztői oldalról ennek kapcsán a fejlesztők társadalmi felelősségvállalási tevékenysége került említésre, melyek során szponzori támogatásokkal, valamint rendezvényszervezéssel támogatnak helyi, környezettudatosságot erősítő akciókat. Településrendezői oldalról a lakosság aktív bevonását említették lakóhelyük környezetének fejlesztési kérdéseibe, illetve a fenntartás feladataiba. Az ilyen projektek kapcsán, a válaszadók véleménye szerint, a lakóhelyhez kötődés erősítése és a környezeti nevelés a fizikai megújítás mellett szintén fontos feladat. A lakosság müemlékvédelmi feladatokba való bevonására a Wekerletelepen indult oktatási programot említette az egyik megkérdezett, ahol a lakókkal tudatosítani igyekezett az önkormányzat otthonaik építészeti értékét. A civil oldal azonban önszerveződő módon is képes közterületi és zöldfelületi témák kapcsán aktivizálódni. Ennek példájára a Kortárs Építészeti Központ közösségi kert kezdeményezését említették páran, mely során a partnerség a civilek és az önkormányzat között civil kezdeményezésre alakult ki. A köztéri arculati projektekkel szemben a szociális rehabilitációs fejlesztések kapcsán említette több megkérdezett, hogy ezek során a lakóközösséggel való együttmüködés lényegesen nagyobb hangsúlyt kap, szemben a településközpont megújítási programokkal, ahol a társadalmi részvételt inkább csak kipipálandó feladatként értelmezi. A lakosság bevonásával kapcsolatban fenntartások is megfogalmazódtak. Az érintettek közönye, konszenzus kialakításának nehézsége volt az, ami a leginkább gyakori akadályként elhangzott. Ez a kettő együttesen mutatkozik meg a vezetőkben és a választókban egyaránt rögzült paternalista személetmódban. Vagyis abban, hogy a lakosok még a kisebb, a helyi közösséghez szorosan kötődő problémák megoldását az önkormányzattól várják, nem tekintik feladatuknak az ebben való aktív közremüködést. Volt riportalany, aki ezt úgy foglalta össze, hogy 
„ez az ország Kádár népe”. Az ehhez a szemlélethez kötődő, pozitivista tervezői vélemény a közterületek megújítását, mint müszaki problémát írta le, ahol a jól képzett szakember a megoldás kulcsa. „Az orvos sem kérdezi meg a pácienstől, hogy hogyan mütse”, hangzott el szabadtértervezői oldalról.

A társadalmi részvétel kérdéskörének említése egyértelmủen a poszt-pozitivista szemléletet tükröz és a 1. számú hipotézist erősíti a poszt-pozitivista tervezői szemlélet terjedéséről. Azonban az is látható, hogy a kérdéssel kapcsolatban erős kételyek is felmerülnek a megkérdezettek részéről megkérdőjelezve, hogy a budapesti (magyar) társadalom felkészült-e a társadalmi részvétellel járó felelősség vállalásra, A válaszadók részéről megjelenő pozitivista tervezői attitüd pedig egyenesen ellent mond a hipotézisnek.

10. táblázat: Az átalakuló területek megújítását segítő állami, önkormányzati beavatkozások, a kvantitatív felmérés eredményeinek táblázatos összefoglalója 35

\begin{tabular}{|c|c|c|c|c|c|c|c|c|}
\hline $\begin{array}{l}\text { Eszköz } \\
\text { típus }\end{array}$ & Eszközz & $\begin{array}{c}\text { Összes } \\
\text { megkérd } \\
\text { ezett } \\
\\
\text { átlag/ } \\
\text { szórás }\end{array}$ & $\begin{array}{c}\text { Korm. } \\
\text { tisztvisel } \\
\text { ök } \\
\\
\text { átlag/ } \\
\text { szórás } \\
\end{array}$ & $\begin{array}{c}\text { Önkorm. } \\
\text { fóépítész } \\
\text { átlag/ } \\
\text { szórás } \\
\end{array}$ & $\begin{array}{c}\text { Önkorm. } \\
\text { társaság } \\
\text { vezetető } \\
\text { átlag/ } \\
\text { szórás } \\
\end{array}$ & \begin{tabular}{|c|} 
Szabadté \\
r építész \\
átlag/ \\
szórás \\
\end{tabular} & $\begin{array}{c}\begin{array}{c}\text { Település } \\
\text { rendezö }\end{array} \\
\text { átlag/ } \\
\text { szórás } \\
\end{array}$ & $\begin{array}{c}\begin{array}{l}\text { Ingatlan } \\
\text { fejlesztő }\end{array} \\
\text { átlag/ } \\
\text { szórás } \\
\end{array}$ \\
\hline \multirow{2}{*}{ 密 } & \multirow{2}{*}{$\begin{array}{l}\text { települési } \\
\text { jövőképek, } \\
\text { stratégiák, } \\
\text { koncepciók } \\
\text { készítése }\end{array}$} & 2,87 & 3,00 & 2,75 & 3,00 & 3,20 & 3,40 & 1,75 \\
\hline & & 1,39 & 1,73 & 1,50 & 1,41 & 1,10 & 1,50 & 1,71 \\
\hline \multirow{6}{*}{ 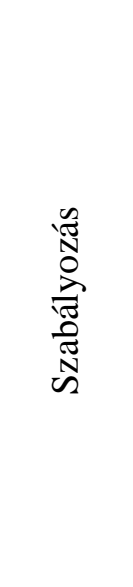 } & \multirow{2}{*}{$\begin{array}{l}\text { szabályozási } \\
\text { terv készítése }\end{array}$} & 1,30 & 2,33 & 1,25 & 2,50 & 1,40 & 0,60 & 0,75 \\
\hline & & 1,33 & 1,53 & 1,89 & 2,12 & 0,89 & 0,50 & 0,96 \\
\hline & \multirow{2}{*}{$\begin{array}{l}\text { müemlékvédel } \\
\text { mi területek } \\
\text { kijelölése }\end{array}$} & $-0,26$ & $-1,00$ & 0,75 & $-2,00$ & 0,40 & $-0,20$ & $-0,75$ \\
\hline & & 1,29 & 1,73 & 0,96 & 0,00 & 0,55 & 1,26 & 1,50 \\
\hline & \multirow{2}{*}{$\begin{array}{l}\text { településrendez } \\
\text { ési szerződések } \\
\text { kötése }\end{array}$} & 1,39 & 1,33 & 2,00 & 2,00 & 1,80 & 1,80 & $-\mathbf{0 , 5 0}$ \\
\hline & & 1,53 & 0,58 & 1,41 & 0,00 & 1,48 & 1,71 & 1,73 \\
\hline
\end{tabular}

\footnotetext{
${ }^{35}$ Színessel kiemelve azokat a kérdéseket jelöltem meg, ahol az adott válaszok értékei közötti szórás magas, ami a vélemények erős megoszlását jelzi az adott válaszadói csoporton belül.
} 
DOI: $10.14267 /$ phd.2014012

Gábor Péter: Városi területek megújítása - különös tekintettel a szabadterekre

\begin{tabular}{|c|c|c|c|c|c|c|c|c|}
\hline \multirow{16}{*}{ 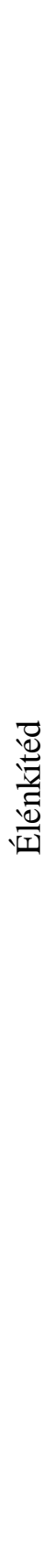 } & \multirow{2}{*}{$\begin{array}{l}\text { pályázati } \\
\text { támogatások } \\
\text { kiírása }\end{array}$} & 1,98 & 2,67 & $\mathbf{0 , 7 5}$ & 2,00 & 2,40 & 2,20 & $\mathbf{1 , 8 8}$ \\
\hline & & 1,17 & 1,15 & 1,89 & 0,00 & 0,89 & 0,50 & 0,25 \\
\hline & \multirow{2}{*}{$\begin{array}{l}\text { adókedvezmén } \\
\text { yek kialakítása }\end{array}$} & 2,43 & $\mathbf{3 , 3 3}$ & 2,00 & 3,00 & 2,00 & 3,20 & 1,17 \\
\hline & & 1,31 & 1,15 & 1,63 & 1,41 & 1,22 & 1,15 & 0,29 \\
\hline & \multirow{2}{*}{$\begin{array}{l}\text { beruházást } \\
\text { könnyítő } \\
\text { szabályozási } \\
\text { eszközök } \\
\text { kialakítása }\end{array}$} & 1,36 & 2,00 & $-2,00$ & 3,00 & 1,60 & $\mathbf{0 , 4 0}$ & 2,63 \\
\hline & & 1,77 & 0,00 & 0,00 & 1,41 & 0,55 & 1,91 & 1,60 \\
\hline & \multirow{2}{*}{$\begin{array}{l}\text { megközelíthető } \\
\text { ségét javító } \\
\text { beruházás } \\
\text { indítása }\end{array}$} & 2,28 & 2,00 & 1,00 & 3,00 & 2,60 & 1,90 & $\mathbf{3 , 5 0}$ \\
\hline & & 1,19 & 0,00 & 1,15 & 1,41 & 1,34 & 0,00 & 1,00 \\
\hline & \multirow{2}{*}{$\begin{array}{l}\text { állami ingatlan- } \\
\text { beruházások } \\
\text { indítása }\end{array}$} & $\mathbf{1 , 8 6}$ & 1,67 & 2,00 & 2,00 & $\mathbf{2 , 8 0}$ & 1,00 & $\mathbf{1 , 5 0}$ \\
\hline & & 1,32 & 2,08 & 1,41 & 0,00 & 1,10 & 0,00 & 1,73 \\
\hline & \multirow{2}{*}{$\begin{array}{l}\text { közterületek } \\
\text { megújítása }\end{array}$} & 2,30 & 2,33 & 2,75 & 1,50 & 2,70 & 1,70 & 2,50 \\
\hline & & 1,21 & 1,53 & 1,50 & 0,71 & 1,20 & 0,48 & 1,73 \\
\hline & \multirow{2}{*}{$\begin{array}{l}\text { PPP } \\
\text { beruházások } \\
\text { indítása }\end{array}$} & 0,48 & $\mathbf{0 , 0 0}$ & 0,25 & 2,00 & $\mathbf{1 , 4 0}$ & $-0,40$ & 0,25 \\
\hline & & 1,50 & 2,00 & 1,71 & 0,00 & 0,55 & 1,73 & 1,71 \\
\hline & \multirow{2}{*}{$\begin{array}{l}\text { építéshatósági } \\
\text { engedélyezés } \\
\text { egyszerúsítése }\end{array}$} & $\mathbf{0 , 9 6}$ & 0,67 & 0,75 & 1,50 & 1,40 & 0,20 & 1,50 \\
\hline & & 1,02 & 0,58 & 1,89 & 0,71 & 0,89 & 0,50 & 0,58 \\
\hline \multirow{6}{*}{ 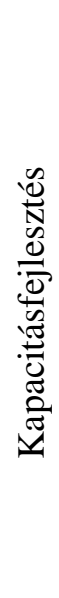 } & \multirow{2}{*}{$\begin{array}{l}\text { megújítást } \\
\text { koordináló } \\
\text { szervezetek } \\
\text { létrehozatala }\end{array}$} & 2,46 & 1,00 & 1,75 & 3,00 & 2,80 & $\mathbf{3 , 5 0}$ & 2,25 \\
\hline & & 1,51 & 1,00 & 1,71 & 1,41 & 1,10 & 0,00 & 2,06 \\
\hline & \multirow{2}{*}{$\begin{array}{l}\text { ingatlanpiaci } \\
\text { információáram } \\
\text { lás segítése }\end{array}$} & 1,52 & 1,33 & $\mathbf{3 , 0 0}$ & 1,50 & 1,20 & 1,20 & 1,00 \\
\hline & & 1,12 & 1,15 & 1,15 & 0,71 & 0,84 & 1,00 & 0,82 \\
\hline & \multirow{2}{*}{$\begin{array}{l}\text { társadalmi } \\
\text { konszenzustere } \\
\text { mtés }\end{array}$} & 2,22 & 2,67 & 2,00 & 1,50 & 1,80 & 2,80 & 2,25 \\
\hline & & 1,20 & 1,15 & 1,41 & 0,71 & 1,48 & 1,15 & 1,26 \\
\hline
\end{tabular}


A kvantitatív elemzések természetesen csak a kérdöívben szereplő beavatkozási eszközök értékelését tartalmazzák. A települések átalakuló területeinek megújítását szolgáló intézkedések teljesebb tárházát kapjuk, ha kérdőívben szereplő eszközöket, kiegészítjük a kvalitatív interjúk során elhangzott javaslatokkal. Ezt kísérli meg a következő táblázat, melyben állóbetủvel szedve a kérdőívben szereplő beavatkozási eszközök, dőltbetüs szedéssel az interjúk során felmerült eszközök szerepelnek. A táblázatban 53 beavatkozási típus szerepel melyek a fővárosi alulhasznosított területek megújításának hasznos eszközei lehetnek. Ezek közül 9 db fejlesztési környezetet alakító, 14 db fejlesztési környezetet szabályozó, 13 db fejlesztési környezetet élénkítő és 17 db kapacitás fejlesztési beavatkozást említettek az interjúalanyok .

11. táblázat: Az átalakuló területek megújítását segítő állami, önkormányzati beavatkozások összefoglalója (zárójelben az adott javaslat rövid kifejtésének helye szerepel az M2-es mellékletben)

\section{A fejlesztési környezet alakítását szolgáló eszközök}

1. települési jövőképek, koncepciók stratégiák készítése

2. munkahelyteremtésre fókuszáló stratégia (M2 p137)

3. helyi gazdasági stratégia (M2 p138)

4. helyi szociális stratégia (M2 p 138)

5. vasútrendezési koncepció (M2 p138)

6. city logisztikai koncepció (M2 p138)

7. önkormányzati, állami példamutatás (M2 p138)

8. lakás-bérlakás koncepció (M2 p138)

9. rendezési és fejlesztési kompetenciák megerösitése a fövárosi önkormányzatnál (M2 p138)

\section{A fejlesztési környezet szabályozását szolgáló eszközök}

1. szabályozási terv készítése

2. műemlékvédelmi, természetvédelmi terület kijelölése

3. településrendezési szerződés kötése

4. OTÉK módosítások (M2 p140)

5. BVKSZ átalakítása OTÉK alapúvá (M2 p141)

6. szabályozás helyett szabványok, irányelvek, szokásjog használata - az eltérések kellö szankcionálásával ingatlanfejlesztöi-önkormányzati szabályozási terv kettösének kialakítása (M2 p139)

7. szabályozási terv megvalósíthatósági tanulmánya (M2 p139)

8. szabályozási tervek tartalmi követelményeinek pontosítása, módosítása (lakás/lakosszám szerinti szabályozás; zöldfelületi normatíva bevezetése) (M2 p140)

9. közterületi szabályozási terv müfajának kialakitása (M2 p141)

10. ingatlan értéknövekedési adó, srófadó, betterment adó (M2 p142)

11. karbon lábnyom adó bevezetése (M2 p142)

12. jó minöség garancia a tenderterv készítésekor (M2 p143)

13. ipari társasházi szabályozás a PTK-ban az ipari területek tulajdonviszonyainak rendezése érdekében (M2 p143)

14. építési moratórium a rozsdaövezeten kívüli beépítetlen területekre (M2 p143) 


\section{A fejlesztési környezet élénkítését szolgáló eszközök}

1. településrehabilitációs pályázat támogatások kiírása

2. adókedvezmények bevezetése

3. beruházást könnyítő szabályozási eszközök kidolgozása

4. állami, önkormányzati ingatlan (épület) beruházások megvalósítása

5. szabadterek megújítása

6. PPP beruházások megvalósítás

7. építéshatóság engedélyezés egyszerüsítése, gyorsítása

8. iparüzési adó kerületeknél hagyása (M2 p142)

9. ÁFA mentesség a müemléki épületek felújítása esetén (M2 p144)

10. az ingatlan értéktöbblet adón belül kedvezmény biztosítása a rozsdaövezeti beruházások számára (M2 p144)

11. müemlék védelmi kötelezettségekhez kapcsolt pályázati támogatások rendszere

12. szabadtér megújitási pályázati támogatások (M2 p144)

13. társasház megújitási pályázati támogatások (M2 p147)

\section{Kapacitásfejlesztést szolgáló eszközök}

1. az ingatlanpiaci információ áramlás segítése

2. társadalmi konszenzusteremetés a fejlesztési célokról

3. az adott terület megújítását koordináló szervezet létrehozása

4. ajánlás készités a müemlék védelem és a müemlék jövedelemtermelö képességének növelésének összekapcsolásáról (M2 p141)

5. EU finanszírozású szabadtér megújitások tapasztalatait összefoglaló kutatás elvégzése, eredmények hasznosítása (M2 p147)

6. föépítész-fömérnök-fökertész-településigazgató szerepkörök megteremtése az önkormányzatoknál (M2 p149)

7. minőségi ingatlanfejlesztöi képzés megvalósítása (M2 p149)

8. képviselöi, hivatalnoki továbbképzések szervezése (M2 p149)

9. szakmai érdekképviseletek müködtetése, együttmüködése (M2 p149)

10. fejlesztők társadalmi felelösségvállalása (M2 p150)

11. lakosság aktív bevonása a tervezési, fenntartási folyamatokba (M2 p150)

12. civil kezdeményezések iránti fogadókészség (pl. közösségi kertészkedés) (M2 p150)

13. összvárosi stratégiaalkotó tervezöiroda, ,agytröszt” (M2 p149)

14. fóvárosi professzionális városfejlesztési társaság létrehozatala (M2 p148)

15. kibövített hatáskörü agglomerációs tanács (M2 p139)

16. EU-s, állami és önkormányzati forrásokat és döntési kompetenciákat egyesítös szervezet (Közmunkák Tanácsa) (M2 p139)

17. közmüszolgáltatók hatósági és szolgáltató szerepkörének különválasztása, egységes és ingyenesen hozzáférhetö közmüadatbázis létrehozatala (M2 p146)

Budapest átalakuló területei megújításának fenti gazdag - teljesnek nyilván nem tekinthető eszköztára jelzi, hogy témával kapcsolatos urbanisztikai kutatásoknak dolgozatom keretein messze túlmutató tartalékai vannak. A fejezetben leírtak összefoglalóját a dolgozat formai követelményeinek megfelelően a 3. eredmények fejezet részeként közlöm. 


\subsection{Fővárosi szabadtérmegújítási stratégiák}

Az előző fejezetből kitűnt, hogy a településfejlesztési - integrált, vagy ágazati - stratégiákat a megkérdezettek az átalakuló városi területek megújításának leghasznosabb eszközének tekinti. A települési környezet élhetősége, a fenntarthatóság szempontjainak településfejlesztésbe való átültetése érdekében szükséges, hogy a települési zöldfelületi rendszerekkel és zöldhálózatokkal városi léptékü tervezés keretében foglalkozzunk (Szilágyi 2012:124) Ezek alapján, dolgozat második kutatási egységében az átalakuló területek megújításának széles eszköztárából a szabadtérmegújítási stratégiák elemzésére kerül sor. Három esettanulmányon keresztül vizsgálom, hogy az egyes tervdokumentumok milyen szervezeti struktúrában kerültek kidolgozásra, illetve mennyire sikeresek a saját maguk által megfogalmazott célok megvalósításában.

A vizsgálódás tárgya három budapesti szabadtérépítészeti stratégiai dokumentum készítésének folyamata és az elért eredményei.

1. Pro Verde! Budapest Zöldfelületi Rendszerének Fejlesztési koncepciója és programja 2006.

2. Margitsziget Stratégiai Terve, 2008.

3. AngyalZÖLD, Budapest XIII. kerületi Önkormányzat zöldfelület fejlesztési koncepciója és zöldhálózat fejlesztési programterve 2008-2011.

A dokumentumok kiválasztásának elsődleges indoka, hogy ezek a tervdokumentumok müfaji újdonságot jelentettek készítésük időszakában, hiszen korábban nem készültek átfogó stratégiák Budapest zöldfelületi- zöldhálózati rendszerének fejlesztésére, készítésükre semmilyen jogszabály, irányelv, illetve pályázati kiírás nem kötelezte a megbízókat. A választás további oka, hogy a dolgozat írója valamennyi stratégiai alkotás során része volt a kidolgozó csapatnak, és így a tervezés folyamatáról közvetlen tapasztalatai vannak.

\subsubsection{Pro Verde!}

A munka indításának háttere, a tervezés deklarált célja

A dokumentum a BFFH Környezetvédelmi Ügyosztályának megbízásából készült el a Stúdió Metropolitana Kht koordinálásában. Bár a dokumentum nem nevezi magát stratégiának, a bevezetője szerint: „Az alábbi koncepció és program célja az, hogy olyan széleskörü társadalmi egyetértéssel, fenntartható rendszerben megfogalmazott jövőkép, illetve annak alapján olyan stratégiai program kerülhessen elfogadásra, amely integrált, akcióorientált megközelítésével megalapozza a konkrét, finanszírozható fejlesztési projektek megvalósitását mind rövidebb, mind 
pedig hosszabb távra, illeszkedve a Fövárosnak a Podmaniczky Program megvalósításával összefüggö rendszeréhez.” (5. old). A dokumentum összeállításában egy tízfös szakmai munkacsoport vett részt, melyben a tájépítész mérnökök többségben képviseltették magukat. ${ }^{36}$

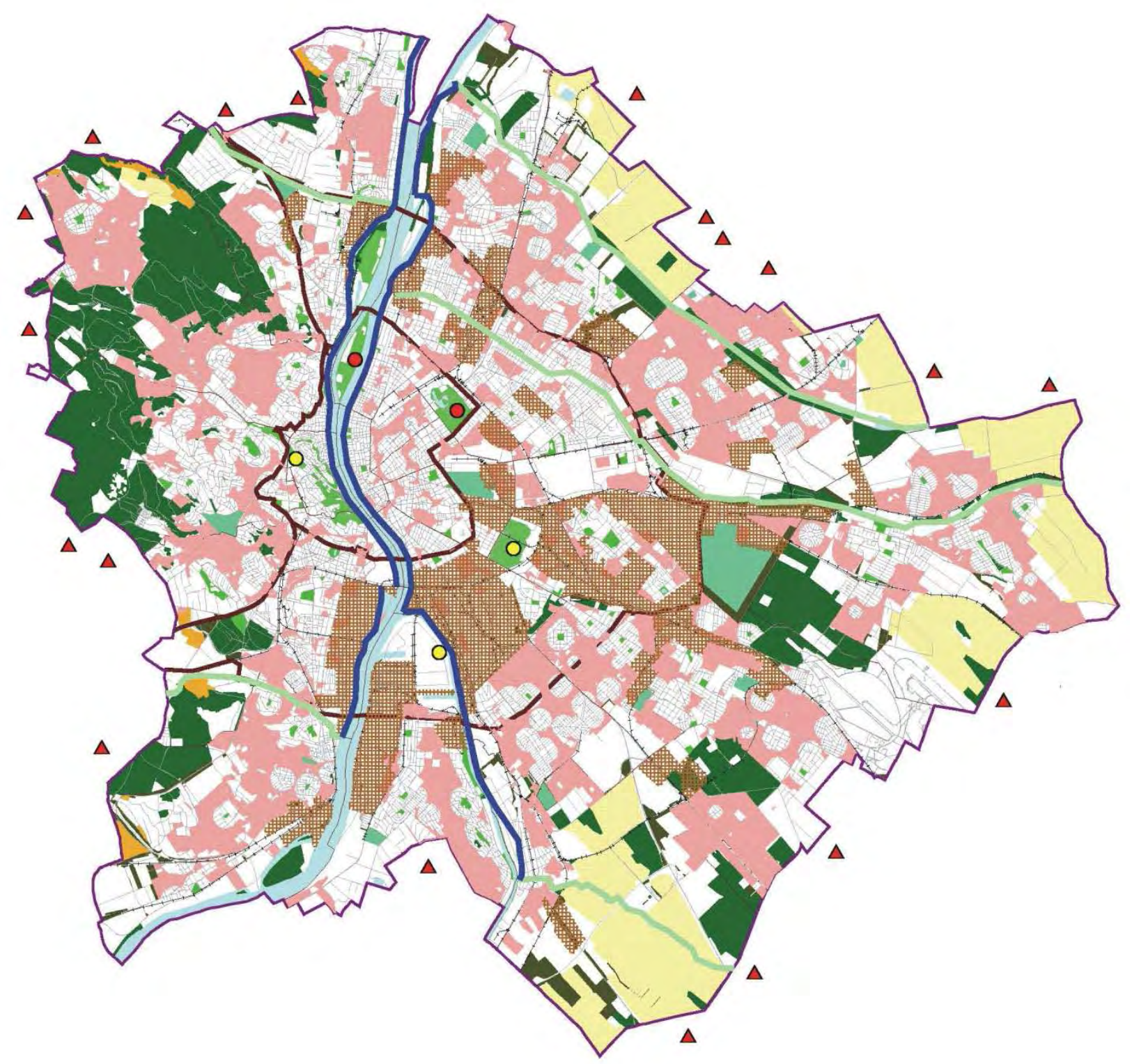

9. ábra: ProVerde!, zöldfelületi területfelhasználási egységek és javasolt fejlesztési projektek.

\section{$\underline{\text { Programalkotás }}$}

A dokumentum 5. fejezetében a vizsgálati megállapítások - nem pontosan követhetö felhasználásával határozza meg a fővárosi zöldfelületi rendszer problémáit, majd csoportosítja

\footnotetext{
${ }^{36}$ A munkacsoport tagja: Ongjerth Richárd megbízotti koordinátor, Bardóczi Sándor, Berczelédiné Shalaby Kinga, Gábor Péter, Iványi György, Kovácsné Papp Katalin, Dr. M Szilágyi Kinga, Dr. Nagy Katalin, Pataki Károly, Somogyi Réka voltak.
} 
ezeket. A problémák alapján pedig átfogó majd részletesebb programokat határoz meg. Ezt követően kerül sor a dokumentumban a fejlesztések négy prioritásának meghatározására:

- Zöldfelület tudatosság erősítése.

- A pozitív érdekviszonyok kialakulásának elősegítése.

- A városi élet zöldfelületi élettereinek megörzése, fejlesztése.

- A zöldfelület fejlesztés hátterének szakmai, politikai megalapozása.

A stratégiai programalkotás logikájának ellentmond, hogy a fejlesztés prioritásai a problémák alapján történő célmeghatározást követően kerül csak dokumentálásra. Ezt tekinthetnénk szerkesztési hibának is, azonban a folyamat résztvevőjeként állítom, hogy ez a munkamódszerből következő logikus eredmény. A dokumentumkészítő szakértő csoport ugyanis minden felmerült problémára tett megoldási javaslatot. Vagyis nem kerültek egyes szempontok, illetve problémák kiemelésre, priorizálásra. Ezt a feladatot a társadalmi, politika egyeztetés folyamata láthatta volna el. A tervezési módszer egyértelmüen pozitivista megközelítést tükröz; a szakértő csoport a vizsgálatot követően gyakorlott orvosként ajánl megoldásokat a feltárt bajokra. Ennek alapján a dokumentum címében szereplő „koncepció” elnevezés teljes mértékben indokolt.

\section{A társadalmi egyeztetés, a dokumentum jóváhagyása}

Az egyeztetési dokumentáció elkészültét követően a társadalmi egyeztetetés rendkívül szük határidővel, az érintettek igen szük körének megkeresésével történt. Ezzel a lebonyolítók tulajdonképpen a szabályozási tervek társadalmi egyeztetésének magyarországi gyakorlatát alkalmazták. A Stúdió Metropolitana kiküldte a dokumentációt a mértékadónak ítélt társadalmi szervezetek részére, a BFFH Környezetvédelmi Ügyosztálya pedig mindössze egy tervegyeztető fórumot szervezett 2006. július 13-án délelőtt 10 órakor a városháza dísztermében. Az időpontválasztást a véleményezők több kifogással is illették. Az egyeztetés kapcsán nyolc írásos vélemény érkezett, a fórumon 33-an jelentek meg véleménynyilvánítás céljából. A dokumentummal kapcsolatban kapott észrevételek jellemzően pozitívak voltak, fontosnak ítélve a főváros törekvését zöldhálózat fejlesztési koncepció megalkotására. A dokumentum ilyen rendkívül szűkre szabott társadalmi egyeztetésnek indoka a megbízó részéről az volt, hogy az önkormányzati választásokat megelőző őszi közgyülési időszakban szerette volna a koncepciót elfogadtatni. A megbízó a stratégia dokumentumok mögötti társadalmi konszenzus megteremtését nem tekintette elsődleges szempontnak.

A BFFH Környezetvédelmi Ügyosztályának eredeti célkitüzésének ellenére a dokumentum nem került önálló határozatként a képviselő testület elé. Az egy évvel később kidolgozott Fővárosi 
Környezetvédelmi Program felülvizsgálata során a dokumentum vizsgálati részei és javaslatai, csökkentett tartalommal mégis csak testületi jóváhagyásra kerületek az 1931/2007. (11.29) Fővárosi Közgyülési határozatban. A két időpont között társadalmi egyeztetés a program zöldfelületi rendszer fejlesztésének céljairól gyakorlatilag nem történt.

\section{Eredmények}

A Pro Verde! dokumentum közvetlen eredményeinek mérése a benne megfogalmazott programok és projektek megvalósulásának áttekintésével vehető számba. A prioritások rendszeréhez igazodva a dokumentum kilenc programot és 58 projektet határozott meg, melyek közül kiemelte a legjelentősebb, a pillér üzenetét hordozó ún. „zászlóshajó projektetek”. A projektek és megvalósulásuk felsorolását a 3. számú melléklet tartalmazza. A számszerủ eredmények igen haloványak. Megvalósultnak egy projekt tekinthető (sótlanítási kampány). Részben megvalósult, illetve folyamatban lévő projektek száma hét (12\%), míg a meg nem valósult projektek száma 50 $(86 \%)$.

A számok önmagukban kudarcot jeleznek. Ezt a negatív képet tovább erősíti, ha figyelembe vesszük, hogy a zászlóshajó projektek közül gyakorlatilag egy sem valósult meg, illetve az is tudható, hogy a megvalósult, vagy részben megvalósult projektek alapvetően nem a Pro Verde! dokumentáció hatására valósultak meg, hanem független döntéshozatali folyamat eredményeként. Mindazonáltal a Pro Verde! dokumentum úttörő, müfajteremtő szerepe nem vitatható el. A későbbi szabadtérfejlesztési stratégiák ennek eredményeinek, módszereinek figyelembevételével készültek el. A dokumentum elemző részeként készült multispektrális ürfelvételek elemzésével készült zöldfelület intenzitás változását bemutató részt pedig későbbi több hazai és nemzetközi terv és publikáció használta alapadatként.

\subsubsection{Margitsziget Stratégia}

\section{A munka indításának háttere, a tervezés deklarált célja}

A stratégia terv készítését a Fővárosi Közgyülés határozta el 2008 februárjában, felkérve a Főpolgármestert, hogy az érintettek és érdekeltek bevonásával készíttessen tervet a Margitsziget értékmegőrző jövőképe meghatározásához. A határozat értelmében kiemelt figyelmet kellett fordítani az uniós források felhasználásával megvalósítható fejlesztésekre. ${ }^{37}$

\footnotetext{
${ }^{37}$ A Fővárosi Közgyülés 238/2008. (02.28.) határozata. Előterjesztő: Hagyó Miklós, Felelős szervezeti egység: Környezetvédelmi Ügyosztály, Előterjesztés címe: Javaslat a Margitsziget védelmére. Határidő: 2008.09.30.
} 


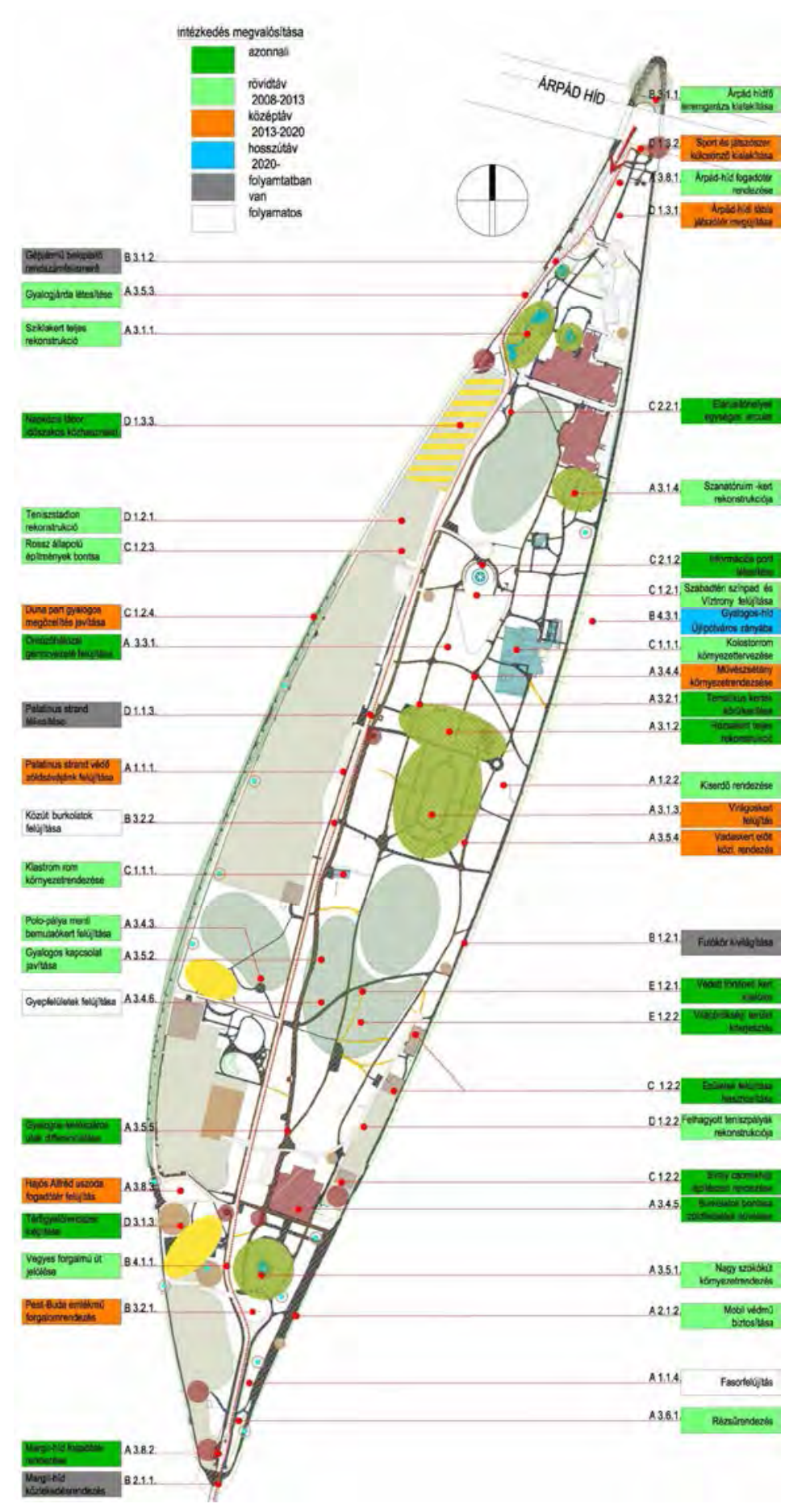

10. ábra: Margitsziget Stratégia, javasolt projektek és ütemezésük
A dokumentum szerint „stratégia készítésének célja megtalálni az egyensúlyt a terület széleskörü társadalmi használatának és az épített és természeti környezet színvonalas fenntartásának olykor egymással ellentétes szempontjai között.” (8. old.) A dokumentum leírása szerint a készítés egyik indoka, hogy hiányzik a sziget üzemeltetésével foglalkozó intézmények és az érintett fővárosi önkormányzati ügyosztályok fejlesztési elképzeléseit integráló, az ellentétes fejlesztési szándékokat ütköztető, az ellentmondásokat feloldó dokumentum. A dokumentum összeállítására Budapest Főváros Főpolgármesteri Hivatal (BFFH) Környezetvédelmi Ügyosztályától a Főkert Nonprofit Zrt kapott felkérést. A Főkert Zrt a munkába a Főkert Tervezési Stúdió Kft-t, a Budapest Főváros Városépítési Tervező (BFVT) Kft. és a Zöldfa Stúdió Kft-ket vonta be.

\section{$\underline{\text { Programalkotás }}$}

A dokumentum a 2.7. fejezetében tartalmazza az egyes témakörök szerinti SWOT analízist (73-90 old.) Az elemzés készítése a dokumentum kidolgozói és a Főkert, a Margitsziget fenntartását koordináló munkatársai közös munkacsoporti megbeszélésein került sor. A rendkívül részletes elemzés célja a vizsgálati eredmények átfogó összefoglalása és a problémák és lehetőségek részletes bemutatása. Ezt követően kerül sor, egy probléma fa - célfa rendszerben a tennivalók meghatározására. A SWOT analízis és a Probléma struktúrában szereplö elemek közötti kapcsolatot dokumentumból nem 
követhető nyomon. A problémák és célok meghatározásánál szintén nem derül ki a dokumentumból, hogy mely javaslatok kerültek tervezői javaslatként, melyek az egyeztetések eredményeként megfogalmazásra. A dokumentum, a Pro Verde!-hez hasonlóan deduktív programalkotási módszert alkalmaz, minden problémához felsorolva egy - és csak egy - a kidolgozók által legmegfelelőbbnek ítélt tennivalót. Ezt a deduktív logikát a következő fejezet némileg megbontja, felsorolva azokat a témaköröket, ahol egy adott kérdés kapcsán eltérö döntési alternatívák, vagy ahogy a dokumentum fogalmaz „ágazatok közötti konfliktusok” merültek fel. A fejezet a prioritás és programalkotást megelőlegezően meg is jelöli, hogy az egyes alternatívák közül melyeket javasolja megvalósításra. A dokumentum 3. fejezete (105-108. old.) határozza meg a fejlesztési prioritásokat, cselekvési célkitüzéseket és a stratégiai jövőképét. A dokumentumban megfogalmazott prioritások:

- A sziget tájépítészeti, építészeti értékeinek megőrzése és fenntartása.

- A hagyományos kulturális, rekreációs, sport és turisztikai funkciók minőségi fejlesztése.

- A sziget használatának fenntartható pályára állítása.

A dokumentum ötödik fejezete (113-138. old) a korábban megfogalmazott stratégiai döntéseket és cselekvési célkitüzéseket bontja ki részletesebben és megvalósítási időtávot rendel az egyes tennivalókhoz. A fejezet, a dokumentum munkaközi, ügyosztályi egyeztetésre készített verziójában a megvalósítási időtávon túlmenően a megvalósításért felelős önkormányzati ügyosztályt is megnevezte volna. Azonban a Környezetvédelmi Albizottság 2009. január 26-i ülésén, ügyosztályi kezdeményezésre ez kikerült a dokumentációból. A stratégia az egyes döntési alternatívák vázolásával már egyértelmüen használja a poszt-pozitivista tervezési módszertant. A megfogalmazott célokhoz vezető projektek megvalósításának szervezeti keretét, a megvalósítás felelöseit azonban a megbízó munkatársa (ügyosztályvezetők) nem engedték szerepeltetni a dokumentumban, nyilvánvalóan a többlet feladatok elhárítása céljából. A megbízónak nem volt célja a stratégia megvalósítást hatékonyan koordinálni képes szervezet létrehozása, vagy meglévő szervezet felruházása ezzel a feladattal, annak ellenére, hogy ezt az intézkedést a dokumentum maga is javasolja.

\section{A társadalmi egyeztetés, a dokumentum jóváhagyása}

A dokumentum „Marketing és kommunikációs feladatok” fejezete javaslatokat tartalmaz a stratégia társadalmi kommunikációjára. A javaslatok döntően egyirányúak, az érintettek tájékoztatását célozzák meg a Stratégiai tartalmáról. Bár a stratégiai készítést elrendelő önkormányzati határozat 2008. februárjában megszületett, a dokumentum összeállítása csak július folyamán kezdődött meg, a dokumentáció összeállításának határideje 2008. szeptember vége volt. Ez a rendkívül rövid 
határidő, mely ráadásul a nyár végi - szabadságok által érintett időszakra esett - a megbízó értékelése alapján, nem tette lehetővé, hogy a dokumentációt megelőző időszakban széles körben egyeztetéseket folytassanak a készítők. A rendelkezésre álló időkeret arra bizonyult elegendőnek, hogy a BFFH érintett ügyosztályaival történjen egyeztetés a munkaközi dokumentáció elkészítését megelőzően. A munkaközi dokumentáció 72 szervezet számára került kiküldésre véleményezés céljából. Ezek között a BFFH szervezeti egységei, az érintett kerületi önkormányzatok, minisztériumok, államigazgatási szervezetek, fővárosi szervezetek, fővárosi önkormányzati tulajdonban lévő társaságok, a szigeten müködő vállalkozások illetve fővárosi kérdésekben mérvadónak ítélt civil szervezetek szerepeltek. Ezen túlmenően 2008. szeptemberében sor került egy egyeztetési fórumra is, melyen a szervezeteket képviselö megjelent 25 fő mondhatta el véleményét az egyeztetési dokumentációról.

Az egyeztetési folyamat eredményességét illetően a kép jóindulatúan szemlélve is ellentmondásos. Kedvezőnek tekinthető, hogy a BFFH szervezeti egységeinek többsége, azok melyek a Margitsziget fejlesztésével és üzemeltetésével kapcsolatban leginkább érintettek voltak, részt vettek az egyeztetési folyamatban. Ennek révén a dokumentum a BFFH-n belüli érdekeket és elképzeléseket képes volt összefoglalni. Az érintett négy kerületi önkormányzat közül kettő tartotta érdemesnek álláspontjának kifejtését a tervezés keretében. A szabályozási tervek véleményezése kapcsán érintett államigazgatási szervezetek döntő többsége nem reagált a megkeresésre. Vélhetően ennek oka az, hogy a dokumentum müfaja ismeretlen volt a szervezetek előtt, így nem tartották feladatuknak a véleménynyilvánítást. Ugyancsak kívül maradtak az egyeztetésen a megkeresett fővárosi szervezetek illetve a fővárosi tulajdonban lévő társaságok döntő hányada. Az érme másik oldala azonban az, hogy a Margitszigettel kapcsolatban jelentős mértékben érintett, a terület jövőjével kapcsolatban elképzelésekkel rendelkező szervezetek részt vettek részletes véleményükkel a folyamatokban. A területen érintett vállalkozások közül több, föként a kisebb cégek részt vettek a folyamatokban. Ennek oka kettős. Egyrészt voltak társaságok melyek remélték, hogy olyan fejlesztések történhetnek, melyek számukra új piacot nyitnak. Mások részvételének indoka az volt, hogy tartottak a számukra kedvezőtlen döntések megszületésétől. A civil szervezetek részéről volt talán a legszembetünőbb a passzivitás. Az egyik távolmaradó szervezet telefonos egyeztetés során kifejtette, hogy nem látják annak garanciáit biztosítva, hogy javaslataikat kellő súllyal mérlegelik majd a dokumentum összeállítói. Korábbi kedvezőtlen tapasztalataik miatt tartottak attól, hogy meghívásuk a folyamatba csak formális, azért hogy a készítők „kipipálhassák” a civil szervezetek részvételétre vonatkozó passzus. A dokumentum alapján meg kell állapítani, hogy ez a félelem nem volt alaptalan. 


\section{Eredmények}

A Fővárosi Közgyülés 184-186/2009. (02.26.) határozatában foglalkozott a Stratégiai Tervvel. A közgyülés elé a terv rövidített összefoglalója, valamint az ez alapján készült három oldalas határozati javaslat került. A határozati javaslat a dokumentáció 4. fejezete alapján készült, azonban nem nevezte meg a sziget fejlesztésének a dokumentációban szereplő hármas prioritását. Az alátámasztó dokumentumban szereplő 23 kulcsfontosságú döntés közül 15 épült be a képviselőtestületi határozatba.

Amennyiben a megvalósult projektek száma alapján próbáljuk a stratégia eredményességét értékelni, az eredmény vegyes. A megfogalmazott 107 javaslat közül 76 esetében (71\%) nem kezdődött még meg a megvalósítás. 23 esetében (21\%) pedig részben valósultak meg a javaslatok, vagy a megvalósulás még folyamatban van. Nyolc javaslatról mondható el (7\%), hogy a stratégiában megfogalmazottak értelmében maradéktalanul megvalósult. Azonban az eredményeknek létezik egy másfajta olvasat is. A közgyűlési határozat értelmében a szigetre vonatkozó KSZT elfogadását követően kerül sor az „ütemezett fejlesztési javaslatokat tartalmazó fejlesztési intézkedési terv” kidolgozására. Ez vélhetően az addig kinevezésre kerülő „megfelelő eszközökkel felruházott” Margitsziget gondnokság feladata lesz. Így tekinthetjük úgy, hogy jelenleg a Stratégia elkészítése és az intézkedési terv kidolgozása közötti átmeneti időszakban vagyunk.

A stratégia négy éves pihenőt követően a Margitsziget stratégiai terve, fejlesztési terv néven ismét a Fővárosi Önkormányzat asztalára került. A dokumentum a korábbi terv részbeni átvételéve határozza meg az főváros Margitszigettel kapcsolatos fejlesztési céljait. Sőt, a városvezetés ezek közül három látványos beruházást 2013. nyaráig meg is valósított (nagy szökőkút átépítése, Szabadtéri Színpad és Víztorony felújítása, Rózsakert rekonstrukciója). A dokumentum az egyes projektek esetében hol részletes, hol kevésbé részletes költségvetést is tartalmaz. A dokumentumban jelzett fejlesztési célkitüzések 25 milliárd Ft összeget tesznek ki (vélhetően bruttó összegben). A dokumentumban szereplő 25 program között három új, a korábbi dokumentumban nem szereplő program található (lóvasút kiépítése, kisállatkert fejlesztése, szobrok környezetének rendezése), illetve egy program ellentmondásban áll a korábbi stratégiában megfogalmazottakkal (északi parkolóterület bővítése). A dokumentum kizárólag beruházási jellegű feladatokat fogalmaz meg, fenntartásról, sziget menedzsment felállításáról nem esik benne szó. 


\subsubsection{AngyalZÖLD}

A munka indításának háttere, a tervezés deklarált célja

Az AngyalZÖLD Stratégia a XIII. Kerületi Környezetgazdálkodási Kft által - a Zöldfa Stúdió Kft. közremüködésével - kidolgozott dokumentum. A cég a kerületi önkormányzat tulajdonában lévő nonprofit társaság, mely a kerületi kezelésben lévő zöldterületek és zöldfelületek fenntartásáért, illetve köztisztasági és hulladékgazdálkodási feladatok elvégzésérért felelős. A stratégia elkészítésére nem jogszabály, vagy önkormányzati döntés kötelezte a társaságot. A cégvezetés saját belátásából döntött a stratégia megalkotása mellett. A cégvezetés céljai a következők voltak a stratégia megalkotásával:

- Az Önkormányzati feladatokat ellátó, komplex környezetgazdálkodási feladatokat végző társaság átfogó jövőképének, értékrendjének, prioritásainak deklarálása mind az egyéb önkormányzati szervezetek, mind az érintett lakosság számára.

- A társaság által végzett széles körü tevékenységek jól áttekinthető rendszerbe szervezése.

- A korlátozott anyagi források tervszerü és ütemezett felhasználásának segítése, az ad hoc, esetenként egymásnak ellentmondó beruházási igények problémájának mérséklése.

- Új, hatékony kommunikációs platform kialakítása az érintettekkel.

\section{$\underline{\text { Programalkotás }}$}

A dokumentum összeállítása a Környezetgazdálkodási KNKft. munkatársai és a Zöldfa Stúdió Kft. szoros együttmüködésében történt meg. Ennek keretében a helyzetfeltárás eredményeire alapozottan készült témakörönként elvégzett SWOT elemzés készíti elö a problémákat és az ezek alapján meghatározott célokat tartalmazó táblázatot (31-32. old.) A 2008-as dokumentáció pozitivista hozzáállását jelzi, hogy a SWOT analízis, a problémafa-célfa struktúra, illetve a projekt struktúra címeit a készítők igyekeznek azonos címszavakon szerepeltetni, ezzel jelezve, hogy a folyamat egy egységes deduktív logika alapján határozza meg a tennivalókat. A 2011-es felülvizsgálati dokumentumban apró különbségek mutatják az induktív programalkotás tényének felvállalását. Egyrészt a jövőkép és prioritások fejezete megelőzi a problémafa - célfa táblázatot. Másrészt célok és problémák rendszerét bemutató táblázat jelentős mértékben egyszerűsödött, célja inkább a jövőképben foglaltak táblázatos bemutatása, és nem a vizsgálati munkarész megállapításainak számbavétele. A 2008-as munkafolyamat során a programalkotás alapja a Környezetgazdálkodási Kft. meglévő programjainak rendszere volt, mely átstrukturálásra, illetve kiegészítésre került. A 
készítők számára nem volt kérdéses, hogy a munka eredményeként a meglévő müködési keretekhez igazodni kell, lehetővé téve azok új elemekkel történő kiegészítését.

A megfogalmazott prioritások a következőek:

- Szükséges a kerületi közhasználatú zöldfelületek mennyiségi és minőségi fejlesztése, a fenntartás színvonalának javítása.

- A zöldfelületek fenntartásával és fejlesztésével kapcsolatos társadalmi együttmüködést erősíteni, szélesíteni, a gazdasági és szabályozási környezetet javítani kell.

A prioritások a társaság tevékenységének egészét lefedik, nem határoznak meg igazi, belső prioritásokat. A 2011-es dokumentum készítése során éppen ezt a hiányosságot igyekezett a közterületek minőségi felmérése pótolni, egy skóciai módszer adaptálásával meghatározva a beavatkozást leginkább igénylő zöldterületi helyszíneket. (Gábor 2010: 20-33). A dokumentumok hat program keretében határozzák meg a jövőkép eléréséhez szükséges tennivalókat. Bár a 2008-as dokumentumban a programoknál még csak címszavakban jelennek meg az egyes projektek, ennek ellenére, már ez a dokumentáció is tartalmazza az egyes programok becsült éves forrásigényét. Ennek alapja a Környezetgazdálkodási KNKft. müködése során a korábbi évek során kialakult éves forrásigény volt. A 2011-es dokumentum esetében az egyes projektek részletesebben, tartalmukban vázlatosan kifejtve, megvalósítás tervezett határidejével és becsült forrásigénnyel együtt szerepelnek. A 2011-2014 közötti időszak zöldhálózat fejlesztési és fenntartási programjainak összes forrásigényét a készítők 4058 millió Ft-ra taksálták (37. oldal).

\section{A társadalmi egyeztetés, a dokumentum jóváhagyása}

A dokumentum készítése során a témakörért felelős alpolgármesterrel, illetve a Főépítészi Irodával többszöri egyeztetés történt. Az önkormányzati cégek és osztályok számára az egyeztetési dokumentációt véleményezésre megküldték, érdemi észrevételek azonban nem érkeztek. A civil és szakmai szervezetek részéről nagyobb aktivitás mutatkozott a véleményezésre. A dokumentáció az érintett önkormányzatok számára is megküldték, melyek közül az újpesti és a fővárosi önkormányzatok reagáltak a levélre.

A beérkező vélemények alapvetően támogatták a kerületi kezdeményezést, kiegészítéseket, javaslatokat füzve a részletekhez. A lakossági egyeztetés az önkormányzatoknál megszokott módon, lakossági fórum keretében történt. A 2008. április 30-i rendezvényen 18 érdeklődő vett részt, és mondta el ugyancsak alapvetően támogató, kiegészítéseket tartalmazó észrevételeit, 
lakóhelyükhöz kapcsolódó fejlesztésekkel kapcsolatos fejlesztési igényeit. Érdemi különbséget a társadalmi egyeztetésben a 2008-as készítés és a 2011-es felülvizsgálat során, az időközben kialakított interaktív honlap és facebook oldalak jelentettek potenciálisan. Ezeken az új kommunikációs felületeken szintén volt a lehetőség a véleményezésre. Azonban a platformot csak igen kevéssé vették igénybe, a fórumokon a témával kapcsolatban mindössze öt véleményező írt bejegyzést.

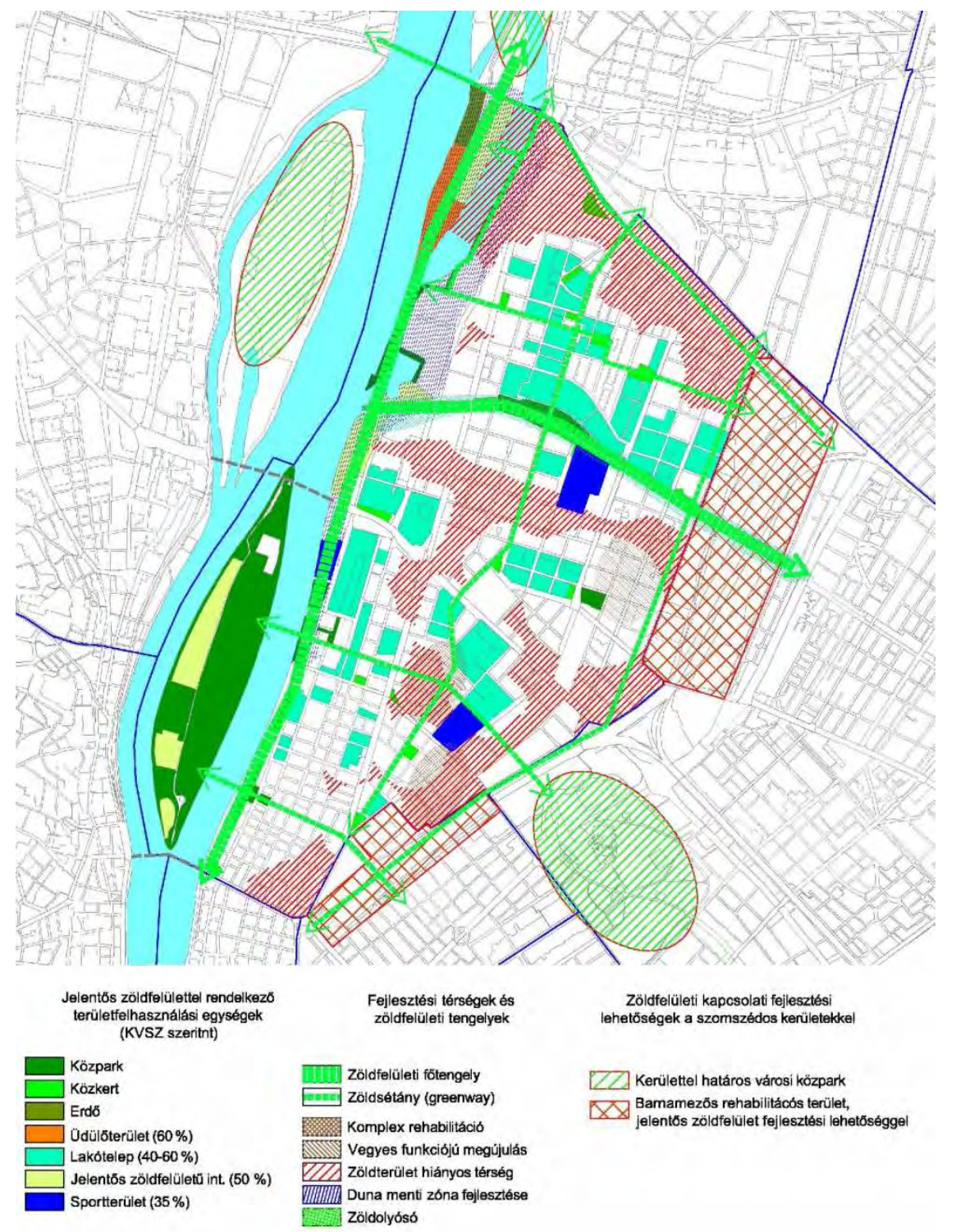

11. ábra: AnagyalZÖLD, zöldhálózat fejlesztési tengelyek

\section{Eredmények}

Az AngyalZÖLD Stratégia 2008-as elfogadását követően a XIII. Kerületi Környezetgazdálkodási KNKft. müködési alapdokumentumává vált. A társaság üzleti tervei, projektjei ennek rendszeréhez igazodva kerültek kidolgozásra. A kerületi önkormányzat képviselőtestülete 87/2008.(VI.26.) önkormányzati határozatával fogadta el az eredeti dokumentumot, majd 109/2011.(VI.30) határozatával a felülvizsgálatot. A társaság 2010 júliusában készített beszámolót a Stratégia 
megvalósítás addigi eredményeiről. 2013. júniusában a dokumentumban megnevezett 79 projektből 21 esetében mondható el, hogy teljes egészében megvalósult (27\%), 41 esetében (52\%) folyamatban volt a megvalósítás illetve folyamatos környezetgazdálkodási programot tartalmaz. 17 olyan projektje van a dokumentumnak, amely kapcsán még nem történt érdemi elörelépés (15\%). A közvetlen kimeneti eredmények mérésén túl, a megismételt lakossági közvéleménykutatások lehetővé teszik, hogy a munka valódi társadalmi eredményét mérje az önkormányzat. Ennek alapján állítja a dokumentum, hogy a kerületi közparkok, játszóterek lakossági megítélése 2008 és 2011 között kilenc, illetve tizenegy százalékponttal javult (46. old.)

Ugyancsak a Stratégia készítés eredményének, illetve következményének tekinthetők azok az újszerủ programok és projektet, melyek 2008-at követően jelentek meg a Környezetgazdálkodási KNKft tevékenységében. Ilyen az angyalzold.hu interaktív honlap, illetve a stratégia facebook oldala. A társadalmi partnerségre való nagyobb hangsúly eredményeképpen valósult meg az Országbíró lakótelep közösségi tervezéssel elkészült szabadtérépítészeti koncepcióterve, illetve kerülnek megvalósításra a lakóközösségeket, társasházakat, civil szervezetek és vállalkozásokat a környező zöldfelületek fenntartásba bevonni szándékozó programok.

2012. februárjában a XIII. Kerületi Környezetgazdálkodási KNKft. beleolvadt az akkor megalakuló XIII. Kerületi Közszolgáltató Zrt-be. Ennek szervezetén belül a környezetgazdálkodási tevékenységek mellett a közútkezelői és parkolási rendszer üzemeltetési feladatokat végző Közterületi Divízió alakult. A feladatok integrációját követően várható, hogy a stratégia 2014-ben esedékes felülvizsgálatakor a zöldhálózat fejlesztési feladatok mellett a közlekedés fejlesztési, forgalomtechnikai célkitüzéseket is integráló stratégia fog készülni.

A három stratégia dokumentum ,eredményességének” vizsgálatára hasznos eszköz számba venni, hogy a bennük javasolt projektek jelenleg hol tartanak a megvalósításában. (A stratégiákon belüli projektjavaslatok részletes bontása szerinti értékelést a 3. számú melléklet tartalmazza) ${ }^{38}$ :

\footnotetext{
38 A stratégia tervek projektjeinek megvalósulását a ProVerde! esetében Radnóczi Péterrel a Budapest Főváros Főpolgármesteri Hivatal Zöldfelületi Csoportvezetőjével, a Margitsziget Stratégia esetében Kövér Edit Főkert Zrt. Zöldfelület-fenntartási Igazgatóság alközpontvezetővel egyeztettem. 2013. júliusában. Segítségüket köszönöm. Az AngyalZÖLD esetében a XIII. Kerületi Közszolgáltató Zrt. Környezetgazdálkodási Ágazatvezetőjeként a projektek megvalósulásáról naprakész információm vannak. A táblázat adatai itt is a 2013. júliusi állapotot mutatják.
} 
12. táblázat: A szabadtérmegújítási stratégiákban javasolt projektek megvalósulási aránya (2013. júliusi állapot)

\begin{tabular}{|l|c|c|c|c|c|c|}
\hline \multirow{2}{*}{ megvalósulás } & \multicolumn{2}{|c|}{ Pro Verde! } & \multicolumn{2}{c|}{$\begin{array}{c}\text { Margitsziget } \\
\text { Stratégia }\end{array}$} & \multicolumn{2}{c|}{ AngyalZÖLD } \\
\hline & $\mathbf{d b}$ & $\mathbf{\%}$ & $\mathbf{d b}$ & $\mathbf{\%}$ & $\mathbf{d b}$ & $\mathbf{\%}$ \\
\hline megvalósult & 2 & 3 & 10 & 9 & 36 & 33 \\
\hline folyamatban & 2 & 3 & 9 & 8 & 39 & 49 \\
\hline részben megvalósult & 13 & 22 & 14 & 13 & 5 & 6 \\
\hline nem valósult meg & 41 & 71 & 74 & 69 & 22 & 28 \\
\hline Összesen & $\mathbf{5 8}$ & $\mathbf{1 0 0}$ & $\mathbf{1 0 6}$ & $\mathbf{1 0 0}$ & $\mathbf{9 4}$ & $\mathbf{1 0 0}$ \\
\hline
\end{tabular}

Ugyancsak tanulságos összefoglalni, hogy az egyes dokumentumok milyen eszközöket javasolnak az általuk vizsgált szabadterek fejlesztéséhez, megújításához.

13. táblázat: A szabadtérmegújítási stratégiákban javasolt projektek típusai

\begin{tabular}{|c|c|c|c|c|c|c|}
\hline \multirow{2}{*}{$\begin{array}{c}\begin{array}{c}\text { javasolt projektek } \\
\text { típusai }\end{array} \\
\text { típus } \\
\text { (Adams féle } \\
\text { csoportosítás szerint) }\end{array}$} & \multicolumn{2}{|c|}{ Pro Verde! } & \multicolumn{2}{|c|}{$\begin{array}{l}\text { Margitsziget } \\
\text { Stratégia }\end{array}$} & \multicolumn{2}{|c|}{ AngyalzÖLD } \\
\hline & db & $\%$ & db & $\%$ & db & $\%$ \\
\hline $\begin{array}{l}\text { további koncepcionális } \\
\text { tervezés } \\
\text { (alakítás) }\end{array}$ & 6 & 11 & 5 & 5 & 0 & 0 \\
\hline $\begin{array}{l}\text { ellenőrzés } \\
\text { (szabályozás) }\end{array}$ & 13 & 23 & 17 & 16 & 6 & 6 \\
\hline $\begin{array}{l}\text { beruházás } \\
\text { (élénkítés) }\end{array}$ & 14 & 25 & 59 & 56 & 49 & 52 \\
\hline $\begin{array}{l}\text { fenntartás } \\
\text { (élénkítés) }\end{array}$ & 3 & 5 & 8 & 8 & 24 & 26 \\
\hline $\begin{array}{l}\text { finanszírozási } \\
\text { (élénkítés) }\end{array}$ & 4 & 7 & 3 & 3 & 0 & 0 \\
\hline $\begin{array}{l}\text { kommunikáció } \\
\text { (kapacitásfejlesztés) }\end{array}$ & 11 & 19 & 9 & 8 & 3 & 3 \\
\hline $\begin{array}{l}\text { partnerség } \\
\text { (kapacitás fejlesztés) }\end{array}$ & 6 & 11 & 5 & 5 & 12 & 13 \\
\hline Összesen & 57 & 100 & 106 & 100 & 94 & 100 \\
\hline
\end{tabular}

A három stratégia közül az AngyalZÖLD az, amely a legnagyobb számban és arányban tartalmaz közösségi partnerséget ösztönző, azaz poszt-pozitivista szemléletet tükröző projektet. Ezek között több megvalósult, illetve folyamatban lévő van. 
14. táblázat: Az AngyalZÖLD stratégiában megjelenő partnerségi programok.

\begin{tabular}{|c|c|c|}
\hline Program neve & tartalom & megvalósulás \\
\hline $\begin{array}{l}\text { Program a kulturált } \\
\text { ebtartásért }\end{array}$ & $\begin{array}{l}\text { Kommunikációs és konzultációs program a } \\
\text { felelős városi kutyatartás népszerüsítésének } \\
\text { eszközeiről. }\end{array}$ & folyamatban \\
\hline $\begin{array}{l}\text { Oktatási intézmények } \\
\text { ökológiai lábnyomának } \\
\text { csökkentése }\end{array}$ & $\begin{array}{l}\text { Szelektív hulladékgyűjtés és komposztálás } \\
\text { az iskolákban. }\end{array}$ & nem indult el \\
\hline $\begin{array}{l}\text { Lakossági részvétel a } \\
\text { közterületek tervezésében }\end{array}$ & $\begin{array}{l}\text { Országbíró lakótelep közterületi felújítása } \\
\text { közösségi tervezéssel }\end{array}$ & megvalósult \\
\hline $\begin{array}{l}\text { Lakossági zöldfelület } \\
\text { védnökségi pályázat }\end{array}$ & $\begin{array}{l}\text { Társasházak elötti közterületek védnökségbe } \\
\text { adása }\end{array}$ & $\begin{array}{l}10 \text { éve zajló } \\
\text { program }\end{array}$ \\
\hline $\begin{array}{l}\text { Lakossági zöldhulladék } \\
\text { gyüjtés }\end{array}$ & $\begin{array}{l}\text { Együttmüködési program a családi házakban } \\
\text { keletkező zöldhulladék komposztálására. }\end{array}$ & folyamatban \\
\hline Társasház udvar program & $\begin{array}{l}\text { A legzöldebb társasházi udvar díjazása, } \\
\text { jópéldaként való bemutatása. }\end{array}$ & $\begin{array}{l}\text { 2013-ban } \\
\text { másodszor került } \\
\text { kiírásra }\end{array}$ \\
\hline Zöldhomlokzat program & $\begin{array}{l}\text { A legszebb erkély és zöldhomlokzat } \\
\text { díjazása, jópéldaként való bemutatása. }\end{array}$ & $\begin{array}{l}\text { 2013-ban } \\
\text { másodszor került } \\
\text { kiírásra }\end{array}$ \\
\hline Közösségi kertprogram & $\begin{array}{l}\text { Önkormányzati üres telek közösségi kertként } \\
\text { való hasznosítása. }\end{array}$ & nem indult el \\
\hline $\begin{array}{l}\text { Önkéntes munka } \\
\text { közterületeken }\end{array}$ & $\begin{array}{l}\text { Kerületi vállalkozásokkal való } \\
\text { együtttmüködés a közterülete szépítéséért. }\end{array}$ & $\begin{array}{c}\text { folyamatos } \\
\text { program }\end{array}$ \\
\hline Közterületi szponzoráció, & $\begin{array}{l}\text { Lehetőség teremtése kerületi vállalatoknak } \\
\text { közterületi fenntartás szponzorálására }\end{array}$ & nem indult el \\
\hline $\begin{array}{l}\text { Intézménykertek a } \\
\text { környezeti } \\
\text { szemléletformálásért }\end{array}$ & $\begin{array}{l}\text { Intézménykertek megnyitása közösségi } \\
\text { használat számra }\end{array}$ & 3 megvalósult példa \\
\hline $\begin{array}{l}\text { Vendéglátó terasz } \\
\text { program }\end{array}$ & $\begin{array}{l}\text { A legszebb kerületi vendéglő terasz számára } \\
\text { közterület használati díjkedvezmény } \\
\text { biztosítása. }\end{array}$ & $\begin{array}{l}\text { idén meghirdetett } \\
\text { pályázat }\end{array}$ \\
\hline
\end{tabular}

A fejezetben leírtak összefoglalóját a dolgozat formai követelményeinek megfelelően a 3 . eredmények fejezet részeként közlöm. 


\subsection{Funkcióbővítő város-rehabilitációs projektek}

A dolgozat harmadik kutatási egysége a hipotézisek tesztelése céljából vizsgálja, a KMOP 2007. 5.5.2/B „Funkcióbővítő rehabilitáció, Budapesti integrált városfejlesztési program, Budapesti kerületi központok fejlesztés” címü pályázat keretében megvalósult projekteket. A vizsgálat az intézményi urbanisztikai elemzések szellemében a rehabilitációs projektek megvalósításának szervezeti keretének vizsgálatára helyezi fókuszát.

A 2007-2013-as EU programozási időszakban, a magyar kormány az Új Magyarország Fejlesztési terv (ÚMFT) Közép-Magyarországi Operatív Program 2007. 5.5.2/B „Funkcióbővítő rehabilitáció, Budapesti integrált városfejlesztési program, Budapesti kerületi központok fejlesztés” címü pályázat keretében lehetett vissza nem térítendő támogatást nyerni alulhasznosított településrészek megújítására. A pályázati kiírás értelmében a pályázat kiírói „olyan városközpont és településközpont megújítást kívánnak elösegíteni, amelyek célja a központok gazdasági, kulturális, turisztikai ... funkcióinak erösítése” (KMOP 5.5.2/B pályázati kiírás: 4) A kiírás célja általánosságban a helyi önkormányzatok innovatív település-rehabilitációs akcióinak ösztönzése. A pályázat keretében az átalakuló városi terület megújítása szempontjából alábbi releváns célkitüzések szerepeltek:

- „új gazdasági és közösségi funkciók megjelenésének támogatása, a meglévő funkciók erösítése,

- kulturális, építészeti és turisztikai értékek feltárása és megőrzése

- kiskereskedelmi funkciók erösítése

- vonzó városi környezet kialakítása, mely ösztönzi a további magánberuházásokat"

- „ „települési vonzerö növelése közösségi es gazdasági funkciók ösztönzésével;

- a városi vonzerö, illetve a belváros és a kerületközpontok vonzerejének növelése funkcióbövítö fejlesztéssel;

- központi térrel nem rendelkezö települések, illetve kerületek esetében a város/kerületidentitásának erösítése;

- a város központi részein szolgáltatási funkciók erösítése;

- fizikai környezet minöségének javítása a városi vonzerö növelésével;

- városszerkezeti problémát okozó barnamezös területek, alulhasznosított vagy felhagyott ipari területek, volt katonai objektumok rehabilitációja, funkcióváltás útján történö hasznosítása; 
- funkcióváltás megvalósítása es városi funkciók gazdagodásának ösztönzése”

A pályázati támogatás lehetőséget nyújtott mind az épületekhez kapcsolódó (épület felújítás, bővítés, létesítés, örökségvédelem), mind a szabadtereket érintő (közterület rendezés, örökségvédelem, közlekedés szervezés) építési tevékenységek megvalósítására (KMOP 5.5.2/B pályázati kiírás: 10).

A pályázatok kötelező mellékletét képezték az érintett önkormányzat által készített Integrált Városfejlesztési Stratégia (IVS) és az adott területre vonatkozó Akcióterületi Terv (ATT) dokumentumok. Ezeket a pályázati kiírás szerint az NFGM által készített „Városfejlesztési Kézikönyv tartalmi útmutatásai alapján kellett összeállítani.” (KMOP 5.5.2/B pályázati kiírás: 90).

15. táblázat: A KMOP 2007. 5.5.2 pályázati kiíráson támogatást nyert fővárosi projektek. ${ }^{39}$

\begin{tabular}{|c|c|c|c|c|c|c|}
\hline & KMOP 5.5.2 pályázat címe & $\begin{array}{c}\text { Projekt } \\
\text { gazda }\end{array}$ & $\begin{array}{l}\text { Támogat } \\
\text { ási } \\
\text { összeg } \\
\text { mill. Ft. }\end{array}$ & $\begin{array}{c}\text { Projekt } \\
\text { összeg } \\
\text { bruttó } \\
\text { mill. Ft }\end{array}$ & $\begin{array}{c}\text { Támogat } \\
\text { ási arány } \\
\text { \% }\end{array}$ & $\begin{array}{c}\text { Akció } \\
\text { terüle } \\
\text { t } \\
\text { nagys } \\
\text { ág } \\
\text { ha }\end{array}$ \\
\hline 1 & $\begin{array}{l}\text { Budapest Szíve Program - Hídföterek } \\
\text { és új pesti korzó kiépítése, I. ütem }\end{array}$ & BFFH & 1633 & 2237 & 73 & 36,1 \\
\hline 2 & $\begin{array}{l}\text { Budapest Szíve Program - } \\
\text { Reprezentativ kaputérség kiépítése, } \\
\text { I. ütem }\end{array}$ & BFFH & 2647 & 3268 & 81 & 19,4 \\
\hline 3 & $\begin{array}{l}\text { Belváros új főutcájának kiépítése - I. } \\
\text { ütem }\end{array}$ & V. ker. & 1931 & 5517 & 35 & 48,9 \\
\hline 4 & $\begin{array}{l}\text { Bel-Buda kerületrészének } \\
\text { funkcióbővítő rehabilitációja }\end{array}$ & II. ker. & 987 & 1352 & 73 & 51,2 \\
\hline 5 & Nagyvárosi jövő - Új Fötér & IV. ker. & 770 & 1027 & 75 & 11,0 \\
\hline 6 & $\begin{array}{l}\text { "Kultúra utcája" Budapest, } \\
\text { Erzsébetváros funkcióbővítö } \\
\text { rehabilitációja }\end{array}$ & VII. ker. & 832 & 1053 & 79 & 9,0 \\
\hline 7 & $\begin{array}{l}\text { Budapest Európa Belvárosa } \\
\text { Kulturális-gazdaság Fejlesztési } \\
\text { Program, Józsefváros Palotanegyed }\end{array}$ & VIII. ker. & 899 & 1665 & 54 & 68,2 \\
\hline 8 & $\begin{array}{l}\text { MOM - Gesztenyéskert kulturális, } \\
\text { sport és szabadidő negyed } \\
\text { funkcióbővítő fejlesztése }\end{array}$ & XII. ker. & 900 & 2571 & 35 & 32,4 \\
\hline 9 & $\begin{array}{l}\text { Sashalom városközpont komplex } \\
\text { városrehabilitációja }\end{array}$ & XVI. ker. & 686 & 1163 & 59 & 236,8 \\
\hline 10 & $\begin{array}{l}\text { "Térnyerö - Újítsuk meg együtt } \\
\text { Keresztúr köztereit!" }\end{array}$ & $\begin{array}{l}\text { XVII. } \\
\text { ker. }\end{array}$ & 936 & 1463 & 64 & 41,4 \\
\hline 11 & Wekerle, ahol értéket őriz az idő & XIX. ker. & 714 & 952 & 75 & 165,1 \\
\hline
\end{tabular}

\footnotetext{
${ }^{39}$ Vastagon dőlten szedetten kiemelve a dolgozatban a későbbiekben részletesen vizsgált projektek szerepelnek.
} 
A Városfejlesztési Kézikönyv hosszan foglalkozik a városfejlesztő társaságok létesítésének kérdésével, mivel a „funkcióbővítő, illetve szociális városrehabilitációra irányuló akcióterületi tervek (ATT-k) megvalósításához professzionális városfejlesztési projektmenedzsment szükséges”. (Városfejlesztés Kézikönyv 2009: 97). Bár a pályázati kiírás nem tartalmazta a városfejlesztési társaság létesítésére való kötelezést, azonban a projekt lebonyolításához a város a rehabilitációért felelő, hosszútávon fenntartható menedzsment szervezet létrehozása kötelező eleme volt a pályázatnak (KMOP 5.5.2/B pályázati kiírás: 14). A pályázati kiírás nyertes pályázatai között, három kiemelt projekt, illetve hét nem kiemelt projekt kapott támogatást.

Jelen dolgozat kerete nem ad lehetőséget, a témája pedig nem indokolja a pályázati kiírás által támogatott összes projekt eredményének részletes áttekintésére. A kutatás témájához igazodva, ezért öt olyan beruházás részletes elemzésére kerül sor, amelyek területén vagy közvetlen vonzáskörzetében átalakuló városi területek találhatók, illetve amelyek ezekre várhatóan hatást gyakorolnak. A fővárosi átalakuló városi területeket két korábbi kutatás alapján vizsgálom. Az egyik az E-build Kft által készített elemzés a fővárosi rozsdaövezeti területekröl (E-build 2007: 56), a másik az Ecorys Kft tanulmánya (Ecorys 2005: 6) Budapest város-rehabilitációs akcióterületeiről.

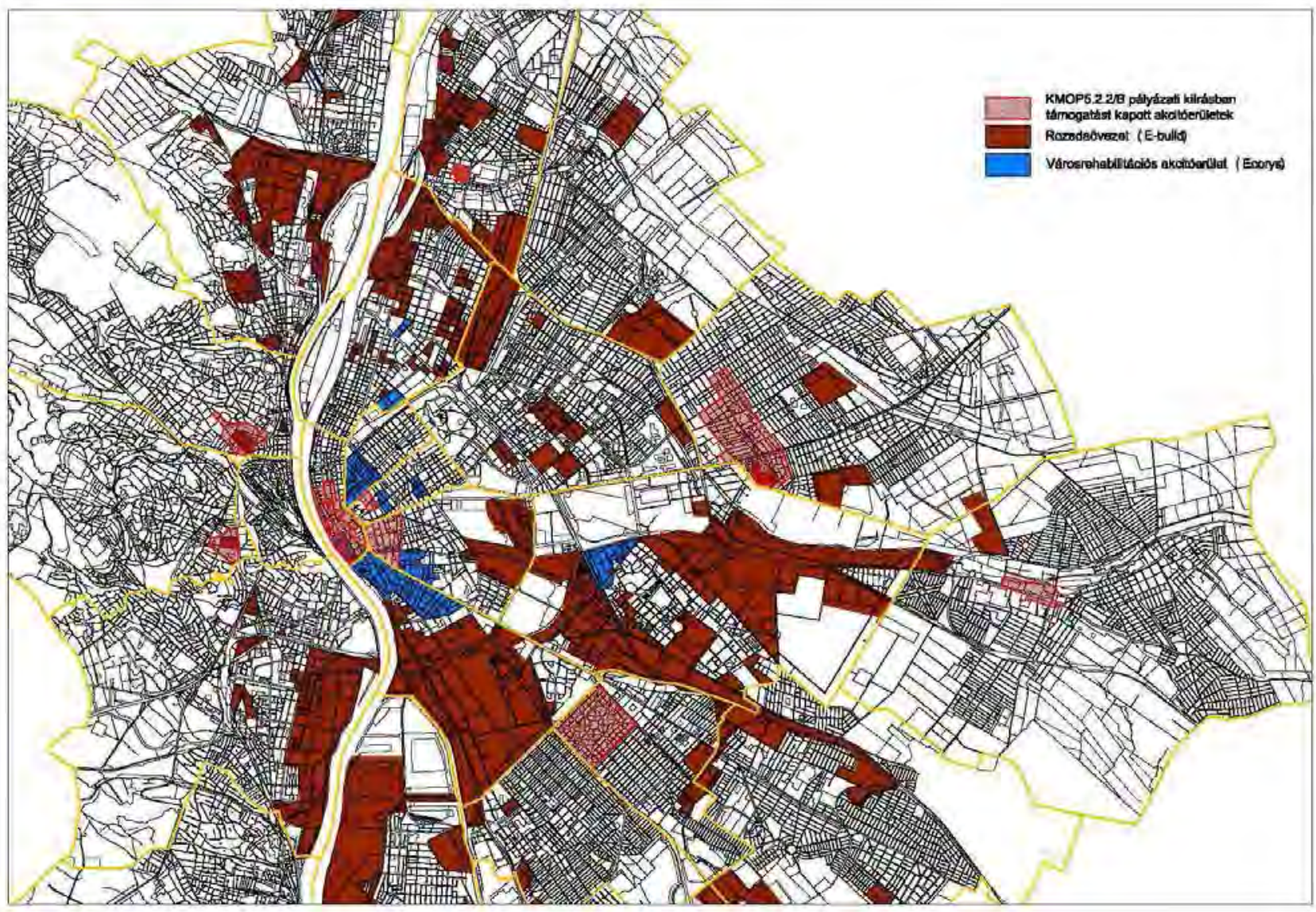

12. ábra: A KMOP 5.5.2 pályázat győztes akcióterületei és a főváros rozsdaövezeti valamint rehabilitációs területek (forrás akcióterületi tervek, Ebuild 2007, Ecorys 2005) 
Vizsgálatunkban az ezen két kutatás által kijelölt rozsdaövezeti és városrehabilitációs akcióterületek együttesét tekintem a budapesti átalakuló városi területeknek.

A fenti szempontok alapján öt olyan projekt szerepel a KMOP 5.5.2/B pályázati kiírásán támogatást nyert projektek között, melyek átalakuló városi területek megújítása kapcsán relevánsak:

1. Budapest Szíve Program - Reprezentatív kaputérség kiépítése, I. ütem

2. Nagyvárosi jövő - Új Főtér, Újpest

3. "Kultúra utcája" Budapest, Erzsébetváros funkcióbővítő rehabilitációja

4. Palotanegyed, Józsefváros

5. Sashalom városközpont komplex városrehabilitációja

A vizsgálat körébe nem kerül be Bel-Buda funkcióbővítő rehabilitációja és a MOM Gesztenyéskert projekt. Mindkét fejlesztési akcióterület ugyan korábbi barnamezős területet érint, azonban ezek rehabilitációja mára már megvalósult (Milenáris park, MOM park). Tehát ezek a beruházások nem alulhasznosított városi területek megújítását célozzák elősegíteni, hanem már rehabilitált területek további fejlesztését célozzák. A Wekerle telep a ferencvárosi és a kőbányai rozsdaövezeti területek szomszédságában található, azonban a területen történt beruházás (Kós Károly park felújítása) léptéke és hatás rendkívül lokális. A Keresztúri beruházás átalakuló területektől elszigetelt környezetben valósul meg. A Budapest Szíve - Hídfőterek, valamint Belváros Főutcája programok pedig a főváros belső magjában lévő, alulhasznosítottnak nem tekinthető területeket érintenek.

\subsubsection{Budapest Szíve Program - Reprezentatív kaputérség kiépítése, I. ütem}

\section{$\underline{\text { Az akcióterület helye az IVS-ben }}$}

A Fővárosi Önkormányzat IVS dokumentumának kidolgozására 2008.végén, a kerületi IVS-ek kidolgozását követően került sor. Ennek eredményeképpen, a fővárosi IVS voltaképpen a kerületi fejlesztési stratégiákban megfogalmazott célokat gyüjtő, azokat rendszerezni próbáló dokumentumként jött létre. A dokumentum maga nem jelöl ki akcióterületeket, hanem hat darab több kerületre kierjedő ún. „,projekttérségeket” határoz meg és azokban fővárosi, illetve kerületi önkormányzatok által megvalósítandó projekteket veszi sorra. 
A Budapest Szíve Program - Reprezentatív kaputérség kiépítése I. ütem projekt ennek következtében nem is a fövárosi, hanem az V. kerületi IVS-re hivatkozik az IVS-hez való igazodás bemutató fejezetében. Ezzel párhuzamosan az V. kerületi IVS által kijelölt akcióterületek túlterjednek a kerület közigazgatási határán, aminek indoka az EU pályázatok lebonyolítását végző illetékes Irányító Hatáság (Nemzeti Fejlesztési Ügynökség) által kért módosítás. Az V. kerületi IVS területen kívüliségének elfogadása érdekében a Fővárosi Önkormányzat tulajdonosi és projektgazda minőségében egyeztetett az érintett szomszédos (VI., VII.) kerületi önkormányzatokkal, megszerezve azok hozzájárulását. (V. IVS: 6) A kerületi IVS hét akcióterületet jelöl ki, melyek több helyen átfednek egymással, illetve két helyen a szomszédos kerületre is kiterjednek. Ezek közé tartozik a „Reprezentatív kaputérségek kiépítése” akcióterülete is. (Lásd 4. számú melléklet.)

Az V. kerület IVS dokumentumában deklarált elsődleges célja „a városrész lakófunkciójának megerösítése, a demográfiai mélyrepülés megállítása, Belváros-Lipótváros magas lakóterületi státuszának helyreállítása, integrálva a Főváros versenyképességi-gazdaság-, azon belül turizmusfejlesztési szándékait.” (V. ker. IVS: 4)

\section{$\underline{\text { Az akcióterületi tervben megfogalmazott célok és elért eredmények }}$}

Az ATT a terület adottságait elemezve az egyik jelentős problémaként a területen lévő 964 lakásban lévő 678 háztartást írja le. Vagyis, hogy a területen lévő lakásállomány vagy üres, vagy nem lakás célú hasznosítás alatt áll. Ez a megállapítás teljes összhangban van az V. kerületi IVS fő célkitüzésével. Ugyanakkor a tanulmány jelzi azt a trendet is, hogy a kerületben a nagy értékü luxuslakások iránt nő az érdeklődés. Ennek az értékelésnek megfelelően a $70 \mathrm{~m}^{2}$ körüli átlagos lakásméretet jó adottságnak tekinti, (ATT: 41) illetve a közösségi beavatkozás következtében várható ingatlanérték növekedést is - a várható értékalapú helyi adó rendszer bevezetését követően

- többlet önkormányzati bevételi forráslehetőségként írja le. (ATT: 68). Kérdés, hogy ezek a dzsentrifikációs irányú beavatkozások valóban a „demográfiai mélyrepülés” megállításának leghatékonyabb eszközei, vagy éppen felerősítik a kedvezőtlen folyamatot.

Az akcióterületi terv a fejlesztés társadalmi céljaként az identitásteremtő, a sokoldalú térhasználatot generáló, nagy közösségi vonzerőt jelentő gyújtópontjának megteremtése egy új reprezentatív városi tércsoport létrehozását, illetve városi rekreációs kínálatának mennyiségi és minőségi fejlesztését jelöli meg. Gazdasági célok között a terület tőkevonzó képességének növelése illetve a kiskereskedelem „plázákkal szembeni” versenyképességének növelése jelenik meg. A környezeti 
célok között a városépítészeti értékek érvényesülésének segítése, valamint a közlekedésből eredő terhelések csökkentése szerepel.

16. táblázat: Budapest Szíve - Reprezentatív kaputérség ATT: a projekt keretében megvalósuló fejlesztések (ATT: 3-5)

\begin{tabular}{|c|c|}
\hline Projekt elem & $\begin{array}{l}\text { Összes költség } \\
\text { mill. Ft (nettó) }\end{array}$ \\
\hline Budapest, V. ker. Sütő u. 2. sz. alatti Tourinform iroda fejlesztése & 30,8 \\
\hline $\begin{array}{l}\text { Astoria kereszteződés forgalomtechnikai átalakítása - közlekedésbiztonság } \\
\text { javítása }\end{array}$ & 245,8 \\
\hline $\begin{array}{l}\text { Károly körút Astoria és Dohány utca közötti szakaszán gyalogosfelületek } \\
\text { szabadtér-építészeti felértékelése }\end{array}$ & 334,6 \\
\hline $\begin{array}{l}\text { Reprezentatív bulvár kialakítása a Károly körút Dohány utca és Deák Ferenc tér } \\
\text { közötti szakaszán }\end{array}$ & 2501,7 \\
\hline $\begin{array}{l}\text { Az infrastrukturális, beruházás jellegü fejlesztéseket kiegészítő kisléptékü } \\
\text { ("soft") elemek keretében } \\
\text { A Károly körút falfirka-mentesítése társadalmi akció keretében } \\
\text { Identitásteremtés és közösségépítés a Belvárosban } \\
\text { Parkosításhoz kapcsolódó lakossági akciók a projekt megvalósítás időszakában }\end{array}$ & 25,7 \\
\hline Összesen & 3138,8 \\
\hline
\end{tabular}

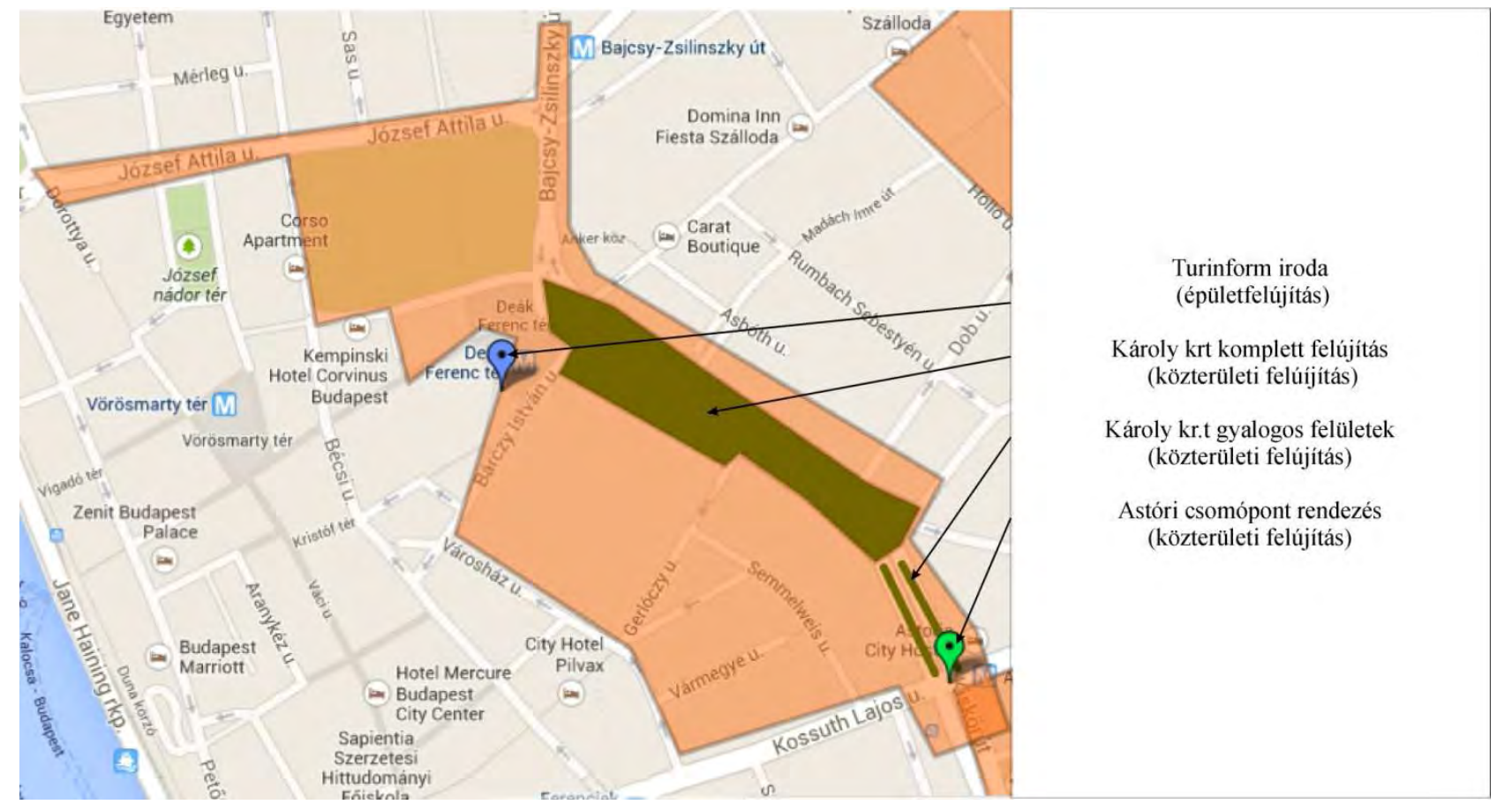

13. ábra: Budapest szíve, kaputérség beruházás keretében megvalósuló épített projektelemek.

A dokumentum számba veszi az akcióterülethez kapcsolódó, a közszféra által megvalósítandó egyéb beruházásokat. Ennek keretében említik meg a társasházak megújításának fővárosi támogatását, a passzázsok közcélra való megnyitását, az alulhasznosított ingatlanok fejlesztését, a 47-49-es villamos továbbvezetését. Ezeknek az akcióterülethez kapcsolódó fejlesztéseknek a 
részletesebb bemutatását nem tekinti a dokumentum feladatának. Ugyancsak a kapcsolódó projektek között szerepel a dokumentum készítésekor még PPP konstrukcióban megvalósítani tervezett Városháza Fórum beruházás. Értékes javaslata a dokumentumnak az egységes (fővárosi és V. kerület) közterület-menedzsment rendszer kialakítása (ATT: 61)

A dokumentum a beruházás indokoltságának kapcsán azt emeli ki, hogy a projekt kapcsán a belváros turisztikai vonzereje, a kiskereskedelem versenyképessége nő, a város egészének javul az élhetősége. A közvetett hatások között az élhető belváros megteremtése révén az agglomerációra nehezedő szuburbanizációs nyomás csökkenését remélik a készítők, illetve a beruházás lebonyolítása eredményeképpen „hatalmas tudás és tapasztalat halmozódik fel komplex, nagyléptékü programok, projektek lebonyolításában”.

A kvalitatív interjúkban elhangzottak szerint a kivitelezési munkálatok 2010 júniusában kezdődtek meg és 2011 szeptemberében befejeződtek, mely során valamennyi pályázati elem megvalósult. A Budapest Szíve Városfejlesztő Nonprofit Kft. (BSz) munkatársai szerint a beruházás révén a területen zöldfelületi növekedést, gyalogos és kerékpáros területek minőségi és mennyiségi növelését, közterületi arculatváltást értek el. A lebonyolító szervezet a projekt fontos részének és eredményének tekinti a megvalósult, ún. „szoft” projektelemeket; graffiti-mentesítési kampány, társasházi fórumok rendezése, a hatékony társasházkezelés példáinak ismertetésére, üzletutca program a helyi üzlettulajdonosok részére az online marketingről, közterületi kulturális rendezvények megteremtése. A beruházás keretén belül ezzel a fejlesztés társadalmi elfogadását, a helyi identitás erősítését, a terület arculatának, vonzerejének javítását tüzték célul. Eredménynek tekintik a lebonyolítók, a projekt megvalósulását követően létrejött megújuló üzlethelységeket is. Az akcióterületi tervben kapcsolódó beruházásként jelzett Városháza Fórum és mélygarázs építési beruházás teljesen leállt.

\section{A projekt megvalósításának szervezeti kerete}

Az ATT 7. fejezete rögzíti, hogy a főváros 100\%-os önkormányzati tulajdonban lévő társaságot hoz létre a beruházás megvalósítására a Fővárosi Közgyülés 2008. novemberi ülésén. Ez a „Városfejlesztő Társaság” az egyes feladatok ellátására külön szerződéseket köt az önkormányzattal. A társaság hatékonyabb, rugalmasabb, átláthatóbb, piacibb szemléletű menedzsmentet biztosít, mint az önkormányzati szervezet keretében való projekt lebonyolítás. A társaság azonban nem teljes mértékben gazdálkodna önállóan, hiszen ,,az önkormányzattól kapott megbízásokat „... önkormányzat számlájára hajtja végre, így az akció nyereségelvesztesége az 
önkormányzatot illeti.” (ATT: 148) Mivel a Budapest Szíve Program két fővárosi és egy kerületi projektje szervesen összefügg, ezért egy-egy Projekt Irányító Bizottság (PIB) létrehozására tesz javaslatot a dokumentum, mely a koordinációs feladatokat ellátja. A projekt integrált irányítására, stratégiai, döntéshozói funkciójának megvalósítására egy Irányító Testület (Projekt Irányító Bizottság - PIB) kerül delegálásra. A PIB felel a stratégiáért és biztosítja a szükséges intézményi hátteret. A PIB irányítja az egyes projektek megvalósításáért felelős operatív egységeket, amely projektenként különbözőek.

A projekt megvalósításáról adott interjúban a Tóth Sándor a BSz kommunikációs igazgatója és munkatársai vázolták a megvalósítás szervezeti keretét. Tájékoztatásuk szerint EU-s elvárások miatt alapította önálló nonprofit cég formájában a főváros a társaságukat, melynek a tulajdona később átkerült a szintén fővárosi tulajdonban lévő Budapesti Közlekedési Központhoz. A társaság koordinálásában megvalósuló projektek lebonyolítására közszolgáltatási szerződés született. A tulajdonosi döntést igénylő kérdésekben a fővárosi közgyülés kompetens a döntéshozatalban, azonban az egyéb kérdésekben a projekt kapcsán felállított Projekt Irányító Bizottság (PIB) a stratégiai döntéshozó. A PIB a fővárosi és az V. kerületi önkormányzat által közösen felügyelt, társelnökség alatt működtetett szervezet, mely a két önkormányzati közötti kommunikációt és együttmüködést hivatott javítani. Munkáját a Budapest Főváros Főpolgármesteri Hivatal (BFFH) Projektmenedzsment Főosztálya koordinálta, az üléseket a főosztály készítette elő. A PIB ülésein a BSz rendszeres beszámolókat tartott a projekt előrehaladásáról.

A BSz létrehozásával az önkormányzattól elkülönült, annál gyorsabb reagálású szervezet felállítása volt a cél a tervezési és a kivitelezési feladatok koordinálására. A szervezet feladata a projekt adminisztrációjának lebonyolítása. A cégvezetés véleménye szerint a BFFH kereteiben müködő szervezeti egység nem képes komplex feladatok kapcsán képviselni az önkormányzat érdekeit. A BSz azonban folyamatos kapcsolatot tartott fenn a BFFH érintett osztályaival; a Projekt Menedzsment Főosztállyal, Városüzemeltetési Főosztállyal.

A projektet felügyelő Közremüködő Szervezet a Pro Régió Közép-Magyarországi Regionális Fejlesztési és Szolgáltató Nonprofit Kft. (Pro Régió) volt. A kapcsolattartást kezdetben a Projekt Menedzsment Főosztály végezte, és ők közvetítettek a BSz irányába az információkat. A megvalósítás későbbi szakaszában, a kommunikáció gyorsítása érdekében egyre több kérdésben BSz és a Pro Régió közötti informális kapcsolatok kerületek előtérbe. 


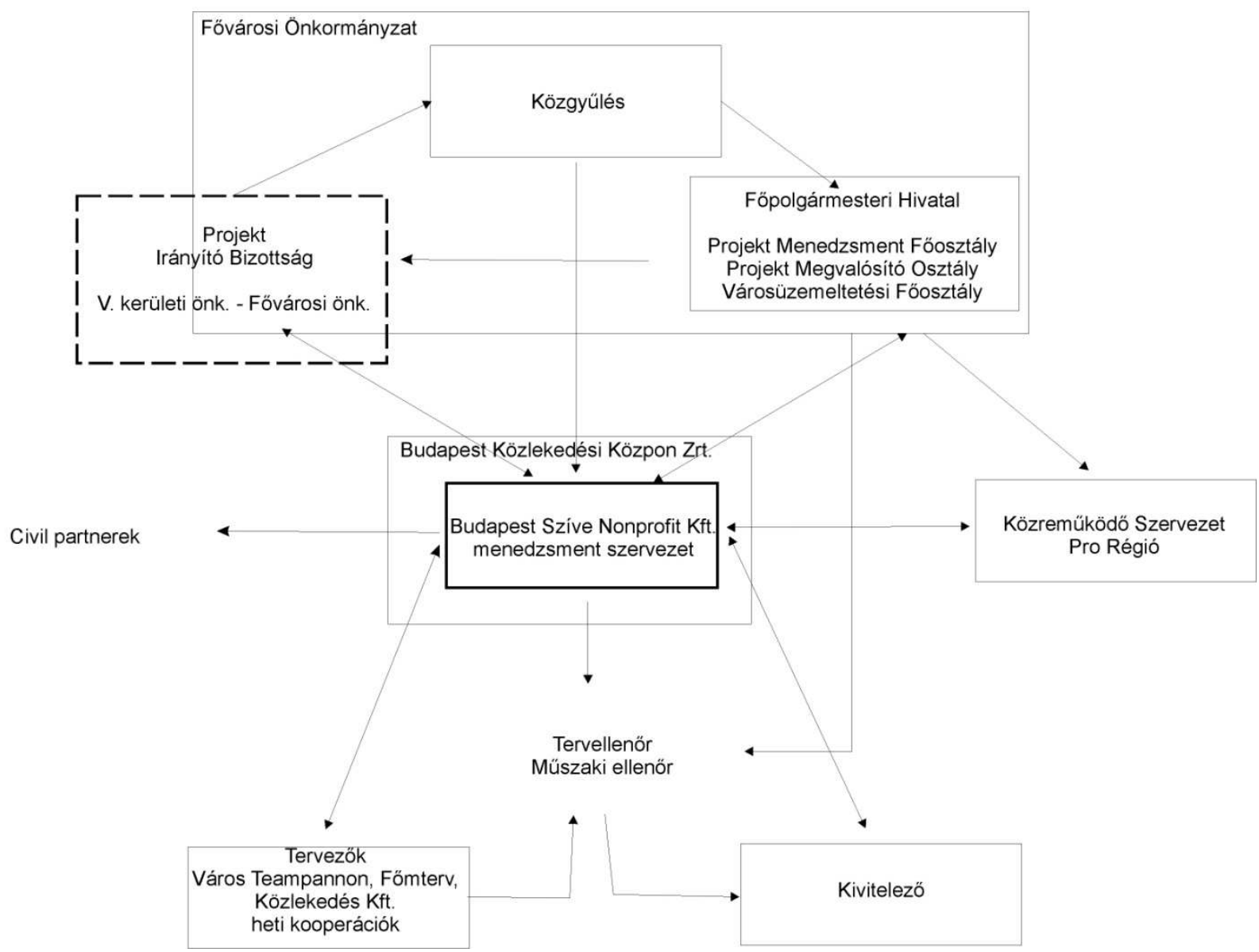

14. ábra: Budapest Szíve Program - Reprezentatív kaputérség kiépítése 1. ütem beruházás megvalósításának szervezeti sémája

A BSz szervezte a rendszeres kooperációs egyeztetéseket a generál tervező irodákkal, illetve esetenként a szakági tervezőkkel is. A generál tervező által leadott terveket tervellenőri vizsgálat után adták át a közbeszerzésen kiválasztott kivitelezőnek. A projekt lezárultát követően a BSz végzi a terület fenntartását a pályázatban elöírt öt éves fenntartási időszakban. További feladatai a cégnek, hogy a BKK által előkészített fejlesztési projektek megvalósítása során a beruházás-bonyolítói feladatokat ellássa.

\subsubsection{Budapest IV. kerület: Nagyvárosi jövő - Új Fötér}

\section{Az akcióterület helye az IVS-ben}

Az Újpesti IVS négy középtávú akcióterületet és 14 távlati akcióterületet jelöl ki a kerület közigazgatási területén. (Lásd 4. számú melléklet.) A Szt. István tér fejlesztése a „Fötér fejlesztése” néven a középtávú fejlesztési célterületek között szerepel. A stratégai részcélja között a „Szent 
István tér és a csatlakozó térfalak rekonstrukciója” illetve a „Szent István térnek a környezö városrészekbe történö gyalogosforgalmi integrációja” egyaránt megjelenik.

\section{Az akcióterületi tervben megfogalmazott célok és eredmények}

A területre 2008-ban készített akcióterületi terv (ATT) rendkívül részletes elemzés alá veti az újpesti lakáspiaci négyzetméterárakat, lakáskínálatot, melyet a fővárosi kínálattal összevetve megállapítja, hogy „Újpest a használt társasházi ingatlanok árai tekintetében utolsó előtti helyen áll” a fővárosban (ATT: 41). A kerületen belüli ingatlanárak vizsgálat során a tanulmány arra a megállapításra jut, hogy Újpest központ és Káposztásmegyer ingatlanárai a legalacsonyabbak, míg a köztes kertvárosias terület ingatlanai ennél jóval értékesebbek. Ebből a dokumentum arra a következtetésre jut, hogy „azok a negyedek a legértékesebbek, ahol van elegendö és minöségileg is rendezett zöldterület”, ${ }^{40}$ amelyböl következik a központi tér, a Szent István tér, mint fötér komplex megújításának szükségessége:

„A Szent István tér rehabilitációja közvetlen befolyással van a városközpont lakáspiaci helyzetére. A vonzó térkialakitás, az igazi agora-funkció, a sétálóutcák valamint a parkolási lehetőségek minimalizálása elösegithetik a terület felértékelödését, az ingatlanárak emelkedését. Ez alapvetö igény Újpest részéröl, mivel egy kerület igazi, értékes központ nélkül nem képes integráló funkciót betölteni." (ATT: 45)

A következtetést nem támasztja alá az ingatlanárakat befolyásoló egyéb tényezők (lokáció, közlekedési kapcsolatok, intézményi ellátottság, beépítési és épületminőségi paraméterek) vizsgálata, így a következtetés bizonyítottsága megkérdőjelezhető. A dokumentum azonban nyilván nem tudományos igénnyel, hanem pályázati célból készült, mely funkcióját, az eredmények ismeretében, megfelelően betöltötte. A kerületrész ingatlanpiaci pozíció javításán túlmenően azonban a tanulmány a fejlesztés társadalmi, gazdaságfejlesztő, illetve környezeti jelentőségét is bemutatja. Ez utóbbi kapcsán a készítők állítása szerint a ,zöldterület fejlesztés önmagán túlmutató rehabilitációs tevékenység”, melynek továbbgyürüző hatása számos egyéb területen is jelentkeznek. (ATT: 50). Az akcióterületi beavatkozásnak ennek megfelelően hármas célja van: gazdaságélénkítés, társadalmi kohézió erősítése és a városi környezet minőségének javítása. Az akcióterületi fejlesztések három ütemben megvalósuló sorozatával a közszféra (önkormányzat, állam, EU) 3,35 mrd. Ft-os beruházása (közterületek megújítása, piac felújítása) cca. 11,5 mrd. Ftos magánberuházást vonzhat a térségbe (mélygarázsépítés, környezö épületek megújítása). A

40 
dokumentum becslést végez a beruházás által remélhetö önkormányzati haszonra is, melyet a területen lévő üzletek többlet bérleti díjának növekedéséből származik, és elérheti a 20-30\%-os többletet. A dokumentum kiemeli, hogy a tér körüli kiskereskedelem a beruházás révén versenyképessé válhat a bevásárlóközpontokkal. (ATT: 56). Az akcióterületi fejlesztés I. ütemében megvalósítani tervezett beavatkozások:

17. táblázat: Újpest Főtér ATT: a projekt elszámolható költségei(ATT: 138) - Építési költségek

\begin{tabular}{|l|r|}
\hline \multicolumn{1}{|c|}{ Projekt elem } & $\begin{array}{r}\text { Összes költség } \\
\text { mill. Ft (nettó) }\end{array}$ \\
\hline Szent István tér 23.-Mády Lajos utca 2. homlokzatának részleges felújítása & 5,833 \\
\hline István út 12. sz. épület homlokzatának részleges felújítása & 7,083 \\
\hline Rathauskeller kialakítása (830m2) & 55,167 \\
\hline Üzletutca program & 8,333 \\
\hline Szent István tér közterület rehabilitáció (15969m2) & 566,667 \\
\hline Mády Lajos utca közterület rehabilitációja (965m2) & 33,333 \\
\hline Városháza korszerüsítése (fútéskorszerúsítés, nyílászáró-csere, belső udvar) & 266,667 \\
\hline Egyéb (egyéb gazdaságfejlesztési és járulékos költségek) & 256,667 \\
\hline Összesen & $\mathbf{1 ~ 1 9 9 , 7 5 0}$ \\
\hline
\end{tabular}

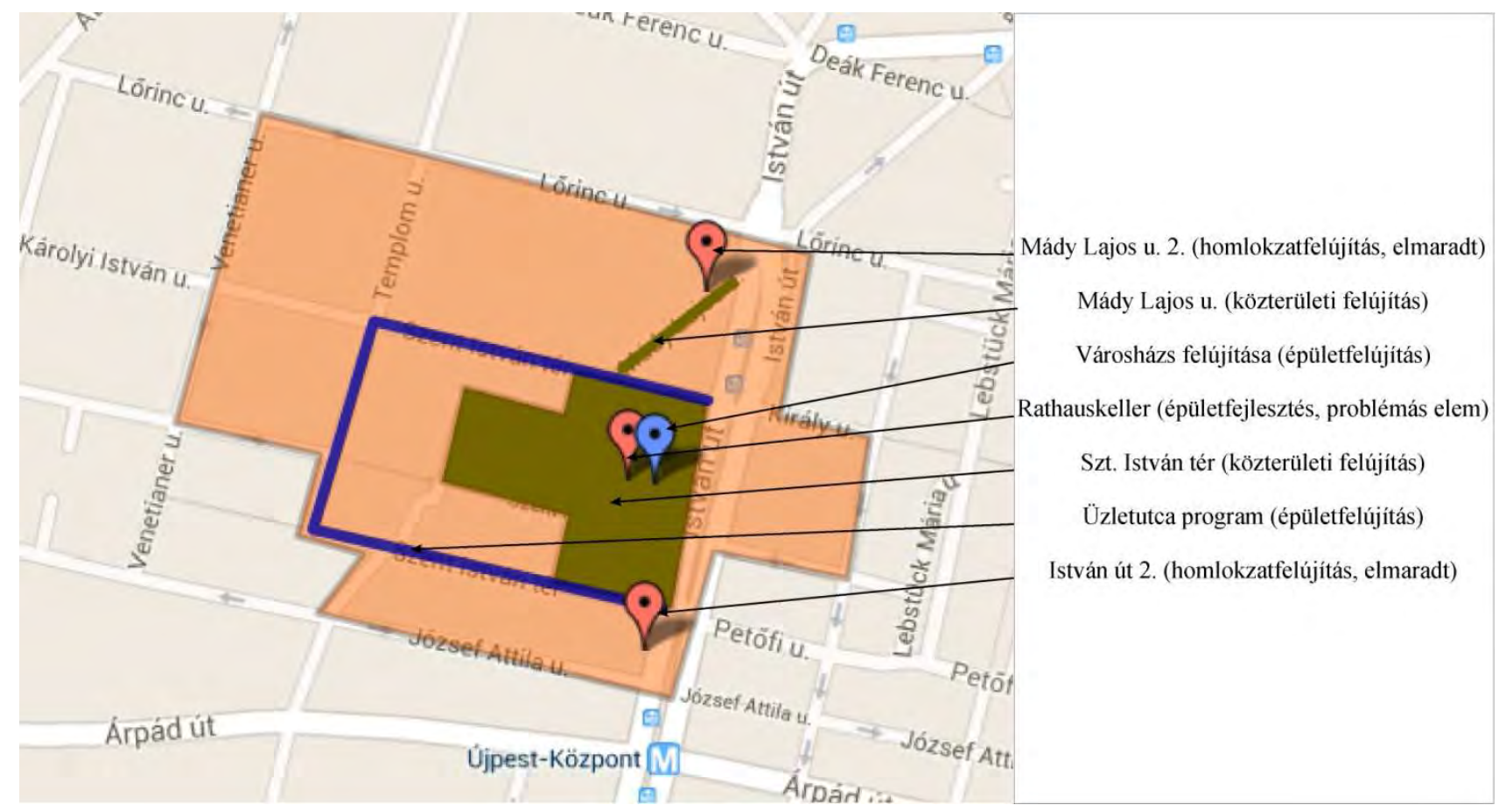

15. ábra: Újpest új főtér beruházás keretében megvalósuló épített projektelemek.

A projekt megvalósítása során azonban az ATT-ben szereplő célkitűzésekhez képes jelentős visszalépések történtek. A tulajdonosokkal való megegyezés elmaradása miatt nem került sor sem a Mády Lajos utca 2, sem az István út 12. számú épület homlokzatának felújítására. A Rathauskeller kialakítása megtörtént ugyan, azonban mind a mai napig nem talált bérlőre a városháza 
pinceszintjében lévő vendéglátási célú helyiség. Ennek oka leginkább a megvalósítás müszaki minősége. A projekt kivitelezése során tervpályázat került kiírásra a főtér felújításának ATT szerinti második ütemére mélygarázs és világpiac megépítésére. A sikeres pályázatot azonban nem követte megvalósítás, az önkormányzat végül elvetette a mélygarázsépítés ötletét, szükségtelennek és finanszírozhatatlannak ítélve azt.

\section{A projekt megvalósításának szervezeti kerete}

Az ATT szerint a Városüzemeltetési Iroda keretében müködő ideiglenes projektmenedzsment helyett, a városfejlesztő társaságban müködő „,stratégai menedzsment” szervezet látja el az IVS menedzselését. Ehhez kapcsolódnak majd az egyes egyedi projektek lebonyolítását vezénylő projektmenedzsment szervezetek. A szervezeti ábra ügyel rá, hogy a meglévő szervezetek és önkormányzati társaságok a tervezett átalakulást követően is szerepeljenek a résztvevők között, vagyis a városfejlesztő társaság létrejötte nem eredményezi a tervek szerint az önkormányzat szervezeti egységeinek illetve cégeinek változását. A dokumentum jelzi, hogy a Nemzeti Fejlesztési Ügynökség (NFÜ) elvárásainak megfelelően 100\%-os önkormányzati tulajdonú Kft formájában alakul meg a társaság 500000 Ft törzstőkével. A készítők elképzelése szerint „a Társaság - $a$ tulajdonába kerülö vagyonelemek bevételeit, valamint azon vagyonelemek bevételeit, melyek vonatkozásában ezt önkormányzat z számára biztosítja, visszaforgatja városfejlesztési célra. A projekt során szerzett tapasztalatok, valamint az egyes akcióterületi fejlesztések konkrét tartalma függvényében az önkormányzat akcióterületenként vagy projektenként szerzödik a társasággal az akcióterületi fejlesztések vagy egyes projektek (részprojektek) megvalósítására.” (ATT: 128) Ezt követően a társág az Önkormányzat nevében eljárva hajtja végre a stratégiai dokumentumokban megfogalmazott városfejlesztési feladatokat.

A projekt megvalósulásának szervezeti kereteiről Berényi András főépítész és Nagy Elemér a Városüzemeltetési Főosztály főmérnöke adott interjút. A projekt megvalósításának központi, a tervezéstől a megvalósításig müködő, döntéshozó fórumát a gazdasági ügyekért felelős alpolgármester heti rendszerességü kooperációs megbeszélései jelentették, azonban a hivatalos határozatokat természetesen itt is a képviselő testület hozta meg. A pályázat készítését és az engedélyezési tervek koordinálását a Városüzemeltetési Főosztály koordinálta, a Főépítészi Iroda véleményezte a terveket. Az Újpesti Vagyonkezelő Zrt részt vett az egyeztetéseken, azonban feladata a fejlesztési témakörökre nem terjedt ki. 
A pályázati elvárások figyelembe vételével került sor a projekt kivitelezését koordináló Újpesti Főtér Városfejlesztési és Beruházó Kft. (Főtér Kft.) megalakítására, mely háromfős cégként müködve a kivitelezési munkák felügyeletét és koordinálását, valamint a Közremüködő Szervezettel való kapcsolattartás feladatait látta el. A kivitelezési feladatokat az önkormányzat által kiírt közbeszerzésen kiválasztott kivitelező konzorcium végezte. A kivitelezés során a heti rendszerességü alpolgármesteri kooperációkon felül a Fötér Kft. telephelyén folyamatosan zajlottak a kivitelezéssel kapcsolatos, részleteket érintő egyeztetések. Ebben a Főépítészeti Iroda is részt vett alkalmanként.

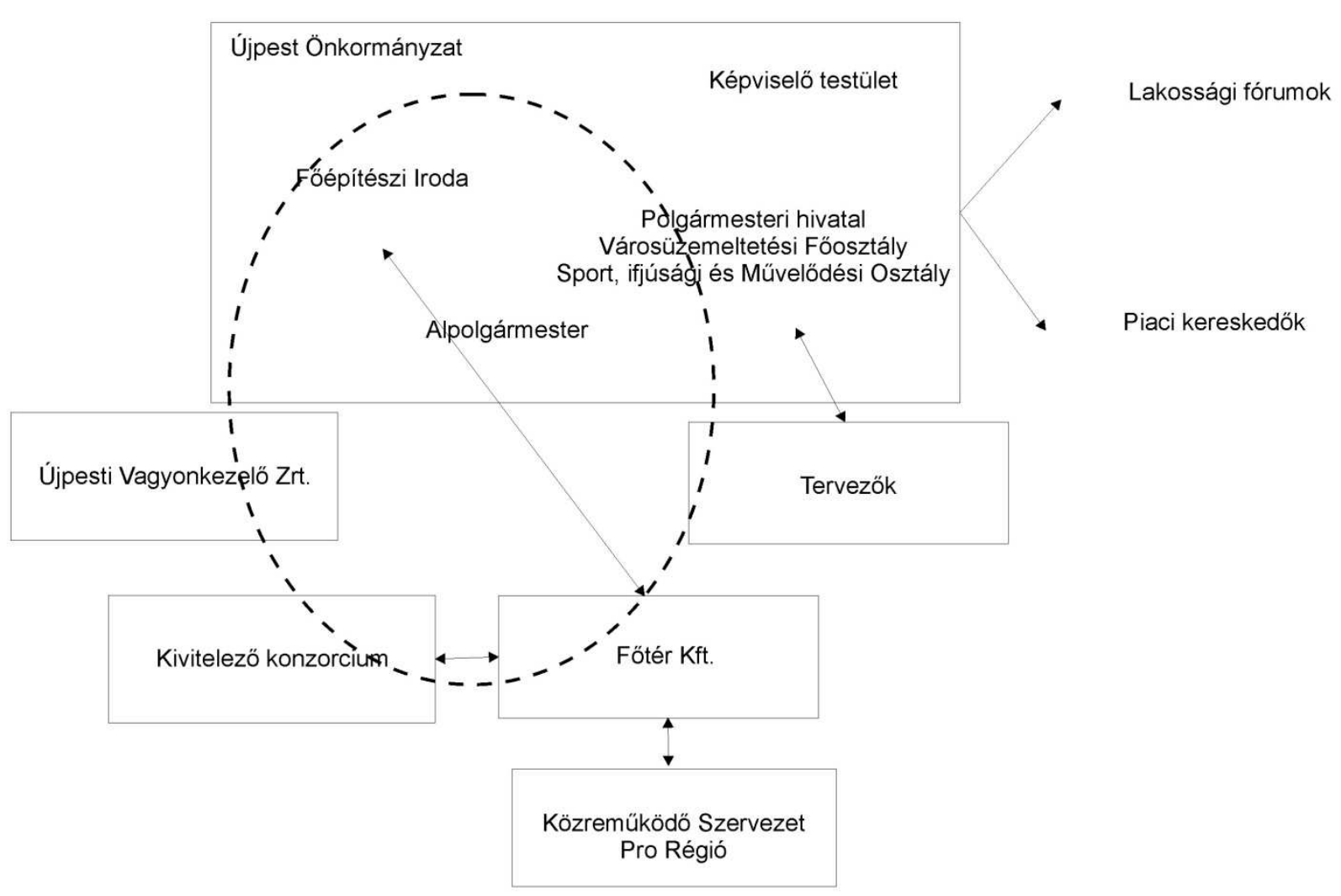

16. ábra: Újpest Új Főtér beruházás megvalósításának szervezeti sémája

A lakossági egyeztetések a projektet bemutató lakossági fórumokon történő projektismertetésekre, illetve a piaci kereskedőkkel való egyeztetésekre korlátozódtak. A piaci kereskedők jelentős érdeksérelemnek tekintették, hogy a köztér forgalommentesítése kapcsán korábbihoz képest parkolási lehetőségeik korlátozottabbak lettek. A velük való egyeztetések kompromisszumaként egy kisebb, díjmentes kereskedői parkolóterület kijelölése lett. A projekt legnagyobb eredménye a riportalanyok véleménye szerint, a fötér forgalommentes közösségi térré alakítása volt. Fontos eredménye volt a beruházásnak a riportalanyok véleménye szerint, hogy reprezentatív városi teret 
hozott létre az azóta rendszeresen - az polgármesteri hivatal Sport, Ifjúsági és Mủvelődési Osztálya szervezésében - megrendezésre kerülő közösségi rendezvények számára.

A Főtér Kft a projekt megvalósítását követően miután egyértelművé vált, hogy nem folytatódik a projekt a tervezett második ütemmel, megszűnt és jogutódja az 2011 februárjában alapított Újpesti Városgondnokság Kft lett. A cég az új fötér üzemeltetésén túl a kerületi parkok, játszóterek és zöldfelületek fenntartását végzi valamint ingatlangazdálkodási feladatokat is ellát.

\subsection{3. "Kultúra utcája" Budapest, Erzsébetváros funkcióbővítö rehabilitációja}

\section{$\underline{\text { Az akcióterület helye az IVS-ben }}$}

Erzsébetváros IVS-e a B1 jelü akcióterületeként (lásd 4. számú melléklet) meghatározott „Kultúra utcája” akcióterületi területének kijelölésének indoka: „hogy szervesen kapcsolódik a jelenleg folyamatban lévő - elsősorban vállalkozói alapon megvalósuló - beruházásokhoz (Madách-sétány, Gozsdu-udvar, stb.). Az önkormányzati akció határozott célja, hogy az elsősorban piaci igényeket kielégítö magánberuházásokat (lakásépítés, irodaépítés) összekapcsolja a terület kulturális felértékelésével, összhangban a „régi pesti zsidónegyed” felélesztésének koncepciójával. Ennek részeként kívánja megvalósítani az Önkormányzat a „Kultúra utcáját” a Kazinczy utca egy szakaszán.” (IVS: 13)

\section{$\underline{\text { Az akcióterületi tervben megfogalmazott célok és eredmények }}$}

A dokumentum az akóterületen meghatározónak jelzi a kereskedelem, vendéglátás intézményeinek, valamint a közigazgatás és a közösségi intézmények jelenlétét. Ugyanakkor hiányként tünteti fel az ipar, illetve az adózás szempontjából meghatározó vállalkozások székhelyeit (ATT: 21). A terület társadalmi összetételének szempontjából az alacsony státuszú, alacsony iskolai végzettségű népesség jelentős súlyát, illetve a „munkaerőpiacról társadalmilag nem indokolható módon távol maradók” magas arányát jelzi problémaként az ATT (ATT: 27). A területen lévő lakásállomány korszerütlensége, a zöldfelületek hiánya, illetve a közlekedési felületek túlzsúfoltsága jelenti a fizikai környezet legföbb hiányosságait. (ATT: 30). Az akcióterületen magas a részben vagy egészben önkormányzati tulajdonban lévő ingatlanok száma. 
Az ATT részletesen tárgyalja területen lévő tömbök tulajdoni viszonyait, a felújítási, bontási feladatokat, a javasolt beépítési paramétereket. Az akcióterület fejlesztésének fő célja: „a terület arculatának, identitásának megörzése, a területen lakók életminöségének javitása, a terület turisztikai vonzerejének növelése, a Kultúra utcájának megvalósítása.” (ATT: 43)

A részletes célok között a közterületek felújítása, a komfort nélküli lakások felszámolása, a tömb rehabilitáció kiemelten jelenik meg. Társadalmi, gazdasági célként pedig a „terïleten kialakult alternatív kulturális törekvések” támogatása és a „hagyományos zsidó kultúrához, életmódhoz kapcsolódó kézmüipari és egyéb tevékenységek” fejlesztése szerepel. (ATT: 44). A terület lakóépületeinek felújítás során 109 alacsony komfortfokozatú lakás bontására kerül sor a tervek szerint, a tömbbelsőkben rendezett közterületek kialakításával. A bontásra kerülő lakások lakói kisebb részben az adott tömbben történő ráépítések során létesülö lakásokba, nagyobb részben egyéb - akár más városrészben megvásárlásra kerülö - lakásokba való költözéssel jutnának új otthonokhoz. Az IVS antiszegregációs terve azonban jelzi, hogy a rehabilitáció következtében a területről elköltözőknek elsősorban a kerületen belül próbál az önkormányzat lakást biztosítani. (IVS: 137) A dokumentum az egyes kiköltöztetésre kerülő családoknak több alternatívából való választás lehetőségét javasolja középső Ferencvárosi tömbrehabilitációs példára hivatkozva. ${ }^{41} \mathrm{~A}$ projekt közterületi elemei a Kazinczy, Síp és Dob utcák érintett szakaszainak forgalomcsillapítása, a tömbbelsőkben közterület kialakítása. A fejlesztések részletes, költségeket is tartalmazó bemutatása, már csak az KMOP pályázati projekt keretében megvalósítandó fejlesztéseket tartalmazza.

18. táblázat: Kultúra utcája ATT: a projekt keretében megvalósuló fejlesztések (ATT: 96)

\begin{tabular}{|l|c|}
\hline \multicolumn{1}{|c|}{ Projekt elem } & $\begin{array}{c}\text { Összes költség } \\
\text { mill. Ft (bruttó) }\end{array}$ \\
\hline Dob u. 29 múemléki épület homlokzat felújítás & 78,41 \\
\hline Környezettudatos magatartásra nevelö központ & 48,6 \\
\hline Zsidó negyed I pont (információs pont) létesítése, Kazinczy u. 34 & 31,27 \\
\hline Kazinczy u. 34 védett épülethomlokzat felújítása & 100,00 \\
\hline Kávézó étterem és shop, Kazinczy u. 34. & 36,47 \\
\hline Zsinagóga felújítása & 110,50 \\
\hline $\begin{array}{l}\text { ELTE Pedagógiai és Pszichológiai Kar aulája átépítése, konferenciaterem } \\
\text { kialakítása }\end{array}$ & 96,00 \\
\hline Elektrotechnikai Múzeum épület felújítás & 97,00 \\
\hline Elektrotechnikai Múzeum hátsó épület felújítás & 131,833 \\
\hline
\end{tabular}

${ }^{41}$ Nem véletlen a Ferencvárosi tömbrehabilitációra való hivatkozás. A dokumentumot készítő Városkutatás Zrt (korábban SCET Magyarország Városfejlesztő Rt) készítette 2002-ben a középső Ferencváros rehabilitációs terület szabályozási tervét. Igazgatóságának elnöke, Aczél Gábor a ferencvárosi tömbrehabilitációt korábban koordináló SEM IX. vezérigazgatója volt. 


\begin{tabular}{|l|c|}
\hline Kazinczy u. felújítása (Dob u. - Wesselényi u. között) & 91,400 \\
\hline Beruházás összesen & $\mathbf{8 2 1 , 4 9}$ \\
\hline Promóció városmarketing, projektmenedzsment) & 29,50 \\
\hline Projekt menedzsment & 50,00 \\
\hline Projekt előkészítés & 103,62 \\
\hline Mindösszesen & $\mathbf{1 0 1 3 , 8 1}$ \\
\hline
\end{tabular}

Az ATT az akcióterület komplex megújítására vonatkozó pénzügyi tervet tartalmazza. Ebben a rehabilitációs tevékenységek (területszerzés, terület-előkészítés, épület-felújítás, lakáspótlás, közterület-fejlesztés, közműfejlesztés) összességének nagyságát 5 mrd. Ft-ra becsüli a dokumentum. A felújítás költségét, jelentős mértékben csökkentheti, a területen lévő ingatlanok eladásával a készítők szerint az önkormányzat forrásigénye közel 50\%-kal mérsékelhető lehet. (ATT: 108) A dokumentum az akcióterületi fejlesztés multiplikátor hatását jelzi elöre, korábbi városrehabilitációs tevékenységek tapasztalataira hivatkozva. A multiplikátorhatás további befektetések, szolgáltatások, munkahelyek területre vonzásában jelentkezik majd. Ezek a hatások számszerüsítésére azonban nem kerül sor a dokumentumban. (ATT: 126)

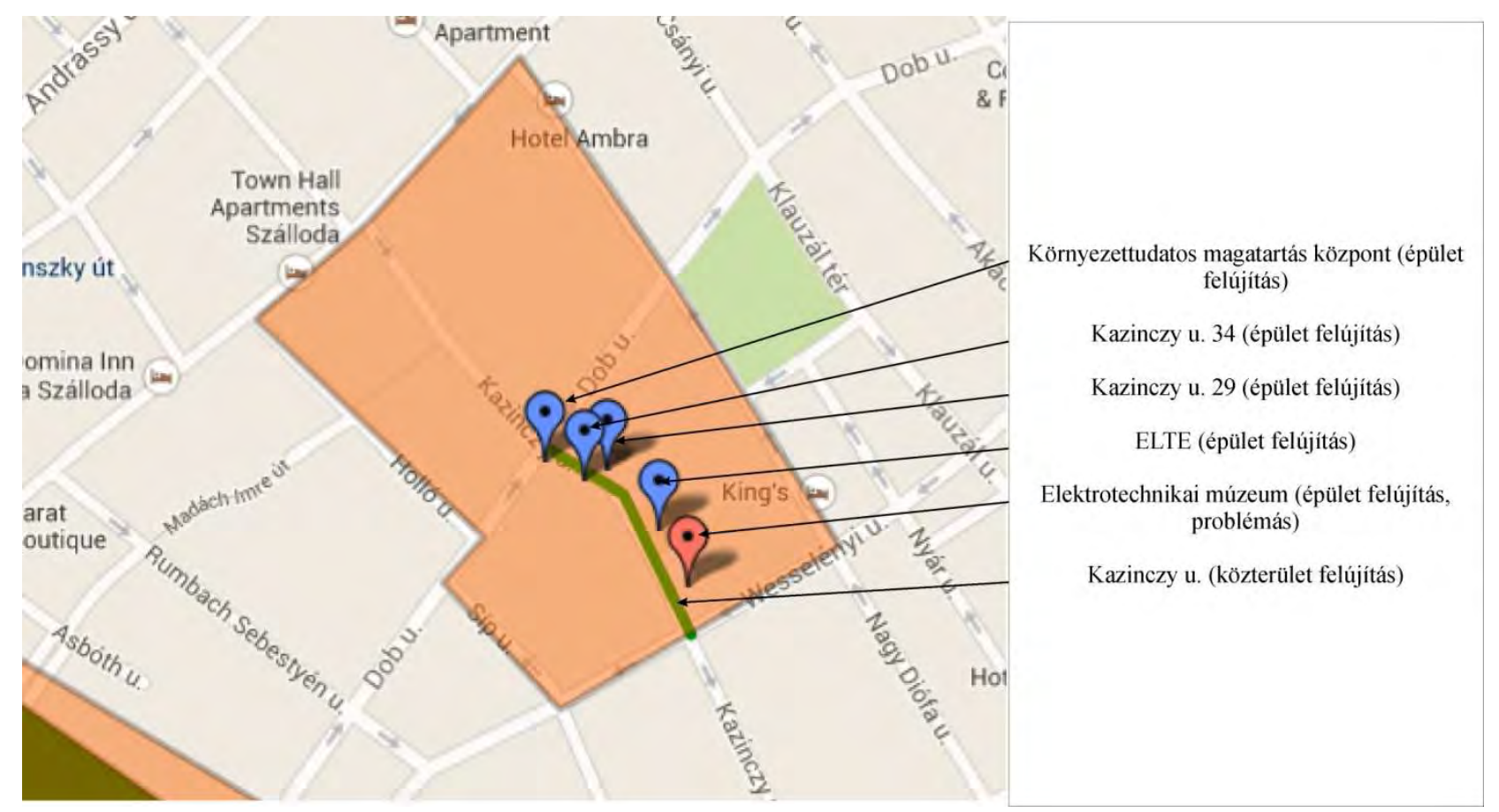

17. ábra: Erzsébetváros Kultúra utcája beruházás keretében megvalósuló épített projektelemek.

A projekt kivitelezése 2010 áprilisában indult, és 2011 végére befejeződtek az építési munkák. A pályázati támogatás elnyerésével együtt azonban egy jelentős problémával kellett szembenézni az önkormányzatnak. A támogatás összege alacsonyabb volt, mint az igényelt támogatás. Füle Gábor interjúja alapján kiderült, hogy döntéshozók annak érdekében, hogy minél több önkormányzatot támogassanak, fünyíró elv szerüen kevesebb támogatást adtak a projektek számára. Tájékoztatása 
szerint ez a korábbi PHARE finanszírozású projekteknél nem volt gyakorlat. Erzsébetváros önkormányzata ezt követően döntéshelyzetbe került: vagy csökkenti a projekt tartalmát, vagy külső forrásokat keres az eredeti tartalom megvalósítására. A támogatás elnyerésekor meglévő piaci konjunktúra, és a közremüködő szervezet biztatása hatására az utóbbi, kockázatosabb megoldást választotta az önkormányzat, magánberuházót keresve az elektrotechnikai múzeum hátsó épületének belső felújítására, majd piaci (vendéglátási célú) hasznosítására. Az ingatlanpiaci recessziót követően azonban a beruházó kihátrált a megállapodásból, és az önkormányzatnak magának kellett 100 milliós többletforrást biztosítani a projekt befejezéséhez. Ennél sikeresebb volt a piaci szereplőkkel való együttmüködés a Kazinczy u. 34. felújítása kapcsán. Itt a felújított épületben sikerült vendéglátási funkciót létrehozni (Kazimir vendéglö).

\section{A projekt megvalósításának szervezeti kerete}

A megvalósítás intézményi keretét rendkívül röviden, mindössze 2 oldal terjedelemben ismerteti a dokumentum. A városfejlesztés feladatait a 2009-ben létrehozott, önkormányzati tulajdonban lévő Erzsébetvárosi Fejlesztési és Beruházási Kft. (Erzsébetváros Kft.) fogja ellátni. A társasági közfeladat ellátásának a jogi alapja önkormányzati rendelet vagy alapszerződés jelenti majd. A társaság vezetőjével és alkalmazottaival szembeni általános elvárásként szerepel, hogy városfejlesztési szemléletet képviseljenek (szemben a fenntartói, üzemeltetői szemlélettel). A társaság feladatai között az ATT-ben megfogalmazott fejlesztéshez kapcsolódó feladatok elvégzése szerepel. Ennek keretében - a SEM IX gyakorlatát alapul véve - a városrehabilitációs tevékenységek teljes spektruma említésre kerül; külső pénzügyi források felkutatása, ingatlanvásárlások bonyolítása, terület előkészítés, közterület rendezés irányítása, önkormányzati tulajdonú beruházások irányítása, kapcsolattartás a magán vállalkozásokkal, az ingatlan fejlesztések pénzügyi egyensúlyának biztosítása, kapcsolattartás az önkormányzattal.

Eredeti, nem a pályázati követelmények diktálta kezdeményezése az IVS-nek az „Európa Belváros Program” megindítása. Ennek keretében Erzsébetváros, Józsefváros, Terézváros önkormányzatai nyilvánították ki együttműködési szándékukat a kerületeik kiemelt értékkel bíró belvárosi részeit. Az együttmúködés az IVS szerint más szervezetek csatlakozásra is nyitott. (IVS: 130). Az együttmüködés átfogó célokat és programokat tartalmaz. 


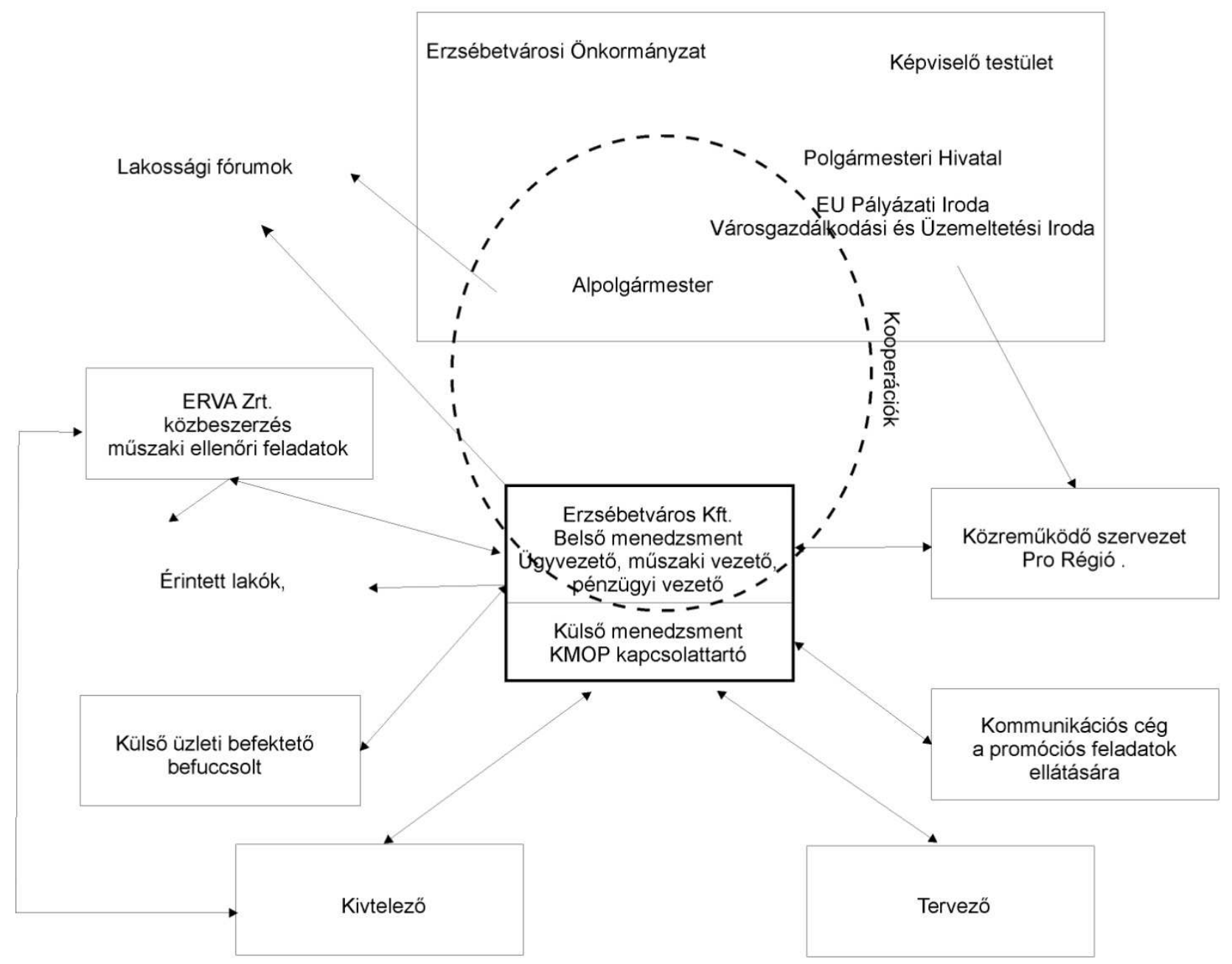

18. ábra: A Kultúra utcája beruházás megvalósításának szervezeti sémája

A projekt megvalósításának szervezeti keretéről Füle Gábor, az Erzsébetváros Kft. projektmenedzsere nyilatkozott részemre. Tájékoztatása szerint a projekt-menedzsment rendszer a megvalósítás során alakult ki. A pályázat előkészítését a kerületi alpolgármester koordinálta a polgármesteri hivatal szervezeti egységeiből (EU Pályázati Iroda, Városgazdálkodási és Üzemeltetési Iroda, Jogi Iroda) álló team készítette elő. A pályázati elvárások kapcsán ismert volt, hogy városfejlesztési társaságot kell létrehozni a támogatási szerződés megkötéséig. Bár ahogy az ATT-ben szerepelt, felmerült az Erzsébetvárosi Vagyonkezelö Zrt. (ERVA) bevonása, végül egy új cég, az Erzsébetváros Kft. létrehozatala mellett döntött az önkormányzat. Az önkormányzat elképzelése az volt, hogy cég létrejöttét követően az IVS-ben szereplő akcióterületi megújítások koordinálása lesz a feladata. A projekt fejlesztési szakaszban már a háromszemélyes Erzsébetváros Kft. koordinálta a munkákat a tervezésben részt vevő három tervező irodával. A cégvezető kezdetben korábbi ERVA-s munkatárs volt, aki az fejlesztésre tervezett ingatlanok állapotával tisztában volt, beruházási gyakorlattal rendelkezett. A támogatási szerződés megkötésére került sor a kiviteli tervek készítésére, majd ezt követően a kivitelezésre. 
A projekt-megvalósítás koordinálásának fontos eleme volt a heti rendszerességgel (keddenként) megtartott kooperációs értekezlet a projektért felelős alpolgármesternél. Ezen az Erzsébetváros Kft. menedzsmentje referált az aktuális történésekről. Az egyeztetéseken a polgármesteri hivatal érintett egyéb irodái is részt vettek (Városgazdálkodási és Üzemeltetési Iroda, Pénzügyi Iroda).

Az Erzsébetváros Kft. egy külső és belső menedzsment részre oszlott, a belső menedzsment (projekt menedzser, pénzügyi menedzser, müszaki vezető) a beruházás megvalósítást felügyelte, illetve az önkormányzattal való kapcsolattartást végezte. A külsős menedzsment feladata a közreműködő szervezettel (Pro Régió) való kapcsolattartás, jelentések, beszámolók elkészítése volt. A projekt menedzser véleménye szerint az önálló projekt társaság müködése sokban segítette a projekt megvalósítását. Az önálló szervezet rugalmasabban, gyorsabban és feladat orientáltabban tudott dolgozni, mint egy önkormányzati iroda, viszont a belső projekt menedzsment révén a Kft. vezetőinek kellő ismerete volt a polgármesteri hivatal müködéséről, és megvoltak személyes kapcsolataik, ami a napi ügyintézést jelentősen segítették. Ez egy teljesen külsős projekt menedzsment cégnél nem müködhetett volna ennyire gördülékenyen.

A projekt tartalmának a lakossági egyeztetését a felelős alpolgármester és az Erzsébetváros Kft. menedzsmentje végezte. A fejlesztések kapcsán megszűnő lakásokból a lakók kiköltöztetését, cserelakás biztosítását az ERVA Zrt, Erzsébetváros Kft, és a Városgazdálkodási Iroda közösen végezte. A promóciós feladatokra a projekt záró szakaszában egy kommunikációs céget bízott meg az Erzsébetváros Kft. A kivitelezés közbeszerzésének lebonyolítását és a müszaki ellenőri feladatok ellátását az ERVS Zrt. végezte az önkormányzat nevében.

A Pro Régióval való együttmüködésről a projekt menedzser keserü tapasztalatokat osztott meg. A nevében közremüködő szervezet valójában ellenőri feladatokat látott el minimális rugalmassággal. A szervezettel való rugalmas együttmüködést az sem könnyítette, hogy a Pro Régió feladat finanszírozási szerződést kötött a Nemzeti Fejlesztési Ügynökséggel. Vagyis közremüködői díjukat az ügyiratok száma alapján kapták, ami elképzelhető, hogy az ügyiratszám növelésére motiválta a szervezetet.

Az időközben begyürüző ingatlanpiaci és gazdasági válságnak nagyban betudható Füle Gábor véleménye szerint a beruházás katalizátor hatása egyelőre nem mérhető. Mivel újabb pályázati források nincsenek kilátásban, a városrehabilitációs piaci alapú modellje jelenleg nem müködik, az önkormányzat a cég tevékenységét müszaki ellenőri feladatok végzésére korlátozza. A kerület 
fejlesztési beruházások tervezése és lebonyolítása az ERVAS Zrt. valamint a Városgazdálkodási Iroda kooperációjában valósul meg. Ugyancsak nincsenek kézzel fogható eredményei az VI-VIIVIII. kerületek együttműködése érdekében létrehozott Európa Belvárosa Programnak.

\subsubsection{Budapest Európa Belvárosa Kulturális-gazdaság Fejlesztési Program, Józsefváros Palotanegyed}

\section{$\underline{\text { Az akcióterület helye az IVS-ben }}$}

Józsefváros IVS-e két akcióterületet jelöl ki, az egyik a Magdolna negyed, a másik a Palota-negyed. Ez utóbbi esetében a beavatkozás célja a terület komplex fejlesztése, a „jelenlegi szük belváros kiterjesztése” (IVS 3: 35). Az akcióterületek a kerület 11 kerületrésze közül csak kettőre terjednek ki, azokat azonban teljes mértékben lefedik. (Lásd 4. számú melléklet)

Az IVS a kerület egészére értelmezendő célként fogalmazza meg az önkormányzati lakásportfólió átstrukturálását, a társadalmi sokszínűség megőrzése mellett a közösség fejlesztés koncentrált eszközeivel kívánja a kerület népességmegtartó- és vonzerejét növelni. A városrész céljai között a „,kerület közterületeinek, zöldfelületeinek, mennyiségi és minöség növelése, a parkolási problémák kezelése, vonzó, korszerü és fenntartható lakókörnyezet létrehozása” szerepel célként. A Palota negyed specifikus céljai között a munkahelyteremtés, kreatív miliő kialakítása, diáknegyed funkció erősítése, az épületvagyon hosszú távú fenntarthatóságának biztosítása szerepel. (ATT: 10)

\section{$\underline{\text { Az akcióterületi tervben megfogalmazott célok és eredmények }}$}

Az ATT a terület problémái között a leromlott épületállományt és a funkcióvesztett üzlethelységeket említi meg, mely elhanyagoltság miatt a közterületi rendezettség- és biztonságérzet is jelentősen sérül. (ATT: 21) A demográfia helyzet tekintetében problémaként mutatja be a tanulmány az 1990-es évektől folyamatosan (42 885 főről 28073 főre) csökkenő népességszámot, illetve az egyszemélyes háztartások kiemelkedősen magas számát. (ATT: 35) A terület önkormányzati lakástulajdona az 90-es évek 40\%-os arányáról 2006-ra 17\%-ra csökkent. Bár az arány alacsony, azonban a fővárosi kerületek átlagához képest még mindig magasnak mondható. (ATT:36) Az önkormányzati lakásállomány komfortfokozatát az alacsony minőség jellemzi. Józsefvárosról általánosságban elmondható, hogy a jövedelmi és foglalkoztatási viszonyok alacsonyabbak a fővárosi átlagnál, azonban a kerületen belül jelentős eltérések figyelhetők meg. A Palotanegyedben a gazdaságilag aktív népesség aránya 54,8\% ami a kerületi átlagnál magasabb, de a fővárosi átlag alatti (ATT: 39). Az ATT a kerületrész fő problémájának a fokozatosan öregedő 
népesség és a negyed lehetőségeihez mérten rendkívül alacsony vonzerejét határozza meg a leromlott állapotú és kihasználatlan üzlethelységek okozóiként. (ATT: 40). A terület neoreneszánsz, neoklasszikus, eklektikus és szecessziós épületállománya, a meglévő belső udvarok hálózata, a terület oktatási intézményei valamint az itt élö szolidáris lakosságot nevezi meg az ATT a megújítás lehetséges erőforrásaiként. A tanulmány a szabályozási terv kapcsán kiemeli, hogy a „lassú és belső változásokra épülő programot támogatja, és akadályozza a gyors, csak külső erőkre épülö változásokat. (ATT: 16)

Az ATT értelmében a kerületrész hosszú távú gazdaságfejlesztési célja az önfenntartó és a versenyképesség növelése a területen. Társadalmi célok között a sokszínủ és szolidáris közösség létrehozása, kerületi határokon átnyúló térszerkezet kialakítása, kedvezőtlen demográfiai folyamatok mérséklése, negyed értékeinek megőrzése szerepel. Környezeti célok között a magas színvonalú lakókörnyezet kialakítása a hosszú távú cél. (ATT:106)

Ennek érdekében középtávon a gazdasági aktivitást, a jövedelemtermelő képességet, a helyi munkaerőpiacot kell fejleszteni valamint „,kreatív innovatív miliôt” kell alkotni. (ATT: 80). Környezeti szempontból a belvárosi terület környezetterhelését kell csökkenteni, illetve a köz- és közösségi tereket hálózatba kell szervezni. A fenti célokat a közösség bevonásával, magas színvonalú lakhatás biztosításával, a terület imázsának a javításával kell elérni. (ATT: 106) A középtávú célok eléréséhez a KMOP pályázat keretében a következő projektek kerültek meghatározásra:

19. táblázat: Budapest Európa Belvárosa - Józsefváros Palotanegyed ATT: a projekt keretében megvalósuló fejlesztések (ATT: 172)

\begin{tabular}{|l|c|}
\hline \multicolumn{1}{|c|}{ Projekt elem } & $\begin{array}{c}\text { Összes költség } \\
\text { mill. Ft (nettó) }\end{array}$ \\
\hline Városkép - Egységes díszvilágítási rendszer kialakítása & 46,9 \\
\hline $\begin{array}{l}\text { Örökségvédelem - Horánszky u. 13. fóvárosi védettségü épület felújítása, } \\
\text { funkcióváltása, InfoBox, diákcentrum }\end{array}$ & 451,5 \\
\hline $\begin{array}{l}\text { Közlekedésszervezés - Egységes gyalogos- vegyes forgalmú közterületi } \\
\text { rendszer kialakítása, ,korabeli” hangulat felidézése, egységes } \\
\text { díszvilágítás, közterületek felújítása, csak egyoldali parkolás }\end{array}$ & 465,5 \\
\hline Gazdaságfejlesztés - Speciális piacok projekt, Baedeker projekt & 61,7 \\
\hline Promóció - Identitást erősítő programok & 10,8 \\
\hline Szervezés- Projekt menedzsment & $\mathbf{1 3 3 , 6}$ \\
\hline Összesen & $\mathbf{1 3 2 , 6}$ \\
\hline
\end{tabular}




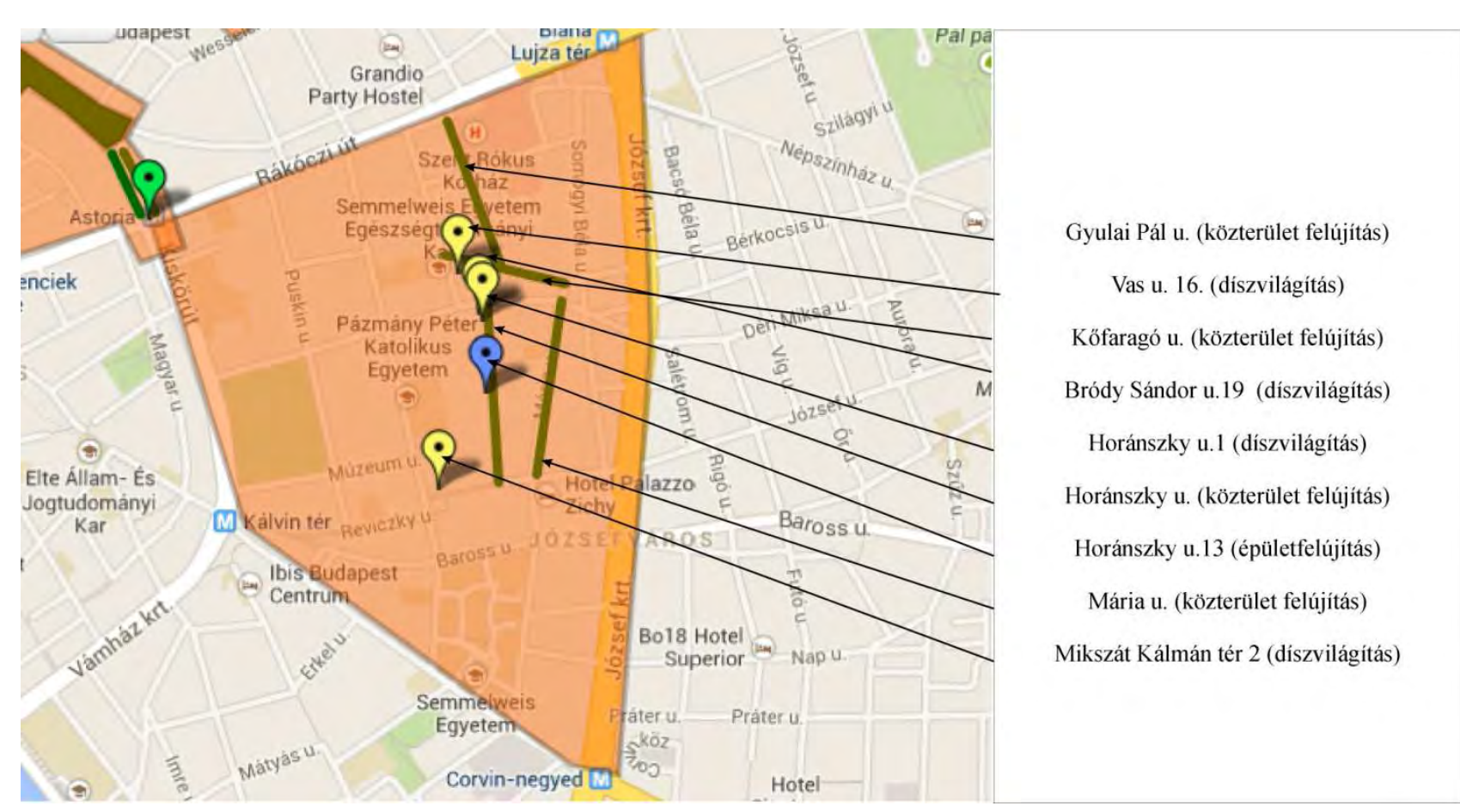

19. ábra: Józsefváros Palotanegyed beruházás keretében megvalósuló épített projektelemek.

A projekt készítői a fejlesztések multiplikátor hatását remélik, vagyis a program keretében a helyi gazdaságba befektetett erőforrások által többlet kereslet generálását. A multiplikátor hatás a magánbefektetések révén első sorban a szállodai beruházások megjelenését eredményezi. Fontosnak tekinti a dokumentum a költségvetési bevételek szempontjából generálódó multiplikátor hatást, de szintén kiemeli a területen élők közötti kapcsolati hálóra gyakorolt többszöröző hatás jelentőségét. (ATT: 101) Az ATT a KMOP pályázaton kívül megvalósuló tevékenységek között a közterületek további megújulását (Kis csibész tér), a homlokzatmegújítási programot, a Józsefvárosi Ifjúsági Vállalkozói Programot említi. (ATT: 95) A területen a magán szféra bevonásával megvalósításra kerülő fejlesztések között a parkolóhely-fejlesztés, homlokzat felújítások szerepelnek, míg a magánszféra öt ingatlanfejlesztési beruházását prognosztizálja a dokumentum. Ezek közül a Lőrinc pap téri hotelfejlesztés megvalósult, a Terfort u. 3-5 és Rökk Sz. út. 4. alatti hotelberuházások a tervezés, míg a Horánszky u. 16 és Mária u. 4 alatti beruházások a forráskeresés stádiumában voltak a dokumentum készítésekor. (ATT: 145)

A dokumentum felhívja a figyelmet a „csodavárás” problémájára, a gyors és jelentős sikerek iránti önkormányzati és lakossági elvárások csapdájára. A dokumentum problémaként jelzi, hogy „,a tradicionálisan kialakult vertikális mozgások (kijárás, ígérgetés) helyett, horizontális kooperációra van szükség, amelyet nehezen lehet elsajátítani.” (ATT: 141) 
A projekt kivitelezése a Mária utca esetében még a támogatási szerződés megkötése előtt megkezdődött, és 2010 végére elkészült. A többi közterület (Horánszky u., Kőfaragó u., Guttenberg u.) felújítása 2011 őszétől 2012 augusztusági tartott. Ennél lényegesen gyorsabb volt a díszvilágítás kivitelezése, amely 1-2 hónap alatt elkészült mind az öt érintett épületre.

A beruházás végén elégedettségi felmérést végeztetett az önkormányzat, amely tanulsága szerint 70\%-ban elégedettek voltak a megkérdezettek a projekt eredményével. Ezt az arányt a projekt menedzsere jónak ítéli. A projekt legsikeresebb elemeinek a közterületek megújítását, illetve a közösségi rendezvényeket tartotta a projekt menedzser. Az elkészült infobox-diákcentruminkutbátorház esetén pedig majd az üzemletetésen fog múlni mennyire lesz sikeres.

\section{A projekt megvalósításának szervezeti kerete}

Az akcióterületi terv szerint a projekt gazdája Budapest Józsefváros Önkormányzata, míg a kapcsolattartó projektmenedzser a Rév8 Zrt vezérigazgatója, Alföldi György. Az akcióterületi menedzsment szervezetként az IVS-t és az ATT-t készítő, 1997-ben megalapított Rév8 Józsefvárosi Rehabilitációs és Városfejlesztési Zrt. (Rév8) kerül megjelölésre. Ez a döntés nem meglepő, annak ismeretében, hogy a 61\%-ban a Józsefvárosi, 39\%-ban Fővárosi Önkormányzati tulajdonban lévő városrehabilitációs társaság, a SEM IX. Zrt. mellet a második hosszú ideje működő köztulajdonban lévő településfejlesztési társaság, melynek modelljét a Városfejlesztési Kézikönyvkészítő is példaként használták. (VKK 2009: 22)

A közérdekü és piaci személetet ötvöző, cca. 30 fős társaság feladatai:

- a kerületi város-rehabilitációs folyamatokban erőteljes szerepvállalás

- integrált város-rehabilitációs fejlesztések megvalósítása az, ami a kerület egészének fejlődésére kihat,

- a kerület lakásállomány-összetételének alapvető átstrukturálása

- vegyen részt a társadalmi kapcsolatok építésében

- tegye lehetővé termékeivel, szolgáltatatásával jelentős magántőke bevonást (ATT: 161)

A társaság fejlesztési dokumentációk, tanulmányok, pályázatok összeállítása mellett eddigi müködése során az önkormányzati vagyonelemek hasznosításából mintegy 6,7 mrd. Ft bevétellel és 5,2 mrd. Ft pályázati támogatás elnyerésével járult hozzá a kerületi fejlesztések forrásának megteremtéséhez. (ATT: 162) 


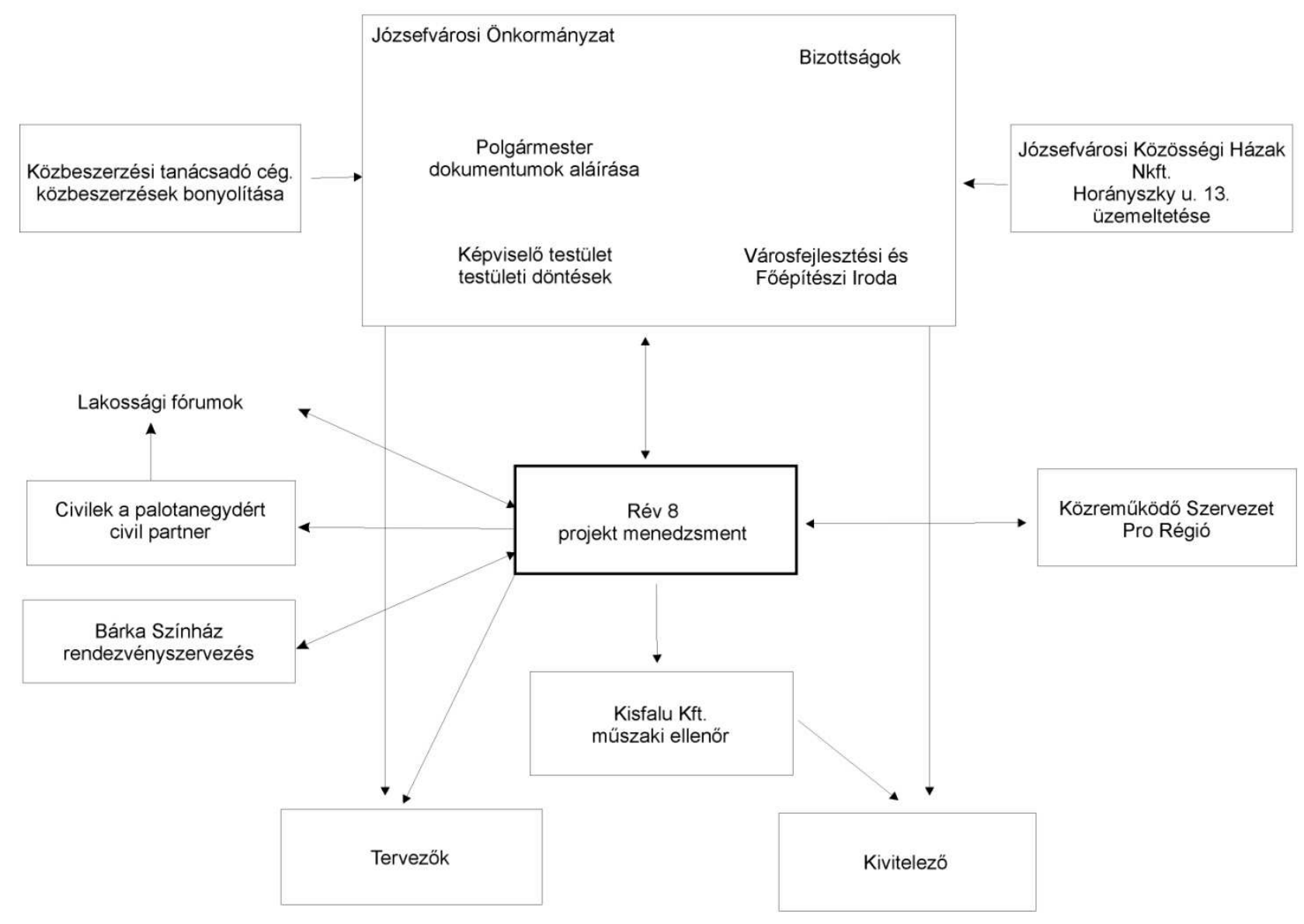

20. ábra: Józsefváros Palotanegyed 1. ütem beruházás megvalósításának szervezeti sémája

Az ATT a Corvin Sétány és a Magdolna Negyed programok tanulsága alapján azt a sommás következtetést vonja le, hogy az „ágazati elven müködö önkormányzati rendszer nem alkalmas akcióterületre fókuszáló, integrált beavatkozás végig vitelére”. Ezért tekinti a Rév8-hoz hasonló integrált városfejlesztési társaság munkaszervezetét a komplex városmegújítási akciók lebonyolításának elengedhetetlen feltételének. (ATT: 165)

A projekt megvalósításának folyamatáról Csete Zoltántól, az Európa Belvárosa projekt menedzserétől kaptam tájékoztatást. A cégnek nincs közszolgáltatási szerződése az önkormányzattal, mindig egyes projektek megvalósítására kötnek szerződést. Előbb a pályázat készítésre, majd siker esetén a projekt lebonyolítására. A társaságnak nincs döntési, illetve szerződés kötési kompetenciája. A társaság előkészíti a döntéseket, a döntéseket az önkormányzat hozza, a szerződéseket szintén az önkormányzat köti.

A beruházás müszaki ellenőrzési feladatait az önkormányzat vagyonkezelő cége a Kisfalu Kft. látta el. Ez azért is indokolt, mert a felújított közterületek fenntartását ez a társaság végzi. A projekttel kapcsolatos rendezvények szervezését pedig a Bárka színház végezte. 
A projekt során intenzív együttmüködés alakult ki a Civilek a Palotanegyedért szervezettel, ami a pályázat írásától a megvalósításig végigkísérte a projektet. A civil szervezet lakossági fórumokat is szervezett, melyek általában látogatottabbak voltak, mint az önkormányzat által szervezett fórumok. A civil szervezet rendszeresen lehetőséget kapott, hogy a kivitelezési helyszíneken kapjon tájékoztatást a projekt előrehaladásáról. A lakossági egyeztetések jelentős része a forgalomcsillapítási intézkedésekkel összefüggésben történt. A lakosság sokallta az eredeti tervekben megszüntetésre tervezett parkolóhelyek számát. Az egyeztetések eredményeképpen végül több parkolóhely maradt meg a korábban tervezetnél.

A közreműködő szervezettel kapcsolatban itt is elhangzott, hogy a projekt megvalósítása kapcsán a rugalmatlansága, irracionális elvárásai nehezítették az együttmüködést. Példaként az Első Emelet koncertjét említette a riportalany, amely kapcsán a Pro Régió elvárása az volt, hogy több árajánlat közül kerüljön a már elfogadott előadó kiválasztásra.

Csete Zoltán véleménye szerint a RÉV 8 nagy előnye, hogy hosszútávon képes tervezni, nem csak egyes pályázati kiírásokra. Fontos, hogy a pályázatok előkészítésétől a megvalósításig jelen vannak az egyes projektekben. Ennek is betudható, hogy több projekt esetén további fejlesztési ütemekre is sor kerül, mint az Európa Belváros projekt esetében, ahol most készítik elő a második ütemet. Ezt vélhetően azonban már nem EU-s forrásból, hanem a fővárosi önkormányzat által kiírásra kerülő TÉR-KÖZ pályázat keretében tervezik megvalósítani. A sikeres működés ellenére, a Corvin sétány beruházás lelassulása, illetve a pályázati források elapadása miatt a korábban 30 fős társaságjelentős mértékben zsugorodott. Ez egyenes következménye annak, hogy aktuális projektek kapcsán kötött szerződésekből finanszírozzák magukat. A létszám csökkenés következtében a társaság elvesztette képességét komplex projektek lebonyolítására. Ezzel párhuzamosan az önkormányzat döntése alapján egyre több beruházási feladat kerül át a korábban csak üzemletetői feladatokat ellátó Kisfalu Kft-hez. Ennek indoka, hogy a korábbi beruházások kapcsán előfordultak nézeteltérések a beruházást követően az üzemeltetésre való átvétel során. Amennyiben a két feladat egy kézbe kerül, ez a probléma automatikusan megszünik. Az önkormányzat Főépítészi Irodája is egyre nagyobb részt vesz ki a közterületi fejlesztések megvalósításából. 


\subsubsection{Sashalom városközpont komplex városrehabilitációja}

\section{$\underline{\text { Az akcióterület helye az IVS-ben }}$}

A XVI. kerület négy fejlesztési pillért határoz meg: család és biztonság, egészséges életmód, kertvárosi környezet, helyi identitás. Ezekhez kapcsolódóan összesen 9 db akcióterületet kerül a dokumentumban kijelölésre, megjelölve azokon belül a fejlesztési és potenciális fejlesztési területeket. Ezek között első helyen szerepel Sashalom városközpont rehabilitációjának akcióterülete. (Lásd 4. számú melléklet)

Az IVS szerint az akcióterület fejlesztésének célja „a település hagyományos arculatához illeszkedő kereskedelmi, szolgáltatási, közösségi részközpont kialakítása, zöldterületek közösségi célú revitalizációja, új zöldterületek kialakítása, pihenőövezetek kialakítása, a humán közszolgáltatások intézményrendszerének fejlesztése, valamint a parkolási feltételek javítása.” (ATT: 57)

\section{Az akcióterületi tervben megfogalmazott célok és eredmények}

Az ATT településszerkezeti problémának írja le, hogy „a kerületnek nincs kiépült, centralizált, kulturális, igazgatási, kereskedelmi funkciókat teljes értéküen ellátó központja.” (ATT: 19) A településrészi központok funkcióhiányossá váltak mára. A területen működő piac iránti fogyasztói igények tekintetében készült kutatás alapján a vonzáskörzet a terület 5-10 perces autóúttal elérhető vonzáskörzetére terjed ki, ami alapján a potenciális napi vásárlóközönség cca. 10000 fő körüli, melynek vásárlóereje 30\%-kal meghaladja az országos átlagot. (ATT: 23)

20. táblázat: Sashalom városközpont komplex rehabilitációja ATT: a pályázat tartalma és költségei (ATT: 60-61)

\begin{tabular}{|l|r|}
\hline \multicolumn{1}{|c|}{ Projekt elem } & $\begin{array}{r}\text { Összes költség } \\
\text { mill. Ft (nettó) }\end{array}$ \\
\hline Havashalom park - kerti bútor & 5,134 \\
\hline Vízellátás és öntözhöhálózat & 20,374 \\
\hline Havashalom park - sportpályák, játszótér & 85,549 \\
\hline Szabadidö-, sportcsarnok építése & 210,928 \\
\hline Havashalom park zöldfelület & 48,601 \\
\hline Havashalom park járóburkolat & 28,959 \\
\hline Piac és Margit utca zöldfelület & 49,16 \\
\hline Sashalmi sétány zöldfelület & 25,852 \\
\hline Közvilágítás korszerüsítése & 31,636 \\
\hline Ökopiac létesítése & 178,722 \\
\hline Kkv. Szolgáltatóház felújítása & 3,000 \\
\hline Sashalmi sétány & 59,525 \\
\hline Belső Veres Péter / Vörösmajor / Margit u. építése & 92,384 \\
\hline Térfigyelö rendszer & 3,332 \\
\hline Elökészítés (tervezés, pályázatírás) & 36,857 \\
\hline
\end{tabular}




\begin{tabular}{|l|r|}
\hline Promóció & 9,100 \\
\hline Szervezés, projektmenedzsment & 35,734 \\
\hline Egyéb & 14,000 \\
\hline Összesen & $\mathbf{9 3 9 , 0 0 4}$ \\
\hline
\end{tabular}

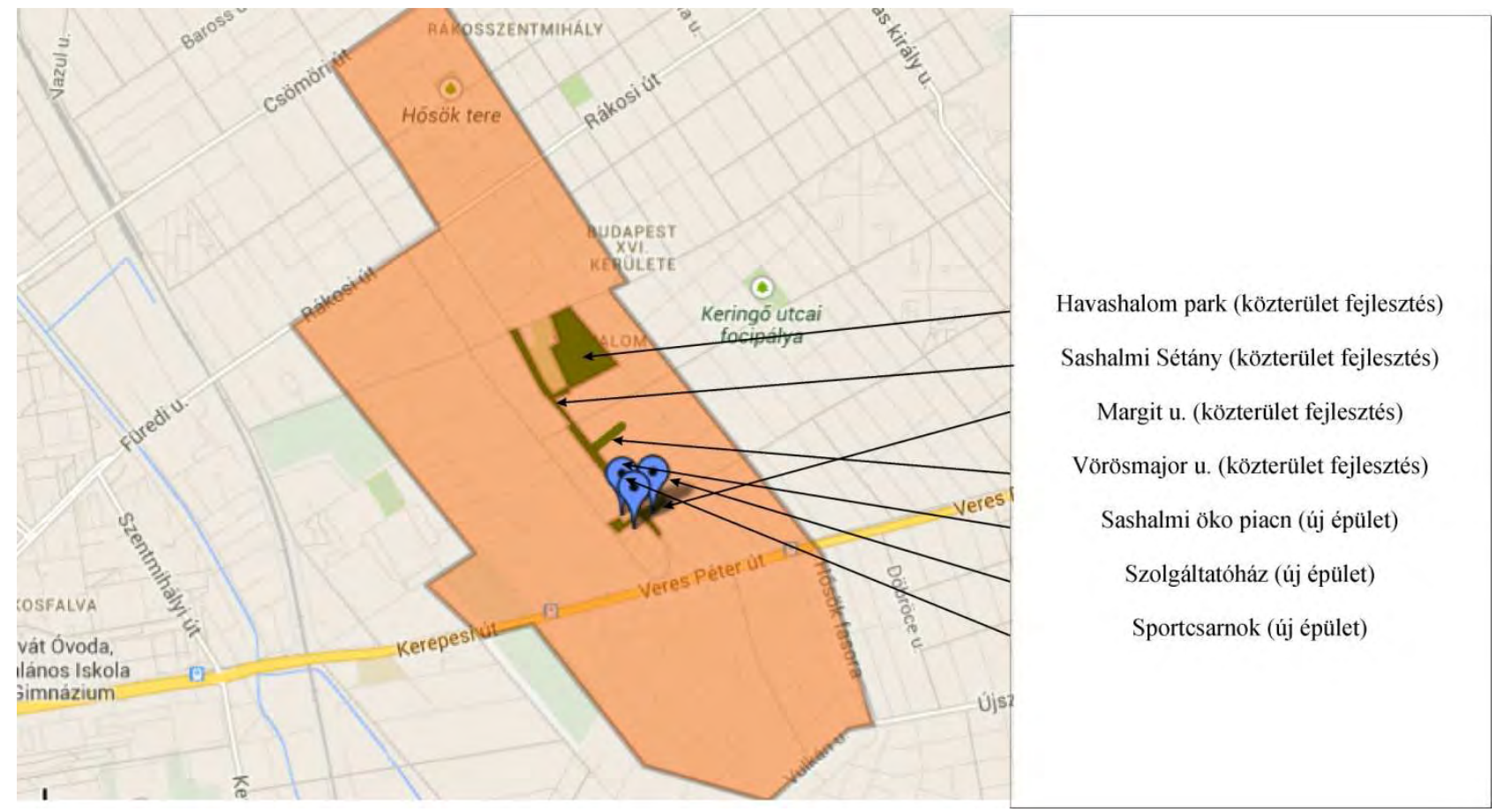

21. ábra: Sashalom városközpont beruházás keretében megvalósuló épített projektelemek.

A dokumentum a Sashalmi piac környezetében a beruházás hatására az ingatlanpiaci tendenciák átalakulását prognosztizálja. A piac közvetlen környezetében a kereskedelmi funkciókra alkalmas ingatlanok árának „komolyabb mértéku” növekedésére számít. Szintén árnövelö hatása lehet a fejlesztésnek a piactól néhány utca távolságra lévő lakóingatlanok esetében. ${ }^{42}$ (ATT: 22)

A dokumentum a Veres Péter - Thököly u. kereszteződésében kereskedelmi szolgáltatóház építését prognosztizálja 1,2-1,8 mrd. Ft értékben. A beruházás megindításához azonban a P+R parkolóhelyek számát a fővárosi követelményeknél alacsonyabban kell megállítani. A jelenlegi fejlesztéshez kapcsolódóan a piac melletti CBA üzlet bérlője is jelezte felújítási szándékát. Egyéb fejlesztési szándékról a dokumentum készítőinek nincs tudomása. Az önkormányzat a pályázaton kívüli forrásokból $900 \mathrm{~m} 2$ piaccsarnok és $360 \mathrm{~m} 2$ üzlet és raktárhelység kialakítását terveztet mintegy 155 millió Ft értékben. (ATT: 46) Ehhez kapcsolódóan kerül sor a terület elektromos hálózatának felújítására, illetve a Talpfa utca mintegy 80 m-es szakaszának felújítása.

\footnotetext{
${ }^{42}$ Az IVS tanulsága alapján (IVS: 59) ebben a térségben az önkormányzatnak a piacon kívül csak egy ingatlantulajdona van, így a projekt által elért ingatlannövelés közvetlen hasznából csak igen korlátozott mértékben részesül.
} 
A szerződéskötésre 2010 januárjában került sor és 2011 szeptemberében befejeződött a kivitelezés. A beruházás valamennyi tervezett eleme megvalósult. A megújult közterületeket és parkot a korábbinál lényegesen nagyobb számú közönség látogatja. A piac felújítása pedig egy több éve tervezett fejlesztés volt, amit nagyon várt a helyi lakosság.

\section{A projekt megvalósításának szervezeti kerete}

Az ATT kifejti, hogy a XVI. kerületi önkormányzat ez idáig polgármesteri vagy alpolgármesteri irányítással, a saját szervezeti keretei között, a polgármesteri hivatal érintett irodáinak és ügyosztályainak bevonásával sikeresen bonyolított le jelentősebb fejlesztéseket. A sashalmi fejlesztési program előkészítésében a föépítész és a környezetvédelmi irodavezető töltött be kulcsszerepet. Azonban a KMOP pályázati kiírásban szereplő kötelezettségekhez igazodóan az önkormányzat Városfejlesztési társaságot alapít. (ATT: 71) A 18/2009 (VI.1.) rendelet értelmében az önkormányzat 3 millió Ft-os tőkével megalapította a XVI. kerületi Városfejlesztő Társaságot, melynek elsődleges feladata a Sashalom városközpont komplex rehabilitációja projekt lebonyolítása. A társasággal való kapcsolattartás a polgármester feladata, mely tevékenységét a polgármesteri hivatallal kötött szerződése alapján látja el. A társaság döntés-előkészítő és végrehajtó tevékenységét a polgármesteri hivatal kijelölt szervezet ellenőrzi. A társaság vezetésére EU szakközgazdász és projektmenedzseri végzettségü vezető kerül majd kijelölésre az ATT értelmében. Tehát a társaság döntés-előkészítő, lebonyolító és ellenőrző feladatokat lát el, valamint, feladatai közé tartozik még a magánszféra és a közszféra együttmüködésének segítése.

A projekt megvalósításáról Szabó Ottóval, a sashalmi önkormányzat Polgármesteri Kabinetének Pályázatai Referensével készítettem interjút. Ö megerősítette az ATT-ben leírtakat, miszerint a pályázati kiírás elvárásai miatt létrehozták a 100\%-os önkormányzati tulajdonban lévő XVI. kerületi Városfejlesztő Kft-t. A cég a projekt megvalósítása alatt a piac felügyeleti feladatokat látta el, majd a megvalósítást követően megszünt. Az interjúalanyom véleménye szerint a XVI. kerületben nincs olyan ingatlanvagyon, illetve olyan volumenủ beruházások, melyek a ferencvárosihoz hasonló városfejlesztő társaság működtetését indokolttá tenné.

A projekt előkészítése és később a bonyolítása ennek ellenére javarészt az önkormányzat szervezetében belül marad, több szervezeti egység között megosztva a feladatokat. A Kerületfejlesztési és Üzemeltetési Iroda a piac létesítését, a Környezetvédelmi Iroda a közterületi fejlesztéseket koordinálta. A projekt menedzsmentjét ellátó team önkormányzati szervezeten belüli résztvevői voltak még a Közbeszerzési Iroda, Költségvetési és Pénzügyi Osztály, valamint a fejlesztési koncepciót leginkább ismerő főépítész volt. A menedzsment külső tagjai voltak a 
pályázat írást majd később monitoringot készítő külső szakértők. A projekt menedzsment heti rendszerességgel tartott üléseket a polgármester vezetésével.

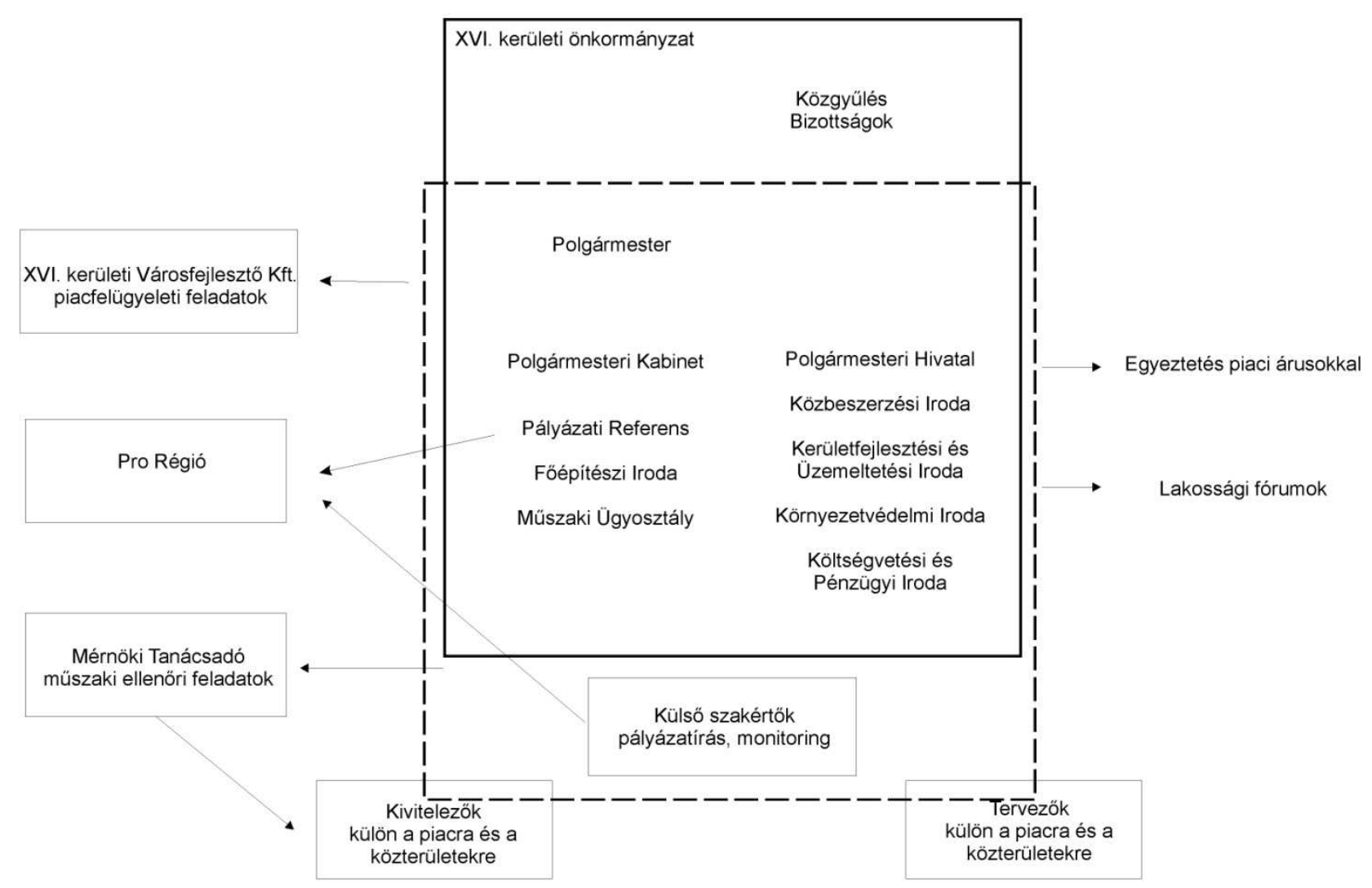

22. ábra: Sashalom városközpont komplex városmegújitás beruházás megvalósításának szervezeti sémája

A szerződéskötéseket követően került sor a tervezési majd kivitelezési közbeszerzések kiírására. A tervező, illetve később a generál kivitelező cégek a menedzsment üléseken ugyancsak résztvettek szükség szerint, hogy a vezetés első kézből értesülhessen az aktuális eseményekről, feladatokról.

A Pro Régióval való kapcsolattartást a Polgármesteri Kabinet pályázati referense végezte. Szabó Ottó beszámolója szerint nem volt különösebb gond az együttmüködéssel, annak ellenére, hogy történtek időjárási körülmények miatti csúszások a kivitelezésben, és egy alkalommal még szerződés-módosításra is sor került. A lakosságot fórumok keretében tájékoztatták a tervezett fejlesztésekről. A piac nyitvatartása kapcsán a piaci árusokkal történt több egyeztetés, mely során az a döntés született, hogy a projekt megvalósítása alatt is folyamatosan biztosítják a piac müködését.

A fejezetben leírtak összefoglalóját a dolgozat formai követelményeinek megfelelően a 3 . eredmények fejezet részeként közlöm. 


\section{Eredmények}

\subsection{Az átalakuló városi területek megújításának eszköztára}

A dolgozat első kutatási egysége a budapesti átalakuló városi területek megújításának lehetséges teljes urbanisztikai eszköztárát vizsgálta azért, hogy a stratégia-készítés és a szabadtér-megújítási projektek jelentőségét meg tudja határozni a többi lehetséges eszközhöz viszonyítva.

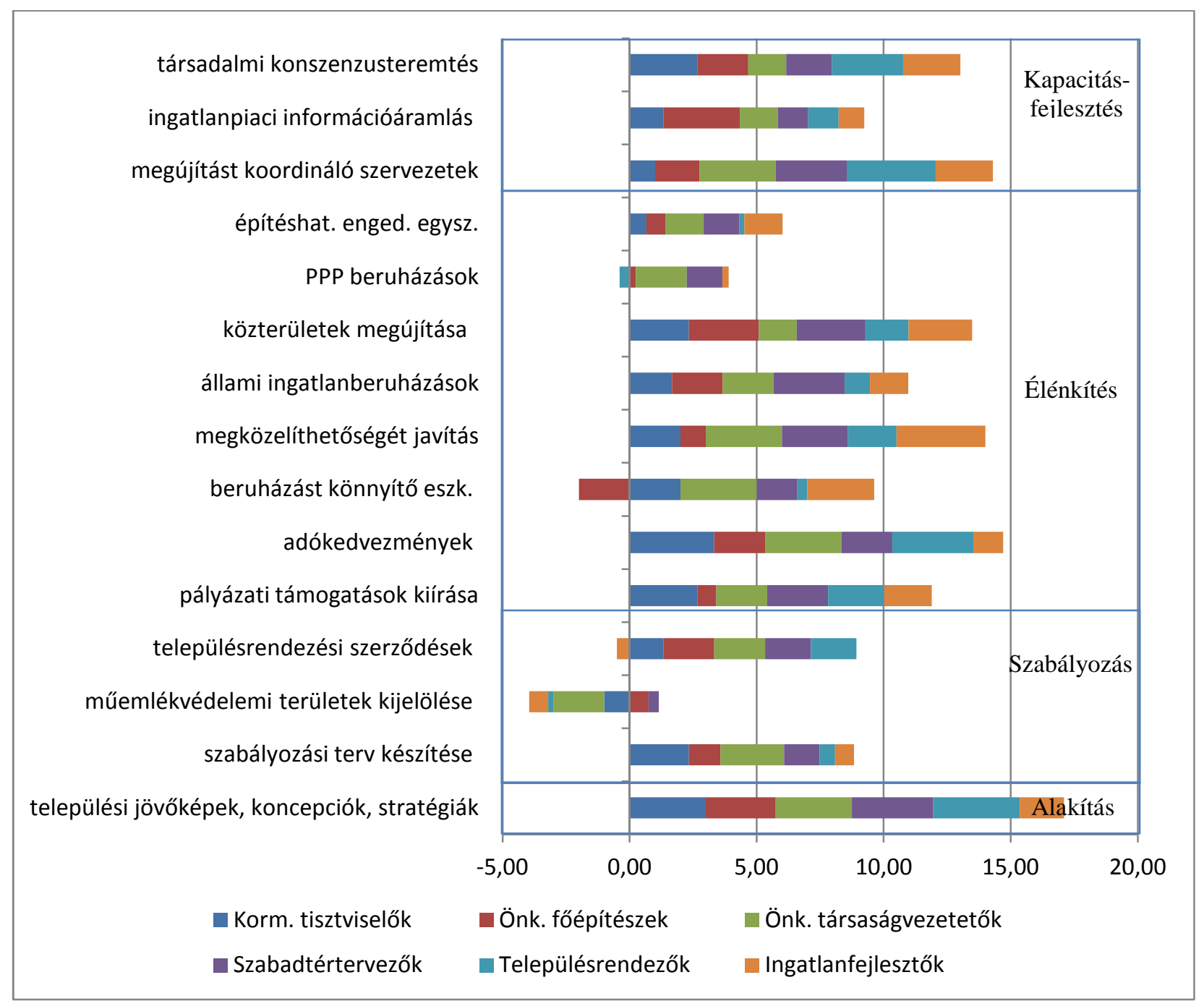

23. ábra: A fejlesztési környezetet befolyásoló beavatkozások jelentőségének összefoglalója az interjúalanyok csoportjai szerint. $^{43}$

A kvantitatív felmérésben szereplő egyedi válaszok alapján a felsorolt 15 eszköz közül a települési jövőképek, koncepciók, stratégiák kidolgozását (á 2,87) minősítették összességében a

\footnotetext{
${ }^{43}$ Az egyedi válaszok és a válaszadói csoportok átlagai alapján számított átlagértékek között természetesen minimális eltérés tapasztalható. Az eredmények értékelésekor az egyedi válaszok átlagai kerültek bemutatásra, azonban a grafikus megjelenítés során a válaszadói csoportok szerinti átlagok ábrázolja. Ennél ugyanis plusz információt szolgáltat, hogy melyik válaszadói csoport tartotta az egyes eszközöket nagyobb vagy kisebb jelentőségünek.
} 
legjelentősebb eszköznek a megkérdezettek a települések átalakuló területekeinek megújítása érdekében. Másodikként megújítást koordináló szervezet létrehozását (á 2,46), harmadikként pedig az átalakuló területek megújítását segítő adókedvezményeket (á 2,43) jelölték a megkérdezettek. Ugyancsak magas értéket kapott a szabadtér megújítási projektek (á 2,30) eszköze. Az eredmény teljes mértékben megerősíti a kutatás a stratégiai tervezés jelentőségére vonatkozó 2. hipotézist. A szabadtér megújítási beavatkozások a negyedik helyet szerezték meg a relatív rangsorban, így az eredmények nem támasztják egyértelmúen alá 3. hipotézist. A kvalitatív interjúkban elhangzottak azonban több esetben alátámasztották a szabadtér-megújítások városmegújítás katalizáló hatásait. Az kvantitatív felmérés eredményei alátámasztják a 4. hipotézist, mely szerint a település megújítást koordináló operatív szervezet jelentős mértékben segítheti a városmegújítási folyamatokat.

Az 24. ábra alapján jól érzékelhető, hogy a települési átalakuló területek megújítása szempontjából a fejlesztési környezet alakítása és az élénkítése eszközeit tartották a válaszadók a hatékonyabb, míg a szabályozás eszközeit a kevésbé hatékony állami, önkormányzati beavatkozási formáknak. A kutatás fontos eredménye, hogy a településmegújítás elősegítése kapcsán a településrendezés jelenleg legáltalánosabb eszközéről, a szabályozási tervezés jelentőségéről kérdezve az interjúalanyokat az összes megkérdezett válaszainak átlagát tekintve alacsony érték adódott (á $1,30)$.

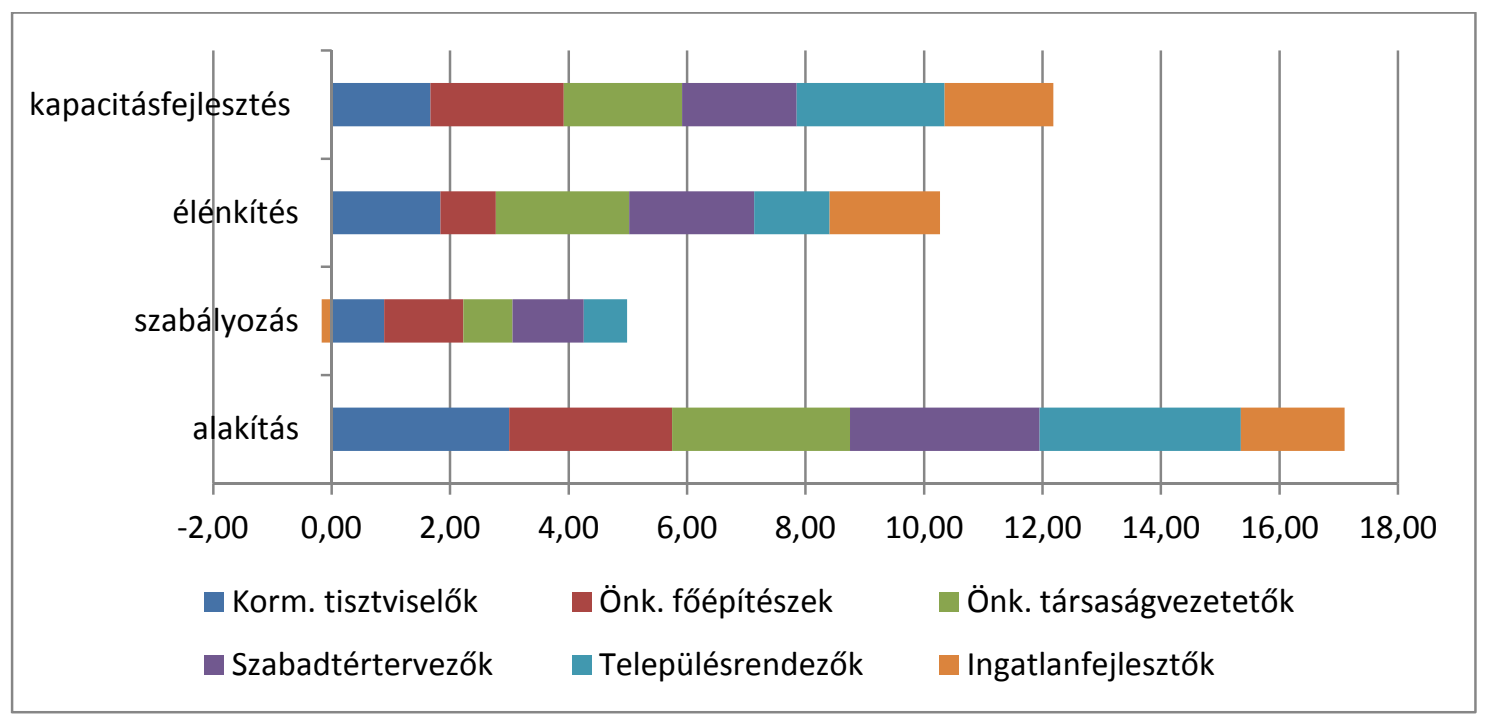

24. ábra: A fejlesztési környezetet befolyásoló beavatkozás típusok jelentőségének összefoglalója az interjúalanyok csoportjai szerint.

Különösen érdekes eredmény, hogy éppen a településrendezési terveket készítő tervezők válaszainak átlagértéke (á 0,60$)$ jelezte azt, hogy az eszköz nem hatékony az átalakuló városi 
területek megújításában. Ez az eredmény megerősíti azt az állítást, hogy a városi területek megújításának eszköztára önmaga is megújításra szorul.

Karakteres eredménnyel szolgál a beavatkozási típusok válaszadói-csoportokkal történő összehasonlítása. A 25. ábrán látható, hogy a fejlesztési környezet alakítása az ingatlanfejlesztők kivételével valamennyi megkérdezett csoportban a leginkább hatékony beavatkozási típusként került megjelölésre. Az ingatlanfejlesztők a fejlesztési környezet élénkítésének eszközeit sorolták első helyre. Másodikként az önkormányzati föépítészek, ingatlanfejlesztők és településrendezők egyaránt a kapacitásfejlesztés eszközeit jelölték. Ezzel szemben a kormányzati tisztviselök, az önkormányzati fejlesztési társaság vezetők és a szabadtértervezők az élénkítés típusú eszközöket tartották inkább fontosnak. A szabályozás típusú eszközöket az önkormányzati főépítészek kivételével mindenütt a legkevésbé hatékony eszközként jelenítették meg az átalakuló területek megújítása szempontjából. Az ingatlanfejlesztők csoportja a szabályozási eszközöket összességükben hátráltatónak, a megújulást nehezítőnek értékelték.

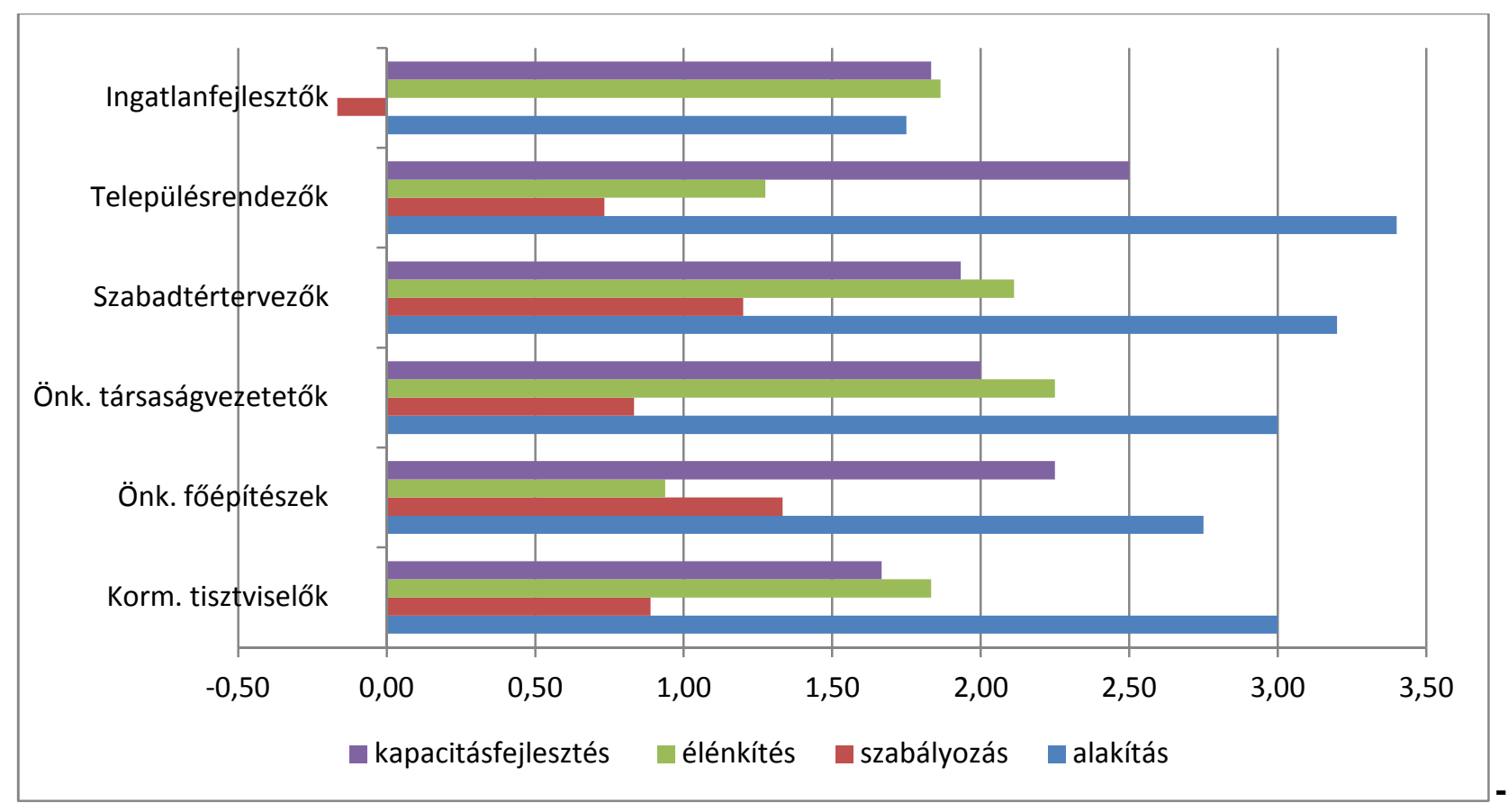

25. ábra: A fejlesztési környezetet befolyásoló beavatkozás típusok jelentőségének összefoglalója az interjúalanyok csoportjai szerint.

Az állami, önkormányzati beavatkozásokat összességükben valamennyi csoport a kismértékben (á 1,00) és a jelentős mértékben (á 2,00) meghatározó tényezők között értékelte. Meglepő módon a leginkább szkeptikusak a települési fóépítészek (á 1,40) voltak a beavatkozások jelentőségét illetően. Az ingatlanfejlesztők ugyancsak összességben kevésbé tartották meghatározónak az állami önkormányzati beavatkozásokat (á 1,44). Legnagyobb jelentőséget a szabadtértervezők és az 
önkormányzati társaságvezetők tulajdonítottak ezeknek a beavatkozásoknak (á 1,97). A kormányzati tisztviselők (á 1,69) és a településrendezők (á 1,55) a mérsékelt vélemények megfogalmazók közé tartoztak.

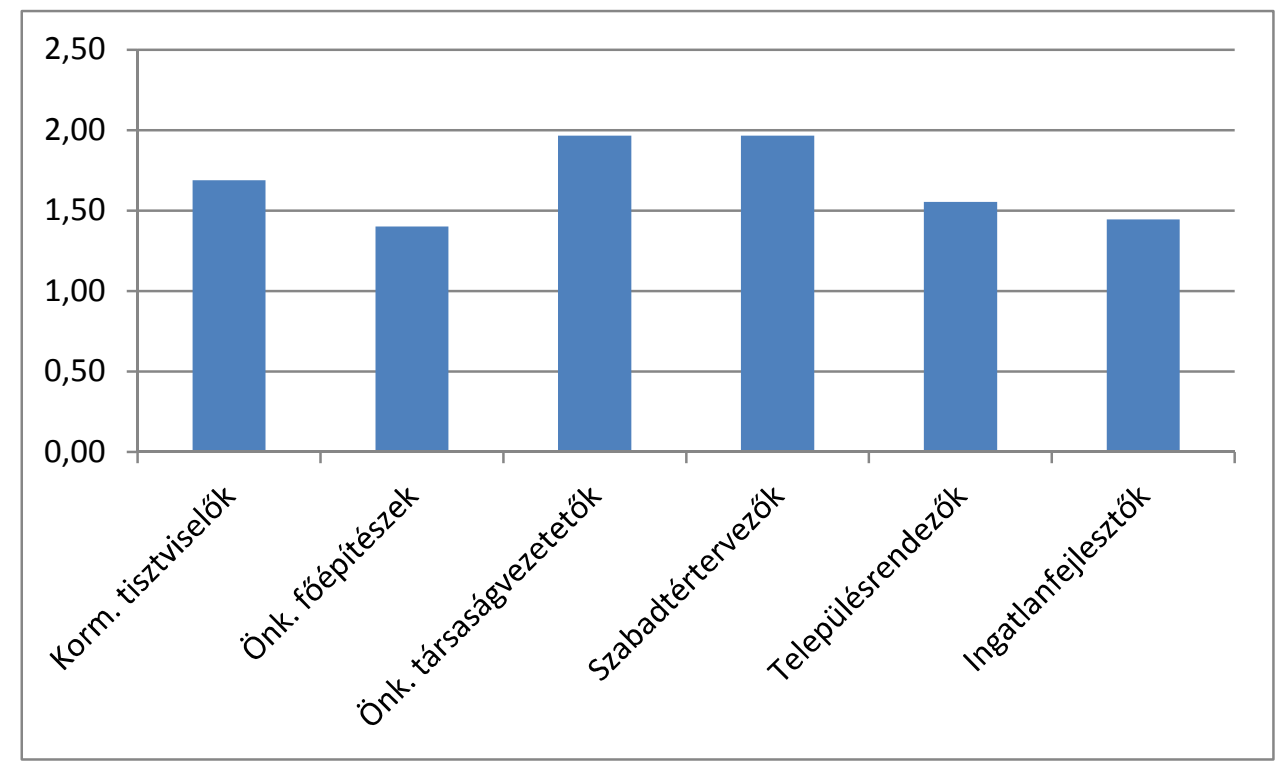

26. ábra: Az állam és az önkormányzatok beavatkozásának jelentősége az átalakuló városi területek megújításának folyamatába. A beavatkozások jelentőségének átlagának összege az interjúalanyok csoportjai szerint.

A kvalitatív interjúk során számos javaslatot fogalmaztak meg a válaszadók arról, hogy milyen szervezeti keretben tudnák a leginkább hatékonyan biztosítani a város az átalakuló területek megújításának tervezését. Itt az összvárosi szintű tervező iroda müködtetésétől, a kerületi szintű üzemeltetési és fejlesztési feladatokat ellátó menedzsment szervezeten át, az agglomerációs tanács hatáskörének kibővítését is említve egészen az egykori közmunkák tanácsához hasonló, a kormányzati és az EU-s politikákat is integráló szervezet egyaránt említésre került. Mindezek megerősítik a bevezetőben szereplő állítást, mely szerint fontos a jelenlegi városmegújítási eszközrendszer felülvizsgálata. Az IVS készítés gyakorlata kapcsán azt jelezték a megkérdezettek, hogy sok önkormányzat jelenleg nem tudja rendeltetése szerint alkalmazni a stratégia tervezés eszközével. Ez megkérdőjelezi a tanulmány 1. hipotézisét, a poszt-pozitivista fordulatról a tervezési gyakorlatban.

A kutatás értékes eredménye az interjúalanyok által megfogalmazott összesen 53 féle beavatkozási lehetőség az átalakuló városi területek megújítására vonatkozóan. Az alakítás/szabályozás/élénkítés/kapacitásfejlesztés eszközeinek széles tárházát bemutató javaslatok összefoglalóját a 11. táblázat tartalmazza. A javaslatok részletesebb kifejtését pedig a mellékletben közölt interjú kivonatok tartalmazzák. 


\subsection{Fővárosi szabadtérmegújítási stratégiák}

Az első kutatási egység egyik fontos konklúziója, hogy az átalakuló városi területek megújításának a fejlesztési stratégiai a leghatékonyabb eszközei. A második kutatási egység három szabadtérépítészeti stratégiát vizsgálva elemzi, hogy mennyire hatékony eszközei a bennük megfogalmazott célok megvalósításának. Ahogy azt a szakirodalmi fejezet jelezte, a stratégia tervezés poszt-pozitivista tervezési müfaj. Kérdés azonban, hogy a második kutatási egységben vizsgált stratégiák csak nevükben, vagy módszereikben is azok-e? Ennek elemzéséhez a stratégiai tervezés öt - Bryson féle (Bryson 2004: 9) - ismérvét tekintem át.

Mindhárom, vizsgált dokumentum készítése során alapvető cél volt a zöldfelület, zöldhálózat fejlesztéssel kapcsolatos stratégiai gondolkodás segítése. Ezt a meglévő állapot áttekintésével, a prioritások és jövőkép megjelölésével és az ehhez szükséges programok és projektek összeállításával be is töltik a dokumentumok.

A dokumentumok döntés-előkészítő, döntés-koordináló feladatukat különböző mértékben töltik be. A Pro Verde! döntés előkészítő dokumentum szintjén megrekedt, nem született megvalósításáról önkormányzati döntés, csupán áttételesen és jelentősen csökkentett tartalommal. A Margitsziget Stratégia elfogadásáról megszületett az önkormányzat határozata, azonban a folyamat ezt követően négy évre leállt, majd 2013-ban a stratégia alapján készült „fejlesztési terv” dokumentum mentén folytatódni látszik. Az AngyalZÖLD esetében a dokumentumot elfogadó önkormányzati határozatot követően a dokumentum beépült a került IVS-ébe, és a megvalósítását a kidolgozó szervezet megkezdte, ami azt jelentette, hogy folytatta zöldhálózat menedzselési tevékenységét, most már a stratégiában meghatározott projektek megvalósítását célul tüzve.

A szervezet müködésének hatékonyságjavítása valójában egyik dokumentumnak sem volt célja. A Pro Verde! az egész fővárosi önkormányzatra vonatkozóan határozta meg a tennivalókat, nem pontosítva a megvalósítás a szükséges forrás kereteket, nem meghatározva megvalósítás lehetséges szervezeti feltételeit. A Margitsziget Stratégia esetében gondnokság intézményének felállítása jelentheti a megvalósítás szervezeti keretét. A dokumentum kidolgozását koordináló Főkert Zrt., mely a gondnoki feladatok várományosa, nem tekintette a stratégai készítés feladatának a szervezeti müködésének áttekintését. Hasonló volt a helyzet az AngyalZÖLD stratégiát készíttető Környezetgazdálkodási Kft esetében, mely a dokumentumban bemutatja müködésének kereteit, azt azonban nem vizsgálja, hogy a szervezeti kerete megfelelő, vagy szükség lenne-e szervezeti módosításokra a stratégia hatékonyabb megvalósítása érdekében. Mindhárom stratégia foglalkozik a 
monitoring feladatokkal. A ProVerde! és a Margitsziget Stratégia esetében a monitorozásra nem került sor. Az AngyalZÖLD esetében a 2011-es felújítást megelőzően beszámoló készült a projektek megvalósulásáról, készült egy közparki minőségi kataszter, illetve reprezentatív telefonos közvéleménykutatás a

A szervezeten kívüli együttmüködés hatékonyságának növelését a Pro Verde! nem tekintette prioritásának, mivel kizárólag a fővárosi önkormányzat számára fogalmazott meg tennivalókat. A Margitsziget Stratégia ugyancsak a fővárosi önkormányzat számára fogalmazott meg feladatokat. Azonban, ha ennek esetében a szervezetet a zöldfelület fenntartóra (Főkert) értelmezzük, úgy ennek a szervezetnek és a külső, önkormányzati szervezetek, és ügyosztályok közötti együttmüködés hatékonyságának növelése a készítés fontos szempontja volt. Az AngyalZÖLD stratégia programjai között szerepelteti mind a zöldterület fenntartó, mind a kerületi önkormányzat egyéb intézményeinek, valamint a fővárosi önkormányzat kapcsolódó fejlesztéseit. A dokumentáció egyeztetésével tájékoztatja a társszervezeteket a fejlesztési szándékairól. A civil társadalom valódi megszólítását, a formális konzultáción túlmutató társadalmi együttmüködési intézményesített kereteinek kialakítását egyik tervezési folyamat sem tekintette valódi célnak. Mindazon által érdemes felfigyelni arra, hogy mindhárom stratégia több társadalmi partnerséget erősítő projektet tartalmaz, ami a készítők nyitottságát jelzi a szervezeti kereten kívüli együttmüködésre.

Mindhárom dokumentum fontos célja volt, a megbízó zöldfelületi és zöldhálózat fejlesztésekkel kapcsolatos elkötelezettségének, eddigi eredményeiknek és távlati céljainak demonstrálása. A készítés során mindhárom esetben, kimondva vagy kimondatlanul, de szempont volt a megbízó részéről az eredmények kommunikálása a választások során. A társadalmi egyeztetés alacsony intenzitása miatt a tervezési folyamat során ez a cél egyik esetben sem valósult meg igazán. Az elkészült dokumentációk minimális, internetes publikálása leginkább a dokumentumokat összeállító szakembereknek köszönhetően került sor. A dokumentum elfogadását követően az AngyalZÖLD stratégia esetében az eredmények kommunikációja intenzívebben valósult meg, a stratégiai és a Környezetgazdálkodási Kft. közös honlapján keresztül, valamint az önkormányzati sajtóközleményekben, kiadványokban.

A stratégiák módszertanában keverednek a pozitivista és a poszt-pozitivista elemek. A ProVerde! az, mely inkább a hagyományos koncepcionális tervezés eszközrendszerét használja, míg a Margitsziget stratégia az, mely inkább felvállalja a poszt-pozitivista tervezési módszertant. Erre legjobban a dokumentum a fejlesztéssel kapcsolatos ágazatok közötti konfliktusokat bemutató, valódi döntési alternatívákat megfogalmazó 2.9. fejezete mutat rá. Azonban a kutatási egység a 
poszt pozitivista fordulatra vonatkozó hipotézist akkor erősíthette volna igazán, ha a vizsgált stratégiák közül valamelyik a közösségi tervezés eszközeit alkalmazta volna a készítés során. Ez azonban egyik vizsgált stratégiáról sem állítható, mindegyikük az államigazgatási egyeztetésekben szokásos írásbeli megkeresés, valamint a folyamat végén tartott lakossági fórumok eszközeit használta. Ezek alapján a kutatás alapján azt jelenthető ki, hogy a vizsgált stratégiákban a posztpozitivista szemlélet megjelenése kimutatható.

Pro Verde! esetében nem volt világos, hogy melyik a stratégia megvalósításáért felelős szervezet. A dokumentumot a szakértő csapat meglehetős önállósággal készítette el. A Margitsziget Stratégia esetében a készítés során kristályosodott ki, hogy a készíttető zöldfelület fenntartó lehet a stratégiai megvalósításáért felelős ,gondnok”. A szervezet azonban csak kisebb mértékben, a SWOT analízisek készítésekor, illetve a dokumentum belső véleményezése során vett részt intenzívebben a kidolgozásban. Az AngyalZÖLD esetében a készítés megbízója és aktív résztvevője volt a zöldhálózat fejlesztéséért és fenntartásért felelős nonprofit szervezet, mely a dokumentumban foglaltak megvalósítását a stratégiaalkotást követően alapvető feladatának tekintette.

A megvalósulás számszerüsíthető eredményeit a 12. táblázat mutatja be. Ezek alapján a Pro Verde! az, amely javaslatai legkisebb mértékben, míg az AngyalZÖLD az, melynél a legnagyobb arányban vannak megvalósult valamint folyamatban lévő projektek. Egy településfejlesztési stratégiai annyira hatékony, amennyire a benne foglaltakat figyelembe veszik a fejlesztési/fenntartási döntéshozatalnál. A fentiek alapján a kutatási egység rámutat, hogy a településmegújítási stratégiák lehetnek az „íróasztal fiókjának készült”, a városigazgatási döntéshozatalra hatástalan dokumentumok. Hatékony eszközzé akkor válhatnak, ha van olyan szervezet, mely a stratégiában foglaltak megvalósítását, mely napi munkája során ezt feladatának tekinti, vagy ha egy stratégia egy adott szervezet feladatainak jobb ellátása céljából születik. Ez a dolgozat 4. hipotézisét erősíti meg. A települési szabadtérépítészeti stratégiák megvalósítási folyamatának, a benne résztvevő három fő szereplő (megbízó, tervező, lakosság) viszonyának bemutatása a kutatás tanulsága alapján segít abban, hogy a stratégiai megvalósításának eredményességét, vagy éppen eredménytelenségét megértsük. 


\subsection{Funkcióbővítő város-rehabilitációs projektek}

A harmadik kutatási egység a településmegújítás eszközeinek típusai közül az élénkítés és a kapacitásfejlesztés eszközeit hasznosító példákat vizsgál. A funkcióbővítő rehabilitációs pályázatok a településmegújítás folyamatait élénkítő eszközök tipikus példái. A pályázati kiírás egyik fontos célkitüzése volt, a nyertes önkormányzatoknál a települsmegújítási kapacitás rehabilitációs társaság létrehozásával való megerősítése.

\section{$\underline{\text { Az IVS-ek és az akcióterületi tervek }}$}

A vizsgált Integrált Városfejlesztési Stratégiák karakteresen eltérő módon közelítik meg az akcióterületek kijelölésének kérdését. Több önkormányzat (V., XVI.) több, jelentős kiterjedésü akcióterületet jelöl ki, melyek a kerület területeinek jelentős részét lefedik. A IV. kerületi önkormányzat ezzel szemben több, de kisebb, egy-egy konkrét helyszínre koncentráló akcióterületet jelöl ki. A VII. és a VIII. kerületi IVS-ek néhány, 2-4 db nagyobb kiterjedésű akcióterületet jelölnek ki. A Reprezentatív kaputérség kiépítése akcióterületi terv különlegessége, hogy az V. kerületi önkormányzat által kidolgozott akcióterületi terv a Fővárosi Önkormányzat pályázatának alátámasztó dokumentumául szolgál. Mivel az projekt három kerület területét is érinti (V., VI., VII.) a Belváros által készített dokumentum mindenképpen kérdéseket vet fel azzal kapcsolatban, hogy a projekt megalapozása során a beruházás lehetséges térszerkezeti szinergiái kellőképpen feltárásra kerületek-e.

A vizsgált akcióterület tervek között jelentős megközelítésbeli különbségek vannak. A Fővárosi Önkormányzat által készíttetett Reprezentatív kaputérségek dokumentum gyakorlatilag csak a pályázati mellékletként, a KMOP 5.5.2 pályázat keretében megvalósítani tervezett beruházásokat, és azok várható hatását mutatja be. A Sashalom városközpont rehabilitációs program időtávja ugyancsak a projekt lezárulásáig, 2010-ig terjed, és főként a pályázat keretében megvalósítandó beruházásokra koncentrál, megemlítve azért a kapcsolódó fejlesztéseket is. Újpest Főtér és környezetének fejlesztéseit bemutató dokumentum az akcióterület hosszú távú fejlesztésének dokumentuma, melynek a KMOP 5.5.2 pályázat keretében megvalósuló fejlesztések csupán egyik elemét jelentik a területen megvalósítandó fejlesztéseknek. A Kultúra utcája akcióterületi terv az akcióterület épületállományának igen részletes vizsgálata során javaslatokat fogalmaz meg valamennyi vizsgált tömbre. A 4. fejezet vázlatosan, akcióterületi részcélokként a rehabilitációs tevékenységek széles körét sorolja fel. Az akcióterület projekteket részletesen bemutató fejezet azonban már csak az KMOP 5.5.2 pályázat keretében megvalósítani tervezett projekteket mutatja be. A Józsefváros Palota-negyedének akcióterület terve a pályázat keretében és a pályázaton kívül 
megvalósítandó projekteket egyaránt tartalmaz. A pályázaton kívüli tevékenység az akcióterületet érintő, az önkormányzat által már korábban megkezdett, a terv készítésekor folyamatban lévő tevékenységeket tartalmazott.

Ezek alapján állítható, hogy az ATT-ben a EU pályázati projekt alátámasztó dokumentum és az IVS-t alátámasztó középtávú fejlesztési dokumentum szempontjai keverednek, és kerületenként eltérő mértékben hol az előbbi, hol az utóbbi tartalmi elemei jelennek meg hangsúlyosabbam. Mind a Városfejlesztési kézikönyv (VK 2009. : 64), mind a KMOP 5.5.2 pályázati kiírás (KMOP 2007: 17) az akcióterületi fejlesztések részletes pénzügyi tervének elkészítését is megköveteli, így elkerülhetetlen, hogy a rövidtávon és a középtávon megvalósítására kerülő projektek eltérő kidolgozottsággal kerüljenek a dokumentumba. Mivel a Városrehabilitációs kézikönyv ajánlása szerint az Akcióterület Tervek megvalósulásáról „a megvalósító szervezet évente beszámol az önkormányzatnak” (VK 2009: 59) így a fenti ellentmondás az ATT-k folyamatos aktualizálásával kiküszöbölhető.

\section{$\underline{\text { Az akcióterületi célok és elért eredmények összehasonlítása }}$}

A dolgozat, témájához illeszkedve az akcióterületi terveket abból a szempontból hasonlítja össze, hogy a pályázati kiírásban támogatható részcélként megjelölt tevékenységek közül vizsgált beruházások esetében az milyen arányban jelenik meg a közterületi szabadtér megújítás. A vizsgált öt rehabilitációs projekt szélsőségesen eltérő értékeket mutat a ebből a szempontból.

21. táblázat: A KMOP 2007. 5.5.2/B pályázatának vizsgált projektjeinek költségvetése és a közterületi - nem közterületi beruházások aránya (ATT-k alapján)

\begin{tabular}{|c|c|c|c|c|c|c|c|}
\hline \multirow[t]{2}{*}{ Pályázó } & \multirow[t]{2}{*}{ Projekt } & \multicolumn{2}{|c|}{$\begin{array}{c}\text { Projekt } \\
\text { költségvetés } \\
\text { bruttó mill. Ft. }\end{array}$} & \multicolumn{2}{|c|}{$\begin{array}{c}\text { Közterület- } \\
\text { építés ATT } \\
\text { szerin }\end{array}$} & \multicolumn{2}{|c|}{$\begin{array}{c}\text { Nem közterületi } \\
\text { építési elem } \\
\text { ATT szerint }\end{array}$} \\
\hline & & terv & $\begin{array}{c}\text { elfoga } \\
\text { dott }\end{array}$ & $\begin{array}{l}\text { nettó } \\
\text { mill. Ft }\end{array}$ & $\%$ & $\begin{array}{l}\text { nettó } \\
\text { mill. Ft }\end{array}$ & $\%$ \\
\hline $\begin{array}{l}\text { Fővárosi } \\
\text { önkorm. }\end{array}$ & $\begin{array}{l}\text { Budapest Szíve - } \\
\text { Reprezentatív kapu } \\
\text { térség }\end{array}$ & 3924 & 3268 & 3082 & 98 & 31 & 1 \\
\hline $\begin{array}{l}\text { Újpest } \\
\text { IV. ker. }\end{array}$ & $\begin{array}{c}\text { Nagyvárosi jövő - Új } \\
\text { Főtér }\end{array}$ & 1499 & 1027 & 600 & 50 & 343 & 29 \\
\hline $\begin{array}{l}\text { Erzsébet } \\
\text { város } \\
\text { VII. ker. }\end{array}$ & Kultúra utcája & 1156 & 1053 & 73 & 9 & 730 & 90 \\
\hline $\begin{array}{l}\text { Józsefváros } \\
\text { VIII. ker. }\end{array}$ & Palota negyed & 1666 & 1665 & 512 & 38 & 452 & 34 \\
\hline $\begin{array}{l}\text { Sashalom } \\
\text { XVI. ker. }\end{array}$ & $\begin{array}{l}\text { Sashalom városközpont } \\
\text { komplex rehabilitációja }\end{array}$ & 1173 & 1163 & 451 & 48 & 393 & 42 \\
\hline
\end{tabular}




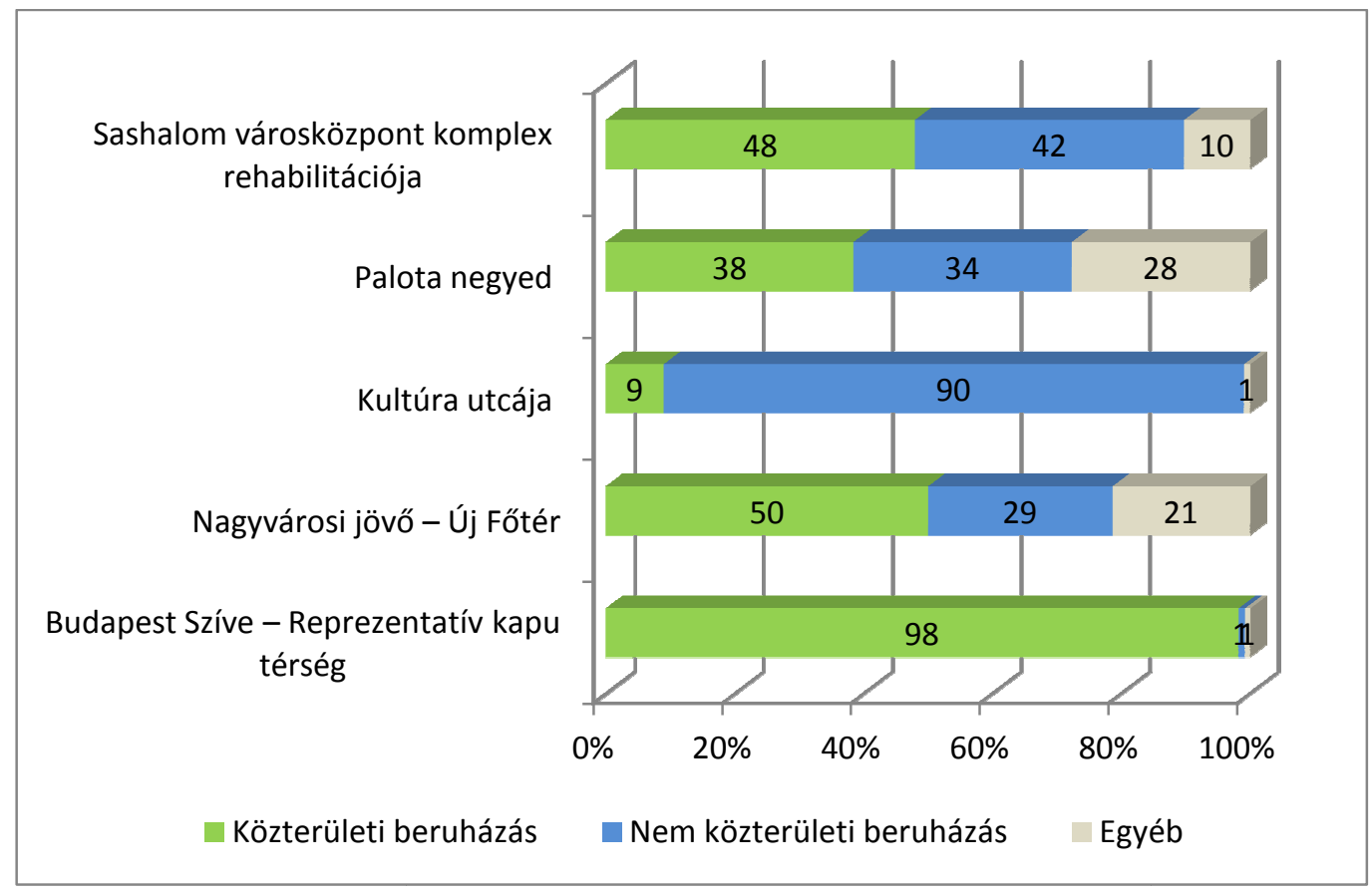

27. ábra: A közterületi és nem közterületi épített projektelemek költségének aránya (\%) a KMOP 2007 5.5.2/B pályázat keretében vizsgált öt projekt Akcióterület Tervében.

A Budapest Szíve - reprezentatív kaputérségek beruházás gyakorlatilag teljes egészében közterületi felújítási célokat valósít meg. Ezek között mind forgalomtechnikai rendezési tevékenységek, mind szabadtérépítészeti, gyalogos felület felújítási beruházási elemek szerepelnek. A közterületek minőségéhez kapcsolódnak a beruházás „szoft” elemei is, mint a falfirka mentesítés, illetve a parkosításhoz kapcsolódó lakossági akciók. Nem közterületi beruházási elemet egyedül a turinform iroda fejlesztése jelent.

A Kultúra utcája beruházás az előbbinek gyakorlatilag az inverze. Itt a beruházás döntő költséghányadát a kilenc épületet érintő ingatlanfejlesztések jelentik. Ezek között komplex, épület belsőt érintő fejlesztések mellett megjelennek a csak az épület homlokzatát érintő fejlesztések (Dob u. 29, Kazinczy u. 34 védett épületek esetében), melyek a közterületi, nem közterületi fejlesztések közötti határmezsgyét jelentik. A homlokzat felújítási projektelemek a költségvetés 19\%-át teszik ki. A projekt kimondottan közterületeket érintő fejlesztése a Kazinczy u. Dob u. - Wesselényi u. közötti szakaszának felújítása.

A Palotanegyed esetében ismét a közterületi fejlesztések szerepelnek nagyobb súllyal. Ennek keretében a díszvilágítási hálózat kialakítása jelentős hangsúllyal jelenik meg, amit a közterületi beruházások között szerepeltetek. Közterületi fejlesztés vázát az „egységes gyalogos - vegyes forgalmú közterületi rendszer, a korabeli hangulat felidézése, csak egyoldali parkolás kialakítása szerepel. Jelentős ingatlanfejlesztés valósult meg a Horánszky u. 13-ban létesülő InfoBox 
projektelem esetében. A Palotanegyed projektben ezen felül jelenős arányban jelenik meg a nem építési jellegű fejlesztések (Speciális piacok, Beadeker projekt).

A Nagyvárosi jövő - Új főtér esetében a közterületi felújítások jelentős túlsúlya figyelhető meg. Ezek között a Szent István tér, illetve a Mándy Lajos utca felújítása szerepel. A beruházás három épülethomlokzat felújítási eleme (Szt. István tér 23, Mándy Lajos u. 2, István út 12.) ugyancsak a közterületi arculat megújításához kapcsolódó beruházás. Szintén jelentős összegeket fordít a fejlesztés ingatlan felújításra, mely keretében a Városháza korszerüsítése, illetve az ehhez kapcsolódó Rathauskeller projektrész megvalósítása szerepel. Ez utóbbi a városháza pince területén alakított ki szolgáltatási teret. Az üzletutca program ugyancsak ingatlanfejlesztési elemeket tartalmaz.

A sashalmi városközpont komplex rehabilitációja projekt keretében ismét a legnagyobb beruházási tétel a közterületekkel kapcsolatos fejlesztések csomagja volt. A Havashalom park kialakítása, a sashalmi piactér és sétány kialakítása, a Veres Péter, Vörösmajor és Margit utcák egyes szakaszainak felújítása, kivilágítás és térfigyelő rendszer kiépítése a beruházási költségek 48\%-át tették ki. A beruházás másik jelentős tételét az ingatlan-beruházások alkották, melyek között a sportcsarnok, ökopiac és szolgáltatóház kialakítása jelent meg.

A fenti összevetések alapján megállapítható, hogy a vizsgált öt beruházás közül négy a projektek megvalósítási költségeinek legjelentősebb részét közterületek megújítását célzó, vagy - a homlokzat megújítások esetén - azokhoz szorosan kapcsolódó fejlesztésekre fordította. Tehát a KMOP 2007. 5.5.2/B pályázati kiírás célja közül a vizsgált pályázatok döntő többségében a szabadterek rehabilitációját kezelte prioritásként, ezzel igazolva a dolgozat 5. hipotézisét.

A pályázati dokumentációban kitüzött célok megvalósulásával kapcsolatban érzékelhető, hogy a 2008-tól kibontakozó gazdasági válság és ingatlanpiaci recesszió nem hagyta érintetlenül azokat a projekteket, melyek ingatlanpiaci partner közremüködésére számítottak. Ez leginkább tetten érhető a Kultúra utcája projektben volt, ahol az Elektrotechnikai Múzeum hátsó épületének vendéglátási célú felújítását végezték volna külső beruházó közreműködésével. A beruházó a megvalósítás során, finanszírozási indokból azonban visszalépett, és így az épület felújítás csak jelentős csúszással, csökkentett tartalommal és önkormányzati többlet források segítségével 2013-ban fejeződött be. Újpesti pályázat esetében A Szt. István tér 23., és az István út 12. épületek homlokzatfelújításai maradtak el, a társasházak visszalépésének következtében, illetve a Rathauskeller vendéglátási célú hasznosítására nem került sor mind a mai napig. Ez utóbbinál a gazdasági recesszió mellett a kivitelezési minőség is jelentős hátráltató tényező. A Budapest Szíve - 
Kaputérségek pályázat esetében a pályázati elemek maradéktalanul megvalósultak, azonban az IVSben jelzett csatlakozó, részben piaci alapú fejlesztések (Városháza Fórum, mélygarázs építés) nem valósultak meg. A Palotanegyed beruházás kapcsán a Horánszky utcában létesült InfoBox és Vállalkozói Központ beindítása is a tervezettnél lassabban halad. A pályázat kapcsán maradéktalanul a Sashalom Városközpont valósult meg, mely teljes mértékben önkormányzati területeket és ingatlanokat érintett, külső gazdasági finanszírozásra nem támaszkodó elemeket tartalmazott. A projektben szereplő gazdasági elem (sashalmi piac felújítása) pedig olyan a területen korábban is meglévő szolgáltatási funkció fejlesztését célozta, melyet a gazdasági válság hatásai nem befolyásoltak kedvezőtlenül.

\section{A projektek megvalósításának szervezeti kerete}

A kutatásban vizsgált öt funkcióbővítő rehabilitációs projekt közül négynél a pályázatai elöírások hatására alakították meg a városrehabilitációs tevékenységgel foglalkozó társaságot. Míg korábban egyedül a józsefvárosi Rév8 Zrt. volt ilyen funkciót betöltő cég, a projekt révén valamennyi vizsgált önkormányzatnál létrejött. A pályázat kiíróinak azon szándéka, hogy a kiírás segítse elö, hogy a városrehabilitációs folyamatokat komplex módon kezelni tudó, önkormányzattól független településmenedzsment szervezetek valósítsák meg a projekteket, első ránézésre úgy tűnhet, teljesült.

A sashalmi önkormányzat esetében azonban kizárólag a pályázati elvárások miatt létrehozott XVI. kerületi Városfejlesztő Kft. sosem müködött. A nevében megjelölt feladatot, a projekt megvalósítását az önkormányzat polgármesteri hivatalának szervezeti egységeiből és külső szakértőkből álló, a polgármester által felügyelt team végezte. A XVI. kerülettől eltekintve, a többi önkormányzat esetében a városfejlesztő, fejlesztési és beruházási, rehabilitációs és városfejlesztési megnevezésűt társaságok koordinálták a beruházások megvalósítását. Az interjúkban elhangzottak alapján, a társaságok hatékonyabb, rugalmasabb és gyorsabb müködésre voltak képesek ebben az önálló szervezeti formában, mint ha az önkormányzat szervezeti egységei végezték volna a feladatot. Azt is több megkérdezett jelezte, hogy az önkormányzati tulajdonú, de ami ennél is fontosabb az önkormányzat müködését jól ismerő, a polgármesteri hivatalban személyes munkakapcsolatokkal is rendelkező menedzsment sikeresebben töltötte be az önkormányzattal való kapcsolattartást, mintha azt egy független külső menedzsment cég tette volna. Ennek alapján állítom, hogy a pályázati kiírás projektmenedzsmentre vonatkozó elvárásai - a XVI. kerülettől eltekintve - nagyban segítették a vizsgált projektek megvalósulását. Ez igazolja a 4. hipotézis településmegújítási programok megvalósítására vonatkozó részét. 
A vizsgált projektszervezetek közül a Rév8 kivételével valamennyi az önkormányzat szervezeti egységeivel szoros kooperációban végezte a projektek előkészítését és megvalósítását. Az együttmüködésnek a legtipikusabb formái heti rendszerességü kooperációs egyeztetések voltak (IV., VI., XVI. kerületek esetében). A Rév8 a projektek előkészítését majd megvalósítását nagyobb önállósággal végezte, annak ellenére, hogy a formális döntési kompetenciák itt is az önkormányzat kezében voltak. Budapest Szíve projekt esetében a projekt koordináció céljából egy teljesen újszerü szervezett került felállításra. A Projekt Irányító Bizottság néven működő szervezet a fővárosi és az V. kerületi önkormányzat képviselőiből, az érintett fővárosi ügyosztályokból, valamint a projekt menedzsment szervezetből állt össze. A szervezet lehetőséget biztosított, hogy a kétszintű fővárosi önkormányzatiságból adódó, a főváros és a kerületek közötti nehézkes kommunikáció a projekt megvalósítás kapcsán gördülékenyebbé váljon.

A projekt-menedzsment szervezetek sikeres müködései ellenére az interjúk során az is kiderült, hogy az öt társaságból már csak kettő tölti be funkcióját. A XVI. kerületi Városfejlesztő Kft., mely a projekt megvalósulása alatt piacfelügyeleti feladatokat látott el, a projekt megvalósítását követően felszámolásra került. Újpest és Erzsébetváros esetében a létrehozott városfejlesztő társaságok jelentős szerepet töltöttek be a projekt megvalósításában, a Főtér Kft. esetében elsősorban a kivitelezési munkák koordinálást, Erzsébetváros Kft. esetén komplex projektmenedzsmenti feladatokat ellátva. A projektek lezárulását követően egyik cég sem kapott új feladatott, az előbbi megszünt, az utóbbi műszaki ellenőri feladatokat lát el. Budapest Szíve Városfejlesztő NKft. jelenleg is végzi a fővárosi önkormányzat közterületi rehabilitációs pályázatai megvalósításának koordinálást. A projektek előkészítése azonban nem ebben a társaságban, hanem a tulajdonos BKKban történik. A Rév8 esetében is jelentős feladatcsökkenés figyelhető meg. A megvalósítás kereteinek vizsgálata arra is rámutatott, hogy a projekt megvalósításával kapcsolatos döntési kompetenciát a vizsgált projektek többségénél (Sashalom, Kultúra utcája, Újpest városközpont) a megvalósítással kapcsolatos operatív döntéshozó fórumokat az önkormányzat politikai vezetői (polgármesteri, alpolgármesteri) szinten tartotta meg. A Budapest Szíve Kaputérségek projekt esetében a döntéshozó testület szerepét betöltő PIB a kerületi és a fővárosi önkormányzat delegált képviselöiből állt. Csupán a Palotanegyed projekt volt az, ahol az operatív döntéshozói szint a RÉV8 szervezetében, politikai döntéshozóktól nagyobb függetlenséggel működött. Az eredmények megcáfolták a kutatás 6. hipotézisét.

A kutatás még egy érdekes folyamatot enged sejteni. Az újpesti beruházást koordináló Főtér Kft. a beruházás befejezését követően átalakult Újpesti Városgondnokság Szolgáltató Kft. (Újpest Kft.) névre. A feladata a fötér közterületi üzemeltetése valamint a kerületi tulajdonú zöldterületek, 
játszóterek fenntartása és fejlesztése, környezetgazdálkodási feladatok ellátása lett. ${ }^{44}$ Józsefváros esetében az ingatlan fejlesztések menedzselését a korábban csak üzemletetést végző Kisfalu Kft. veszi át, míg a közterületi fejlesztések koordinálását a Városfejlesztési és Főépítészi Iroda ${ }^{45}$. Hasonló konstrukció alakult ki Erzsébetvárosban is, ahol a korábban ingatlan üzemeltető feladatokat ellátó ERVA Zrt. ${ }^{46}$ a polgármesteri hivatal Városgazdálkodási Irodájával együttmüködve menedzseli az újabb fejlesztési beruházásokat. Ezek a folyamatok azt jelzik, hogy az önkormányzatok a fejlesztési feladatokat az üzemeltetési feladatok alá rendelve, vagy legalábbis szerezeti szempontból a fenntartási feladatokat végző cégekbe integrálva tervezik végezni az elkövetkezendőkben. Ezzel párhuzamosan a projektek megvalósításával kapcsolatos feladatokat részben a polgármesteri hivatal osztályaival osztják meg.

A lakossággal való partnerség kérdését illetően a Palotanegyed beruházás volt az, ahol kétirányú kommunikáció és széles körü együttmüködés kialakult. A Civilek a Palotanegyedért egyesület aktív szervező-résztvevője volt a projekt előkészítésének, és a beruházó lehetőséget teremtett számukra a megvalósulás pontos nyomon követésére is. A Kaputérség projekt kapcsán a projekt menedzsment intenzív, több csatornás tájékoztatási tevékenységet végzet. Ezek jelentős mértékben túlmutattak a projektről szóló tájékoztatás feladatán, a társasházaknak szervezett társasház menedzsmenti kurzus, az érintett vállalkozásoknak tartott online marketing tréning mind a kapacitásfejlesztő beavatkozások közé sorolhatók. Az újpesti fötér esetében a parkolóhelyek csökkentése az, amely kapcsán a legintenzívebb kommunikáció folyt. Itt a piacot használó üzlettulajdonosok korábbi díjmentes parkolási lehetőségének megszüntetése helyett, az érintettekkel való egyeztetés alapján egy kisebb területen kereskedői parkoló kialakítása lett a kompromisszumos megoldás. A Kultúra utcája projektben a területen szanálásra kerülő lakások tulajdonosaival folytattak érdemi egyeztetéseket. A Sashalmi projekt kapcsán a hangsúly főként az érintettek tájékoztatásán volt. A fentiek azt jelzik, hogy a valódi - kétirányú kommunikációt tartalmazó - társadalmi részvétel alapvetően nem jellemezte a megújítási projekteket, az eredmények nem igazolják a 1. hipotézist. Azonban a Palota negyed révén megjelenik példa a poszt-pozitivista tervezési módszertanra.

\footnotetext{
${ }^{44} \mathrm{http}: / /$ varosgondnoksag.ujpest.hu/

${ }^{45} \mathrm{http}: / /$ www.kisfalu.hu/

${ }^{46} \mathrm{http}: / /$ www.ervainfo.hu/
} 


\section{Tézisek}

\begin{tabular}{|l|l|}
\hline 1. hipotézis & $\begin{array}{l}\text { Az hazai urbanisztikai gondolkodás paradigmaváltó korszakba érkezett. A korábbi } \\
\text { pozitivista személet helyett a poszt pozitivista megközelítés válik általánossá a XXI. század } \\
\text { elsö évtizedének végétöl. }\end{array}$ \\
\hline 1. tézis & $\begin{array}{l}\text { Az poszt-pozitivista paradigmaváltás igazolása. } \\
\text { Megállapítottam, hogy a hazai urbanisztikai gondolkodás paradigmaváltó korszaka } \\
\text { eloótt áll. A korábbi pozitivista személet mellett a poszt-pozitivista megközelítésü } \\
\text { tervezési metodikák is megjelennek a XXI. század első évtizedének végétől. }\end{array}$ \\
\hline
\end{tabular}

A kutatásom nem erősítette meg, hogy a magyarországi urbanisztikai gondolkodás paradigmaváltó korszakba érkezett. A kvalitatív interjúk során társadalmi részvétel fontossága többször is felmerült, mint fontos a település megújítást segítő tényező, valamint a társadalmi konszenzus megteremtését a válaszadók jellemzően a fontos eszközök közé sorolták. Azonban a konszenzusteremtés poszt-pozitivista eszközeit illetően a társadalmi részvétellel, a lakosság bevonásával kapcsolatban fenntartások is megfogalmazódtak. Az érintettek közönye, konszenzus kialakításának nehézsége volt az, amit a leginkább gyakori akadályként elhangzott. Tervezői részről volt a közösségi részvételt elutasító vélemény is, arra hivatkozva, hogy „,az orvos sem kérdi meg a pácienstöl, hogy hogyan mütse”.

Igazoltam, hogy a vizsgált stratégiai dokumentumokban különböző mértékben, de megjelenik a posztpozitivista módszertan. A tervek készítése során a poszt pozitivista tervezési attitűd dominanciáját jelző társadalmi bevonásra csak formálisan került sor. A képet azonban árnyalja, hogy a dokumentumokban megfogalmazott - egyes esetekben már megvalósult - projektek között viszont több társadalmi bevonáson, partnerségen alapuló projekt található.

A harmadik kutatási egységben vizsgált funkcióbővítő rehabilitációs projektek között nem találtam jellemzőnek az érintettek valódi bevonására tett lépéseket. Azonban itt is megállapítottam hogy, a Palotanegyed beruházásában, a Civilek a Palotanegyedért Egyesület partnerként való bevonásával a tervezés és megvalósítás folyamatában, megjelent az első fecske a társadalmi részvétellel történő projekt megvalósítás terén.

\begin{tabular}{|l|l|}
\hline 2. hipotézis & A településfejlesztési stratégiák a településfejlesztés kulcsfontosságú eszközei. \\
\hline 2. tézis & $\begin{array}{l}\text { A településfejlesztési stratégiák jelentőségének igazolása. } \\
\text { Vizsgálataimmal megállapítottam, hogy a településfejlesztési stratégiák az átalakuló } \\
\text { városi területek megújításának legjelentősebb, kulcsfontosságú eszközei. }\end{array}$ \\
\hline
\end{tabular}

A 15 urbanisztikai beavatkozás típust felsoroló kvantitatív felmérésem eredménye szerint a települési jövőképek, stratégiák az átalakuló városi területek megújításának leghatékonyabb eszközei. A második 
leghatékonyabb beavatkozás a megújítást koordináló szervezet létrehozatala volt a kutatási eredmények szerint. míg a közterületek megújítása a negyedik helyet foglalta el relatív rangsorban.

A kutatásom azonban arra is rámutatott, hogy egy „stratégia” megnevezésű dokumentum önmagában nem segíti a településmegújítási folyamatokat. A kvalitatív interjúim során jelezték az interjúalanyok, hogy az IVS-eket az önkormányzatok több esetben nem valódi rendeltetésük szerint, hanem mint pályázati támogatások megszerzéséhez szükséges kötelezően elkészítendő dokumentumot kezelik. A dolgozat második kutatási egységében vizsgáltam, hogy a településfejlesztési szabadtérfejlesztési stratégiai dokumentumokban kitüzött célok ennyiben valósultak meg. Ezekben ugyancsak jelentős eltéréseket találtam. Ennek okait a 3. tézis foglalja össze.

\section{3. hipotézis $\quad$ A városi szabadterek megújitási projektek a városmegújítások fontos katalizáló elemei.}

A kutatásom nem erősítette meg és nem is cáfolta egyértelmúen, hogy a városi szabadterek megújítási projektek a városmegújítások fontos katalizáló elemei. Az interjúim során többen jelezték, hogy a forgalomcsillapítással kapcsolatos beavatkozások illetve közparki fejlesztések azok melyek jellemzően felértékelnek egy adott városi területrészt, azonban azt is jelezték, hogy ezek hatása nem feltétlen direkt és sokszor nehezen mérhető.

Vizsgálatomban megállapítottam, hogy a Közép-Magyarországi Operatív Program (KMOP) 2007. 5.5.2/B „Funkcióbővitö rehabilitáció, Budapesti integrált városfejlesztési program, Budapesti kerületi központok fejlesztés" projektek esetében több pályázati dokumentum is jelezi, hogy a közterületek felújítását jelentős arányba tartalmazó beruházások célja a térség megújulásának katalizálása, a fejlesztő hatások továbbgyürüzése (Budapest Szíve, Újpest főtér, Kultúra utcája). Megállapítottam, hogy a projektek eredményei egyelöre ezt nem erősítik meg ezeket a célokat. Olyannyira nem, hogy több projekt esetében a projekt keretében tervezett magán fejlesztők bevonására épülő projektelemek meghiúsultak. Az okot a vizsgálataimban megkérdezettek egyértelmüen a 2008-tól kibontakozó gazdasági válságban látják, mely legmélyebben éppen az ingatlanpiacot érintette. A projektek befektetést vonzó hatására a Budapest Szíve Kaputérség, illetve a Kultúra Utcája program esetén jeleztek kisebb, meglévő kereskedelmi egységek megújulását tartalmazó eredményeket.

Megállapítottam, hogy éppen a 2008-ban induló recesszió elnyúló hatása miatt, a kutatási eredmények a tézis cáfolására, antitézis megfogalmazására sem adnak lehetőséget. A jelentős mértékben lelassuló ingatlanfejlesztési környezet nem ad módot, hogy a dolgozat írásakor 1-2 éve megvalósult projekteket ebből a szempontból, egyéb fővárosi helyszínekkel összevetve értékeljem.

\begin{tabular}{|l|l|}
\hline 4. hipotézis & $\begin{array}{l}\text { A településfejlesztési szabadtérépitészeti stratégiák céljainak megvalósitása akkor lehet } \\
\text { hatékony, ha létezik vagy létrejön a megvalósításáért felelös operatív szervezet. }\end{array}$
\end{tabular}




\begin{tabular}{|l|l|}
\hline \multirow{3}{*}{ 3. tézis } & $\begin{array}{l}\text { A megvalósító szervezetek jelentőségének meghatározása. } \\
\text { Megállapítottam, hogy településfejlesztési stratégiák, illetve komplex } \\
\text { településmegújítási programok esetén a megvalósításért felelös operatív szervezet } \\
\text { jelenti a garanciát a megfogalmazott célkitúzések megvalósítására. Eredményeimmel } \\
\text { rámutattam, hogy a stratégiát megfogalmazó dokumentumnak ennek az operatív } \\
\text { szervezettnek az adottságait, eszköz és érték rendszerét figyelembe véve kell készülnie. }\end{array}$ \\
\hline
\end{tabular}

A szabadtérfejlesztési stratégiákat vizsgáló kutatási egység eredményeivel alátámasztottam, hogy egy stratégiai dokumentumban megfogalmazott, átfogó programok megvalósítás akkor lehet hatékony, ha van olyan operatív szervezet, mely a stratégia lépésről-lépésre történő megvalósítását, ütemezetten megvalósításra kerülő projektekre bontását feladatának tekinti. Vizsgálataimmal rámutattam, hogy a szabadtérépítészeti stratégiák közül az AngyalZÖLD esetében a XIII. kerületi zöldhálózat fenntartását és fejlesztését végzö XIII. Kerületi Környezetgazdálkodási KNKft. a dokumentum készítésében szorosan együttműködött a dokumentumot összeállító szakértővel. A Margitsziget Stratégia esetében a Főkert Zrt a Margitsziget fenntartását végző munkatársai a dokumentum SWOT analízisének elkészítésében müködtek közre. A főpolgármesteri hivatal számára készített ProVerde! esetében szakértő csoport nagy önállósággal dolgozva, a megvalósítás szervezeti keretére figyelmet nem fordítva határozta meg a dokuntum tartalmát. A dokumentumokban foglaltak megvalósulását illetően a sikerességi sorrend is ennek megfelelően alakult.

Szintén alátámasztottam tézisemet a kvalitatív interjúkkal, melyek során több alany részéről megfogalmazott javaslatok melyek - más más formában ugyan, de - egyöntetủen a főváros városmegújítását koordináló stratégiai tervezö és menedzsment szervezet megvalósítását javasolták.

Megállapítottam, hogy a KMOP projektek esetében a XVI. kerület kivételével a többi önkormányzat esetében városfejlesztő, fejlesztési és beruházási, rehabilitációs és városfejlesztési megnevezésűt társaságok koordinálták a komplex beruházások megvalósítását. Az interjúkban elhangzottak alapján igazoltam, hogy a társaságok hatékonyabb, rugalmasabb és gyorsabb müködésre voltak képesek ebben az önálló szervezeti formában, mint ha az önkormányzat szervezeti egységei végezték volna a feladatot. A XVI. kerület estében az polgármesteri hivatal szervezetén belül jött létre a projekt megvalósító operatív szervezet.

\begin{tabular}{|l|l|}
\hline 5. hipotézis & $\begin{array}{l}\text { A fövárosi átalakuló területekhez kapcsolódó kerületközpont rehabilitációs pályázatokon } \\
\text { döntő súllyal jelent meg a szabadtér rehabilitáció. }\end{array}$ \\
\hline 4. tézis & $\begin{array}{l}\text { A szabadtér rehabilitáció jelentőségének igazolása. } \\
\text { Megállapítottam, hogy kutatásban vizsgált fővárosi átalakuló területekhez kapcsolódó } \\
\text { kerületközpont rehabilitációs pályázatok többségében döntő súllyal jelent meg a } \\
\text { szabadtér rehabilitáció. }\end{array}$ \\
\hline
\end{tabular}


KMOP 2007. 5.5.2/B pályázati kiírás lehetőséget nyújtott mind az épületekhez kapcsolódó (épület felújítás, bővítés, létesítés, örökségvédelem) mind a szabadtereket érintő (közterület rendezés, örökségvédelem, közlekedés szervezés) építési tevékenységek megvalósítására (KMOP 5.5.2/B pályázati kiírás: 10). Vizsgálataimmal igazoltam, hogy a harmadik kutatási egységben vizsgált öt beruházás közül négy a projektek megvalósítási költségeinek legjelentősebb részét közterületek megújítását célzó, fejlesztésekre fordította. Csupán az erzsébetvárosi „Kultúra utcája” projekt volt az, ahol az épületek felújításához kapcsolódó projektelemek voltak túlsúlyban. Ezek alapján megállapítottam, hogy a vizsgált funkcióbővítő rehabilitációs pályázati projektek többségében az önkormányzatok a szabadterek rehabilitációját prioritásként kezelték.

\begin{tabular}{|l|l|}
\hline 6. hipotézis & $\begin{array}{l}\text { A KMOP funkcióbövítő pályázatok révén - a kiíró szándékával összhangban - az integrált } \\
\text { városmenedzsment új szervezeti eszköze jött létre az érintett önkormányzatoknál. }\end{array}$ \\
\hline 5. tézis & $\begin{array}{l}\text { Integrált városmenedzsment szervezet kialakítás kudarcának kimutatása. } \\
\text { Megállapítottam, hogy a KMOP funkcióbővítő rehabilitációs pályázatok - a kiíró } \\
\text { szándékával ellentétben - nem hozták létre az integrált városmenedzsment új, az } \\
\text { polgármesteri hivataltól elkülönült szervezeti eszközét az érintett önkormányzatoknál. }\end{array}$ \\
\hline
\end{tabular}

Kutatási eredményemmel igazoltam, hogy pályázati kírással nem lehet önkormányzati szervezetfejlesztést végezni. Megállapítottam, hogy a dolgozatban vizsgált, a KMOP 2007 5.5.2/B pályázatánál követelményként szereplő városfejlesztési társaságokat a projektek kapcsán létrehozták az önkormányzatok. A vizsgált projekt közül csak négy esetében végezték valójában ezek a szervezetek a projekt menedzsmenti faladatokat. Megállapítottam azt is, hogy a projekt megvalósítását követően három kerületnél a társaságot felszámolták. A megmaradó két társaság esetében is a beruházás megvalósítását követően már csak szüken értelmezett projektmenedzsmenti feladatokat látnak el és nem funkcionálnak komplex településmegújítási szervezetként. A projekt megvalósításának szervezeti kereteit vizsgálva egyöntetűen látszott az az önkormányzati törekvés, hogy az operatív döntéshozatali szint felett ellenőrzést gyakoroljon a politikai vezetői szint. Egyedül a RÉV8 esetében mondható el, hogy a projekt menedzsment operatív döntéshozatala a szervezeten belüli, szakmai szinten valósult meg. A pályázatoknál jól megfigyelhető volt a követlen önkormányzati kontrol kiterjesztése is a beruházások lebonyolítására.

A vizsgálataimmal igazoltam, hogy a pályázati funkcióbővítő beruházások megvalósítását követően az önkormányzatok többsége a beruházási feladatok egy részét önkormányzati tulajdonú, korábban üzemeltetési feladatokat végző társaságokba integrálta. Az újpesti beruházást koordináló Főtér Kft. a beruházás befejezését követően átalakult Újpesti Városgondnokság Szolgáltató Kft. (Újpest Kft.) névre. A feladata a főtér közterületi üzemeltetése valamint a kerületi tulajdonú zöldterületek, játszóterek fenntartása és fejlesztése, környezetgazdálkodási feladatok ellátása lett. Józsefváros esetében az ingatlan fejlesztések menedzselését a korábban csak üzemletetést végző Kisfalu Kft. veszi át, míg a közterületi fejlesztések 
koordinálását a Városfejlesztési és Főépítészi Iroda végzi ${ }^{47}$. Megállapítottam, hogy hasonló konstrukció alakult ki Erzsébetvárosban is, ahol a korábban ingatlan üzemeltető feladatokat ellátó ERVA Zrt. ${ }^{48}$ a polgármesteri hivatal Városgazdálkodási Irodájával együttmüködve menedzseli az újabb fejlesztési beruházásokat. Sashalom esetében pedig továbbra is a polgármesteri hivatal osztályaiból és irodáiból összeálló projekt teamek koordinálják teljes körúen az önkormányzati beruházásokat.

\begin{tabular}{|c|l|}
\hline \multirow{2}{*}{ 6. tézis } & $\begin{array}{l}\text { A szakmai csoportok közötti karakteres véleménykülönbségek kimutatása. } \\
\text { Igazoltam, hogy a felmérésben megkérdezett szakemberek szakmai csoportjai } \\
\text { vizsgálva karakteres eltérés figyelhető meg annak tekintetében, hogy mely beavatkozás } \\
\text { típust tartják inkább hatékonynak. Megállapítottam, hogy ezeknek az eltérő } \\
\text { megközelítéseknek az ismerete alapot jelent a szakmai csoportok közötti hatékonyabb } \\
\text { együttmüködés, az, „új városi szövetség” irányába }\end{array}$ \\
\hline
\end{tabular}

A dolgozat bevezetőjében nevesített Toledói Dekrétumban szereplő célkitüzés az „új városi szövetség életre hívása", a városmegújítási folyamatok számos szereplőjének bevonásával. A kutatás eredményeivel rávilágítottam, hogy a településmegújítás eszköztárának megítélésében milyen egyezések és milyen különbségek vannak a „szövetség” lehetséges szereplői között. Összefoglalóan megállapítottam, hogy önkormányzati és állami beavatkozások alakítás/szabályozás/élénkítés/kapacitásfejlesztés terminológiájának bontásában az alakítást, majd a kapacitás-fejlesztést tartják leghatékonyabbnak a kormányzati tisztviselők, az önkormányzati főépítészek és a településrendezők. Az alakítást, majd az élénkítést tartják leghatékonyabbak az önkormányzati tárasság vezetők és a szabadtértervezők. Az élénkítést majd az alakítást tartják leghatékonyabbak az ingatlanfejlesztők. A kvalitatív interjúkkal részletesebben rávilágítottamanak az érintett csoportok közötti véleményeltérésekre és véleményazonosságokra is. Ez kiindulási alapot jelenthet a vizsgált szakmai csoportok közötti együttmüködés, ,,szövetség” irányába.

\footnotetext{
${ }^{47}$ http://www.kisfalu.hu/

${ }^{48} \mathrm{http}: / /$ www.ervainfo.hu/
} 
22. táblázat: Az egyes beavatkozás típusok jelentőségének értékei a megkérdezett szakmai csoportok szerint

\begin{tabular}{|c|c|c|c|c|c|c|}
\hline & \multicolumn{6}{|c|}{ Megkérdezett szakmai csoport } \\
\hline $\begin{array}{c}\text { Beavatkozás } \\
\text { típus }\end{array}$ & $\begin{array}{c}\text { Kormányzati } \\
\text { tisztviselők }\end{array}$ & $\begin{array}{l}\text { Önkorm. } \\
\text { föépítészek }\end{array}$ & $\begin{array}{c}\text { Önkorm. } \\
\text { fejlesztési } \\
\text { társaság vezetői }\end{array}$ & $\begin{array}{l}\text { Szabadtér- } \\
\text { tervezők }\end{array}$ & $\begin{array}{l}\text { Település- } \\
\text { rendezők }\end{array}$ & $\begin{array}{l}\text { Ingatlan- } \\
\text { fejlesztők }\end{array}$ \\
\hline $\begin{array}{c}\text { Fejlesztési } \\
\text { környezet } \\
\text { alakítása }\end{array}$ & 3,00 & 2,75 & 3,00 & 3,20 & 3,40 & 1,75 \\
\hline $\begin{array}{c}\text { Fejlesztési } \\
\text { környezet } \\
\text { szabályozása }\end{array}$ & 0,89 & 1,33 & 0,83 & 1,20 & 0,73 & $-0,17$ \\
\hline $\begin{array}{l}\text { Fejlesztési } \\
\text { környezet } \\
\text { élénkítése }\end{array}$ & 1,74 & 1,03 & 2,33 & 2,19 & 1,52 & 1,91 \\
\hline $\begin{array}{l}\text { Kapacitás } \\
\text { fejlesztés }\end{array}$ & 2,00 & 2,50 & 1,50 & 1,50 & 2,00 & 1,63 \\
\hline
\end{tabular}

\begin{tabular}{|l|l}
\hline \multirow{7}{*}{ 7. tézis } & $\begin{array}{l}\text { Az hazai urbanisztika eszköztárának módosítása az átalakuló városi területek } \\
\text { megújítása érdekében. }\end{array}$ \\
\hline $\begin{array}{l}\text { Megállapítottam, hogy az átalakuló városi területek megújításához, a } \\
\text { településfejlesztés hazai eszköztára módosításra szorul. Rámutattam, hogy a } \\
\text { szabályozás eszközeiről (településrendezési tervezés) a hangsúlyt az alakítás eszközeire } \\
\text { (stratégiai tervezés és menedzsment) szükséges áthelyezni. }\end{array}$
\end{tabular}

Az átalakuló városi területek megújítását vizsgáló kvantitatív felmérésem egyértelmúen jelezte, hogy a megkérdezett interjúalanyok a négy beavatkozási típus közül az alakítás eszközeit tartják a leghatékonyabbnak, míg a szabályozás eszközeit a legkevésbé hatékonynak. A szabályozási tervek eszközét a megkérdezett szakértői csoportok közül éppen a településrendezési tervkészítéssel foglalkozó tervezők ítélték a legkevésbé hatékonynak. Ugyancsak megállapítottam, hogy a megkérdezettek nem az élénkítés eszközeit (állami, önkormányzati beruházások, pályázati támogatások) ítélték az átalakuló városi területek megújításának leghatékonyabb eszközének.

A kvalitatív interjúim során a szakemberek számos lehetséges eszközét vázolták fel az alakítás eszközeinek fejlesztésére. Ugyanakkor a településrendezés, jelenleg nem kellően hatékony eszközeinek megújítására is több javaslatot fogalmaztam meg. megfogalmazásra. Ezeket a következő fejezet részletezi. 


\section{Javaslatok}

A XIX. Országos Hild János Urbanisztikai Konferencia a „változás és alkalmazkodás az urbanisztikában” alcímet viselte. A konferencia Városi Paradigma Változása szekciójának bevezető előadásában hangzott el, hogy korábbi növekedés megszünésével, a külső források beszükülésével, a társadalmi szerkezet változásával szembenézve, az urbanisztikának új eszközöket kell keresnie a kihívások megválaszolásához. (Kuslits 2013: 7). A kutatási eredményeimmel megerösítettem a külső források szükülésének tényét. A dolgozat első kutatási egységében, a kvalitatív interjúk összefoglalójaként 54 beavatkozás típust tartalmazó eszköz listát határoztam meg az interjúalanyok által az átalakuló városi területek megújításában hasznosnak ítélt beavatkozásokról. A kutatásom alapján javasolt eszközök teljes listáját a 11. táblázatban közlöm. A táblázatban szereplő eszközökre vonatkozó javaslatokat a 2. számú mellékletében a kvalitatív interjúkat összefoglalói részben mutatom be. Az itt felsorolt urbanisztika eszközök, jelen kutatás fókuszánál lényegesen tágabb - vélhetően így sem teljes - tárát mutatják be, hasznos adatokkal szolgálva további kutatások számára. Fontos eredményem hogy az átalakuló városi területek megújítása kapcsán az alakítás eszközeit kell hatékonyabban alkalmazni, részben kapacitásfejlesztés eszközeinek segítségével. Ezek közül két javaslatot emelek ki. Az egyik a 100000 lakos nagyságú közigazgatási egységekre (ez a nagyobb lélekszámú fővárosi kerületek lakosság számának nagyságrendje ${ }^{49}$ ) kialakítandó üzemeltetési és fejlesztési társaságok kialakítása. A másik pedig a főváros egészével foglalkozó „,agytrösztöt”, jelentős kutatási, koncepcióalkotási és projekt menedzselési kapacitással rendelkező tervező/menedzsment iroda létrehozatala.

A kutatásommal igazoltam, hogy az átalakuló városi területek megújításának a szabályozás (településrendezési tervezés) a legkevésbé hatékony eszköze. Hangsúlyozni szeretném, hogy ez távolról sem jelenti azt, hogy ez az eszköz fölösleges. Azt viszont megítélésem szerint igen, hogy ez az eszköz is megérett a megújításra. A megújítás egyik lehetséges módja - a kvalitatív interjúk során elhangozott javaslatok alapján - a szabályozási tervek kiegészítése ingatlanfejlesztési tanulmánytervvel. Ez a tanulmányterv ingatlanfejlesztési szempontból (telekár, beruházási költség, a létrehozott ingatlan piaci értéke) igazolhatná, hogy a szabályozási tervben megfogalmazott paraméterek gazdasági szempontból is racionálisak. Az ilyen, az önkormányzat által kidolgozásra kerülő ingatlanfejlesztési tanulmányterv biztosíthatná, hogy a - jelenlegi gyakorlatban sokszor a beruházó által finanszírozott - településrendezi tervekben megfogalmazásra kerülő szabályozási paraméterek beruházási költség/haszon vonzatainak ismeretében hozhassa meg az önkormányzat döntését a szabályozás elfogadásáról/elutasításáról, határozhassa meg a településrendezési szerződés tartalmát. A szabályozás eszköztárának megújítására további lehetőséget ad a közterület-alakítási terv 2012-ben bevezetett új eszköze ${ }^{50}$.

\footnotetext{
${ }^{49}$ Budapest kerületei közül a KSH 2010-es adatai szerint a III., IV., XI., XIII., kerületek népessége haladta meg a 100000 föt. Az I., V., VI., XXII. kerületek népessége pedgi nem érte el ez 50000 föt.

${ }^{50}$ A 314/2012.(XI.8.) Korm. rendelet a településfejlesztési koncepcióról, az integrált településfejlesztési stratégiáról és a településrendezési eszközökről $27 \S$ bevezette a közterület-alakítási terv fogalmát, melynek részletes tartalmi követelményei is meghatározásra kerületek a rendelet mellékeltében. A közterlület-alakítási tervkészítés nem kötelezö, hanem lehetséges eszköze az önkormányzatoknak.
} 
A szabadtérépítészeti stratégiákat vizsgáló fejezetemben megállapítottam, hogy komplex és közép-hosszú távú stratégiák megvalósítása akkor lehet hatékony, ha van a megvalósításért felelős operatív szervezet. A kutatásommal ugyanakkor arra is rámutattam, hogy pályázati kiírással nem lehet hatékonyan szervezetet fejleszteni. Ennek analógiájára állítom, hogy jogszabályalkotással sem. Ebből az következik, hogy a hatékony települési stratégia alkotás kiindulópontja a megvalósításáért felelös szervezet szerkezetének, céljainak, kapacitásának feltérképezése kell, hogy legyen. És nem a 6.2-ik, ahogy ez a 314/2012-es kormányrendelet 2. számú mellékletében szerepel.

A KMOP 2007. 5.5.2/B funkcióbővítő rehabilitációs projektek vizsgálatával megállapítottam, hogy az EU finanszírozású településmegújítási beruházások kapcsán rengeteg urbanisztikai tapasztalat halmozódott fel a projekteket megvalósító szervezeteknél. ${ }^{51}$ Rámutattam, hogy a projektek tapasztalatait kritikai módon összefoglaló tanulmányt a közremüködő Pro-Régió szervezet nem készített. ${ }^{52}$ Megítélésem szerint további urbanisztikai kutatásoknak fontos terepe lehet a projektek sikereinek, kudarcainak és eredményeinek független szakmai elemzése.

A dolgozatom egyik legfontosabb eredménye és üzenete az, hogy a komplex településfejlesztési programok és projektek vizsgálatához, a sikerek megismétléséhez, a kudarcok elkerüléséhez nem elég a fizikai környezet változását elemezni. Szükség van a megvalósítás folyamatának, a megvalósítás szervezeti struktúrájának megismerésére, a szereplők kapcsolat-, érdek- és értékrendszerének vizsgálatára. A dolgozatommal igazoltam, hogy ehhez az intézményi urbanisztikai kutatási módszerek jól hasznosítható eszközt nyújtanak.

A dolgozatomban a Toledói Dekrétum szellemében, az átalakuló városi területek megújításának tárházát differenciáltan, az abban résztvevő urbanisztikai szereplők csoportjait vizsgálva elemeztem. Ennek keretében négy csoportot különítettem el; kormányzati tisztviselők, önkormányzati fóépítészek, önkormányzati fejlesztési társaság vezetők, szabadtér tervezők, településrendező tervezők, ingatlanfejlesztők. Ahhoz, hogy a Toledói Dekrétum szellemében létrejöhessen egy szövetség a fenti szereplök között, megállapítottam, hogy fontos megismerni a csoportok érték- és érdekrendszerét, mert csak így található meg az a platform, amely mentén egy ilyen szövetség felállhat. A kutatás ennek a kérdéskörnek csak a felszínét érinti. Hasznos volna, egy egy konkrét beavatkozásra koncentrálva vizsgálni az érintettek közötti vélemény különbségeket és vélemény azonosságokat, meghatározva a közös érdekek menti lehetséges együttműködéseket. A korábban említett településrendezési tanulmányterv tartalmának meghatározása lehetne az együttmúködés próbaterepe. A kutatás rámutatott továbbá, hogy a fenti szereplőkön túlmenően még egy nagyon fontos érintett csoportra kell kiterjeszteni a vizsgálatokat. Mégpedig az önkormányzati politikai döntéshozókra, akik a kutatás tanulsága szerint a települési urbanisztikai folyamatok kapcsán egészen az operatív döntéshozatali szintig élni kívánnak befolyásukkal.

\footnotetext{
${ }^{51}$ Koszorú Lajos véleménye a 2. számú mellékletében.

52 2012. aug. 13-i e-mail váltásom alapján állítom ezt a Pro-Régió intézkedésfelelős csoportvezetővel.
} 


\section{6. Összefoglalás}

A dolgozat Budapest példáján keresztül vizsgálja a városi területek megújításának eszköztárát. A kutatás az átalakuló városi területekre fókuszál, hiszen Budapest esetében (is) ezek jelentős településfejlesztési kihívást és egyúttal lehetőséget jelentenek. A doktori iskola profiljához igazodóan kiemelt hangsúllyal vizsgálom a szabadterekkel kapcsolatos beavatkozásokat, közöttük is a szabadtérépítészeti stratégiákat és az önkormányzati közterület megújítási projekteket.

A szakirodalmi áttekintés során a dolgozat 1.1. fejezetében definiálja az „átalakuló települési területek" fogalmát, értve alatta azokat a korábban már építéssel érintett területeket, melyek eredeti funkciójukat már nem, vagy csak részben töltik be és átalakításuk, megújításuk a településfejlesztés vérkeringésébe való bekapcsolásuk állami/önkormányzati beavatkozást igényel. Az 1.2. fejezet az urbanisztikai folyamatok intézményi elemzésének módszereit tekinti át, ezzel készítve elő a kutatási rész vizsgálatait. Az 1.3. fejezet a településfejlesztési eszközök rendszerezését végzi el, részletesen bemutatva David Adams által kidolgozott, alakítás/szabályozás/élénkítés/kapacitás fejlesztés féle kategóriákat tartalmazó rendszert. A dolgozat kutatási rézében ezt a csoportosítási tipológiát alkalmazom. Az 1.4. fejezet a stratégia tervezés módszerén keresztül mutatja meg, hogy mit jelent a poszt-pozitivista megközelítés a településfejlesztésben. Az 1.5. fejezetben két külföldi esettanulmány kerül bemutatásra. A szabadtér rehabilitáció jelentősége kapcsán ikonikussá vált „Barcelona modell” a térségi fejlesztési stratégiákra épülő közterület megújítási projektek miatt releváns a kutatás számára. A londoni olimpia rehabilitációs beruházás pedig volumene, illetve frissessége mellett azért fontos, mivel arra példa, hogy egy barnamező megújítási projekt hangsúlya - átmeneti intenzív hasznosítást követően - hogyan tolódhat el a szabadtér megújítás, a zöldhálózati fejlesztés irányába.

\section{I kutatási egység: A városi területek megújításának eszköztára.}

Az első kutatási egység a fővárosi urbanisztika folyamatokat jól ismerő, elismert szakemberekkel készítetett interjúk alapján állítja relatív rangsorba az átalakuló városi területek megújításának eszközeit. Az interjúk kvantitatív felméréseinek elemzése mutatja, hogy szakemberek az állami/önkormányzati beavatkozások közül - David Adams kategóriáit alkalmazva - összességében az alakítás, majd ezt követően a kapacitásfejlesztés eszközeit tartják a leghatékonyabbnak az átalakuló városi területek megújításában. Arra is rámutat azonban a kutatás, hogy az egyes szakértői csoportok (államigazgatási munkatársak, önkormányzati föépítészek, településfejlesztési társaság 
vezetők, szabadtérépítészek, településrendezők, ingatlanfejlesztők) véleménye között karakteresek az eltérések. A csoportok véleménye azonban megegyezett abban, hogy a szabályozás eszközei a legkevésbé hatékonyak a területek megújítása segítésére. Összességében az állami/önkormányzati beavatkozások eredményességében leginkább a településfejlesztési társaságvezetők és a szabadtértervezők bíznak, míg a leginkább szkeptikus csoportot, az ingatlanfejlesztőket is túlszárnyalva a települési föépítészek alkotják.

A kvantitatív interjúk lehetőséget nyújtottak arra, hogy kvantitatív felmérés kérdéseiröl részletesebb és árnyaltabb vélemények kerüljenek megformálásra, részletezve az erősen eltérő vélemények okait, jelezve a szakmai csoportok közötti konszenzus kialakításának lehetőségeit. Az interjúalanyok a településmegújítás eszközeire vonatkozóan 54 beavatkozási típusra adtak javaslatot megjelenítve ezek között az alakítás/szabályozás/ élénkítés/kapacitásfelesítés tárházának széles skáláját.

\section{II kutatási egység: Fövárosi szabadtérmegújitási stratégiák}

Az első kutatási egység egyik fontos konklúziója, hogy az átalakuló városi területek megújításának a fejlesztési stratégiai a leghatékonyabb eszközei. A második kutatási egysége a három szabadtérépítészeti stratégia (ProVerde!, Margitsziget Stratégia, AngyalZÖLD) készítésének folyamatát és az elért eredményeiket vizsgálja. A vizsgált stratégiák közül a Margitsziget Stratégia az, mely a poszt pozitivista módszertant legmarkánsabban használja, míg a Pro Verde! módszereiben még inkább a fejlesztési koncepció készítés pozitivista módszerei dominálnak. A dokumentumokban megfogalmazott projektek megvalósításának arányát vizsgálva az AngyalZÖLD stratégia tünik a leginkább sikeresnek. Ennek oka az, hogy tervet készíttető a kerület zöldhálózat fenntartásáért és fejlesztéséért felelős XIII. Kerületi Környezetgazdálkodási Kft. végig aktív résztvevője volt a dokumentum kidolgozásának, majd a stratégia önkormányzati elfogadását követően a dokumentumban foglaltak megvalósítása a társaság feladatává vált.

\section{III kutatási egység: Funkcióbövítö rehabilitációs projektek}

A harmadik kutatási egység a településmegújítás eszközeinek típusai közül az élénkítés és a kapacitásfejlesztés eszközeit hasznosító példákat vizsgál. A KMOP 2007-es funkcióbővítő településrehabilitációs pályázat öt támogatást nyert projektjének elemzése során igazolásra kerül, hogy a vizsgált projektek közül négy esetében a szabadtérmegújítási projektelemek alkották a beruházások jelentősebb hányadát. Ez alól az erzsébetvárosi Kultúra utcája projekt jelent kivételt, ahol a beruházás legnagyobb részben az akcióterületi épületek felújítására koncentrált. 
A kutatási egység a projektek megvalósításának szervezeti kereteinek elemzéséhez ismét a kvalitatív interjúk módszerét használja megállapítva, hogy a vizsgált projektek mindegyikénél a projekt megvalósítása egyedi szervezeti struktúrában történt. Ezeknek a struktúrának minden esetben része volt településmegújítási társaság, melyet több esetben a pályázati kiírás elvárásai miatt hoztak létre az önkormányzatok. A társaságok projekttel kapcsolatos feladatai igen különbözőek voltak a vizsgált öt esetben, azonban egyik esetben sem váltak a kerületek településmegújítást tervező és koordináló szervezeteivé. A beruházásokkal kapcsolatos operatív döntéshozatal három projekt esetében is az érintett szervezeti egységek bevonásával, alpolgármesteri/polgármesteri irányítással tartott „kooperációs értekezletek” voltak. A projektek lezárultát követően a településfejlesztési társaságot három esetben felszámolták, míg a Rév8 és Budapest Szíve Kft. estében feladataikat szüken értelmezett pályázatmenedzsmentre szükítették.

Az kutatási eredmények alapján az átalakuló városi területek megújítására vonatkozó javaslatok az alakítás és a kapacitásfejlesztés eszközeink alkalmazására vonatkozó ajánlásokat tartalmaznak. A kutatási fontos eredménye, hogy rámutat, hogy az intézményi urbanisztikai elemzési módszerek a tervezési folyamatok illetve a településmegújítási projektek elemzésének, összehasonlíthatóvá tételének hasznos eszközei. 


\section{Summary}

Through the example of Budapest the paper examines the tool kit of regenerating urban areas. The subjects of the research are the transitional areas within the city, since in the case of Budapest (as well) these locations form significant challenges but also opportunities for development. Due to the profile of the doctoral school I focus on interventions concerning open spaces such as the open space development strategies and public space regeneration projects of the municipalities.

In the chapter 1.1. the paper defines the 'transitional urban areas' as previously developed areas which don't or only partially serve their original functions, and which regeneration requires state or municipal intervention. Chapter 1.2. presents the institutional approaches of analysing urban transformations. The later research chapters use this institutional approach. Chapter 1.3. presents the typologies of urban regeneration tools. The typology of David Adams which divides the state intervention into categories of shaping, regulating, stimulating and capacity building is described in greater details, since this is the typology which is used by the first research unit. Through the methods of strategic planning chapter 1.4. presents the post positivist approach toward urban planning. In chapter 1.5. tow case studies are presented. The first is the iconic 'Bareclona modell' where open space regeneration projects were supported by the initial regional strategic planning process. The second example is the London 2012 Olympic regeneration project which is relevant for the research because it presents how the focus of a brown field regeneration might be shifted after a temporary intensive land use towards open space regeneration and green network development.

\section{$1^{\text {st }}$ research unit: The tool kit of regeneration transitional urban areas}

The first research unit makes a ranking list of the tools of regenerating transitional urban areas. The quantitative analysis has been created by interviewing experts with extensive knowledge of the urban planning processes in Budapest, the legal and economic background of urban regeneration. The quantitative analyses shows, that in the opinion of the interviewees in general the tools of shaping are regarded as the most effective followed by the capacity building tools. The research also drew attention on the fact that there are characteristic differences between the different groups of professionals (governmental officials, municipal chief architects, managers of urban development companies, urban planners, open space designers and real estate developers). However the different professionals seemed to agree that the tools of regulating are the least effective to achieve 
regeneration in transitional urban areas. It was the managers of regeneration companies and the open space designers who trusted in the potential effectiveness of intervention the most, while the most sceptic group was the municipal chief architects who were even more sceptical than the real estate developers.

The quantitative interviews made it possible to form a more detailed and subtle opinion about the questions of the quantitative interview. This gave an opportunity to describe the reasons why some opinions were very polarised on certain subjects and also to indicate how it would be possible to reach some sort of consensus between the professional groups. The interviewees named 54 types of possible interventions in how to regenerate transitional urban areas, presenting a wide range of tools of forming/regulating/stimulating/capacity building.

\section{$2^{\text {nd }}$ research unit: Open space regeneration strategies in Budapest}

One of the main conclusions of the first research unit is that the most helpful tools of regenerating transitional urban areas are the development strategies. The second research unit analyses the process of strategy forming and the achievements of three open space regenerations strategic plans (Pro Verde Budapest, Margit Island Strategy, AngelGREEN 13 ${ }^{\text {th }}$ distrirct's Green Network Strategy). Among these the Margit Island Strategy was the one which was most coherent in using the post positivistic planning methods, while in the case of the Pro Verde still the positivistic planning approach dominates. If we compare how many programs and projects were realised of the recommendations of the documents, it is the AngelGREEEN strategy which seems to be the most successful. The reason of this is that the company responsible for the management and development of the green spaces of the district, was involved in the planning process from the beginning till the end, and after the strategy was officially accepted by the district council the realisation of the programs and projects listed in the document became it's responsibility.

\section{$3^{\text {rd }}$ research unit: Function enhancement rehabilitation projects}

Analysing the tool of regeneration of urban areas further, the third research unit examines examples of stimulating and capacity building. The study examines five function enhancement rehabilitation projects funded by 2007. Central Hungary Operative Program. One conclusion of the research is that in four cases the major part of the projects was the regeneration of open spaces. The only exemption was the 'Street of Culture' project where the major part of the project budget was spent on the renewal of buildings. 
Using the qualitative interviews again the next part of the unit analyses the organisational pattern how the projects were realised, concluding that each project created a unique organisational structure. An urban regeneration company, in more cases created as a prerequisite of the governmental funding, was part of these structures in all instances. These companies had very different role in the project realisation in the five case studies, however they have not become the districts main organisation responsible for the planning and coordination of urban regeneration. In three cases the platform of the operative decision making was a 'cooperation meeting' chaired by the major or vice major. Following the completion of the projects three of the regeneration companies were liquidated while in the case of the $8^{\text {th }}$ and the $5^{\text {th }}$ districts the task of the companies was narrowed down to administrative management of further projects.

The conclusion part of the research includes recommendations how the tools of shaping and the capacity building can be utilised to help the regeneration of transitional urban areas. One significant conclusion of the research is that the methods of institutional urbanism are useful tools to analyse and compare planning processes and urban regeneration project. 


\section{Irodalomjegyzék}

\section{Elsődleges irodalmi források}

1. Czike Gábor dr (2010): Memorandum, subject: Településrendezési szerződés, Ormai és Társai, CMS Cameron McKenna LLP, Budapest

2. English Partnership (2003): Towards a national brownfield strategy, Research Findings for The Deputy Prime Minister,

3. Lipcsei Kartaa fenntartható európai városokról, A német Európa Tanács Elnökség összefoglalója az Informális Településfejlesztési és Területi Kohéziós Miniszteri találkozóról, 2007. május 24. Lipcse

4. MÉK Táj- és Kertépítészeti Tagozat, Magyar Kertépítészek és Tájrendezők Szövetsége (2011): Szakmai céljaink (indoklással és javaslatokkal), Az OTÉK módosításával kapcsolatban, http://www.tagszem.hu/files.php

5. Toldedo Informal Ministerial Meeting on Urban Development Declaration, Spanish Presidency, Toledo 22 June 2010

\section{Barcelona modell, London Olimpia 2012}

6. Associacio Pla Estrategic Barcelona 2000 (1998): Barcelona 2000. Butlletõ ' de l'Associacio’ Pla Estrategic Barcelona 2000, No. 6, Barcelona.

7. Bullivant, Lucy (2007): London's 2012 Olimpics Stadium Planned, Architectural Record http://archrecord.construction.com/news/daily/archives/071206london.asp

8. BBC (2008): Will 2012 deliver promised jobs boost? Tuesday 26 August 2008 13:39 UKHouse of Commons (2008): The budget for the London 2012 Olympic and Paralympic Games, Committee of Public Accounts, http://www.publications.parliament.uk/pa/cm200708/cmselect/cmpubacc/85/85.pdf

9. Department for Culture, Media and Sport - DCMS (2011): London 2012 Olympic and Paralympic Games, Annual report February 2011., culture.gov.uk/publications/7800.aspx

10. Glancey, Jonathan (2011): The ArcelorMittal Orbit has faced planty of criticism- but it's a grower, The Gardian, Friday 28 October 2011

11. Hervey, Lia; Chennaoui, Orla (2012): Sky Investigation: Olympics Bills ops 12bn GBP http://news.sky.com/home/london-olympics/article/16156780

12. Houes of Commons: The budget for the London 2012 Olympic and Paralympic games, Forteenth Report of Session, 2008:8 
13. London Development Agency - LDA (2008): Legacy Now - the beginning of the Legacy Masterplan Framework, Continuing the dialogues to create a fantastic Olympic legay afther the 2012 Games,

http://tblp.localknowledge.co.uk/Assets/3244/legacy_launch_event_summary_report\%283\% 29\%5B1\%5D.pdf

14. London Development Agency - LDA (2010): Thames Gateway Parklands: Delivering Envrionmental Transformation, Greening the Gateway Partnership http://www.lda.gov.uk/publications-and-media/publications/thames-gateway-parklands.aspx

15. London Legacy Development Corporation - LLDC (2012): Stitcching the Fringe: Working around the Olimpic Park

16. Olympic Delivery Authority - ODA (2006): Map referred to in the Olympic Delivery Authority (Planning Functions) Order 9th August 2006

17. Olympic Delivery Authority - ODA (2006b): The Olympic Park Masterpaln, Building venues and dreams for the next generation,

18. Olympic Delivery Authority - ODA London Development Agency - LDA (2007):

Commitment to sustainable regeneration, Olympic, Paralympic \& Legacy transformation planning applications for the olympic park, February 2007.

19. Olympic Delivery Authority - ODA (2007b): An Inspiring Legacy a Great Future Afther a Great Games, 2007. ref: LOV/24/7 http://www.london2012.com/documents/odaplanning/planning-applications/design-principles-for-the-olympic-park.pdf

20. : Olympic Delivery Authority - ODA (2008):Change, Investing in the furure, ref: ODA 2008/88 http://www.london2012.com/documents/oda-publications/oda-legacy.pdf

21. Pricewaterhouse Coopers (2005): Olympic Games Impact Study, Final report, Department of Culture, Media and Sport

22. Sokol, David (2010): London Zooming toward 2012 Summer Olympics, Architectureal Record

http://archrecord.construction.com/news/daily/archives/2010/100222london_olympics.asp

\section{Szabadtérmegújítási stratégiák}

23. Pro Verde! Budapest zöldfelületi rendszerének fejlesztési koncepciója és programja, 2006. Budapest Főváros Önkormányzat, Környezetvédelmi Ügyosztály, Studio Metropolitana Kht.

24. Margitsziget Stratégiai Terve egyeztetési dokumentáció. BFFH Környezetvédelmi Ügyosztály, Főkert Zrt. 2008. október

25. A Margitsziget Fejlesztési Terve, Munkaközi példány, 2013. május 
26. AngyalZÖLD - Zöldfelületi Stratégia 13, a XIII. Kerületi Önkormányzat zöldfelület fejlesztési stratégiája és zöldhálózat fejlesztési programterve, 2008 június, XIII. kerületi Környezetgazdálkodási KNkft

27. AngyalZÖLD, A XIII. Kerületi Önkormányzat zöldhálózati stratégiája, beszámoló a megvalósítás eddigi eredményeiről, 2010 július XIII. kerületi Környezetgazdálkodási KNkft

28. AngyalZÖLD Stratégia felülvizsgálat 2011-2014 - Budapest XIII. kerületi Önkormányzat zöldhálózat fejlesztési programterve 2011 június XIII. kerületi Környezetgazdálkodási KNkft

\section{ÚMFT KMOP 5.5.2 pályázat}

29. Nemzeti Fejlesztési és Gazdasági Minisztérium (2009): Városfejlesztési Kézikönyv, Területfejlesztésért és Építésügyért Felelős Szakállamtitkárság, Második javított kiadás

30. Pályázati Útmutató a Közép-Magyarországi Operatív Program „Funkcióbővítő rehabilitáció” Budapesti integrált városfejlesztési program - Budapesti kerületi központok fejlesztése (KMOP-2007-5.2../B), Új Magyarország Fejelsztési Terv, EU, ERFA

31. Budapest Városrehabilitációs Programjának felülvizsgálata és javaslat a Program továbbfejlesztésére (2006), Egyeztetési dokumentációs, Ecorys Magyarország Kft., Láposi Roland projektmenedzser, BFFH megbízó

32. Budapest Főváros Integrált Városfejlesztési Stratégia (2008?), Stúdió Metropolitana Kht., Kovács Bence projekt menedzser (Euroconsult $2000 \mathrm{Kft}$ ).

33. Belváros - Lipótváros Integrált Városfejlesztési Stratégiája (2010), Város-Teampannon Kft, Szántó Katalin vezető tervező,

34. Budapest Szíve Program - Reprezentatív Kaputréség kiépítése I. ütem (2009), Módosításokkal egységes szerkezetbe foglalt Akcióterületi terv, KMOP 2007-2008-as akcióterv kiemelt projekt, HitesyBartuczHollai (HBH) Euroconsulting Kft.,

35. Újpest Integrált Városfejlesztési Stratégia (2008), Város-Teampannon Kft, Koszorú Lajos, Szántó Katalin vezető tervezők

36. Újpest, Főtér és környéke Akcióterület terv (2008), Érték Térkép Kft, Varga Ötvös Béla ügyvezető igazgató

37. Integrált Városfejlesztési Stratégia Budapest, VII. kerület Erzsébetváros fejlesztésére (2008),Városfejlesztés Kft.,

38. Budapest, VII. kerület Erzsébetváros funkcióbővítő rehabilitációja végleges akcióterület terv „Kultúra utcája” (2009), Városfejlesztés Kft.

39. Budapest - Józsefváros Integrált Városfejlesztési Stratégia 1-4 kötet, (2008), Rév8 Józsefvárosi Rehabilitációs és Városfejlesztési Zrt,, Alföldi György , Sárkány Csilla, dr. Juharos Róbert, Ifj. Erdősi Sándor 
40. Budapest Európa Belvárosa (2009), Kulturális-gazdaság Fejlesztési Program, Józsefváros Palotanegyed, Akcióterületi Terv, Rév8 Józsefvárosi Rehabilitációs és Városfejlesztési Zrt,, Alföldi György, Sárkány Csilla, dr. Juharos Róbert

41. Budapest XVI. kerület integrált városfejlesztési stratégiája 2008-2013 (2008), Carpatihia Zrt - TeTT Consulting Kft.

42. Sashalom városközpont komplex rehabilitációja (2009), A projekfejlesztéis szakaszban a Pro Régió Kht igényeinek megfelelően módosított változat, Econorg Hungary Kft.

43. Budapest Városrehabilitációs Programjának felülvizsgálata és javaslatok a program továbbfejlesztésére (2005), Egyeztetési dokumentáció Ecorys Magyarország Consulting, porjektmenedzser Láposi Roland,

44. Gábor Péter, Pap Félix, Répássy Gergely (2007): Ingatlanberuházások Budapesten és Pest megyében 2006-ban és 2007-ben, E-Build Információs és Tanácsadó Kft.

\section{Másodlagos irodalmi források}

1. Adams D., Allmendinger P., Dunse N., Houston D., Tiesdell S., Townend J., Turok I., White M. (2003): Assessing the impact of planning, housing, transport and regeneration policies on land pricing, Report to the ODPM, Universities of Aberdeen and Glasgow,

2. Adams D., Watkins C., White M. (2005): Examining Public Policy and Propoerty Markets in Planning, Public Policy and Property Markets, Blackwell, Oxford pp 17-36. DOI: http://dx.doi.org/10.1002/9780470757789

3. Allmendinger, Philip (2002): The Post-Positivist Landscape of Planning Theory in Planning Futures, new directions for planning theory ed. Allmendinger, Philip; TewdwrJones, Mar, Routledge, London

4. Allmendinger, Philip (2002a): Towards a post-positivist typology of planning theory, in Planning Theory, Vol 1, pp 77-99. DOI: http://dx.doi.org/10.1177/147309520200100105

5. Allison, Michael; Kaye, Jude (2005): Strategic Planning for Nonprofit Organizations: A Practical Guide and Workbook, Second Edition, John Wiley \& Sons, New Jersey

6. Alker S., Joy V., Roperts P., Smith N. (2000): The definition of Brownfield, Journal of Environmental Planning and Management, 43(1), pp. 49-69. DOI: http://dx.doi.org/10.1080/09640560010766

7. Alexander E.R. (2001): Why planning versus markets is an oxymoron: asking the right question, Planning and Markets http://www-pam.usc.edu/volume4/v4ila2print.html

8. Amin A. (2003): The Economic Base of Contermporary Cities In: Bridges G., Watson S. (eds): A Companion to the City, Blacwell Oxford, 
9. Ball M. (1998): Institutions in British property research: A review, Urban Studies 35 (9), pp. 1501-1517. DOI: $\underline{\text { http://dx.doi.org/10.1080/0042098984259 }}$

10. Barker, Kate (2004): Review of Housing Supply: Delivering Stabiltiy, Securing our Future Housing Needs, Final Report- Recommmendations, HM Treasury, Norwich

11. Barta Györgyi szerk. (2004): A budapesti barnaövezet megújulási esélyei, MTA Társadalomkutató Központ

12. Bartha, Gabó (2008): The Struggle for Hunyadi Square: Residents vs. Budapest Sixth District City Hall, Local Governance Brief, Open Society Institute, Budapest vol. 9 no. 1,

13. Benach, Nuria (2004): Public Spaces in Barcelona 1980-2000 in Marshall, T. (ed.): Transforming Barcelona, Routledge, London

14. Borja, J., Castells, M. (1997): Local and Global, London, Earthscan

15. Bryman, Alan (2004): Kvantitatív és kvalitatív módszerek összekapcsolása in Letenyei László (szerk.) (2004): Településkutatás Szöveggyüjtemény L Harmattan - Ráció Kiadó, Budapest

16. Bryson, John M. (2004): Strategic Planning for Public and Nonprofit Organizations: A Guide to Stratngthening and Sustaining Organizational Achievements, 3rd Edition, Jossey-Bass, San Francisco

17. Chadwick, Geroge (1971): A Systems View of Planning, Oxford, Pergamon

18. Creighton, James L (2005):The public participation handbook, Jossey-Bass, San Francisco

19. Csanádi Gábor, Csizmady Adrienne, Kocsis János Balázs, Kőszeghy Lea, Tomay Kyra (2010): Város, Tervező, Társadalom, Sík kiadó Budapest

20. Dale, Reidar (2004): Development Planning: Concepts and Tools for Planners, Managers and Facilitators, Zed Books Ltd., London

21. Dixton, Timothy (2007): The Property Development Industry and Sustainable Urban Brownfield Regeneration in England: An Anlalysis of Case Studies in Thames Gateway and Greater Manchester, Urban Studies Vol. 44, pp 2379-2400. DOI: http://dx.doi.org/10.1080/00420980701540887

22. Dömötör Tamás (2008): Közösségi Részvétel a területi tervezésben, BCE Tájépítészeti és Döntéstámogató Rendszerek Doktori Iskola, PhD dolgozat. http://phd.lib.uni-corvinus.hu/338/

23. Esteban, Juli (2004): The planning project: bringing value to the periphery, in Marshall, Tim (ed.): Transforming Barcelona, Routlege London

24. Faragó Kálmán (1986): Városrekonstrukció: a magyar városok korszerűsítése, Tankönyvkiadó, Budapest 1986

25. Fung, Archon; Wright, Erik (2001): Deepening Democracy: Innovations in Empowered 
Particpatory Governance, Politics \& Society, Vol. 29. No. 1. March 2001, pp: 5-41.

DOI: http://dx.doi.org/10.1177/0032329201029001002

26. Gábor Péter (2010): Zöldterületek minőségértékelése Budapest XIII. kerületében, 4D Tájépítészeti és kertmüvészeti folyóirat, Vol 18. pp 20-33

27. Gehl, Jan (2001): Life Between Buildings: Using Public Space, The Danish Architectural Press, Arco Grafiks,

28. Gore T., Nicholson D. (1991): Models of the land development process, a critical review, Environment and Planning A 23, pp. 705-730. DOI: http://dx.doi.org/10.1068/a230705

29. Hall, Peter (1996): Cities of Tomorrow, An Intelectulal History of Urban Planning and Design in the Twentieth Cenutruy, Blackwell, Oxford

30. Hall, Peter (1998): Cities in Civilization: Culture, Innovation and Urban Order, Phoenix Giant, London

31. Harris, Neil (2002): Collaborative Planning: From Thoeoretical Fundations to Practice Forms in Planning Futures: new directions for planning theory ed. Allmendinger, Philip; Tewdwr-Jones, Mar, Routledge, London

32. Healey P. (1992): An institutional model of the development process, Journal of Property Research, 9 pp. 33-44. DOI: http://dx.doi.org/10.1080/09599919208724049

33. Hodgson, G. M. (1997): Economics and Evolution : Bringing Life Back into Economics (second ed.) Polity Press Cambridge

34. Hodgson, G. M. (1999): Economics and Utopia, Routledge, London

35. Jámbor Imre (2012): Bevezető - Az élhető települési táj 2., workshop megnyitója in Élhető Települési Táj, Tudományos Közlemények és értekezések, 4D Könyvek BCE,

36. Karadimitriou, Nikos (2007): Re-use of Previously Developed Land: Housbuilder Adaptation to a Changing Context, University College London, Bartlett School of Planning, $\mathrm{PhD}$ Thesis

37. Karlócainé Bakay Eszter (2012): Lakótelepek szabadtérépítészete 1945-1990 között Budapest példáján, BCE Tájépíészeti Kar, Tájépítészeti és Tájökológiai Doktori Iskola, PhD dolgozat http://phd.lib.uni-corvinus.hu/605/

38. Koszorú Lajos (2004): Térszerkezet és barnaövezet in Barta Györgyi szerk.: A budapesti barnaövezet megújulási esélyei, MTA Társadalomkutató Központ

39. Kuslits Tibor (2013): A városi paradigma változása in Miből élünk jövőre? változás és alkalmazkodás az urbanisztikában, XIX. Országos Hild János Urbanszitikai Konferencia, p. 7.

40. Locsmándi Gábor (1999): A településrendezés szabályozásának kérdéséhez: részletek egy nagyobb tanulmányból in Urbanisztika 2000, Szerk. Csontos János - Lukovich Tamás, Akadémiai kiadó. 
41. Lukovich Tamás (2001): A posztmodern kor városépítészetének kihívásai, második, javított, bővített kiadás, Pallas Stúdió

42. Marshall Tim (2000): Urban Planning and Governance: Is there a Barcelona Model?, International Planning Studies, Vol.5, No.3, pp 299-319. DOI: http://dx.doi.org/10.1080/713672855

43. Meggyesi Tamás (2005): A 20. század urbanisztikájának útvesztői, Terc Budapest

44. Mihály Éva (2010): Win-win, avagy a srófadó, http://podo-pro.hu/win-win-avagy-asrofado/

45. Mintzberg, Henry (1994): The Fall and Rise of Strategic Planning, Harvard Business Review, Harvard Business School Publishing, Boston MA, pp. 107-114

46. Monclús, Frencisco-Javier (2003): The Barcelona model: an original formula? From 'reconstruction' to strategic urban projects, Planning Perspectives Vol. 18. pp. 399-421. DOI: http://dx.doi.org/10.1080/0266543032000117514

47. M Szilágyi Kinga (2012): Az ,élhető települési táj” zöldfelületi, ökológiai, térségi és társadalmi összefüggései in Élhető Települési táj Tudományos közlemények és értekezések, 4D könyvek, BCE

48. Newman Peter, Thornley Andy (2005): Planning World Cities: Globalization and Urban Politics, Palgrave Macmillan, Basingstoke, Hampshire

49. Ongjerth Richárd (2008): Városrehabilitáció Budapesten, Városközpont megújítás hazai példái Falu-Város-Régió Vol. 2008/2, pp 21-26

50. Owen, Jeffrey (2005): Estimating the cost and Benefit of Hosting Olympic Games: What Can Beijing Expect form Its 2008 Games? in The Industrial Geographer, Volume 3, Issue 1.pp 1-18

51. Pallai, Katalin (2008): The sinuous process - City strategy drafting in Budapest in: Cities in dialogue. Integrated city development, UN-Habitat, 2009

52. Pallai Katalin (2010): Reflection on City Strategy Drafting: Budapest's Sinus Poress 1991-2002 in Ramirez, Ligia; Kebede, Gulelat szerk: Strategic Planning for Local Development: Case Studies form Small and Mid-Sized European Cities, UN-Habitat Sirp - Belgrade, pp 121-134

53. Rattcliffe J., Stubbs M., Keeping M., (2009): Urban Planning and Real Estate Development, 3rd ed., Abingdon, Routlege

54. Ratcliff R. U. (1949): Urban land economics, Westport, Conn: Greenwood Press

55. Roberts, Peter; Sykes, Hugh (2004): Urban Regeneration, a Handbook, SAGE Publications, London

56. Rodgers, Richard (1999): Towards an Urban Renaissance : Final Report of the Urban Task Force, department of Environment, Transport and the Regions, London 
57. Rubin, Herbert J.; Rubin, Irene S. (1995): Qualitative Interviewing: The Art of Hearing Data, Sage Publications, Inc., California (first edition)

58. Rubin, Herbert J.; Rubin, Irene S. (2005): Qualitative Interviewing: The Art of Hearing Data, Sage Publications, Inc., California (second editon)

59. Schneller István (2004): Az épített környezet globális problémái egy nagyváros Budapest - példáján, in Finta József (szerk): Épített jövőnk, MTA Társadalomkutató Központ.

60. Szabó Julianna (2007): A Város és szabályozás: a településrendezés hagyományai és paradigmaváltása, $\mathrm{PhD}$ értekezés BME Urbanisztikai Tanszék

61. Tiesdell, Steve; Allmendinger, Philip (2005): PLanning Tools and Markets: Towards an Extended Conceptualisation in Adams D., Watkins C., White M. (2005): Planning, Public Policy and Property Markets, Blackwell, Oxford

62. Tosics Iván (2004): Elképzelés az átmenti zóna és a barnaövezet jövőjére a Budapest Városfejlesztési Koncepciójában és a kidolgozás alatt álló Középtávú Városfejlesztési Programjában in Barta Györgyi szerk. .A budapesti barnaövezet megújulási esélyei, MTA Társadalomkutató Központ pp327-343

63. Van der Karbben, E.; Lambooy, J. G. (1993): A theoretical framework of the Dutch property market, Urban Studies, Oct 1993, Vol 30 Issue 8, pp 1381-1398. DOI: http://dx.doi.org/10.1080/00420989320081321

64. Vigar, G.; Healey, P.; Hull, A.; Davoudi, S (2000): Planning, Governance and Spatial Strategy in Britain:An Institutional Analysis, Macmillan, Basingstoke. 


\section{Mellékletek}

\section{M1. számú melléklet: A kvantitatív felmérés kérdőíve}

\begin{tabular}{|c|c|c|c|c|c|}
\hline & $\begin{array}{c}\text { Mennyire segít az átalakuló } \\
\text { városrészek színvonalas } \\
\text { megújításában az alábbi eszközök } \\
\text { megfelelő alkalmazása? }\end{array}$ & $\begin{array}{l}\text { jelentős } \\
\text { mértékben }\end{array}$ & $\begin{array}{l}\text { kis } \\
\text { mértékben }\end{array}$ & $\begin{array}{l}\text { nincs } \\
\text { hatása }\end{array}$ & $\begin{array}{l}\text { hátráltató } \\
\text { hatása van }\end{array}$ \\
\hline 1 & $\begin{array}{l}\text { települési jövőképek, koncepciók, } \\
\text { stratégiák kidolgozása }\end{array}$ & 2 pont & 1 pont & 0 pont & -2 pont \\
\hline 2 & $\begin{array}{l}\text { a terület megközelíthetőségét javító } \\
\text { beruházások }\end{array}$ & & & & \\
\hline 3 & $\begin{array}{l}\text { állami, önkormányzati ingatlan- } \\
\text { beruházások megvalósítása }\end{array}$ & & & & \\
\hline 4 & közterületek megújítása & & & & \\
\hline 5 & szabályozási terv készítése & & & & \\
\hline 6 & $\begin{array}{l}\text { müemlékvédelmi, } \\
\text { természetvédelemi területek } \\
\text { kijelölése }\end{array}$ & & & & \\
\hline 7 & $\begin{array}{l}\text { településrendezési szerződések } \\
\text { kötése }\end{array}$ & & & & \\
\hline 8 & $\begin{array}{l}\text { beruházást könnyítő szabályozási } \\
\text { eszközök kidolgozása }\end{array}$ & & & & \\
\hline 9 & $\begin{array}{l}\text { településrehabilitációs pályázati } \\
\text { támogatások kiírása }\end{array}$ & & & & \\
\hline 10 & adókedvezmények & & & & \\
\hline 11 & PPP beruházások megvalósítása & & & & \\
\hline 12 & $\begin{array}{l}\text { építéshatósági engedélyezés } \\
\text { egyszerüsítése, gyorsítása }\end{array}$ & & & & \\
\hline 13 & $\begin{array}{l}\text { ingatlanpiaci információáramlás } \\
\text { segítése }\end{array}$ & & & & \\
\hline 14 & $\begin{array}{l}\text { adott területek megújítást } \\
\text { koordináló szervezetek létrehozatala }\end{array}$ & & & & \\
\hline 15 & $\begin{array}{l}\text { társadalmi konszenzusteremtés a } \\
\text { településfejlesztési célokról }\end{array}$ & & & & \\
\hline
\end{tabular}

A kérdőív kitöltését követően a megkérdezetteknek a jelentős mértékben segítő beavatkozások közül ki kellett választani a három legjelentősebbet. Ezek 4 pontot kaptak az értékelés során. 


\section{M2. számú melléklet: kvalitatív interjúk összefoglalója.}

\section{A fejlesztési környezetet alakító beavatkozások}

A településfejlesztés környezetének alakítását célzó beavatkozások a kvantitatív kérdőívben egyetlen címszó alatt, települési jövőképek, koncepciók, stratégiák megalkotása szerepelt. A válaszok alapján a többség az eszközt fontosnak tartja a települési átalakuló területek megújításában sőt, sokan a legfontosabb három eszköz közé sorolták. „Egy külföldi fejlesztő számára nem a fejlesztési kedvezmény teszi vonzóvá a területet, hanem az, ha lát egy olyan stratégiát, amihez ö illeszkedni tud” hangozott el településrendezői oldalról. Az ingatlanfejlesztők ezt az eszközt kisebb jelentőségünek ítélték, bár a válaszadók véleménye megoszlott a jelentős hatású és a hatástalan minősítések között. Az egyik ingatlanfejlesztő szakember azt jelezte, hogy ő már belefáradt a 3-4 évente változó, ötletbörze jellegü anyagok nyomon követésén, melyekből nehezen hámozható ki karakteres fejlesztési elképzelés. Ugyancsak ingatlanfejlesztői oldalról érkező kritika volt a fejlesztési elképzelések kellő megalapozásának hiánya. De a karakteres, jól érthető és konkrétumokat tartalmazó jövőkép megfogalmazása több másik válaszadó csoport részéről is fontos, a jelenlegi dokumentumok hiányzó elemeként került említésre. A főváros „partraszállás” programjával kapcsolatban például, az egyik föépítész riportalany annak pontos tartalmi meghatározását hiányolta. A célok megjelölése mellett az indikátorok meghatározása, melyek alapján a változások mérhetővé válnak ugyancsak felmerült szempontként. A válaszadók véleménye azonban megoszlott arról, hogy a határozott jövőkép, vagy a stratégia mögötti konszenzus - egymásnak ellentmondani tünő - szempontjai a meghatározóbbak.

A tudatos településpolitika kialakítását a legtöbb riportalany elsődleges eszközként említette a településmegújításban. Az Integrált Városfejlesztési Stratégiák (IVS) kapcsán többen is jelezték, hogy az önkormányzatok többsége azt mint az EU-s támogatások megszerzéséhez szükséges pályázati dokumentumnak tekintik. „Tíz önkormányzatból csak másfél fogja fel, hogy milyen célt szolgál valójában a városfejlesztési stratégia. A többi megcsinálja, mert ezt kérik a pályázathoz” hangzott el az egyik szabadtértervező részéről.

A munkahelyteremtést ösztönző településpolitika, az ennek szempontjait elsődleges szempontként kezelő városfejlesztési stratégia, nagyon sok beszélgetés során szóba került, mint a városmegújítás sikerének záloga. Ennek megvalósításához volt, aki a nagy munkáltatók valamint az innovatív, kitörési pontot jelentő ágazatok bevonását hangsúlyozta a települési stratégiakészítésbe. 
A fővárosi átalakuló területek közül a vasúti területek jelentősége ugyancsak számos interjúban szóba került. Az általános vélemény az volt, hogy a nagy kiterjedésü MÁV területek esetében koncepcióra lenne szükség, mely elkülönítené a vasúthálózat üzemeltetéséhez racionálisan szükséges és az egyéb célokra átadható területeket. A fejlesztési célok között a „city logisztikát” említette az egyik településrendező, mint stratégiai jelentőségü feladatot. Volt olyan, aki azt jelezte, hogy a vasúti koncepcióalkotás már elkésett, mivel a MÁV, telekalakítási jogát kihasználva számos területet már eladott magánszemélyek részére. Más, az államigazgatásban dolgozó megkérdezett véleménye szerint „még nem ment el ez a vonat”, mivel a MÁV telekalakításai számos esetben nem kerültek földhivatali bejegyzésre. A vasúti társaságon belüli sürü vezetőváltások azonban nem segítik a vasúti stratégia megalkotását.

Több föépítész illetve szabadtértervező fontos eszközként jelölte meg az önkormányzati példamutatást. Az önkormányzat saját ingatlanjainak és a közterületeknek a felújításával alakíthatja a terület építészeti „nívóját”. A megteremtett új minőség befolyásolja a magánszektor fejlesztését, mivel a színvonalas közterületek, középületek üzenetet jelentenek a befektetőknek, hogy itt „,jó $a$ gazda”, igényes a közösség.

A stratégia készítésének közigazgatási szintjét illetően többségi vélemény volt, hogy ez fővárosi szintü feladatnak kell lennie. Felvetődött azonban helyi gazdaságfejlesztési koncepció (local economy development plan) müfajának hasznossága is. Ezzel párhuzamosan nyugat-európai példákra hivatkozva, a szociális fejlesztési koncepció (social development plan) ugyancsak egy újszerü és fontos eszközként került említésre. Többen felhívták a figyelmet a fővárosi lakásállományon belül a bérlakások problematikájára. Volt vélemény, mely a szociális bérlakásokon felül, a középrétegek számára elérhető állami-önkormányzati bérlakások jelentősen csökkenthetnék a lakosság hitelállományát és növelhetnék mobilitását. Ehhez koncepcióra lenne szükség a közösségi bérlakás-szektor kialakításáról, jelezte az egyik interjúalany. Egy másik megkérdezett ezt annyival toldotta meg, hogy az egész lakásszektor felújítását és fejlesztését szolgáló koncepció készítése is sürgető feladat. ${ }^{53}$

A stratégia készítés kapcsán a kétszintű fővárosi önkormányzati rendszer problémáira hívták fel az államigazgatásban és a településrendezésben dolgozók közül többen a figyelmet. „Hiba 23 település laza szövetségeként értelmezni a fövárost” hangzott el egy helyen. A javaslatok között a rendezéssel és fejlesztéssel kapcsolatos kompetenciák Fővárosi Önkormányzathoz történő

\footnotetext{
${ }^{53}$ Nagy-Britanniában a pénzügyminisztérium megbízásából készítette el a Kate Barker által vezetet bizottság 2004-ben a Housing Supply (Otthonteremtés) címü tanulmányt. Ennek 36 javaslata között többek közt az állami finanszírozás, adószabályozás, építésszabályozás kérdéseit érintő átfogó javaslatok szerepelnek. (Barker 2004: 1-157)
} 
rendelése, illetve a kibővített hatáskörü Agglomerációs Tanács létrehozása egyaránt felmerült. Elhangzott javaslat a Közmunkák Tanácsához hasonlóan, a fővárosi, állami és EU-s fejlesztési források összekapcsolására. Más vélemény szerint a Közmunkák Tanácsa helyett a mai körülményekhez igazodó, 100 ezres lakosságszámú területrészek üzemeltetésével és fejlesztésével foglalkozó menedzsment szervezetetek tudnák a proaktív tervezés feladatát ellátni. Volt azonban olyan vélemény is, hogy a kétszintü önkormányzati rendszer az nem ok, hanem okozat, amely a politikai megosztottságot képezi le. Ez a megosztottság, és nem a közigazgatási rendszer akadályozza, hogy a város területeinek megújításához a meglévő potenciálját kihasználja.

\section{A fejlesztési környezetet szabályozó beavatkozások}

Az interjúk során a településrendezés rendszerének kapcsán számos, egymásnak sokszor ellentmondó vélemény fogalmazódott meg. Volt olyan, aki a jelenlegi gyakorlatot jónak tartja, viszont a társadalmi, gazdasági közeg olyan, ami nem engedi a rendszert „tisztességesen” müködni. Más vélemény szerint a kétszintű szabályozási rendszer túlbonyolított. Több föépítész hibás gyakorlatként írta le, hogy ingatlanfejlesztők által készíttetett szabályozási tervek születnek, sőt volt vélemény mely szerint „a településrendezési tervek mára kifestőkönyvvé redukálódtak”. Településrendezői részről ez úgy fogalmazódott meg, hogy a rendezés ma már egyre inkább politikai kérdés, a szakmai szempontok súlytalanná válnak. A valódi döntéshozók pedig szakmailag nem kellően felkészültek. Volt olyan vélemény, mely két szabályozási tervjavaslat késztését javasolta. Az egyik készítője az önkormányzat, a másiké az ingatlanfejlesztő lehetne. Ezt követő egyeztetés sorozaton lehetne a kettő elképzelést „összecsiszolni”. A településrendezési tervek közbeszerzési gyakorlatát számos válaszadó bírálta. Az egyik sommás vélemény szerint „ez a gyakorlat olyan, mintha a Nemzeti [Színház] Otelló szerepét annak adná, aki a legkisebb gázsit kéri”. A szabályozási tervek eltérő tartalma ugyancsak problémaként került megjelölésre. Mivel a rendezési tervkészítésekre kiírt közbeszerzési pályázatok legfontosabb - többek szerint kizárólagos -- szempontjai a vállalási ár és a teljesítési határidő, a tervezők a tartalom minimalizálása irányába mozdulnak el. Egy 1:4000-es léptékü szabályozási terv jogi szempontból ugyan olyan, mint egy 1:1000 léptékben készült. Pedig a kettő megvalósíthatósága vélhetően nincs egyforma mélységben végiggondolva, jelezte az egyik válaszoló. Ezzel szemben szabadtérépítészeti oldalról elhangzott a szabályozási tervek túlszabályozottságára vonatkozó panasz, mely akadályozza a ,jó gondolatok megvalósulását”. Ingatlan fejlesztői oldalról ugyancsak a településrendezési tervek alapos átgondoltságának hiánya merült fel. 
Az egyik beszélgetés során ötletként felmerült a szabályozási terv megvalósíthatósági tanulmánnyal történő kiegészítése. Ennek a tanulmánynak a szabályozásban meghatározott szintterületi mutatókból, beruházási költségmutatókból és a térségre jellemző ingatlanárakból kellene igazolnia, hogy a szabályozásban szereplő paraméterek racionálisak. Államigazgatási szakember részéről elhangzott, hogy a magyar településépítészet különböző korszakaiban volt úgy, hogy nem a jogszabályok, hanem a szabványok vagy irányelvek domináltak. De akár szokásjog alapján is történhetne a megkérdezett szerint a szabályozás, ha az ettől való eltérés szankcionálása megoldott lenne. A szabályozás tartalmi követelményeinek megváltoztatását illetően több javaslat is megfogalmazódott. Az egyik a válaszadó beépítési százalék fölöslegességét és a szintterületi mutató hiányosságát emelte ki. E helyett a hektáronkénti lakásszám, illetve lakos számot javasolták többen is bevezetni. Több interjú esetében felmerült a zöldterületi, illetve zöldfelületi normatíva bevezetésének szükségessége. Ezzel kapcsolatban a $14 \mathrm{~m}^{2}$ közkert/lakás, $9 \mathrm{~m}^{2}$ közcélú zöldfelület/fö, illetve a korábbi 3x7 m2 normát említették. Ezen javaslatok az OTÉK módosításának igényét jelzik, mely kapcsán tájépítészi oldalról (mind településrendezéssel, mind szabadtértervezéssel foglalkozó szakemberek) a zöldfelület hangsúlyosabb szerepeltetését tartották szükségesnek a megkérdezettek. Példaként a zöldterületek hiányzó zöldfelületi minimum értéke hangzott el. Az egyik szabadtértervező felhívta a figyelmet arra az érdekes párhuzamra, ami a sokat bírált ingatlanfejlesztők és az állam között vonható. Az ingatlanfejlesztések során többször lehet szembesülni, hogy a marketingben hangsúlyosan megjelenő környezeti szempontrendszer (pl. kert-, park-, liget megnevezés a beruházás fantázianevében) az elkészült objektumban már alig lelhető fel. De ehhez hasonlóan viselkedik az állam is, amikor az általa is elfogadott nemzetközi dokumentumokba (pl. Lipcsei Charta, Toledói Dekrétum) hangsúlyosan megjelenő környezetminőségi, ökológiai szempontokat lassan elkoptatják a törvények, rendeletek, végrehajtási utasítások láncolata során. Ehhez a problémához kapcsolódóan jelezte az egyik interjúalany, hogy a MÉK Táj- és Kertépítészeti Tagozata, illetve a Magyar Tájépítészek Szövetsége pontokba szedte az OTÉK ,zöldítésével” kapcsolatos javaslatait. ${ }^{54}$

A fővárosi lakóterületi fejlesztésekkel kapcsolatos kritikaként fogalmazódott meg, hogy ha nem is jogtalan, de a közösségi érdekekkel nem egyező az a gyakorlat, ahogy ingatlanfejlesztők és kerületi önkormányzatok az FSZKT intézményi keretövezetében lakóparkokat fejlesztenek. Más vélemény szerint, amennyiben a főváros közösségi intézmények létesítésére való területet határoz meg, úgy azt a saját tulajdonában kellene tartani vagy törekednie kellene a terület megszerzésére.

\footnotetext{
${ }^{54}$ Az OTÉK módosításokra vonatkozóan a 17 pontba szedve fogalmazza meg a dokumentum a javaslatait, melyek közül a leglényesebbek (a szerző véleménye szerint): a szabályozási tervek alátámasztó munkarészeinek tartalmi követelményeinek pontosítása, a mezőgazdasági területek nagyobb differenciáltsága, a közterületi fák védőtávolságának kijelölése, sủrün lakott városrészek esetében differenciáltabb parkolási normatíva, zöldfelületi normatíva bevezetése, a közterületekre és szabad terekre vonatkozó passzusok jobb kidolgozása. (MÉK TT, MKTSZ 2011: 1-17)
} 
Településrendezői részről hangzott el szintén az a vélemény, hogy a valós igényekhez igazodó mennyiségű keretövezet kijelölése lenne szükséges. Államigazgatási részről viszont egyenesen az fogalmazódott meg, hogy ma már a BVKSZ, mely még mindig OÉSZ alapon szabályoz, „minden harmadik sora ellentmond az OTÉK-nak”. Ez a jogszabályi ellentmondás jogbizonytalanságot eredményez. Ezért, illetve törvényi elöírás miatt is sürgető a fővárosi szabályozás rendszerének az országos jogszabályokhoz való igazítása.

A közterületek kialakítása kapcsán többen felvetették a közterület fejlesztési vagy közterület szabályozási terv müfaji megteremtésének kérdését. A közterületek kialakításának ez az eszköze a szabályozási tervek és a kivitelezési tervek közötti eszközként jöhetne létre. Volt olyan válaszadó, aki az arculati tervhez hasonlította ezt az eszközt, mely a minőségi és funkcionálisan átgondolt közterületek létrejöttét segíthetné. A tervfajta kialakítását mások a közterületek kivitelezési engedélyeztetésének jelenlegi állapotával indokolták, ahol számos hatósággal és hatóságként viselkedő (közmü) szolgáltatóval kell a tervet engedélyeztetni, és „,lehet, hogy mire az utolsó engedélyt beszerzi a tervezö, az elsö már le is járt."

A müemlék- és természetvédelemről beszélő riportalanyok jelentős mértékben árnyalták a kvantitatív interjúk kapcsán a müemlékvédelemről mint eszközről kialakuló negatív képet. A riportalanyok mindegyike jelezte, hogy ezek az épített és természeti értékek fontos erőforrásai a településeknek. A problémát a megkérdezettek gyakorlatilag egyöntetủen, az egyoldalúan csak kötelezettségeket megfogalmazó szabályozásban látták. Az érintetteket - például támogatások rendszerével - érdekelté kell tenni az értékek megőrzésében, hangzott el az egyik beszélgetésen. Az egyik főépítész jelezte, hogy önkormányzatuk helyi védelmi rendelete mellé plusz támogatási forrásokat jelölt ki az elmúlt év során. Másik jó példaként a Wekerle telepen lévő védett épületek felújítását segítő ablak felújítási program került megemlítésre. A müemlékvédelmi hatóságok „,maradiságát” is bírálta egyik válaszadó. „Jó lenne, ha a müemlékvédelmi szakma megérkezne a 21. századba”, hangzott el a sommás vélemény. Minisztériumi tervek között szerepel egy ajánlás összeállítása arról, hogy a mủemléki védelem alá vonással párhuzamosan hogyan teremthetők elő többlet források az adott helyszín fenntartására, jövedelemtermelő képességének növelésére.

Az interjúk során a településrendezési szerződésekről azt emelte ki az eszközt hasznosnak tartó egyik válaszoló, hogy „ennek segítségével az [ingatlanberuházással] létrejövő értéktöblet részben visszafordítható a közösség használra”. Az eszközt határozottan bíróló ingatlanfejlesztők azt jelezték, hogy ezzel „újabb és újabb bőröket próbálnak lehúzni a befektetőkről”. Az egyszerü érdekellenténtek látszó helyzetet azért több tényező is árnyalja. Az állami szférában dolgozó egyik 
interjúalany jelezte, hogy ennél a viszonylag új eszköznél még nem áll rendelkezésre elegendő tudás annak pontos meghatározásához, hogy egy-egy beruházás ténylegesen mennyi extra költség elviselésére képes. Az eszközt kritizáló ingatlanfejlesztők hangsúlyozták azonban, hogy kritikájuk a településrendezési szerződéskötés jelenlegi fővárosi gyakorlatára vonatkozik. ${ }^{55}$

Az interjúk során az ingatlan értéknövekedési adó kérdése többször elökerült. Az adó céljaként részben a telekspekulációs célú ingatlan átsorolások korlátozása, részben településrehabilitácós pénzügyi forrás megteremtését jelölték meg a válaszadók. Az adó nagyságát illetően az ingatlanérték 2\%-ának megfelelő összeg hangzott el. Volt aki arra emlékezett, hogy Baráth Etele minisztersége alatt ${ }^{56}$ volt kísérlet ennek bevezetésére, de lobbiérdekek ezt megakadályozták. Az adó fizetési köteletsséget többek véleménye szerint az ingatlan adás-vétel létrejöttéhez kötnék. Az adó megnevezéseként a srófadó ${ }^{57}$ illetve a betterment ${ }^{58}$ adó is elhangzott. Az önkormányzati krónikus forráshiány pótlásának egyik lehetséges eszközeként az ingatlanadó eszköze merült fel. Településrendező vélemény szerint az iparüzési adó elvonása a fővárosi kerületi önkormányzatoktól hiba, mivel nem ösztönzi kellőképpen a munkahelytermetést. Ingatlanfejlesztői részről merült fel a karbon lábnyom adó. Ez Ausztrália példájára magasabb adóval súlytaná a környezetet terhelőbb, és jutalmzná a környezetet kevésbé terhelő fejlesztéseket. ${ }^{59}$

\footnotetext{
55 A Településrendezési Szerződésekkel az Ingatlanfejleszői Kerekasztal illetve a RICS(Royal Institute of Chartered Surveyors) Hungary közös álláspontot alakított ki, melyben sorra veszik jelenlegi rendszer problémáit: egyedi és eseti döntések, korupcióveszély, jogellenes alkalmazási gyakorlat, több felet tartalmazó projekt kezelésének lehetetlensége, nagyobb terület esetén a projektek ésszerütlen tagolása és potyautas efektus, a kétszintü önkormányzati rendszerből adódó szerződéskötési nehézségek, tulajdonosváltás esetén a szerződés végrehajtatásának nehézsége. Ezen túlmenően javaslatot is adnak egy jobban müködő rendszer kidolgozására: több tulajdonos estén kötelezés alapú normatív rendszer, az elöírható beruházások pontos meghatározása, önkormányzati kötelezettség vállalás a szabályozás, az eljárás pontos szabályozása, későbbi magánfejlesztők arányos részvállalása, főváros és kerületkek viszonyának rendezése, a tulajdonosra terhelhet összeggel szembeni jogorvoslat lehetővé tétele. (Czike Gábor 2011: 1-8).

${ }^{56}$ Baráth Etele építész végzettségü politikus 2004-ben európai ügyekért felelős tárca nélküli miniszteri kinevezést kapott Gyurcsány Ferenctől. „Ő felügyelte a Nemzeti Fejlesztési Hivatal és az Európai Ügyek Hivatalának munkáját is.” http://hu.wikipedia.org/wiki/Bar\%C3\%A1th_Etele

${ }^{57}$ A srófadó a korábbi és a tervezett beépítés közötti különbséget adóztatja meg exponenciálisan növekvő módon. Az adó célja a „túlépítési vágy mérséklése” (Mihály 2010)

${ }^{58}$ Az 1967-ben Nagy-Britanniában bevezetett Betterment Levy nem bizonyult kellően hatékony szabályozási eszköznek. 2004-ben Kate Barker által vezetett bizottság az ingatlanfejlesztések adóztatásának lehetőségeit áttekintve javaslatot tett Planning-gain Suplement (PGS) nevü adófajta bevezetésére. Az adó az ingatlan értéknövekedést terheli, ami az építési engedély kiadása utáni ingatlanérték és a korábbi ingatlanérték különbsége. Az adó az építési engedély kiadásakor válik esedékessé. A tanulmány hangsúlyozza, hogy az adó valós és mérhető értéknövekedést kell terhelnie, egyszerüen kivethetőnek kell lennie azonban a kivetés során a beruházó cash-flow folyamataira tekintettel kell lennie, hogy ne lehetetlenítse el a beruházást. (Baker 2004: 78) Fontos megjegyezni, hogy a javaslat az „Otthonteremtés” (Housing Supply) című pénzügyminisztériumi tanulmány részeként készült, menynek tulajdonképpeni célja a lakás célú fejlesztések ösztönzése volt. A javaslat hangsúlyozza, hogy az adó mértékét nem szabad olyan szinten megállapítani ami a fejlesztéseket blokkolja. Az adó mértékének differenciálását viszont javasolja a tanulmány, a barnamezős területek priorizálása céljából. (Barker 2004: 139)

${ }^{59}$ Ausztrália 2011 novemberében szén adót fogadott el, mely értelmében a vállalkozások a tevékenységük révén a légkörbe kibocsátásra kerülő szén után tonnánként 23 AUD-t fizetnek. Az adó mértéke 2015-ig fokozatosan emelkedni fog. http://www.carbontax.net.au/category/what-is-the-carbon-tax/
} 
Szabadtértervezők részéről jelezték többen, hogy ingatlanfejlesztési beruházások során végső soron mindig a közterületi, zöldfelületi elemekből „csípnek le”, mikor a költségkeret elégtelennek bizonyul. Jó példaként a MOM park beruházás került említésre, ahol a beruházási költségeket nem lehetett átcsoportosítani ágazatok között. Illetve hasznos eszöközként említették a kivitelezési költségtendernél a „jóminőség garanciát”, mely arra vonatkozó kötelezettségválalás, hogy a kivitelezés valóban megvalósítható a tervező által becsült összegböl.

A főváros átmeneti zónájával, a „klasszikus barnamezővel” kapcsolatban a területek tulajdonosi felaprózodottságának megszüntetését elősegító eszközre vonatkozó javaslat hangzott el. A javaslattevő véleménye szerint a PTK-ban lenne szükséges szabályozni az „ipari-társasházi” viszonyokat, annak érdekében, hogy a kissebségi tulajdonosok ne akadályozhassák meg a többség rendezésre való igényét. Elhangzott továbbá építési moratórium bevezetéséenek a lehetősége a rozsdaövezeten kívli beépítettlen területekre vonatkozóan, az átmeneti zóna megújulásának előssegítésére.

\section{A fejlesztési környezetet élénkítö beavatkozások}

A fejlesztési környezetet élénkítő eszközök kapcsán az interjúk során sok kritika fogalmazódott meg a jelenleg aktuális EU forrásokra épülő pályázatokat illetően. Leginkább a pályázati keretek merevsége, bürokratikusságát említették negatívumként a válaszadók. A pályázati kiírás követelményei miatt olyan elemek is bekerülnek a pályázatokba, amiket az adott helyszín nem igényelne. „Nem a gombhoz kellene a kabátot igazítani”, utalt az egyik megkérdezett arra, hogy átgondolt fejlesztések helyett az aktuális pályázatok határozzák meg a településfejlesztési célokat. Ugyanakkor voltak vélemények, melyek szerint a pályázati kiírások az Európai Unió irányelveihez igazodva kerülnek kiírásra, és így olyan fejlesztési szempontokat is érvényesíthetnek, melyeket maguktól az önkormányzatok kevésbé tartanának fontosnak. A pályázat elbírálása során hiányzik a szakmaiság, döntően bürokratikus szempontok érvényesülnek, hangzott el egy másik kritika. Problémának jelezték, hogy engedélyezéséi dokumentum alapján beállított mutatókhoz ragaszkodnak mereven a pályázatértékelők. Többen jelezték, hogy nagyon fontosak a sokszor „,nem kellöen produktívnak” titulált szabadér megújítási pályázatok, hiszen járulékos hasznuk városrészre, esetenként a város egészére kiterjedő lehet. Problémaként fogalmazódott meg, hogy ezek a járulékos hasznok (új vendéglátóhelyek megjelenése, bérleti díjak emelkedése, turisztikai vonzerő növekedés) nehezen számszerűsíthetők. 
Az ingatlanfejlesztéssel kapcsolatos adókedvezmények kapcsán az interjúk során konkrét javaslatként a műemléki védettségü épületek megújításának segítése érdekében ezek ÁFA mentessé tétele hangzott el. Másik konkrét javaslatként az ingatlan értéktöbblet adó hangzott el, amelybe barnamezős területek megújítását ösztönző elem is illeszthető lenne. ${ }^{60}$

A kérdőív következő kérdése a beruházást könnyítő, újszerü szabályozási eszközök bevezetésének lehetséges szerepét vizsgálta. Több interjú alany visszakérdezett ezzel kapcsolatban, hogy ez voltaképpen mit jelent. Ilyenkor a Nagy-Britanniai Enterprise Zone (kb. Beruházási Övezet) intézményét említettem, mint egy lehetséges eszközt. ${ }^{61}$ Az interjúk során föépítészi részről hangzott le, hogy a jelenleg zajló „Sukoró per”62 is mutatja a beruházást könnyítő különleges eszközök kijelölésével járó veszélyeket. Ingatlanfejlesztői részről a Szél Kálmán tér megújítása merült fel, mint olyan példa ahol valamilyen különleges területi státusz segíthetné a hosszú ideje húzódó felújítási folyamatot. ${ }^{63}$

Egy adott átalakuló terület megközelíthetőségét javító beruházások kapcsán az interjúk során többen kiemelték, hogy a Váci úti irodafolyosó létrejöttének a legfontosabb oka az út alatt haladó metróvonal. Ingatlanfejlesztői oldalról hangzott el az a kritika, hogy attól hogy egy „csomóponti terület fejlesztését bedobja [a szakmai közbeszédbe] stratégia néven az önkormányzat”, attól az még nem válik befektetésre vonzó területté. Ehhez elsősorban az adott terület megközelíthetőségét kellene megoldani.

\footnotetext{
${ }^{60}$ A Kate Barker féle bizottsági jelentés az otthonteremtés segítése érdekében Planning Gain-suplement néven javasol értéknövekedési jellegü adó bevezetését. Az adó mértékét azonban differenciálni javasolja a tanulmány, a barnamezős területek priorizálása céljából. (Barker 2004: 139)

${ }^{61}$ Az Enterpise Zone gondolatát Peter Hall vetette fel először 1977-ben a RTPI chesteri konferenciáján. Elképzelése melyet hangsúlyozottan egyedi és különleges helyszíneken javasolt megvalósítani - jogi szempontból egy állam az államban terület jönne létre a városok belső, megújulásra képtelen területein. A Hongkongi ihletésű javaslat értelmében a területen a településrendezés szigorú szabályai (sőt a bevándorlási szabályok) alól mentes beruházási övezet jönne létre, ahol a bürokráciától mentesített vállalkozó tőke szabad kezet kapna a terület megújítására (Hall 1996: 356). 1980ban a konzervatív kormány az elképzelés megvalósítása mellett döntött. Azonban az eredetileg unortodox módszereket megfogalmazó radikális modell meglehetősen átalakult az konzervatív adminisztráció berkeiben. Az országosan kijelölt tíz Enterprise Zone területe valóban mentesült számos adó és járuléktehertől, illetve építésszabályozási előírástól. Azonban a fő vonzerőt a területeken megvalósuló beruházásokhoz nyerhető állami támogatás volt. A területek fejlesztési beruházásait az erre kijelöld Development Coorporation-ok (Fejlesztési Társaságok) koordinálták. (Hall 1998: 920).

${ }^{62}$ A szöveg írásakor büntető eljárás volt folyamatban Gyurcsány Ferenc volt miniszterelnök és több társa ellen a 2009ben kiemelt beruházási státuszt nyert King's City beruházás révén az államot ért vélt hátrányok miatt. A volt miniszterelnök az eljárást koncepciózusnak nevezi.

http://www.budaigyula.hu/index.php?option=com_content\&task=view\&id=348\&Itemid=1

http://sukoroper.wordpress.com/

${ }^{63}$ A három kerület határán elhelyezkedő Szél Kálmán Térre (egykori Moszkva térre) 1999-óta több közterületi felújítási terv született, a megújítás máig nem indult el.

http://hg.hu/cikk/epiteszet/11510-moszkva-teri-fantaziak

http://hvg.hu/itthon/20110928_szell_kalman_ter_felujitas
} 
Az állami, önkormányzati ingatlanberuházásokról kérdevze a riportalanyok közül volt aki ezt a típust a legjelnetősebb három eszköz közés sorolta, míg másik interjúalany vélemnye szerint, a fővárosi - válság időszakon kívüli - ingatlanfejlesztések arányát tekinte ezekneknk nincs számottetvő hatása.

A közterületek megújítása ismét egy egyöntetüen támogatott eszközként szerepelt, és a kérdezett csoportok közötti véleménykülönbségek itt volt a legkisebbek az élénkítés eszközeinek keretében. Az egyik ingatlanfejlesztő riportalany jelezte, hogy belső városrészek forgalomcsillapítási valamint a közpark fejlesztési beruházások olyanok, melyek egyértelmüen felértékelnek egy adott területet. Ezt a Belváros-Lipótváros jelenlegi és Ferencváros volt főépítésze egyaránt megerősítette. Az előbbi a Kossuth Lajos utcát, az utóbbi Lenhossék parkot hozva fel példának arra, ahol a közterületi felújítás az ingatlanok értékét illetve a bérleti díjakat jelentős mértékben növelték. Más főépítész arra hívta fel a figyelmet, hogy a közterület felújítás eszköze a jelentős mértékben lepusztult területeken önmagában nem hatékony. A forgalomcsillapítás eszközével kapcsolatban a járulékos beruházások elmaradását jelölte meg problémának az egyik megkérdezett. A forgalomcsillapítás kapcsán csökkenő parkolóhelyek pótlása (parkolóházban, mélygarázsban) része kellene legyen ezeknek a felújításoknak. A közterületi felújítások előnyeként emelték ki többen, hogy az ingatlanfelújítáts összegének töredékéért megvalósítható, és eredménye a terület identitásának megerösítése révén a környező területek számára is érzékelhető változást eredményez. Több megkérdezett is jelezte, hogy a közterületi felújítások közvetetett hatásainak mérése fontos, de nem könnyü feladat. Az egyik szabadtértervező interjúalany a Green City mozgalomra hívta fel a figylemet, mely ezeknek a közvetett hatásoknak a mérésére megpróbál objektív eszközöket kidolgozni. $^{64}$

A Public Private Partnerhis (PPP) témakört érintve a megkérdezettek küzül többen jelezték, hogy a kvantitatív interjúban adott negatív véleményük a a közelmúltban megvalósult PPP beruházások gyakorlatára vonatkozik. Továbbá azt is jelezték többen, hogy jogszabályi okok miatt a közeljövőben nem is várható ilyen beruházások elindítása. ${ }^{65}$ Volt interjúalany aki jelezte, hogy a

\footnotetext{
${ }^{64}$ A Green City mozgalom a Plant Pulbicity Holland, faiskolai szervezet által létrehozott lobbi mozgalom, melynek a célja a zöldfelületi fejlesztések népszerüsítése. Honlapjukon, számos kiadvánnyal igyekeznek érveket felsorakoztatni amellett, hogy a zöldfelületi fejlesztésekének milyen társadalmi, gazdasági, környezeti hasznai vannak. http://www.thegreencity.eu/ Magyar szervezettel is rendelkező hálózat akkreditációs pontrendszer kidolgozását készíti elő, ahol projektek és települések is minősíthetik magukat ökológiai szempontokból. http://www.green-city.hu/

${ }^{65}$ A Állami Számvevőszék jelentése alapján a „PPP konstrukció „,nem szolgálja az állam érdekeit, és leginkább arra jó, hogy magáncégeknek állami segítséggel jussanak biztos bevételhez”. (http://www.origo.hu/itthon/20101018-a-pppberuhazasok-leallitasat-tervezi-a-kormany.html). A Nemzeti Fejlesztési Minisztériumban külön államtitkárság fogadkozik a 2003-2010 közötti PPP szerződések felülvizsgálatával. Az államtitkár szerint a PPP konstrukciókat akkor alkalmazzák „ha az államnanknincs pénze egy beruházásra, ugyanakkor nem akar rá hitelt felvenni, nem akarja növelni az államadósságot.” http://hvg.hu/velemeny/20110126_ppp_nagyberuhazas_szerzodes
} 
rossz példák ellenére ez is lehet egy hasznos eszköze a településmegújíátnak. Ennek a fő kritériuma, hogy az állam ne csak a kockázatokat vállalja át a magánfejlesztőtől, hanem az üzleti haszonból is részesüljön, valódi partnerek legyeneka felek „együtt sírjanak, együtt nevessenek”. Volt interjúalany aki jelezte, hogy a PPP konstrukcióban megépült fővárois létesítmények közül a MÜPA és a SOTE Tahi Kálmán utcai épülete jelentősen hozzájárulnak a környezetük megújulásához. Sőt, az egyik főépítész részéről olyan válasz is elhangzott, hogy tulajdon képpen a jól múködő településfejlesztés nem más mint, az állam és magán szféra közötti partneri együttmüködés.

Az építési engedélyezési eljárás gyorsítása kapcsán volt ingatlanfejlesztő, aki a kormányzati politikák ellentomdásosságára hívta fel a figyelmet. Míg az építési engedélyezés eljárásrendje helyesen - egyszerüsödik, addig más engedélyezéshez kapcsolódó eljárások, egyedi döntési mechanizmusok (tüzrendészeti eljárás, kötelező építtetői fedezetkezelők ${ }^{66}$, pláza stop ${ }^{67}$ ) bonyolítják és lassítják a beruházási folyamatokat. Az egyik főépítész véleménye szerint míg a stratégiai döntéseket nem helyes siettetni, az építési engedélyezésnél ennek van helye. Több településrendező ezzzel szemben annak adott hangott, hogy egy kellően előkészített projekt esetében, az építés engedélyezés gyorsítása nem jelent számottevő előnyt.

A közműszolgáltatók hatósági szerepkörét több interjúalany is a településmegúítás szempontjából jelentős problémaként vetette fel. Volt aki egyenesen úgy fogalmazott, hogy a közmüszolgáltatók „diktatórikus és megkérdőjelezhetettlen hatalommal bírnak”, ami a közterületek kreatív megújítáást nehezíti. Más megkérdezett azt jelezte, hogy a közműszolgáltaók hatósági szerepkörét el kell választani a szolgáltató szerepkörttől. A tüzoltóság mint szakhatóság „,vaskalapossága” ugyancsak említésre került olyan problémaként, mely a közterületi megújítást, különösképpen a fasorok telepítését nehezíti. Külön kiemelésre került a közmü nyilvántartás problematikája, ahol a nem egységesen kezelt, drágán hozzáférhető alapadatok nehezítik a településmegújítás tervezését.

\footnotetext{
${ }^{66} 2009$ őszén a „Gyorsítás II” csomag részeként hozta létre a kormány az építetői fedezetkezelő jogintézményét. Ennek értelmében „amennyiben az adott építési projekt fedezetkezelö igénybevételét teszi kötelezővé, úgy az építtető köteles fenntartani egy fedezetkezelöi bankszámlát az építtetői fedezetkezelönél, amely számla felett a kizárólagos rendelkezési jog a fedezetkezelöt illeti. Ezen fedezetkezelöi bankszámlára az építtetö az építési ütemtervnek megfelelöen köteles a kivitelezés minden egyes ütemének anyagi fedezetét átutalni. A fövállalkozó és az alvállalkozók nem kötelezhetöek az. egyes munkaütemek megkezdésére, amíg az adott munkaütem fedezetét nem utalták át a fedezetkezelői számlára. 0 áprilisától a jelentős mértékü beruházásoknál kötelező építtetői fedezetkezelö igénybevétele.” 191/2009.(IX.15.) Kormányrendelet az építöipari kivitelezési tevékenységről http://www.portfolio.hu/gazdasag/epittetoi_fedezetkezelo _uj_szereplo_az_epitesi_beruhazasokban.129255.html

${ }^{67}$ A kormány az ÉTV 2012-es módosításában megtiltotta a 300 m2-nél nagyobb alapterületű kereskedelmi építmények létesítését. Ez alól „a kereskedelemért, a környezetvédelemért és a vidékfejlesztésért felelös miniszterek részvételével müködtetett Bizottság véleményének kikérésével a kereskedelemért felelös miniszter felmentést adhat.” ÉTV 53/F.(2). Az interjúalanyok felhívták a figyelmet, hogy a Bizottság müködésének részleteiről nincsenek rendelkezések.
} 
A szabadtér megújítási pályázatok mellett, a társasház megújítási pályázatokat említette az egyik interjúalany mint a települések átalakuló területeinek megújítása szempontjából jelentős eszközt. Ingatlanfejlesztő oldalról is jelezték, hogy létezik a településmegújításnak egy kisléptékü, mozaikos verziója, amikor a területen lévő tülajdonosok újjítják meg a saját ingatlanaikat. Ezt felújítási támogatásokon kívül, kisléptékü közterület megújításokkal ösztönözheti az önkormányzat. Főépítészi oldalról az egyik interjúalany szintén a kisléptékü közterületi felújítások fontosságát emelte ki annak érdekében, hogy folyamatosan mozgásban legyen a településmegújítás „lennkereke”. Másik fóépítész hangsúlyozta, hogy a meglévő beépítések minőségi megújítása és fenntartása legalább olyan jelentős feladat, mint a jelentős átépítésekkel járó felújítások. Hibaként írta le, hogy „a fejlődés nálunk sokan csak mint számszerüsíthető [mennyiségi] fejlödést” határozzák meg. Másik interjú során az hangzott el, hogy a meglévő beépítések tulajdonosi, részben önerős megújulásokhoz a társasházakat alkalmassá kell tenni a rehabilitációs pályázatokon való hatékonyan résztvételre. Ez a témakör a kapacitásfejlesztés területére vezet át bennünket.

\section{Kapacitásfejlesztő beavatkozások}

A kvantitatív felmérés során három kapacitásfejlesztéssel kapcsolatos eszköz közül az ingatlanpiaci információ áramlás segítését említve a főépítészek közül többen a legjelentősebb három intézkedés közé sorolták az információáramlás segítését. Volt föépítész aki megemlítette, hogy az önkormányzat jelenleg is ingtalan információs , ügynökségként” müködik informális módon, de jó lenne ha a rendszer nyitottabbá váhatna. Más megkérdezett azt jelezte, hogy összvárosi szinten lenne célszerü egy „készletkönyv” összeállítása a különböző fejlesztési funkciók számára már előkészített beruházási helyszínekről. Ingatlanfejlesztői részről nem az információ döntő fontosságát kérdőjelezték meg, hanem a fejlesztők azt közölték, hogy nekik már jól kidolgozott módszereik vannak a számukra értékes információ beszerzéséhez. Szabadtértervezők részről annak fontosságát emelte ki az egyik megkérdezett, hogy a megvalósuló nagyvolumenü köztérrehabilitációs programok tanulságait nagyon fontos lenne alapos elemzésre bocsátani. A jelenleg folyamatban lévő EU projektek kapcsán számos, a településmegújítás különböző szempontjaiból hasznosítható információ gyüjthető össze, aminek elemzése és az eremdények megosztása kormányzati feladat lehet.

A következő kérdés a társadalmi konszenzusteremtésre vonatkozott a településfejlesztési célokról. Ezzel kapcsolatban több megkérdezett jelezte, hogy teljes konszenzus elérése még egyszerü ügyekben is nehéz, így a teljes konszenzusra való törekvés ellehetetleníthet fejlesztéseket. 
Ingatlanfejlesztői oldalról az a vélemény fogalmazódott meg, hogy a világos és határozott településfejlesztési irány kijelölése a döntéshozók által fontosabb a társadalmi konszenzusteremtésnél.

Az adott terület megújítást koordináló szervezetről beszélgetve az interjúk során kiderült, hogy azok a válaszolók, akik nem tartották a kvantitatív felmérésben fontosnak ilyen szervezet létrehozását, azok közül többen úgy gondolták, hogy az önkormányzaton belül kellene ezt a feladatot ellátni. Abban egyetértés mutatkozott, hogy az önkormányzatok jelenlegi szervezeti struktúrájukban nem képesek településfejlesztés menedzsmenti feladatok hatékony ellátására. Volt azonban olyan vélemény is, hogy az önkormányzat által létrehozott szervezetekben általában a „Peter elv és a Parkinson törvény kezd müködni” "68. Volt aki Studio Metropolitánát nevezték meg, mint olyan szervezetet, ami forrás és világos felhatalmazás híján nem tudott hatékony településmenedzsmenti szervezetté válni. Más megkérdezett a Budapesti Közlekedési Központot említette, mint jó példát fővárosi szinten stratégiaalkotásra és integrálásra képes szervezetre, mely „hivatalnokok és üzemeltetők közé visz be stratégiai gondolkodást”. A Józsefvárosi Rehabilitációs és Városfejlesztési Zrt (RÉV 8) kapcsán az a vélemény hangzott el, hogy annak hatékony müködését a vele szorosan együttmüködő ingatlanfejlesztő tette lehetővé. A Ferencvárosi Városfejlesztő Zrt. (SEM IX.) volt ezzel szemben, amely többek részéröl, mint pozitív példa került bemutatásra. Az egyik ingatlanfejlesztő szerint ez a szervezet a ferencvárosi beruházási környezetet kiszámíthatóbbá tette, illetve gazdaként törekedett a felmerülő problémák megoldására. Másik válaszadó szerint az ilyen településfejlesztési szervezet az önkormányzati döntéshozatali folyamatot teszi gyorsabbá, egyszerübbé. Több válaszadó is azt jelezte, hogy professzionális városfejlesztő társaság létrehozatala fővárosi szinten lenne szükséges. A szervezet feladatait elég hasonlóan írták le a megkérdezettek. A szervezetnek a településfejlesztés irányítása lenne a fő feladata, ami azonban nem zárná ki a profit generálását, ami visszaforgatható a városfejlesztésbe. Más azt emelte ki, hogy ennek a nonprofit szervezetnek a feladata az ingatlanfejlesztések elindításának segítése lenne hangsúlyosan olyan helyszíneken, ahol a piaci szereplők segítéség nélkül nem kezdenének fejlesztésbe. Más válaszadó azt húzta alá, hogy az ilyen társaság segíthetné az önkormányzat és a fejlesztők közötti együttmüködést és párbeszédet, megváltoztatnák azt a gyakorlatot, hogy „,az ingatlanfejlesztő diktál”. Volt, aki ennek kapcsán azt hangsúlyozta, hogy „a településfejlesztés nem egyenlö az ingatlanfejlesztéssel”. Többen fontosnak tartották megjegyezni, hogy egy ilyen

\footnotetext{
${ }^{68}$ Peter elv értelmében egy szervezetben, ahol az előléptetés a sikerességen múlik, egy az alkalmazott általában azon a poszton marad leghosszabb ideig, amely ellátására már nincs kellő kompetenciája. http://en.wikipedia.org/wiki/Peter_Principle

Parkinzon törvénye értelmben egy adminisztratív szervezetben a munkához szükséges idö kitölti az elvégzésre maximálisan rendelkezésre álló időtartamot http://en.wikipedia.org/wiki/Parkinson\%27s_law
} 
szervezetben mind tulajdoni arányban mind döntési kompetenciával az önkormányzatnak megfelelően képviseltetnie kell magát. Volt interjúalany, aki felhívta a figyelmet, hogy a köztér megújítási pályázatok kapcsán több kerület létrehozott projektmenedzsment társaságot. Az, hogy ezek mennyire látnak el átfogó stratégiaalkotó és menedzsment szervezetté, az az adott önkormányzat egyedi döntéseitől függ. Ahhoz, hogy egy ilyen szervezet tartós eredményeket érjen el, ahhoz nem projektlebonyolító, hanem hosszútávon gazdálkodó szervezetként kell müködnie, vélte az egyik megkérdezett. ${ }^{69}$

Az interjúk során több a kapacitásfejlesztés eszközrendszeréhez sorolható intézkedés merült fel. Az egyik ilyen az összvárosi szintű és önkormányzathoz kapcsolódó tervezőiroda, kutató intézet vagy ahogy az egyik interjúalany nevezte „agytröszt” létrehozása. Ez az intézmény nem csak a stratégiák készítésében, konkrétumokra bontásában vállalna operatív szerepet, de feladata lenne a megvalósulás nyomon követése, „a jövőkép és a valóság összevetése”. Volt, aki Bécs önkormányzatának 300 főt foglalkoztató tervezőirodáját említette mint jó példát. Főépítész részről föépítész, főmérnök, városigazgató szerepkör hármas kidolgozásában látta az egyik megkérdezett a hatékony önkormányzati menedzsment biztosítását. Más válaszadó az előző két javaslat együtteseként egy főépítész, főmérnök, főkertész és menedzser által koordinált, vétó joggal rendelkező tanácsadó testület irányítása alá szervezett tervezőirodát javasolt.

A szakmai oktatás és képzés szerepére ugyancsak többen kitértek. Államigazgatási oldalról, de szabadtértervezők részéröl is elhangzott, hogy - kistelepülésekre inkább jellemzően - az önkormányzati képviselők, illetve a polgármesteri hivatali dolgozók esetében esetenként súlyos jogi és szakmai ismerethiányok fedezhetők fel. Az állam feladata kellene a megfelelő szakmai továbbképzések lehetőségének biztosítása legyen. Ingatlanfejlesztői oldalról pedig az ingatlanfejlesztői szakma megfelelő színvonalú egyetemi oktatásának hiányára hívta fel az egyik interjúalany a figyelmet. Reményei szerint a jelenleg formálódó egyetemi szintű ingatlanfejlesztői képzés segít majd abban, hogy a szakma sokszor negatív megítélése fokozatosan javuljon.

A szakmai szerveződés volt a másik olyan irány, melytől a válaszadók a hatékonyabb érdekképviselet mellett, a jobb minőségű szakmai tevékenység feltételeinek megteremtését és általában, a településfejlesztés színvonalának javulását remélték. Ingatlanfejlesztői oldalról az Ingatlanfejlesztői Kerekasztal Egyesületet (IKE), illetve a Magyar Környezettudatos Építés Egyesületet (HuGBC) említették meg az interjúalanyok. Ezek a szervezetek a szakmai

\footnotetext{
${ }^{69}$ Ezt a kérdéskört a dolgozat a későbbiekben részletesen vizsgálja. A harmadik kutatási egység a ÚMFT keretében megvalósuló településközpont rehabilitációk közül öt beruházás esetében tekinti át, hogy a projekt által létrehozott menedzsment szervezet stratégiai gondolkodású településfejlesztési egységként működik-e a beruházást követően.
} 
érdekképviselet mellett, a szakma presztízsének növelését, a „kontárok” kiszürését is feladatának tekinti. Az egyesületek tagok célja, az egyik megkérdezet elmondása szerint „átlátható, kiszámitható és fenntartható keretek között folytatni az ingatlanfejlesztési tevékenységet”. Államigazgatási oldalról is volt, aki aláhúzta az ingatlanfejlesztőkkel való partnerség fontos szerepét. „Hiba ellenfelet, vagy pláne ellenséget keresni bennük, mivel a fövárosi fejlesztések döntő többségét a rendszerváltást követöen az ingatlanfejlesztő szakma hozta létre”. Más megkérdezett azonban éppen ezt rótta a városvezetés terhére. A megkérdezett tájépítészek szakmai szervezeteik (MÉK Táj- és Kertépítészeti Tagozata, Magyar Tájépítészek Szövetsége) segítségével remélik elsősorban a jogalkotók munkájának eredményesebb befolyásolását. A hatékonyabb érdekérvényesítés és a közös érdekek mentén a szakmák közötti együttmüködés elemei is megjelentek az elmúlt év során. Igaz, ugyanakkor, hogy ennek az együttmüködésének a legfőbb mozgatórugója, a szakmák jelenlegi marginális helyzete, javaslataiknak a negligálása a jogszabály véleményezési folyamatokban. $^{70}$

A lakossággal való partnerség fontossága több interjú során felmerült, mint fontos a település megújítást segítő eszköz. Ingatlan fejlesztői oldalról ennek kapcsán a fejlesztők társadalmi felelősségvállalási tevékenysége került említésre, melyek során szponzori támogatásokkal valamint rendezvényszervezéssel támogatnak helyi, környezettudatosságot erősítő akciókat. Településrendezői oldalról a lakosság aktív bevonását említették lakóhelyük környezetének fejlesztési kérdéseibe illetve a fenntartás feladataiba. Az ilyen projektek kapcsán, a válaszadók véleménye szerint, a lakóhelyhez kötődés erősítése és a környezeti nevelés a fizikai megújítás mellett szintén fontos feladat. A lakosság müemlékvédelmi feladatokba való bevonására a Wekerle telepen indult oktatási programot említette az egyik megkérdezett, ahol a lakókkal tudatosítani igyekezett az önkormányzat otthonaik építészeti értékét. A civil oldal azonban önszerveződő módon is képes közterületi és zöldfelületi témák kapcsán aktivizálódni. Ennek példájára a Kortárs Építészeti Központ közösségi kert kezdeményezését említették páran, mely során a partnerség a civilek és az önkormányzat között civil kezdeményezésre alakult ki. A köztéri arculati projektekkel szemben a szociális rehabilitációs fejlesztések kapcsán említette több megkérdezett, hogy ezek során a lakóközösséggel való együttmüködés lényegesen nagyobb hangsúlyt kap, szemben a településközpont megújítási programokkal, ahol a társadalmi részvételt inkább csak kipipálandó

\footnotetext{
${ }^{70}$ A jogszabályalkotás alakításának aktuális kudarcélményét az egyik megkérdezett az Országos Építésügyi Fórum keretében zajló „,látszat egyeztetések” kapcsán mutatta be. A z 3/2011. (II.23.) BM rendelet által létrehozott építésügyi mely „az építésügyi szakmai és civil érdekképviseletek és az építésügyben érdekelt kormányzati szervek közötti együttmüködés és párbeszéd erösítése, az épített környezet értékeinek és minöségének védelme, színvonalának emelése, az építésügy helyzetét kedvezőtlenül befolyásoló folyamatok megállítása, visszafordítása „, céljából alakult öt munkacsoportban végez a jogalkotást segítő szakmai egyeztetést. A MÉK és az IKE is jelentős energiákat fordított a jogszabályok véleményezésére és javaslatok megfogalmazásába, melyeket az OTÉK javasolt módosítása kapcsán a válaszadó beszámolója szerint (2012-01-27) gyakorlatilag figyelmen kívül hagyott a jogalkotó.
} 
feladatként értelmezi. A lakosság bevonásával kapcsolatban fenntartások is megfogalmazódtak. Az érintettek közönye, konszenzus kialakításának nehézsége volt az, amit a leginkább gyakori akadályként elhangzott. Ez a kettő együttesen mutatkozik meg a vezetőkben és a választókban egyaránt rögzült paternalista személetmódban. Vagyis abban, hogy a lakosok még a kisebb, a helyi közösséghez szorosan kötődő problémák megoldását az önkormányzattól várják, nem tekintik feladatuknak az ebben való aktív közremüködést. Volt riportalany, aki ezt úgy foglalta össze, hogy „ez az ország Kádár népe”. Az ehhez a szemlélethez kötődő, pozitivista tervezői attitüd a közterületek megújítását, mint müszaki problémát írta le, ahol a jól képzett szakember a megoldás kulcsa. „Az orvos sem kérdezi meg a pácienstöl, hogy hogyan mütse”, hangzott el szabadtértervezői oldalról. 


\section{M3. számú melléklet: A szabadtérfejlesztési stratégiákban megfogalmazott projektek}

\section{ProVerde!}

\begin{tabular}{|c|c|c|c|c|c|c|}
\hline & Sor-szám & $\begin{array}{l}\text { Beavatkozás } \\
\text { típus }\end{array}$ & $\begin{array}{c}\text { Nem } \\
\text { valósult } \\
\text { meg }\end{array}$ & $\begin{array}{l}\text { Részen } \\
\text { megvalósu } \\
\text { lt }\end{array}$ & $\begin{array}{c}\text { Folyamatb } \\
\text { an }\end{array}$ & $\begin{array}{c}\text { Megvalósu } \\
\text { lt }\end{array}$ \\
\hline 1 & „Ki a szabadba” - kampány & partnerség & 1 & & & \\
\hline 2 & $\begin{array}{l}\text { A zöldfelület tudatosságot erősítő } \\
\text { kommunikációs projekt }\end{array}$ & $\begin{array}{l}\text { kapacitásfejleszté } \\
\text { s }\end{array}$ & 1 & & & \\
\hline 3 & Pro Verde Budapest díj létrehozása & $\begin{array}{l}\text { kapacitásfejleszté } \\
\mathrm{s}\end{array}$ & 1 & & & \\
\hline 4 & Sótlanítási kampány & fenntartás & & & & 1 \\
\hline 5 & Fórum a zöldért & partnerség & 1 & & & \\
\hline 6 & Budapesti táj-építészeti fórum: & $\begin{array}{l}\text { kapacitásfejleszté } \\
\text { s }\end{array}$ & 1 & & & \\
\hline 7 & \begin{tabular}{|l} 
Zöldfelületi érdekérvényesítés \\
erősítése
\end{tabular} & partnerség & 1 & & & \\
\hline 8 & $\begin{array}{l}\text { Az ökologikus zöldfelület fenntartás } \\
\text { népszerüsítése }\end{array}$ & $\begin{array}{l}\text { kapacitásfejleszté } \\
\mathrm{s}\end{array}$ & 1 & & & \\
\hline 9 & $\begin{array}{l}\text { A Zöldfelület fenntartás } \\
\text { színvonalának emelése }\end{array}$ & fenntartás & & 1 & & \\
\hline 10 & Zöldterületek arculatformálása & alakítás & 1 & & & \\
\hline 11 & Park(jár)őr-szolgálat & szabályozás & 1 & & & \\
\hline 12 & $\begin{array}{l}\text { Rendezvényterek kijelölése, } \\
\text { fejlesztése }\end{array}$ & beruházás & 1 & & & \\
\hline 13 & $\begin{array}{l}\text { Az alulhasznosított városi parkok } \\
\text { revitalizációja }\end{array}$ & beruházás & 1 & & & \\
\hline 14 & $\begin{array}{l}\text { Az egyedi zöldterületek } \\
\text { szolgáltatásainak korszerüsítése }\end{array}$ & beruházás & & 1 & & \\
\hline 15 & „Görzenálok” kialakítása & beruházás & & 1 & & \\
\hline 16 & $\begin{array}{l}\text { Vizek megjelenítése a zöld- és } \\
\text { közterületeken }\end{array}$ & beruházás & & 1 & & \\
\hline 17 & \begin{tabular}{|l} 
Kutyatartás zöldfelületi \\
vonatkozásainak kezelése
\end{tabular} & szabályozás & & 1 & & \\
\hline 18 & Kerítés-program & beruházás & 1 & & & \\
\hline 19 & $\begin{array}{l}\text { A helyi közösségek bevonása a } \\
\text { zöldfelület fenntartásba }\end{array}$ & partnerség & & 1 & & \\
\hline 20 & „ZZöldvállalkozások” program & partnerség & 1 & & & \\
\hline 23 & $\begin{array}{l}\text { Zöldfelületi alap forrásainak növelése } \\
\text { a kompenzációs célprogram } \\
\text { felhasználásával }\end{array}$ & gazd & 1 & & & \\
\hline 24 & $\begin{array}{l}\text { Biológiai aktivitás kompenzációs } \\
\text { program kidolgozása, kompenzációs } \\
\text { stratégia bevezetése }\end{array}$ & szabályozás & & 1 & & \\
\hline 25 & $\begin{array}{l}\text { BVKSZ zöldfelületi minimumainak } \\
\text { felülvizsgálata }\end{array}$ & szabályozás & 1 & & & \\
\hline 26 & $\begin{array}{l}\text { Zöldterületi normatíva rendszerének } \\
\text { kidolgozása }\end{array}$ & szabályozás & 1 & & & \\
\hline 27 & $\begin{array}{l}\text { Zöldfelületi értékmutatók } \\
\text { egységesítése }\end{array}$ & $\begin{array}{l}\text { kapacitásfejleszté } \\
\mathrm{s}\end{array}$ & & 1 & & \\
\hline 28 & $\begin{array}{l}\text { Beruházást követő fenntartási } \\
\text { kötelezettség }\end{array}$ & szabályozás & 1 & & & \\
\hline 29 & $\begin{array}{l}\text { Az ÉTV kompenzációs megoldásokat } \\
\text { lehetővé tevő felülvizsgálata: }\end{array}$ & szabályozás & 1 & & & \\
\hline 30 & Adószabályozás felülvizsgálata & szabályozás & 1 & & & \\
\hline 33 & Humánerőforrás fejlesztés & gazd & 1 & & & \\
\hline
\end{tabular}


DOI: 10.14267/phd.2014012

Gábor Péter: Városi területek megújítása - különös tekintettel a szabadterekre

\begin{tabular}{|c|c|c|c|c|c|c|}
\hline 34 & $\begin{array}{l}\begin{array}{l}\text { A zöldfelületi alap tovább fejlesztése } \\
\text { (tematizálása) }\end{array} \\
\end{array}$ & gazd & & 1 & & \\
\hline 35 & $\begin{array}{l}\text { A tájépítészeti feladatok } \\
\text { közigazgatási rangjának emelése }\end{array}$ & $\begin{array}{l}\text { kapacitásfejleszté } \\
\text { s }\end{array}$ & 1 & & & \\
\hline 36 & Szakigazgatási fórum működtetése & $\begin{array}{l}\text { kapacitásfejleszté } \\
\text { s }\end{array}$ & 1 & & & \\
\hline 37 & $\begin{array}{l}\text { Elővásárlási pénzalap létrehozása } \\
\text { zöldterületek fejlesztéséhez }\end{array}$ & gazd & 1 & & & \\
\hline 38 & $\begin{array}{l}\text { Közterület használati díj zöldfelületi } \\
\text { komponense }\end{array}$ & szabályozás & 1 & & & \\
\hline 39 & $\begin{array}{l}\text { Parkolási díjak zöldfelületi } \\
\text { komponense }\end{array}$ & szabályozás & 1 & & & \\
\hline 40 & $\begin{array}{l}\text { Önkormányzatok közötti } \\
\text { kompenzáció }\end{array}$ & partnerség & 1 & & & \\
\hline & & & 1 & & & \\
\hline 41 & \begin{tabular}{|l} 
Zöldfelület fejlesztési, zöldfelület \\
védelmi akcióterv kidolgozása
\end{tabular} & alakítás & & & & 1 \\
\hline 42 & $\begin{array}{l}\text { Erdőfejlesztési programterv } \\
\text { kidolgozása }\end{array}$ & alakítás & & 1 & & \\
\hline 43 & $\begin{array}{l}\text { Fasor-felújítási programterv } \\
\text { ütemezése }\end{array}$ & alakítás & 1 & & & \\
\hline 44 & $\begin{array}{l}\text { Kiemelt közparkok üzemeltetési } \\
\text { feltételeinek javítása }\end{array}$ & fenntartás & 1 & & & \\
\hline 45 & Új városi parkok létesítése & beruházás & 1 & & & \\
\hline 46 & $\begin{array}{l}\text { Természetvédelmi területek } \\
\text { rekreációs terhelésének } \\
\text { differenciálása }\end{array}$ & szabályozás & 1 & & & \\
\hline 47 & Parkerdő fejlesztés & beruházás & & 1 & & \\
\hline 48 & $\begin{array}{l}\text { Duna-menti promenád (Zöld Duna) } \\
\text { program }\end{array}$ & beruházás & & 1 & & \\
\hline 49 & $\begin{array}{l}\text { Patak revitalizációs programok } \\
\text { rendszerbe szervezése }\end{array}$ & alakítás & 1 & & & \\
\hline 50 & Zöldgyürü program & alakítás & 1 & & & \\
\hline 51 & $\begin{array}{l}\text { Külső területek zöldterületeinek } \\
\text { minőségi javításának támogatása }\end{array}$ & beruházás & & 1 & & \\
\hline 52 & $\begin{array}{l}\text { Újszerü zöldfelületek kialakításának } \\
\text { programja }\end{array}$ & beruházás & 1 & & & \\
\hline 53 & $\begin{array}{l}\text { Zöldterületi beruházások a } \\
\text { rozsdaövezetben }\end{array}$ & beruházás & & & 1 & \\
\hline 54 & $\begin{array}{l}\text { Az új gyalogosövezetek zöldfelületi } \\
\text { fejlesztése }\end{array}$ & beruházás & 1 & & & \\
\hline 55 & $\begin{array}{l}\text { A zöldterület hiányos területek } \\
\text { zöldterületi fejlesztése }\end{array}$ & beruházás & 1 & & & \\
\hline 56 & $\begin{array}{l}\text { Jó példák gyüjteményének } \\
\text { létrehozása }\end{array}$ & $\begin{array}{l}\text { kapacitásfejleszté } \\
\text { s }\end{array}$ & & & 1 & \\
\hline 57 & Zöldfelületi kataszter aktualizálása & $\begin{array}{l}\text { kapacitásfejleszté } \\
\text { s }\end{array}$ & 1 & & & \\
\hline 58 & $\begin{array}{l}\text { A városi közparkok rekreációs } \\
\text { besorolása }\end{array}$ & szabályozás & 1 & & & \\
\hline 59 & Zöldfelületi sikerek projekt & $\begin{array}{l}\text { kapacitásfejleszté } \\
\mathrm{s}\end{array}$ & 1 & & & \\
\hline 60 & A zöldfelületi rendszer monitorozása & $\begin{array}{l}\text { kapacitásfejleszté } \\
\text { s }\end{array}$ & 1 & & & \\
\hline 61 & $\begin{array}{l}\text { Zöldfelület fejlesztés, érdek- } \\
\text { ellenérdek }\end{array}$ & szabályozás & 1 & & & \\
\hline 62 & Zöldfelület üzemeltetési hatékonyság & fenntartás & 1 & & & \\
\hline
\end{tabular}




\section{Margitsziget Stratégia}

\begin{tabular}{|c|c|c|c|c|c|c|c|c|}
\hline No. & $\mathbf{S S z}$ & Projekt név & $\begin{array}{l}\text { Beavatkozá } \\
\text { s típus }\end{array}$ & $\begin{array}{l}\text { Margitsz } \\
\text { iget } 2013\end{array}$ & $\begin{array}{c}\text { Nem } \\
\text { valósult } \\
\text { meg }\end{array}$ & $\begin{array}{c}\text { Részen } \\
\text { megvalós } \\
\text { ult } \\
\end{array}$ & $\begin{array}{l}\text { Folyama } \\
\text { tban }\end{array}$ & $\begin{array}{l}\text { Megvaló } \\
\text { sult }\end{array}$ \\
\hline 1 & 111 & $\begin{array}{l}\text { Palatinus strand menti védő } \\
\text { zöldsáv felújítása }\end{array}$ & fenntartás & $4 p$ & 1 & & & \\
\hline 2 & 112 & $\begin{array}{l}\text { Faállomány felmérése, } \\
\text { balesetveszélyes fák cseréje }\end{array}$ & fenntartás & $4 p$ & & & 1 & \\
\hline 3 & 113 & $\begin{array}{l}\text { Növényalkalmazási koncepció } \\
\text { készítése a klímaváltozás } \\
\text { mérséklésére }\end{array}$ & alakítás & 40 & 1 & & & \\
\hline 4 & 114 & Fatelepítés & beruházás & $4 p$ & & & 1 & \\
\hline 5 & 115 & $\begin{array}{l}\text { Túlburjánzó, elöregedő } \\
\text { cserjeállomány megújítása }\end{array}$ & fenntartás & $4 p$ & & 1 & & \\
\hline 6 & 121 & $\begin{array}{l}\text { Madáritatók és etetők } \\
\text { kihelyezése, fenntartása }\end{array}$ & beruházás & & 1 & & & \\
\hline 7 & 122 & $\begin{array}{l}\text { Virágoskert menti kiserdő } \\
\text { felújítása }\end{array}$ & fenntartás & $4 p$ & 1 & & & \\
\hline 8 & 131 & $\begin{array}{l}\text { Hulladékgyűjtők helyének, } \\
\text { méretének, formájának rendezése }\end{array}$ & alakítás & $4 \mathrm{e}$ & 1 & & & \\
\hline 9 & 132 & $\begin{array}{l}\text { Szelektív gyüjtés, pillepalack } \\
\text { tömörítők kihelyezése }\end{array}$ & beruházás & & 1 & & & \\
\hline 10 & 133 & $\begin{array}{l}\text { Rendezvények idején intenzívebb } \\
\text { közterület takarítás }\end{array}$ & fenntartás & & & & & 1 \\
\hline 11 & 211 & $\begin{array}{l}\text { Árvízvédelmi terv készítése az } \\
\text { árvízi károk megelőzésére }\end{array}$ & alakítás & & & 1 & & \\
\hline 12 & 212 & $\begin{array}{l}\text { Mobil védőmü biztosítása a } \\
\text { védekezéshez }\end{array}$ & beruházás & & 1 & & & \\
\hline 13 & 311 & $\begin{array}{l}\text { Sziklakert (Japán kert) } \\
\text { rekonstrukciója }\end{array}$ & beruházás & $4 g$ & 1 & & & \\
\hline 14 & 312 & Rózsakert felújítása & beruházás & $\begin{array}{c}\text { megvalós } \\
\text { ult }\end{array}$ & & & & 1 \\
\hline 15 & 313 & Virágoskert felújítása & beruházás & $4 p$ & 1 & & & \\
\hline 16 & 314 & Szanatórium kert rekonstrukciója & beruházás & & 1 & & & \\
\hline 17 & 321 & Tematikus kertek körülkerítése & beruházás & $4 p$ & 1 & & & \\
\hline 18 & 322 & Játszóterek körülkerítése & beruházás & $4 p$ & 1 & & & \\
\hline 19 & 323 & Régészeti emlékek körülkerítése & beruházás & $4 p$ & 1 & & & \\
\hline 20 & 331 & $\begin{array}{l}\text { Öntözőhálózat gerincvezeték } \\
\text { felújítása, az ivóvíz és a parki } \\
\text { öntözőhálózat szétválasztása }\end{array}$ & beruházás & $4 n$ & 1 & & & \\
\hline 21 & 332 & $\begin{array}{l}\text { Öntözőhálózat fejlesztése } \\
\text { (automata öntözőhálózat) }\end{array}$ & beruházás & & 1 & & & \\
\hline 22 & 333 & $\begin{array}{l}\text { Saját kút kialakítása vagy Duna } \\
\text { vízzel történő öntözés kiépítése }\end{array}$ & beruházás & $4 n$ & 1 & & & \\
\hline 23 & 341 & $\begin{array}{l}\text { Virágállomány fenntartása, } \\
\text { hiányok pótlása }\end{array}$ & fenntartás & & & & 1 & \\
\hline 24 & 342 & $\begin{array}{l}\text { A Margitsziget értéken való } \\
\text { nyilvántartása (kataszter felújítás } \\
\text { a növényállományról, az épített } \\
\text { értékekről) }\end{array}$ & $\begin{array}{l}\text { kapacitás } \\
\text { fejl }\end{array}$ & 40 & 1 & & & \\
\hline 25 & 343 & $\begin{array}{l}\text { Póló-pálya menti egynyári és } \\
\text { évelő bemutatókert felújítása }\end{array}$ & beruházás & & 1 & & & \\
\hline
\end{tabular}


DOI: $10.14267 /$ phd.2014012

\begin{tabular}{|c|c|c|c|c|c|c|c|c|}
\hline 26 & 344 & Müvész-sétány felújítása & beruházás & & 1 & & & \\
\hline 27 & 345 & $\begin{array}{l}\text { Fölösleges burkolatok bontása, } \\
\text { zöldfelület növelése }\end{array}$ & beruházás & & 1 & & & \\
\hline 28 & 346 & $\begin{array}{l}\text { Gyepfelületek folyamatos } \\
\text { fenntartása, megújítása }\end{array}$ & fenntartás & $4 p$ & & & 1 & \\
\hline 29 & 351 & $\begin{array}{l}\text { Nagy szökőkút környezetének } \\
\text { rendezése }\end{array}$ & beruházás & & & & & 1 \\
\hline 30 & 352 & $\begin{array}{l}\text { Európa-ház, Póló pálya közötti } \\
\text { gyalogút kialakítása }\end{array}$ & beruházás & & 1 & & & \\
\hline 31 & 353 & $\begin{array}{l}\text { Gyalogjárda létesítés az Árpád } \\
\text { híd margitszigeti szárnyhíd } \\
\text { nyugati oldalán }\end{array}$ & beruházás & & 1 & & & \\
\hline 32 & 354 & $\begin{array}{l}\text { Virágoskert és Vadaspark közötti } \\
\text { burkolat felújítás }\end{array}$ & fenntartás & & 1 & & & \\
\hline 33 & 355 & $\begin{array}{l}\text { Gyalogos, kerékpáros burkolatok } \\
\text { differenciált felújítása }\end{array}$ & szabályozás & & 1 & & & \\
\hline 34 & 361 & $\begin{array}{l}\text { Margit-hídi bejáratnál lévő } \\
\text { rézsük stabilizálása }\end{array}$ & beruházás & & 1 & & & \\
\hline 35 & 371 & $\begin{array}{l}\text { Meglévő vízfelületek } \\
\text { (vízmedencék, csobogók) } \\
\text { rekonstrukciója }\end{array}$ & beruházás & $4 \mathrm{f}$ & & 1 & & \\
\hline 36 & 372 & Vízfelületek számának növelése & beruházás & & 1 & & & \\
\hline 37 & 381 & $\begin{array}{l}\text { Árpád-hídi fogadóterület } \\
\text { rendezése }\end{array}$ & beruházás & & & 1 & & \\
\hline 38 & 382 & $\begin{array}{l}\text { Margit-hídi fogadóterület } \\
\text { közterületi rendezése }\end{array}$ & beruházás & $4 a$ & & & & 1 \\
\hline 39 & 383 & $\begin{array}{l}\text { Hajós Alfréd uszoda } \\
\text { fogadóterének } \\
\text { környezetrendezése }\end{array}$ & beruházás & & 1 & & & \\
\hline 40 & 384 & $\begin{array}{l}\text { Közparki lépcsők, támfalak } \\
\text { egységes dizájn szerinti } \\
\text { ütemezett felújítása }\end{array}$ & alakítás & $4 p$ & 1 & & & \\
\hline 41 & 111 & $\begin{array}{l}\text { Szigeten keletkező szennyvizek } \\
\text { kezelésének megoldása }\end{array}$ & beruházás & $1 \mathrm{a}$ & 1 & & & \\
\hline 42 & 112 & $\begin{array}{l}\text { Ivókutak rákötése a } \\
\text { csatornahálózatra }\end{array}$ & beruházás & 41 & 1 & & & \\
\hline 43 & 121 & $\begin{array}{l}\text { A futókör teljes közvilágításának } \\
\text { biztosítása }\end{array}$ & beruházás & $4 \mathrm{k}$ & & & & 1 \\
\hline 44 & 122 & $\begin{array}{l}\text { A sziget látványosságainak } \\
\text { díszkivilágítása }\end{array}$ & beruházás & $5 a$ & 1 & & & \\
\hline 45 & 123 & $\begin{array}{l}\text { Közparki úthálózat } \\
\text { közvilágításának fejlesztése }\end{array}$ & beruházás & $5 a$ & 1 & & & \\
\hline 46 & 131 & $\begin{array}{l}\text { A parti-szürésű kutak és } \\
\text { védőterületük kijelölése és } \\
\text { védelme }\end{array}$ & szabályozás & & 1 & & & \\
\hline 47 & 132 & $\begin{array}{l}\text { A termál kutak hosszú távú } \\
\text { hasznosítása }\end{array}$ & beruházás & & 1 & & & \\
\hline 48 & 211 & $\begin{array}{l}\text { A Margit-híd rekonstrukcióhoz } \\
\text { kapcsolódók tömegközlekedési } \\
\text { fejlesztés }\end{array}$ & beruházás & & & & & 1 \\
\hline 49 & 212 & $\begin{array}{l}\text { Ráhordó járatok szezonális } \\
\text { sűrítése (május-szeptember) }\end{array}$ & $\begin{array}{l}\text { kapacitás } \\
\text { fejl }\end{array}$ & $1 \mathrm{c}$ & & 1 & & \\
\hline 50 & 213 & $\begin{array}{l}\text { A szigeti belső tömegközlekedés } \\
\text { modernizálása }\end{array}$ & szabályozás & & & 1 & & \\
\hline
\end{tabular}


DOI: $10.14267 /$ phd.2014012

\begin{tabular}{|c|c|c|c|c|c|c|c|c|}
\hline 51 & 214 & $\begin{array}{l}\text { M5-ös metró (észak-déli } \\
\text { gyorsvasút) nyomvonal korrekció }\end{array}$ & beruházás & & 1 & & & \\
\hline 52 & 221 & $\begin{array}{l}\text { A vízi közlekedési járatok } \\
\text { szezonális sűrítése }\end{array}$ & $\begin{array}{l}\text { kapacitás } \\
\text { fejl }\end{array}$ & & & & & 1 \\
\hline 53 & 222 & $\begin{array}{l}\text { A vízik közlekedési jármüvek } \\
\text { korszerüsítése }\end{array}$ & beruházás & & 1 & & & \\
\hline 54 & 223 & $\begin{array}{l}\text { Átszállási kapcsolatok javítása a } \\
\text { szárazföldi és vízi járatok között } \\
\text { (Batthyány-tér) }\end{array}$ & beruházás & $1 d$ & 1 & & & \\
\hline 55 & 311 & $\begin{array}{l}\text { Árpád-híd hídfőjében } \\
\text { teremgarázs kialakítása a felszíni } \\
\text { parkolók kiváltása céljából }\end{array}$ & beruházás & $\begin{array}{l}\text { ellentétes } \\
\text { 1f } \\
\text { parkoló } \\
\text { bövítés }\end{array}$ & 1 & & & \\
\hline 56 & 312 & $\begin{array}{l}\text { Beléptetési rendszer } \\
\text { felülvizsgálata (Árpád híd), } \\
\text { rendszámfelismerô rendszer } \\
\text { kialakítása }\end{array}$ & beruházás & & & & & 1 \\
\hline 57 & 321 & $\begin{array}{l}\text { Pest-Buda emlékmü } \\
\text { körfordulójának rendezése }\end{array}$ & beruházás & & & & & 1 \\
\hline 58 & 322 & Közúti burkolatok felújítása & beruházás & $4 \mathrm{c}$ & 1 & & & \\
\hline 59 & 411 & $\begin{array}{l}\text { Észak-déli közút T40-as } \\
\text { besorolását, vegyes használatát } \\
\text { közúti táblákkal, burkolati } \\
\text { jelekkel szükséges jelezni }\end{array}$ & szabályozás & & 1 & & & \\
\hline 60 & 412 & $\begin{array}{l}\text { Kerékpártárolók létesítése, a } \\
\text { kerékpározás feltételeinek } \\
\text { javítása }\end{array}$ & beruházás & & & & 1 & \\
\hline 61 & 421 & $\begin{array}{l}100 \% \text {-os közterületi } \\
\text { akadálymentesítés (buszmegállók } \\
\text { is egy új busztípus } \\
\text { függvényében) }\end{array}$ & beruházás & & 1 & & & \\
\hline 62 & 431 & $\begin{array}{l}\text { Gyaloghíd létesítése } \\
\text { Újlipótváros, Újlak irányába }\end{array}$ & beruházás & & 1 & & & \\
\hline 63 & 111 & $\begin{array}{l}\text { Kolostor romok } \\
\text { környezetrendezése }\end{array}$ & beruházás & & 1 & & & \\
\hline 64 & 112 & $\begin{array}{l}\text { Ferences és Premontrei } \\
\text { kolostorok feltárása és } \\
\text { bemutatása }\end{array}$ & beruházás & & 1 & & & \\
\hline 65 & 121 & $\begin{array}{l}\text { Szabadtéri Színpad és Víztorony } \\
\text { valamint környezetének } \\
\text { rekonstrukciója }\end{array}$ & beruházás & $4 \mathrm{~h}$ & & & 1 & \\
\hline 66 & 122 & $\begin{array}{l}\text { Önkormányzati tulajdonú } \\
\text { épületek hasznosítása, felújítása } \\
\text { (Sirály Csónakház, Európa Ház) }\end{array}$ & beruházás & $5 \mathrm{i}$ & & 1 & & \\
\hline 67 & 123 & $\begin{array}{l}\text { Leromlott, balesetveszélyes } \\
\text { épületek, építmények bontása } \\
\text { (Margitszigeti Teniszcenturm } \\
\text { lelátók, Palatinus Nyugati front) }\end{array}$ & beruházás & & 1 & & & \\
\hline 68 & 124 & $\begin{array}{l}\text { A Duna part } \\
\text { megközelíthetőségének javítása }\end{array}$ & beruházás & & 1 & & & \\
\hline 69 & 211 & Integrált Margitsziget honlap & $\begin{array}{l}\text { kapacitás } \\
\text { fejl }\end{array}$ & $3 a$ & 1 & & & \\
\hline 70 & 212 & Információs pont létesítése & $\begin{array}{l}\text { kapacitás } \\
\text { fejl }\end{array}$ & $3 a$ & & 1 & & \\
\hline 71 & 213 & $\begin{array}{l}\text { Dendrológiai, egyéb növényzeti } \\
\text { értékek bemutatása, ehhez } \\
\text { kapcsolódó rendezvények, } \\
\text { vezetett séták, táblarendszer }\end{array}$ & $\begin{array}{l}\text { kapacitás } \\
\text { fejl }\end{array}$ & & 1 & & & \\
\hline
\end{tabular}


DOI: 10.14267/phd.2014012

\begin{tabular}{|c|c|c|c|c|c|c|c|c|}
\hline 72 & 214 & $\begin{array}{l}\text { Információs táblarendszer } \\
\text { kialakítása }\end{array}$ & beruházás & & & 1 & & \\
\hline 73 & 221 & $\begin{array}{l}\text { Pavilonok, elárusítóhelyek } \\
\text { egységes, színvonalas } \\
\text { arculatának kialakítása }\end{array}$ & beruházás & $4 d$ & 1 & & & \\
\hline 74 & 222 & $\begin{array}{l}\text { Egységes kültéri bútorcsalád } \\
\text { kialakítása, meglévők cseréje }\end{array}$ & beruházás & $4 \mathrm{e}$ & 1 & & & \\
\hline 75 & 223 & $\begin{array}{l}\text { Az épületfunkciók, épített elemek } \\
\text { és zöldfelületi kialakítás } \\
\text { összehangolása }\end{array}$ & szabályozás & & 1 & & & \\
\hline 76 & 111 & $\begin{array}{l}\text { Nyilvános öltöző kialakítása a } \\
\text { sportolóknak meglévő } \\
\text { építményekben }\end{array}$ & beruházás & & & 1 & & \\
\hline 77 & 113 & $\begin{array}{l}\text { Nyilvános illemhelyek számának } \\
\text { növelése }\end{array}$ & beruházás & & & 1 & & \\
\hline 78 & 121 & Palatinus strand téliesítése & beruházás & $2 \mathrm{a}$ & 1 & & & \\
\hline 79 & 122 & $\begin{array}{l}\text { Teniszstadion felújítása, } \\
\text { közhasználata, Atlétikai Centrum } \\
\text { közhasználatának javítása }\end{array}$ & beruházás & $2 b$ & 1 & & & \\
\hline 80 & 131 & $\begin{array}{l}\text { HM teniszpályák tulajdonának } \\
\text { megszerzése, területének közcélú } \\
\text { hasznosítása }\end{array}$ & beruházás & $2 b$ & 1 & & & \\
\hline 81 & 132 & Játszóterek felújítása, bővítése & beruházás & $4 b, 4 p$ & & & & 1 \\
\hline 82 & 133 & $\begin{array}{l}\text { Sportszer- és játszószer- } \\
\text { kölcsönzők létesítése }\end{array}$ & beruházás & & & 1 & & \\
\hline 83 & 211 & $\begin{array}{l}\text { Napközis tábor időszakos } \\
\text { megnyitása közhasználatra }\end{array}$ & partnerség & & 1 & & & \\
\hline 84 & 212 & $\begin{array}{l}\text { Szabadtéri színpad és Víztorony } \\
\text { intenzívebb hasznosítása }\end{array}$ & $\begin{array}{l}\text { kapacitás } \\
\text { fejl }\end{array}$ & $2 d$ & & & 1 & \\
\hline 85 & 221 & $\begin{array}{l}\text { A sziget múltjához, } \\
\text { romantikájához kötődő } \\
\text { rendezvények, állandó } \\
\text { helytörténeti gyüjtemény }\end{array}$ & $\begin{array}{l}\text { kapacitás } \\
\text { fejl }\end{array}$ & & 1 & & & \\
\hline 86 & 311 & $\begin{array}{l}\text { Ingyenes WiFi rendszer kiépítése } \\
\text { a sziget területén }\end{array}$ & $\begin{array}{l}\text { kapacitás } \\
\text { fejl }\end{array}$ & $3 a$ & 1 & & & \\
\hline 87 & 312 & $\begin{array}{l}\text { Emelt létszámú, zöldfelületekre } \\
\text { kiterjedő feladatokkal rendelkező } \\
\text { margitszigeti közterület } \\
\text { felügyelet }\end{array}$ & szabályozás & & 1 & & & \\
\hline 88 & 313 & $\begin{array}{l}\text { Összvárosi program a } \\
\text { hajléktalanprobléma kezelésére }\end{array}$ & partnerség & & 1 & & & \\
\hline 89 & 314 & $\begin{array}{l}\text { Térfigyelö kamera rendszer } \\
\text { kiépítése }\end{array}$ & & $5 b$ & 1 & & & \\
\hline 90 & & $\begin{array}{l}\text { Éjszakai szolgáltatások } \\
\text { zajszintjének ellenőrzése és } \\
\text { előírások betartása }\end{array}$ & szabályozás & & & 1 & & \\
\hline 91 & 111 & Szabályozási terv készítése & szabályozás & & & & 1 & \\
\hline 92 & 112 & $\begin{array}{l}\text { Egyeztetés a szennyvíztisztítás } \\
\text { hálózati objektumainak } \\
\text { helykijelöléséröl annak } \\
\text { érdekében, hogy a közparki } \\
\text { terület ne csökkenjen }\end{array}$ & partnerség & & 1 & & & \\
\hline 93 & 121 & Történeti kerti védelem & szabályozás & & 1 & & & \\
\hline 94 & 122 & $\begin{array}{l}\text { A világörökségi státusz } \\
\text { kiterjesztése a Margitsziget } \\
\text { egészére }\end{array}$ & szabályozás & & 1 & & & \\
\hline
\end{tabular}




\begin{tabular}{|c|c|c|c|c|c|c|}
\hline 95 & 131 & $\begin{array}{l}\text { Közterületi rendezvények } \\
\text { számának és jellegének és } \\
\text { feltételeinek szabályozása. }\end{array}$ & szabályozás & & & 1 \\
\hline 96 & 132 & Rendezvényarculat szabályozás & szabályozás & 1 & & \\
\hline 97 & 133 & $\begin{array}{l}\text { A fövárosi tulajdonokon kiadott } \\
\text { szolgáltatási engedélyek } \\
\text { felülvizsgálata, }\end{array}$ & szabályozás & 1 & & \\
\hline 98 & 134 & $\begin{array}{l}\text { Fővárosi koncepció a } \\
\text { tulajdonszerzésre, a közterületek } \\
\text { és intézmények hasznosítására, } \\
\text { üzemeltetésre, fenntartására } \\
\text { vonatkozóan. }\end{array}$ & alakítás & 1 & & \\
\hline 99 & 135 & $\begin{array}{l}\text { A Margitsziget közterületi } \\
\text { rendjének egyedi szabályozása, a } \\
\text { területrészek differenciált } \\
\text { használat, a koordinálást végző } \\
\text { gondnokság kijelölése, }\end{array}$ & szabályozás & & 1 & \\
\hline 100 & 136 & $\begin{array}{l}\text { Behajtási engedélyek telken } \\
\text { belüli parkolóhely esetén történő } \\
\text { kiadása }\end{array}$ & szabályozás & 1 & & \\
\hline 1 & 141 & $\begin{array}{l}\text { Fogadj örökbe program, } \\
\text { szponzori támogatások } \\
\text { rendszerének kidolgozása. }\end{array}$ & partnerség & 1 & & \\
\hline 2 & 142 & $\begin{array}{l}\text { Licit rendszer kialakítása a } \\
\text { rendezési jog értékesítéséhez }\end{array}$ & gazd & 1 & & \\
\hline 3 & 143 & $\begin{array}{l}\text { Közterület-használati bevételek } \\
\text { visszacsatolása a fenntartásba }\end{array}$ & gazd & 1 & & \\
\hline 4 & 144 & $\begin{array}{l}\text { A szakmai fenntartási } \\
\text { programnak megfelelő forrás } \\
\text { biztosítása }\end{array}$ & gazd & 1 & & \\
\hline 5 & 211 & $\begin{array}{l}\text { Társadalmi együttmüködési háló } \\
\text { kialakítása }\end{array}$ & partnerség & 1 & & \\
\hline 6 & 212 & $\begin{array}{l}\text { Közbiztossági, közterület } \\
\text { fenntartói együttmüködés } \\
\text { szabályozása }\end{array}$ & szabályozás & 1 & & \\
\hline 7 & 213 & $\begin{array}{l}\text { Egyeztetési kötelezettség } \\
\text { betartatása a közterületi } \\
\text { engedélyek kiadása során a } \\
\text { közterület fenntartójával }\end{array}$ & szabályozás & 1 & & \\
\hline
\end{tabular}




\section{AngyalZöLD}

\begin{tabular}{|c|c|c|c|c|c|c|}
\hline No. & Projekt megnevezés & $\begin{array}{l}\text { Beavatkozá } \\
\text { s típus }\end{array}$ & $\begin{array}{c}\text { Nem } \\
\text { valósult } \\
\text { meg }\end{array}$ & $\begin{array}{c}\text { Részen } \\
\text { megvalós } \\
\text { ult }\end{array}$ & $\begin{array}{c}\text { Folyamat } \\
\text { ban }\end{array}$ & $\begin{array}{l}\text { Megvalós } \\
\text { ult }\end{array}$ \\
\hline 1 & Gyermek tér fejlesztése & beruházás & & & & 1 \\
\hline 2 & Dráva park fejlesztése & beruházás & & & & 1 \\
\hline 3 & Wein János park fejlesztése & beruházás & & & 1 & \\
\hline 4 & Bulcsú park felújítása & beruházás & & & 1 & \\
\hline 5 & Kassák- Lőportár park fejlesztése & beruházás & & & 1 & \\
\hline 6 & Debrecen park zöldfelületi fejlesztése & beruházás & & & & 1 \\
\hline 7 & Béke-tér zöldterületi fejlesztése & beruházás & & & 1 & \\
\hline 8 & Unoka park zöldfelületi fejlesztése & beruházás & & & & 1 \\
\hline 9 & $\begin{array}{l}\text { Új zöldterület kialakítása a „kőtár” } \\
\text { területén }\end{array}$ & beruházás & & & & 1 \\
\hline 10 & Mókus közkert fejlesztése & beruházás & 1 & & & \\
\hline 11 & Közterületi agora program & beruházás & 1 & & & \\
\hline 12 & $\begin{array}{l}\text { Országbíró lakótelep és sétány } \\
\text { közterületi megújitása }\end{array}$ & beruházás & & & & 1 \\
\hline 13 & Béke-Tatai lakótelep felújítása & beruházás & & & 1 & \\
\hline 14 & $\begin{array}{l}\text { Árpád-hídfö lakótelep közterületi } \\
\text { fejlesztése }\end{array}$ & beruházás & & & 1 & \\
\hline 15 & $\begin{array}{l}\text { Vizafogó lakótelep közterületi } \\
\text { felújítatása } \\
\end{array}$ & beruházás & 1 & & & \\
\hline 16 & $\begin{array}{l}\text { Kárpát utcai lakótelep közterületi } \\
\text { fejlesztése }\end{array}$ & beruházás & & & 1 & \\
\hline 17 & $\begin{array}{l}\text { Gidófalvy lakótelep közterületi } \\
\text { fejlesztés }\end{array}$ & beruházás & & & 1 & \\
\hline 18 & Kassák Lajos utcai lakótelep & beruházás & & & 1 & \\
\hline 19 & Tomori utcai lakótelep & beruházás & & & 1 & \\
\hline 20 & $\begin{array}{l}\text { Szobor- Faludi lakótelep zöldterületi } \\
\text { fejlesztése }\end{array}$ & beruházás & & & & 1 \\
\hline 21 & $\begin{array}{l}\text { Tahi-Fiastyúk lakótelep zöldterületi } \\
\text { fejlesztése }\end{array}$ & beruházás & & & 1 & \\
\hline 22 & Bessenyei - Tutaj pihenőpark & beruházás & & & & \\
\hline 23 & $\begin{array}{l}\text { Csángó lakótelep zöldterületi } \\
\text { fejlesztése }\end{array}$ & beruházás & & & 1 & \\
\hline 24 & Gyöngyösi sétány játszótér felújítása & beruházás & & & & 1 \\
\hline 25 & Hajós játszótér felújítása & beruházás & & & & \\
\hline 26 & Futár park játszótéri fejlesztése & beruházás & 1 & & & \\
\hline 27 & Bárka parki játszótér fejlesztése & beruházás & & & & 1 \\
\hline 28 & Baba téri játszótér fejlesztése & beruházás & & & & 1 \\
\hline 29 & Dráva-parki szökőkút létesítése & beruházás & 1 & & & \\
\hline 30 & József Attila téri szökőkút kialakítása & beruházás & & & & 1 \\
\hline 31 & Debrecen parki vízfelület kialakítása & beruházás & & & & 1 \\
\hline 32 & Wahrmann Mór köz & beruházás & & & & 1 \\
\hline 33 & Kárpát utcai szökőkút & beruházás & 1 & & & \\
\hline 34 & Flesch Ármin köz közparki fejlesztése & beruházás & 1 & & & \\
\hline
\end{tabular}




\begin{tabular}{|c|c|c|c|c|c|c|}
\hline 35 & $\begin{array}{l}\text { Önkormányzati beruházásokhoz } \\
\text { kapcsolódó közterületi fejlesztések }\end{array}$ & beruházás & & & 1 & \\
\hline 36 & Margitsziget közparki fejlesztése & beruházás & & & 1 & \\
\hline 37 & Rákos-patak revitalizáció I. & beruházás & & & 1 & \\
\hline 38 & $\begin{array}{l}\text { Viza utcai antifasiszta emlékmü } \\
\text { közparki területe }\end{array}$ & beruházás & 1 & & & \\
\hline 39 & Duna parti zöldfolyosó északi szakasz & beruházás & 1 & & & \\
\hline 40 & Rákos-patak revitalizáció II. & beruházás & 1 & & & \\
\hline 41 & $\begin{array}{l}\text { Önkormányzati beruházásokhoz } \\
\text { kapcsolódó fasortelepítés }\end{array}$ & beruházás & & & 1 & \\
\hline 42 & $\begin{array}{l}\text { Dolmány u. - Babér u. - Meder u. K- } \\
\text { Ny-i zöldsétány }\end{array}$ & beruházás & 1 & & & \\
\hline 43 & Pozsonyi út forgalom-csillapítása & beruházás & & & 1 & \\
\hline 44 & Vizafogó sétány felújítása & beruházás & & & 1 & \\
\hline 45 & $\begin{array}{l}\text { Wahrmann Mór köz sétálóutca } \\
\text { kialakítása }\end{array}$ & beruházás & & & & 1 \\
\hline 46 & Kerületi fasor rekonstrukciók & beruházás & & & 1 & \\
\hline 47 & $\begin{array}{l}\text { Újlipótvárosi virágos kandeláber } \\
\text { program }\end{array}$ & beruházás & & & 1 & \\
\hline 48 & Vizafogó Általános Iskola & fenntartás & 1 & & & \\
\hline 49 & $\begin{array}{l}\text { MIOK Oktatási Központ udvarának } \\
\text { sportudvarrá alakítása }\end{array}$ & fenntartás & & & & 1 \\
\hline 50 & Csupa-Csoda Óvoda udvarfelújítás & fenntartás & & 1 & & \\
\hline 51 & Napsugár Óvoda udvarfelújítás & fenntartás & & & & 1 \\
\hline 52 & $\begin{array}{l}\text { Hegedűs Géza Ált. Iskola } \\
\text { udvarfelújítás }\end{array}$ & fenntartás & & & & 1 \\
\hline 53 & Angyalkert Tagóvoda udvarfelújítás & fenntartás & & & & 1 \\
\hline 54 & Hétszín Tagóvoda udvarfelújítás & fenntartás & & & & 1 \\
\hline 55 & $\begin{array}{l}\text { Varázskarika Tagóvoda } \\
\text { udvarfelújítása }\end{array}$ & fenntartás & & 1 & & \\
\hline 56 & $\begin{array}{l}\text { Eötvös József Általános Iskola } \\
\text { udvarfelújítása }\end{array}$ & fenntartás & & 1 & & \\
\hline 57 & Németh László Gimnázium & fenntartás & 1 & & & \\
\hline 58 & Ady Endre Gimnázium udvarfelújítása & fenntartás & 1 & & & \\
\hline 59 & Vizafogó Tagóvoda udvarfelújítása & fenntartás & & & & 1 \\
\hline 60 & $\begin{array}{l}\text { Hermann Ottó Általános Iskola } \\
\text { udvarfelújítása }\end{array}$ & fenntartás & 1 & & & \\
\hline 61 & Pöttyös Tagóvoda udvarfelújítása & fenntartás & 1 & & & \\
\hline 62 & Családi napközi udvarfelújítása & fenntartás & & & & 1 \\
\hline 63 & $\begin{array}{l}\text { Közparkok, közkertek, lakótelepi } \\
\text { területek fenntartása }\end{array}$ & fenntartás & & & 1 & \\
\hline 64 & $\begin{array}{l}\text { Vonalas zöldfelületi elemek } \\
\text { fenntartása }\end{array}$ & fenntartás & & & 1 & \\
\hline 65 & Intézményudvarok fenntartása & fenntartás & & & 1 & \\
\hline 66 & Virágzó kerület program & fenntartás & & & 1 & \\
\hline 67 & Kerületrészi köztisztasági akciók & fenntartás & & & 1 & \\
\hline
\end{tabular}


DOI: 10.14267/phd.2014012

\begin{tabular}{|c|c|c|c|c|c|c|}
\hline 68 & $\begin{array}{l}\text { Házhoz mentő szelektív } \\
\text { hulladékgyűjtési program }\end{array}$ & fenntartás & & & & 1 \\
\hline 69 & Program a kulturált ebtartásért & partnerség & & & 1 & \\
\hline 70 & Közterületi roncsautó elszállítás & fenntartás & & & & 1 \\
\hline 71 & $\begin{array}{l}\text { Oktatási intézmények ökológiai } \\
\text { lábnyomának csökkentése }\end{array}$ & partnerség & 1 & & & \\
\hline 72 & Közterületi szelektív hulladékgyüjtés & fenntartás & & & & 1 \\
\hline 73 & Lomtalanítás & fenntartás & & & & 1 \\
\hline 74 & Kerületi szökőkút program & beruházás & & & 1 & \\
\hline 75 & $\begin{array}{l}\text { „Füre lépni szabad!” öntözött } \\
\text { zöldterületek növelése }\end{array}$ & beruházás & & & 1 & \\
\hline 76 & $\begin{array}{l}\text { A kerületi fafaj szortimens, a } \\
\text { klímaváltozáshoz való igazítása?? }\end{array}$ & $\begin{array}{l}\text { kapacitásfej } \\
\text { lesztés }\end{array}$ & & & 1 & \\
\hline 77 & $\begin{array}{l}\text { AngyalZÖLD internetes portál } \\
\text { üzemeltetés, fejlesztése }\end{array}$ & $\begin{array}{l}\text { kapacitásfej } \\
\text { lesztés }\end{array}$ & & & 1 & \\
\hline 78 & $\begin{array}{l}\text { Egységes térinformatikai tájékoztató } \\
\text { rendszer kialakítása }\end{array}$ & $\begin{array}{l}\text { kapacitásfej } \\
\text { lesztés }\end{array}$ & & & 1 & \\
\hline 79 & $\begin{array}{l}\text { Lakossági részvétel a közterületek } \\
\text { tervezésében }\end{array}$ & partnerség & & & & 1 \\
\hline 80 & $\begin{array}{l}\text { Lakossági zöldfelület védnökségi } \\
\text { pályázat }\end{array}$ & partnerség & & & 1 & \\
\hline 81 & Lakossági zöldhulladék gyüjtés & partnerség & & & 1 & \\
\hline 82 & Társasház udvar program & partnerség & & & 1 & \\
\hline 83 & Zöldhomlokzat program & partnerség & & & 1 & \\
\hline 84 & Közösségi kertprogram & partnerség & 1 & & & \\
\hline 85 & Önkéntes munka közterületeken & partnerség & & & 1 & \\
\hline 86 & Közterületi szponzoráció, & partnerség & 1 & & & \\
\hline 87 & $\begin{array}{l}\text { Intézménykertek a környezeti } \\
\text { szemléletformálásért }\end{array}$ & partnerség & 1 & & & \\
\hline 88 & Vendéglátó terasz program & partnerség & & & 1 & \\
\hline 89 & $\begin{array}{l}\text { Települési szerződések kötése a } \\
\text { zöldfelületek fejlesztése érdekében }\end{array}$ & szabályozás & & & 1 & \\
\hline 90 & $\begin{array}{l}\text { Újszerű zöldfelületek, létesítésének } \\
\text { ösztönzése a beruházások során }\end{array}$ & szabályozás & & & 1 & \\
\hline 91 & $\begin{array}{l}\text { A zöldfelületi szabályozók } \\
\text { felülvizsgálata }\end{array}$ & szabályozás & 1 & & & \\
\hline 92 & $\begin{array}{l}\text { A fasori sávokon vezetett közmủ } \\
\text { vezetékek problémájának rendezése }\end{array}$ & szabályozás & 1 & & & \\
\hline 93 & $\begin{array}{l}\text { Zöldfelületi prioritások szem előtt } \\
\text { tartása az infrastruktúra fejlesztések } \\
\text { során }\end{array}$ & szabályozás & & 1 & & \\
\hline 94 & A zöldsávok védelme a parkolástól & szabályozás & & 1 & & \\
\hline
\end{tabular}




\section{M4. számú melléklet: A vizsgált KMOP projektek akcióterületei}

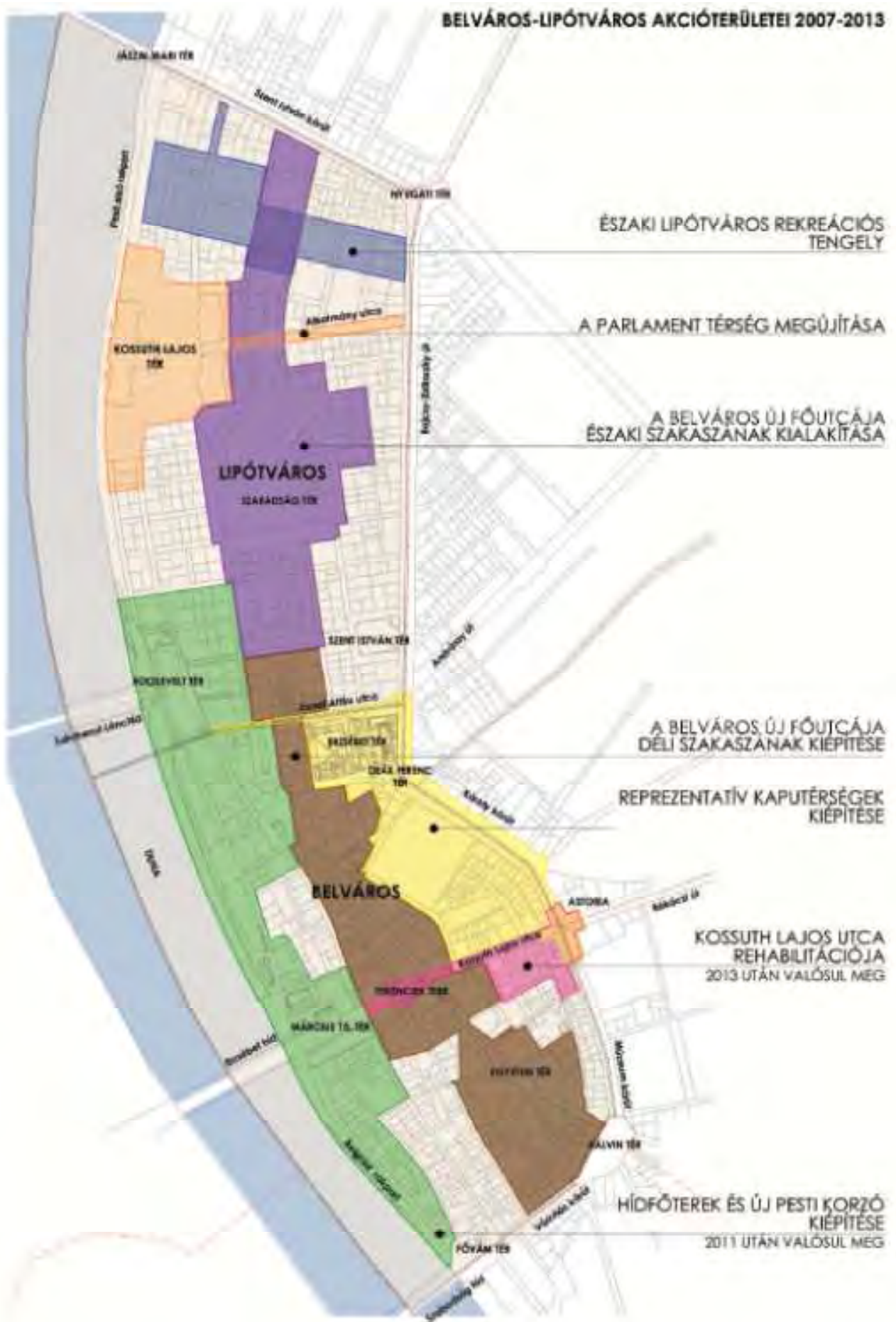

28. ábra: Belváros Lipótváros IVS-ben kijelölt akcióterületei (ATT: 23) 


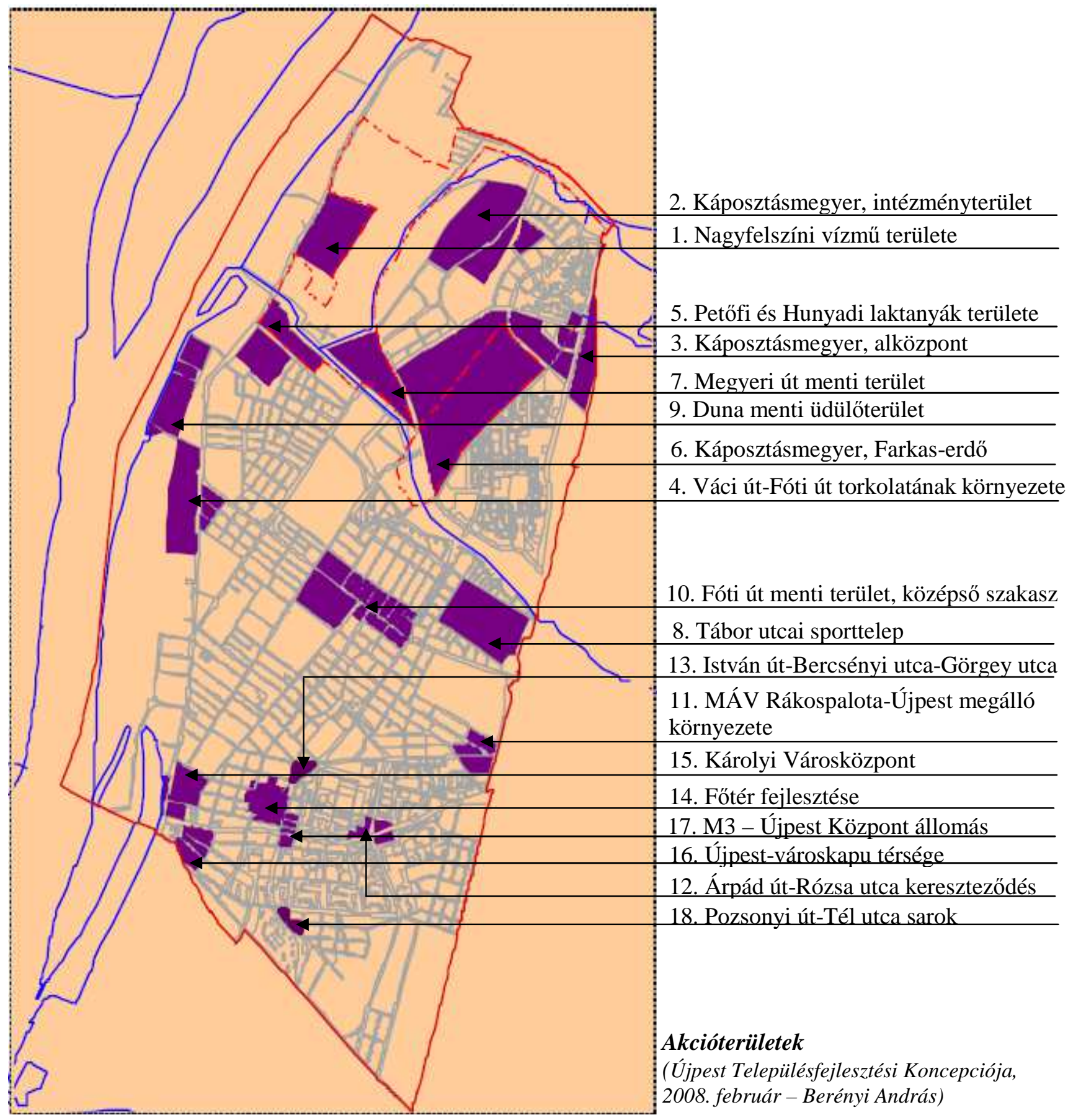

29. ábra: Újpest IVS-ben kijelölt akcióterületei (ATT: 9) 


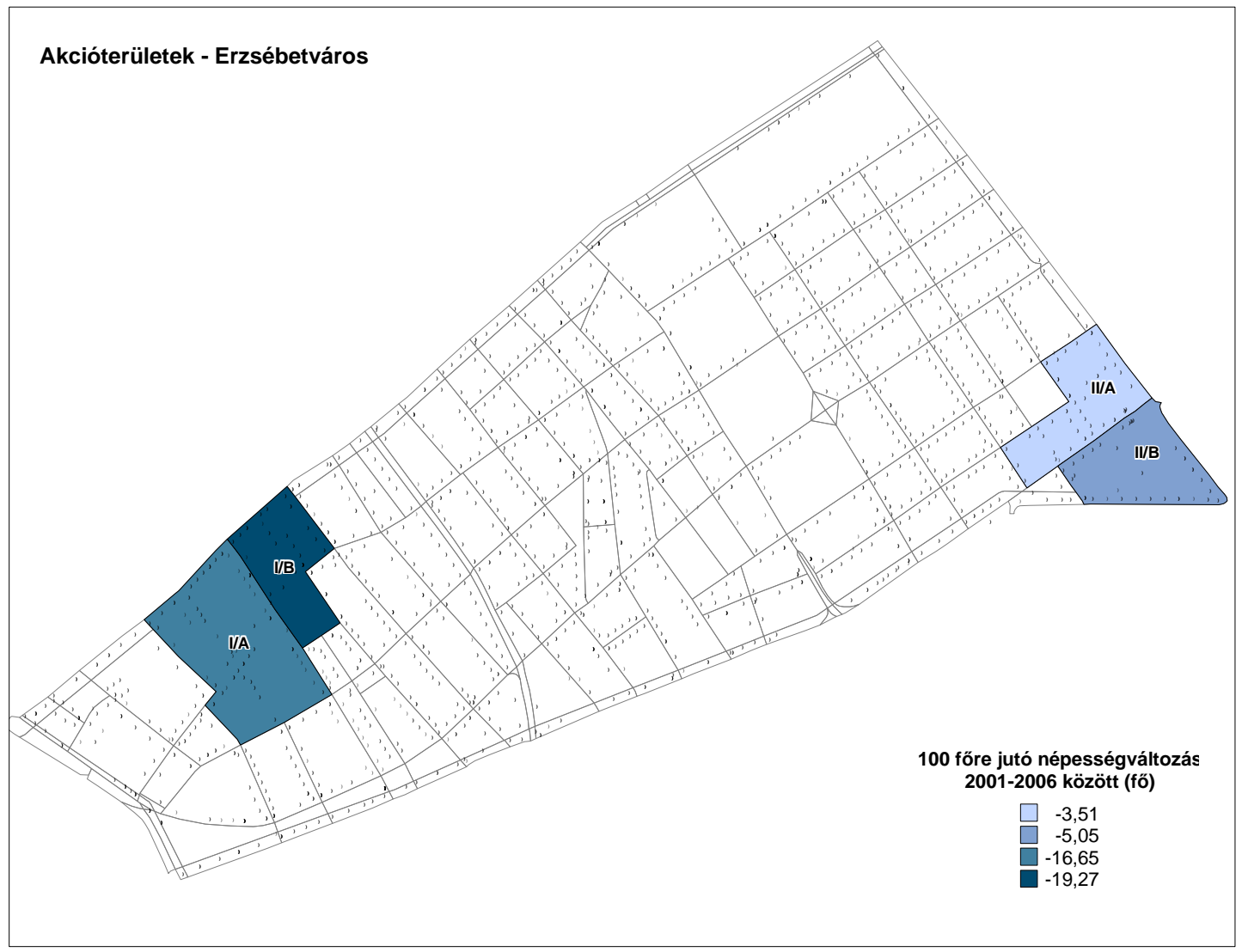

30. ábra: Erzsébetváros IVS-ben kijelölt akcióterületei (IVS: 156)

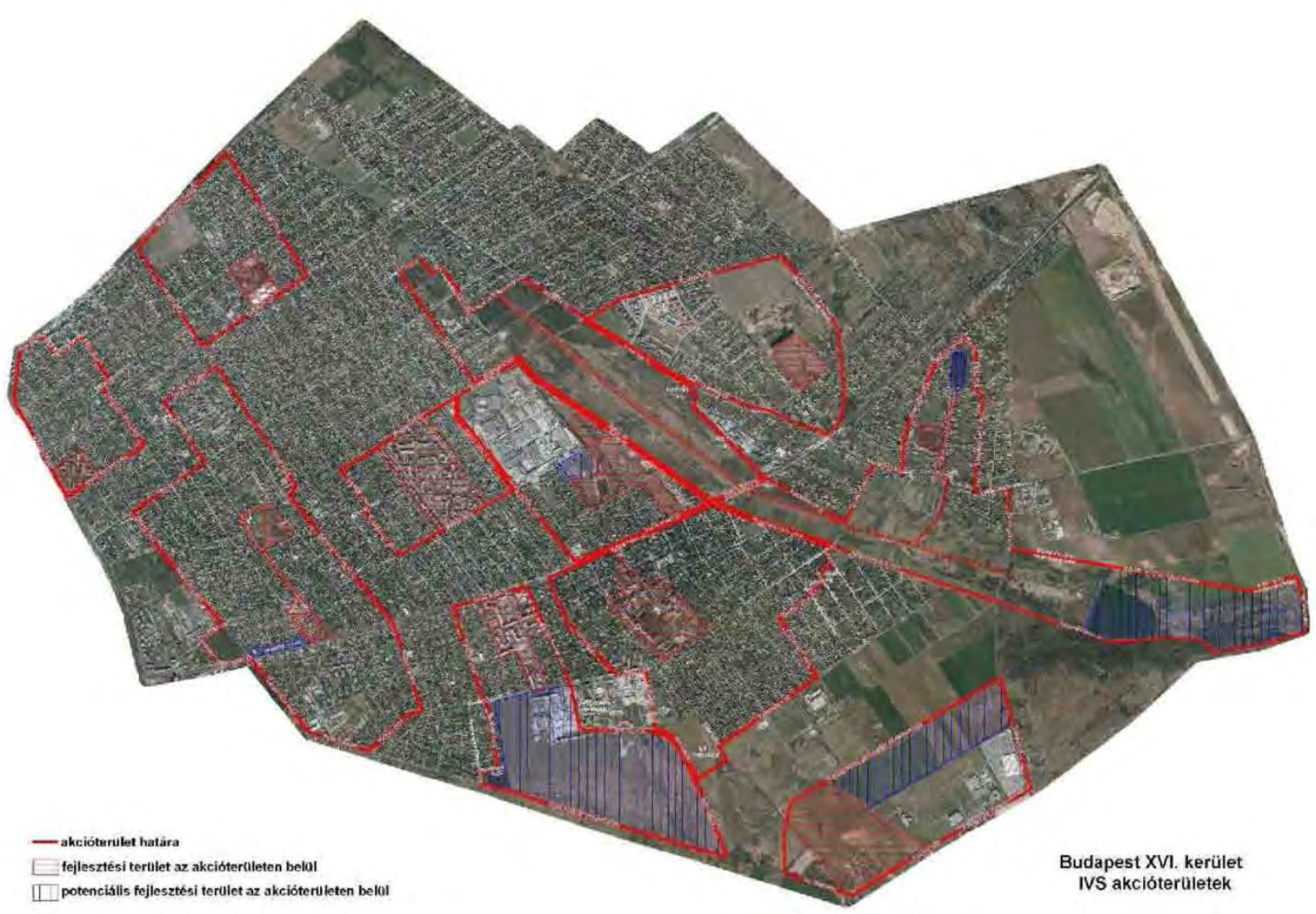

31. ábra: XVI. kerület akcióterületei és fejlesztési területei (ATT: 57) 


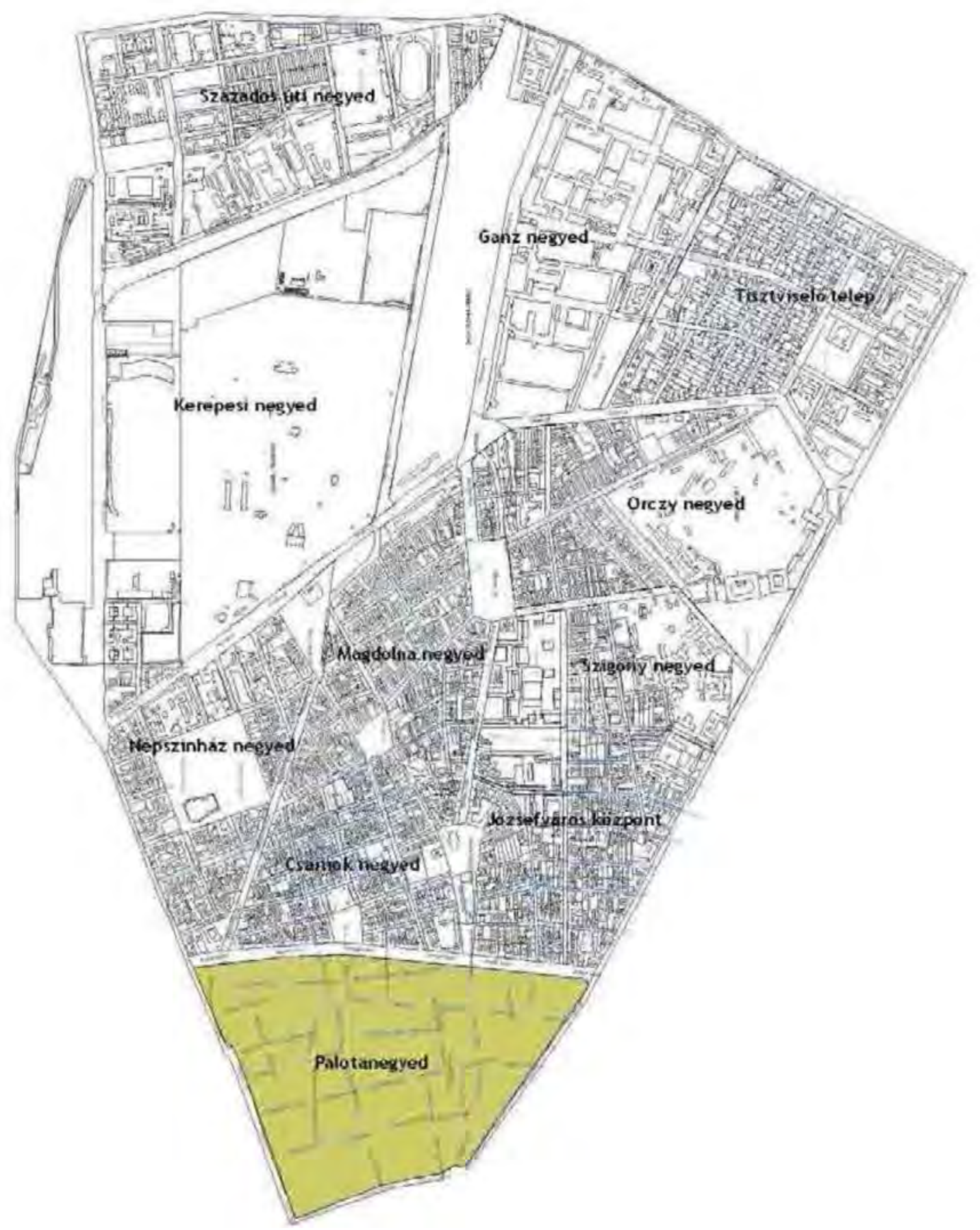

32. ábra: Józsefváros IVS-ben kijelölt városrészei és a Palotanegyed akcióterülete (ATT: 11) 


\section{M5. számú melléklet: Fotómellékletek}

Budapest Szíve Program - Reprezentatív kaputérség kiépítése, I. ütem
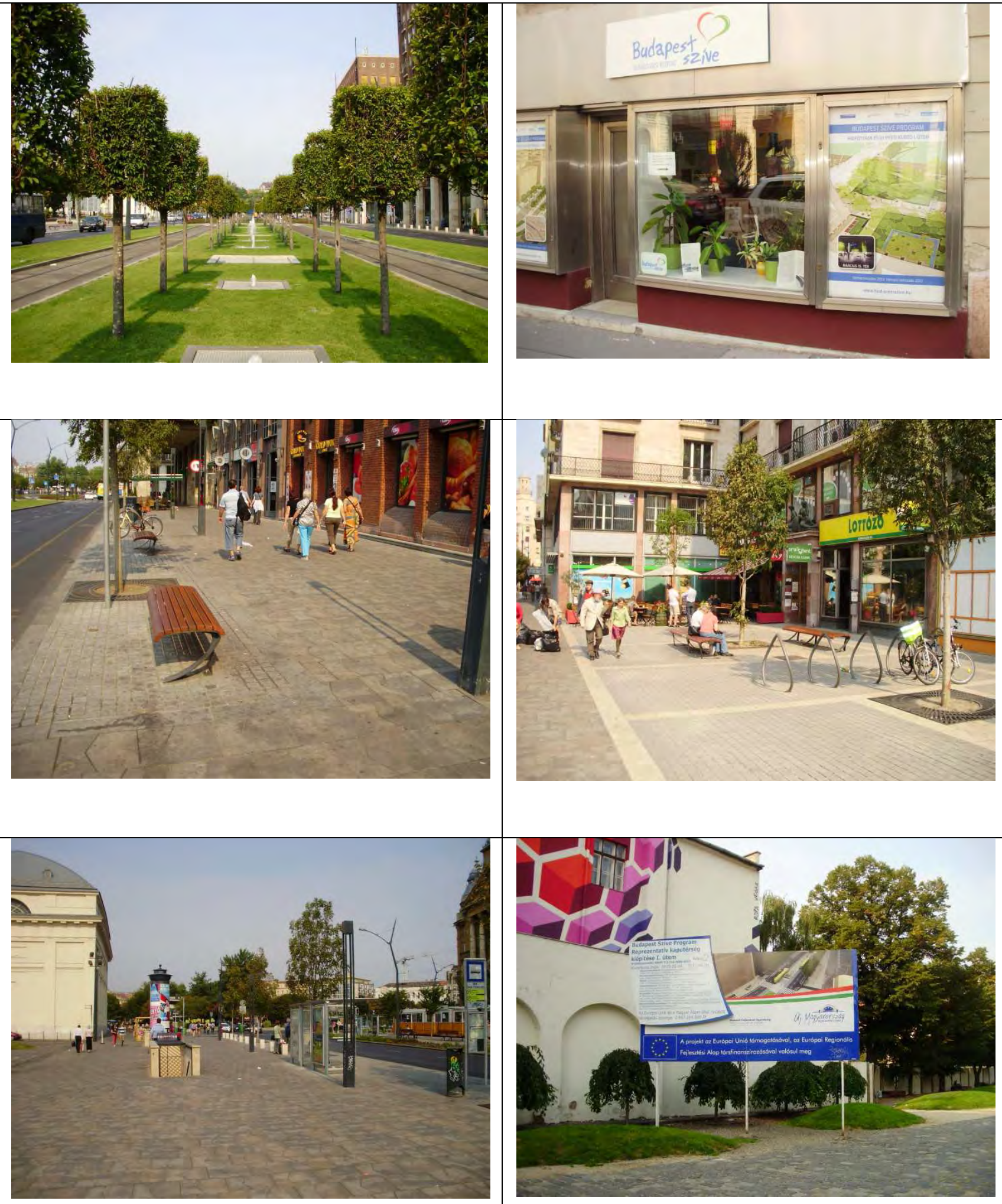
Nagyvárosi jövő - Új Főtér, Újpest
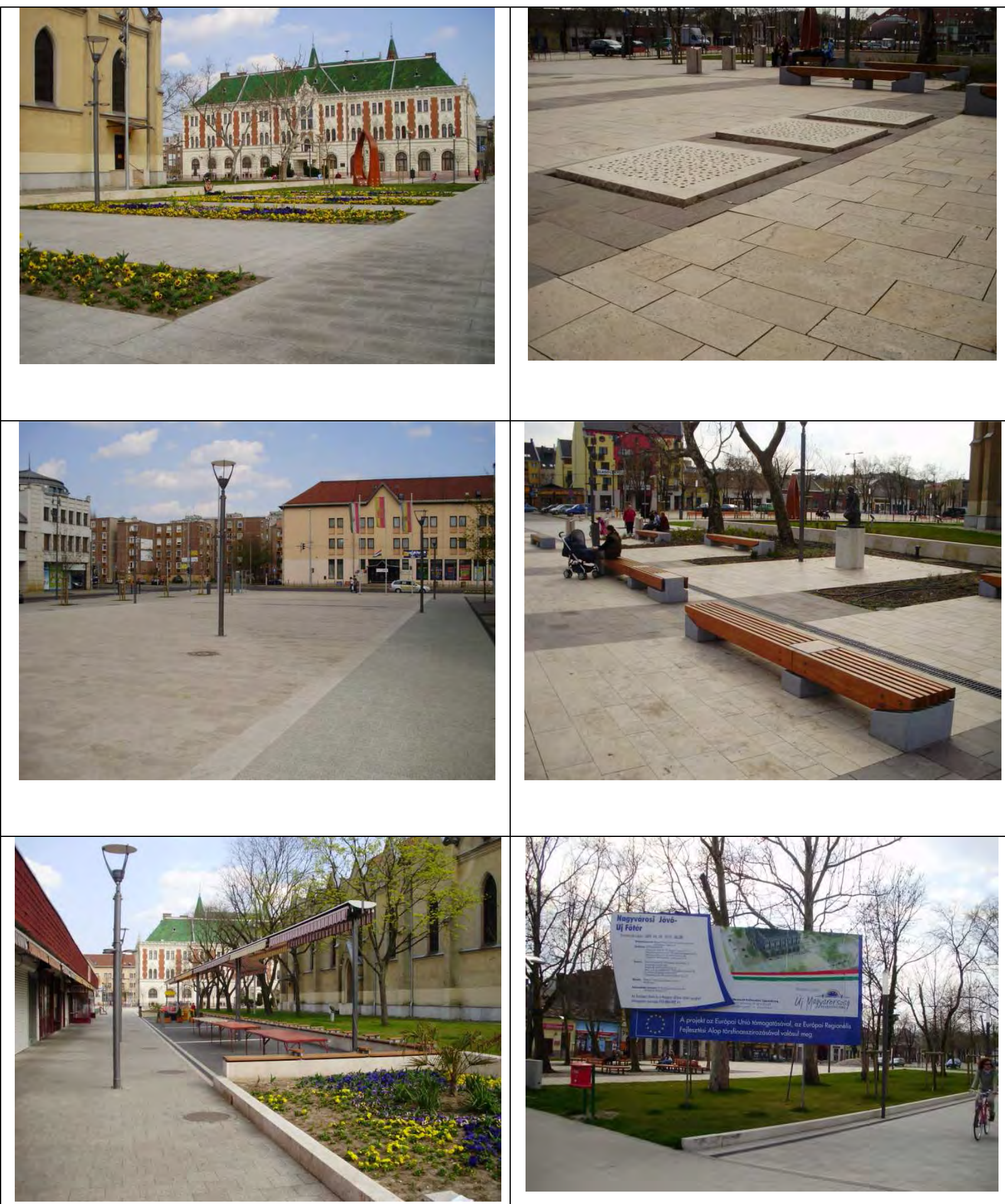
"Kultúra utcája" Budapest, Erzsébetváros funkcióbővítő rehabilitációja
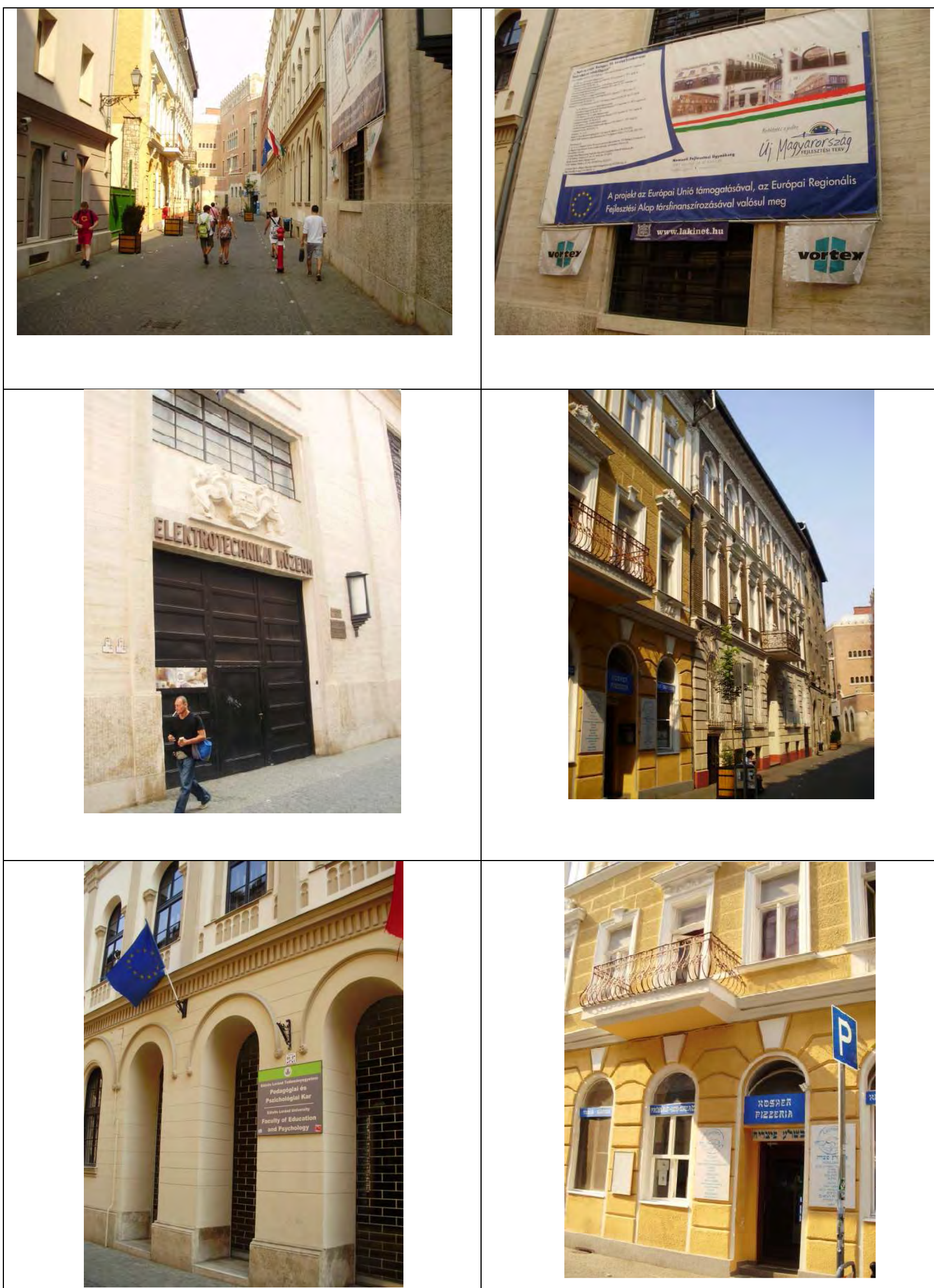
Palotanegyed, Józsefváros
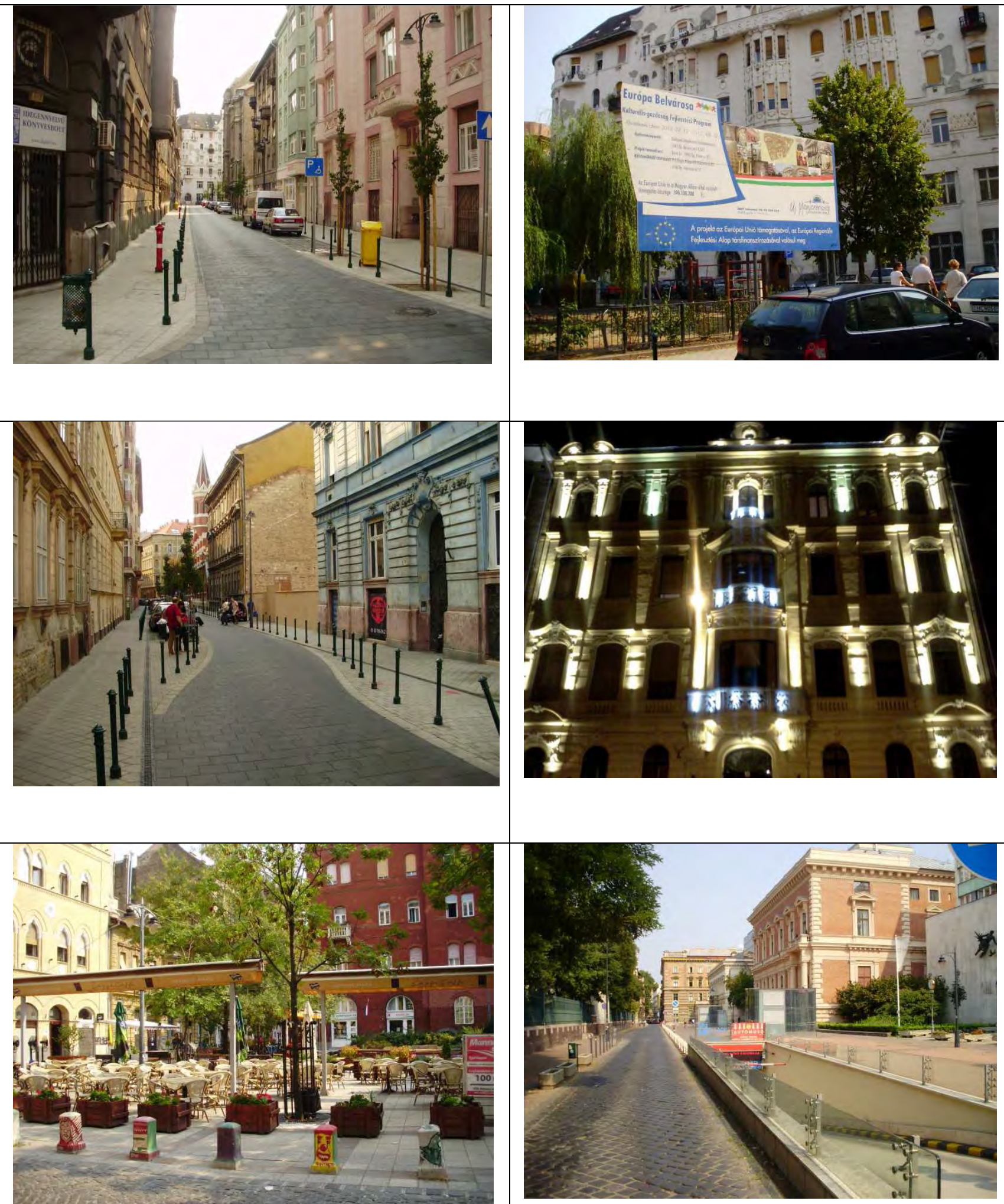
Sashalom városközpont komplex városrehabilitációja
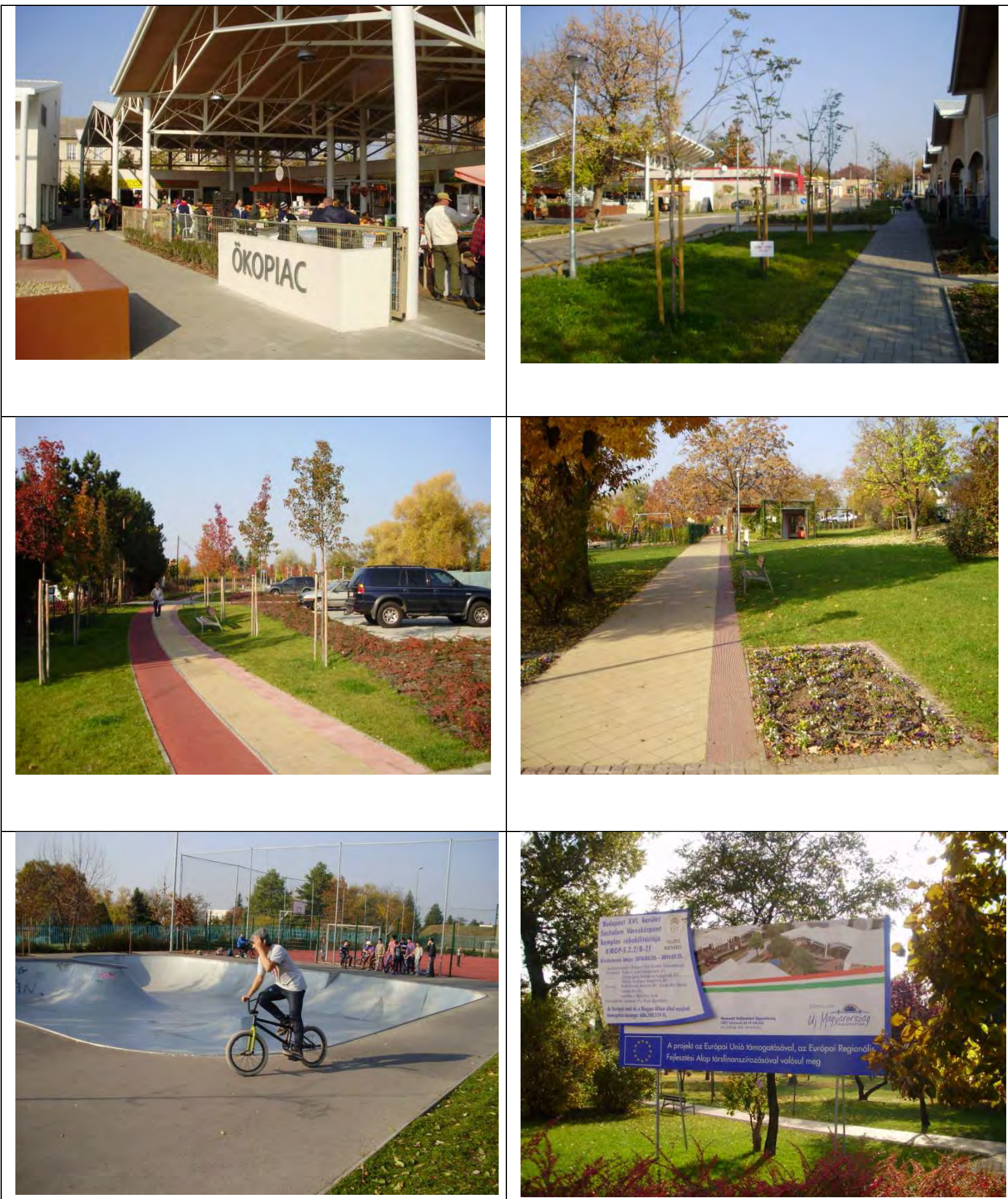
Jegyzetek: 